\title{
FUNDAMENTAL STUDY OF RED MUD BASED FLUXES FOR DESULPHURIZATION AND DEPHOSPHORIZATION OF HOT METAL
}

by

\begin{abstract}
Abdolkarim Danaei
B.Sc. Isfahan University of Technology, Iran, 1985

M.Sc. Sharif University of Technology, Iran, 1993
\end{abstract}

\author{
A dissertation \\ presented to Ryerson University \\ in partial fulfillment of the \\ requirements for the degree of
}

Doctor of Philosophy

in the Program of

Mechanical and Industrial Engineering

Toronto, Ontario, Canada, 2015

(C) Abdolkarim Danaei, 2015 


\section{AUTHOR'S DECLARATION FOR SUBMISSION OF ELECTRONIC DISSERTATION}

I hereby declare that I am the sole author of this dissertation. This is a true copy of the dissertation, including any required final revisions, as accepted by my examiners.

I authorize Ryerson University to lend this dissertation to other institutions or individuals for the purpose of scholarly research.

I further authorize Ryerson University to reproduce this dissertation by photocopying or by other means, in total or in part, at the request of other institutions or individuals for the purpose of scholarly research.

I understand that my dissertation may be made electronically available to the public. 


\begin{abstract}
FUNDAMENTAL STUDY OF RED MUD BASED FLUXES FOR DESULPHURIZATION AND DEPHOSPHORIZATION OF HOT METAL
\end{abstract}

\author{
Doctor of Philosophy, 2015
}

Abdolkarim Danaei

B.Sc. Isfahan University of Technology, Iran

M.Sc. Sharif University of Technology, Iran

Mechanical and Industrial Engineering

Ryerson University

Bauxite residue, also known as red mud, is generated during alumina production and is an abundant industrial waste material. Continuously increasing environmental concerns, together with scarcity of traditional mineral resources, have created a thrust to re-use the material. Red mud contains significant amounts of iron oxide and sodium hydroxide, hence a highly basic $(\mathrm{pH}>10)$ slurry. In this research, the use of red mud as starting material for preparation of iron refining fluxes was evaluated.

Red mud based fluxes and hot metal were equilibrated in graphite crucibles at the temperature range of $1300{ }^{\circ} \mathrm{C}$ to $1400{ }^{\circ} \mathrm{C}$ and oxygen partial pressures range of $10^{-2}$ atm to $10^{-6} \mathrm{~atm}$. It was found that the sulphide capacity increases with lime addition to a maximum $32 \mathrm{wt} \% \mathrm{CaO}$ and decreases with increasing $\mathrm{Al}_{2} \mathrm{O}_{3}, \mathrm{TiO}_{2}$ and $\mathrm{SiO}_{2}$ content in the fluxes saturated with lime.

An iron foil equilibrium technique was employed to obtain precise measurements of phosphorus distribution between carbon saturated iron and red mud based fluxes. The measurements indicate 
that the equilibrium phosphorus distribution ratio initially increases with rise in $\mathrm{FeO}$ or $\mathrm{CaO}$ concentration of the fluxes and then drops.

The melting behavior of the fluxes was also studied by visualizing the deformation of flux pellets as they were heated using a high temperature microscopy technique. Measurements of characteristic temperature for different fluxes indicated the melting property is a function of slag basicity. Therefore, optical basicity was used to establish a correlation between basicity of the red mud based fluxes and their melting properties. 


\section{Acknowledgements}

First, and most of all, I would like to thank my supervisor Professor Ravi Ravindran whose untiring support and seemingly unlimited belief in me made this research work possible.

I would also like to thank my co-supervisors Professors Alexander McLean and Mansoor Barati, for their excellent guidance, valuable discussion in analyzing the results and financial support during my graduate study.

I take this opportunity to thank Dr. Y. D. Yang for helping me to start the work and C-S analysis.

I am also grateful to Dr. H. Soda for valuable advice during this project.

I would like to extend my thanks to Mr. Alan Machin and Dr. Sophie Lun Sin for their kind help and support during this work.

I am indebted to George Kretschmann of Geology Dep. for XRD and Process Research ORTECH (PRO) for their assistance and support in XRF analyses.

I would like to offer my respects to my colleagues who supported me during the project in Nearnet-shape Processing of Materials (CNPM) group at Ryerson University and Sustainable Materials Processing Research (SMPR) group at the University of Toronto.

Lastly, I owe my deepest gratitude to my wife, son and daughter whose unhesitating support during my project enabled me to continue working with peace of mind.

Abdolkarim Danaei 


\section{Dedication}

To my wife, son and daughter 


\section{Table of Contents}

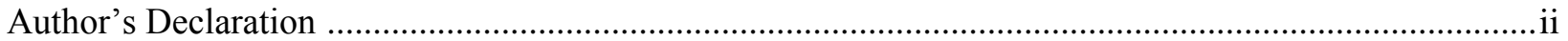

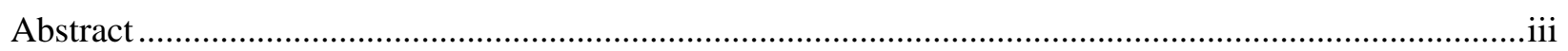

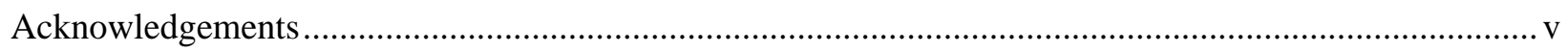

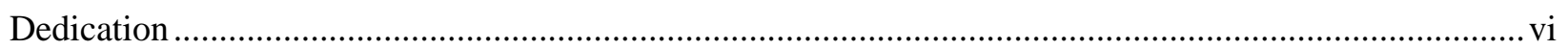

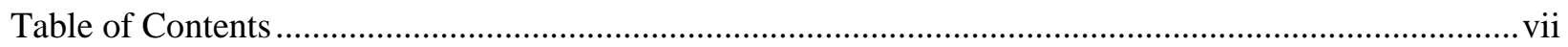

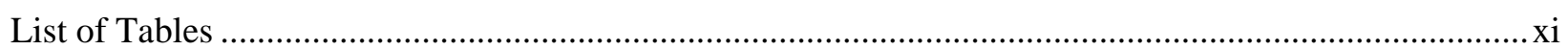

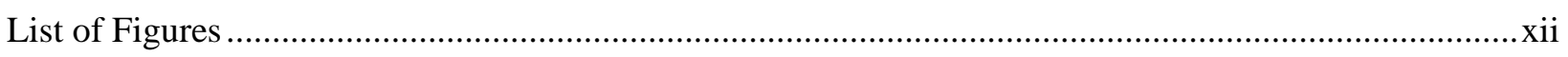

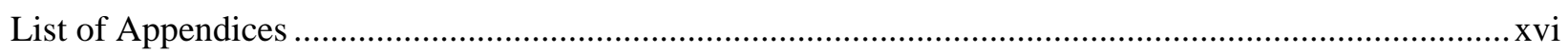

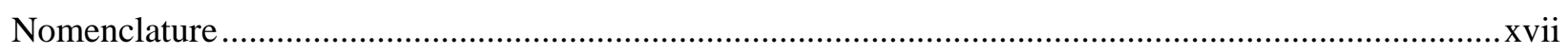

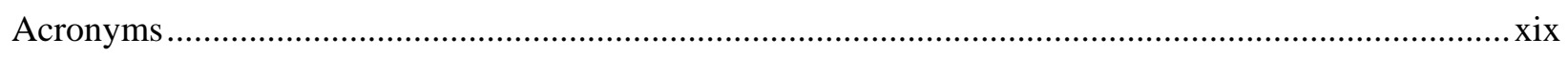

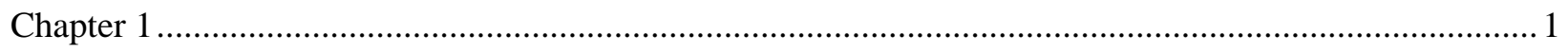

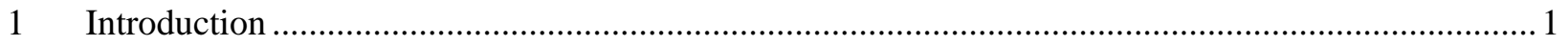

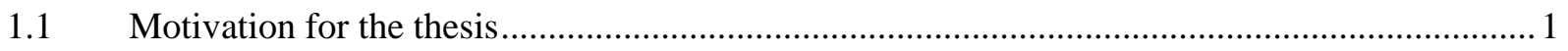

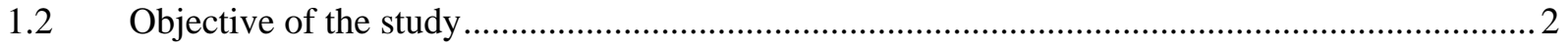

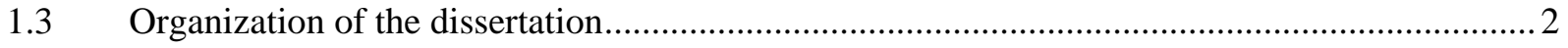

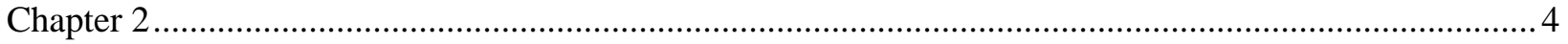

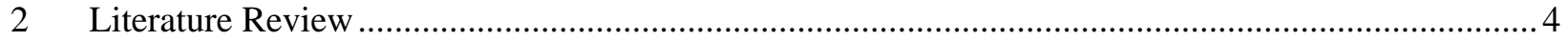

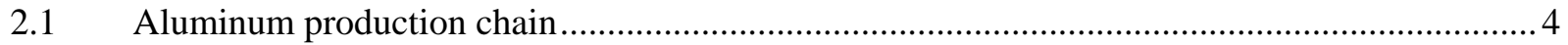

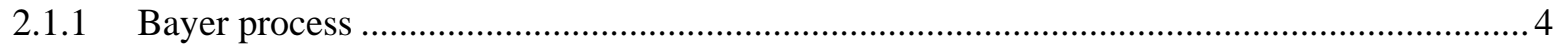

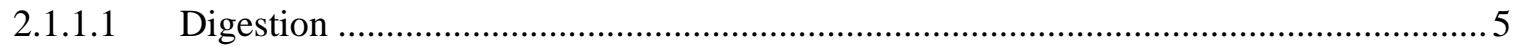

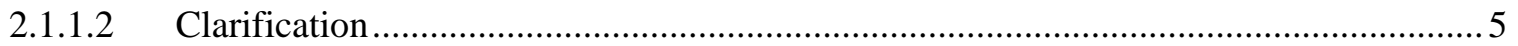

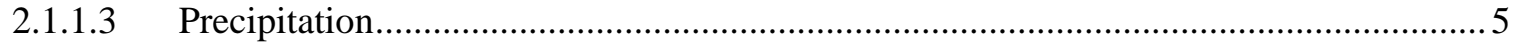

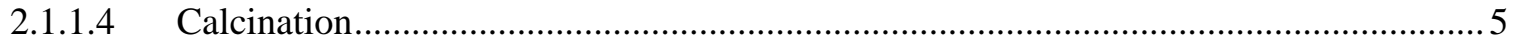

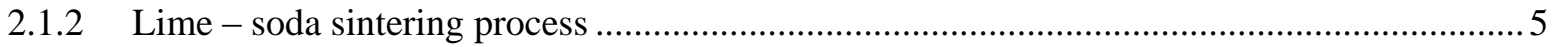

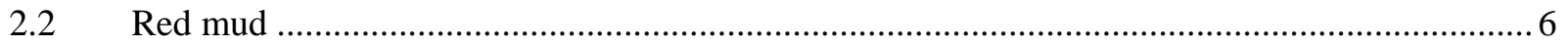

2.2.1 Chemical and mineralogical characteristics of red mud....................................................

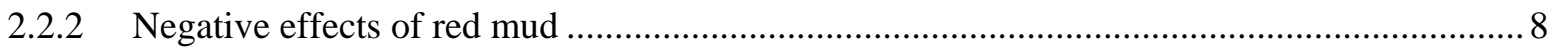

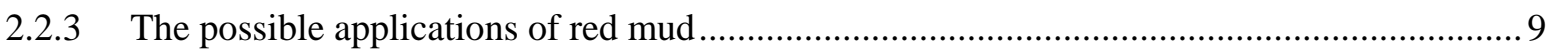

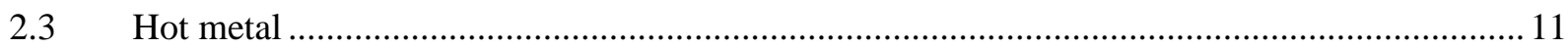

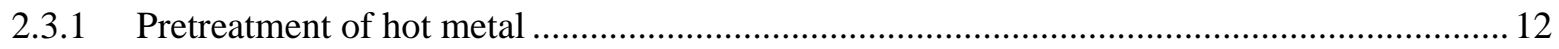

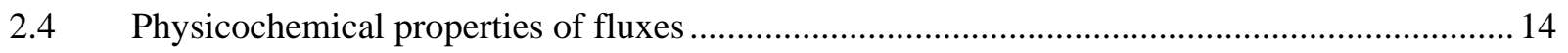

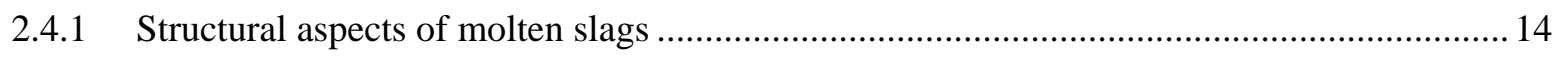

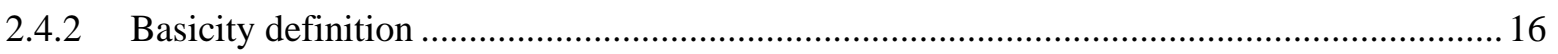




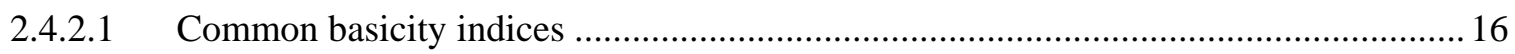

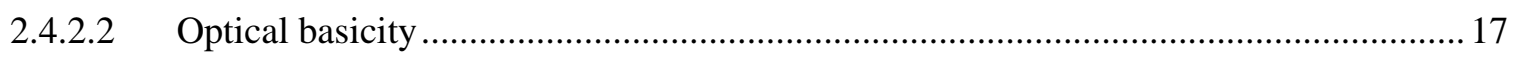

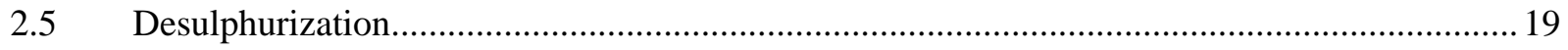

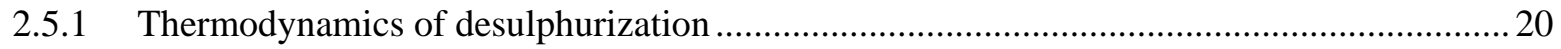

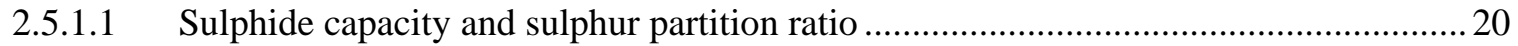

2.5.2 Composition and temperature dependence of sulphide capacity ........................................2 24

2.5.3 Relationship between optical basicity and sulphide capacity ............................................ 24

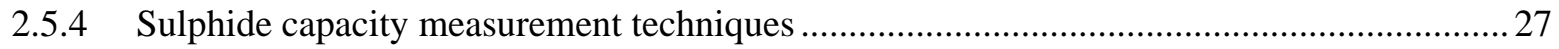

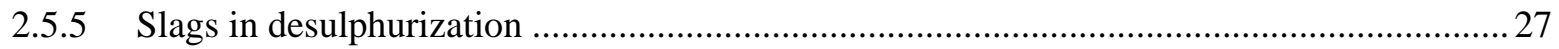

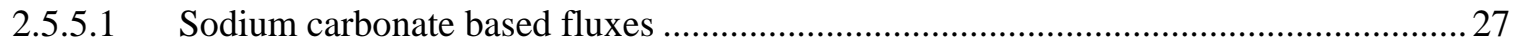

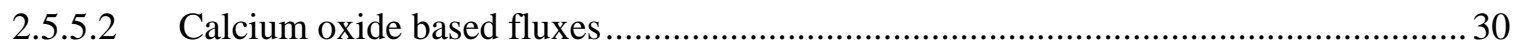

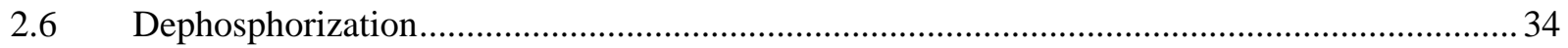

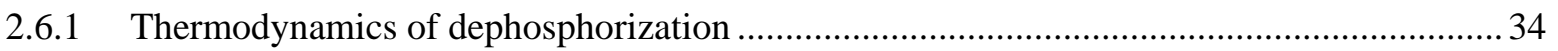

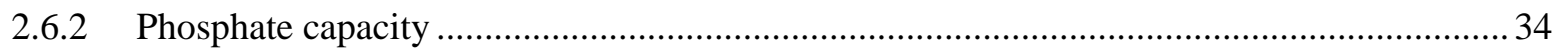

2.6.3 Relationship between phosphate capacity and optical basicity ......................................... 36

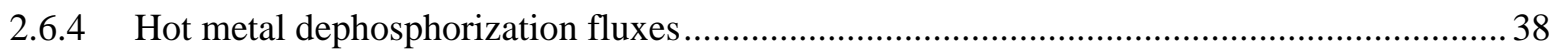

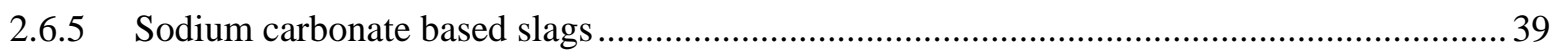

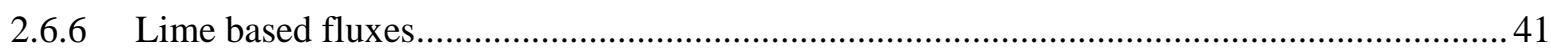

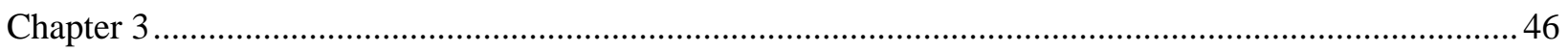

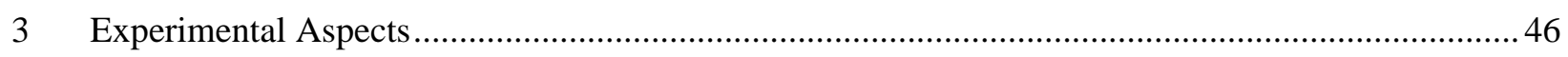

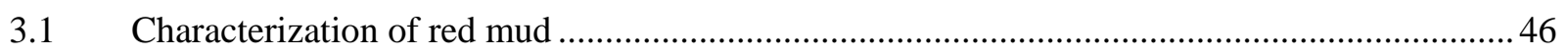

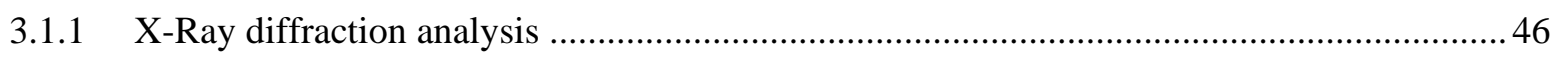

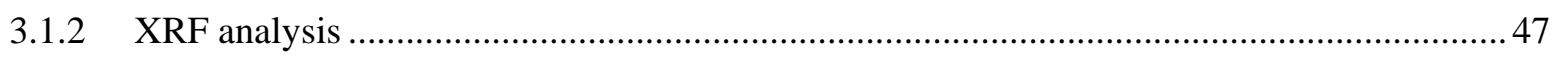

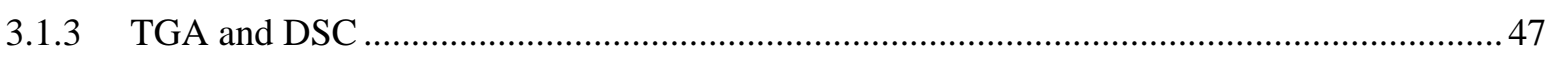

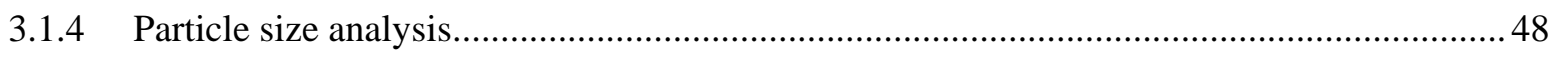

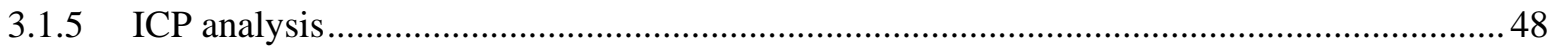

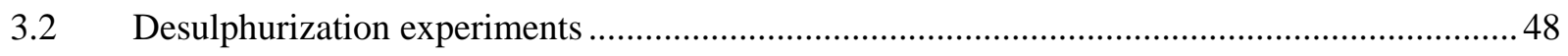

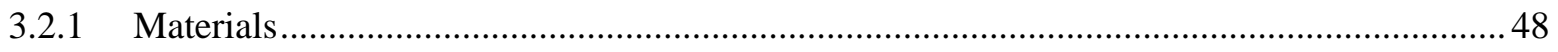

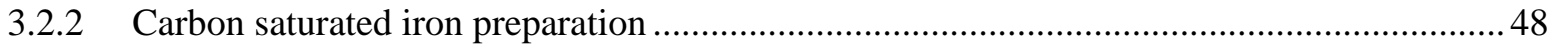

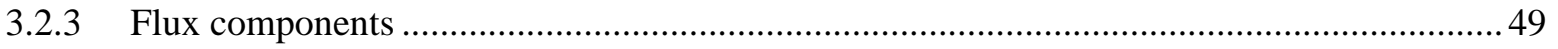

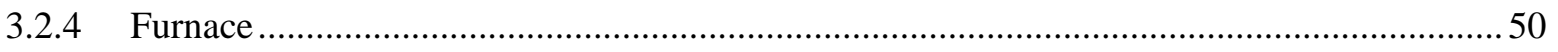

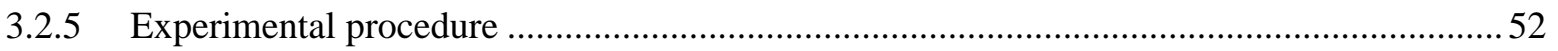

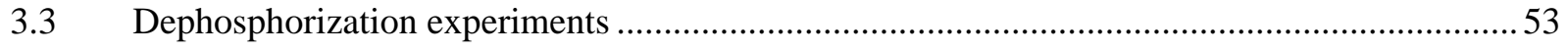

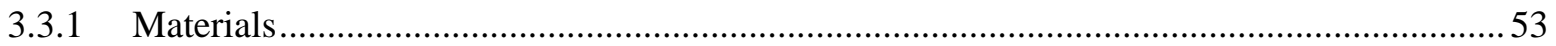




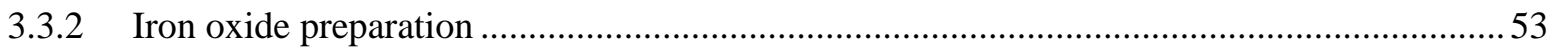

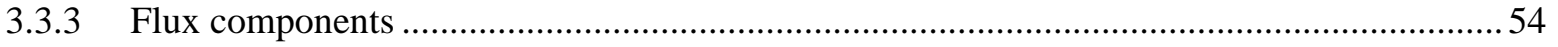

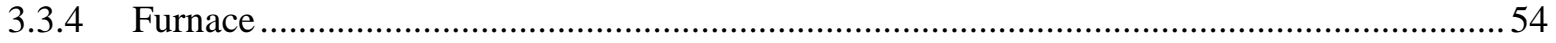

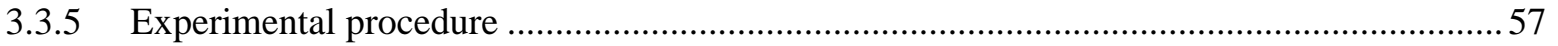

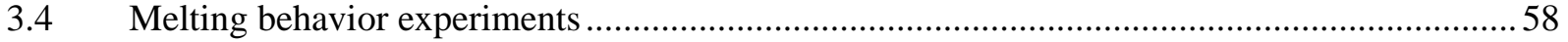

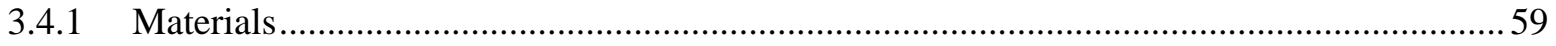

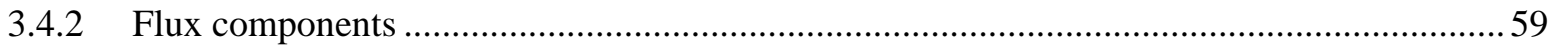

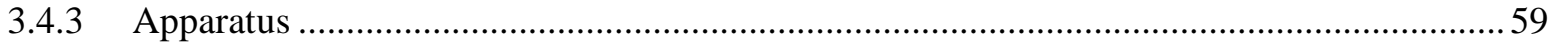

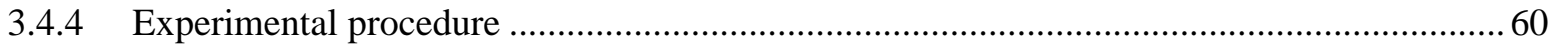

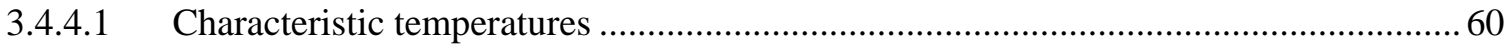

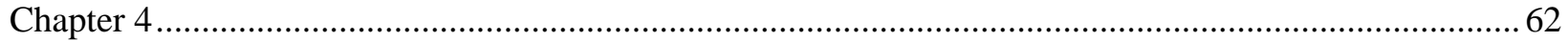

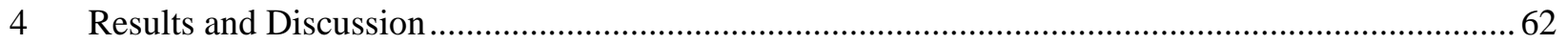

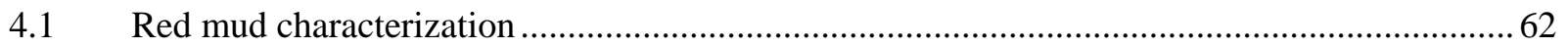

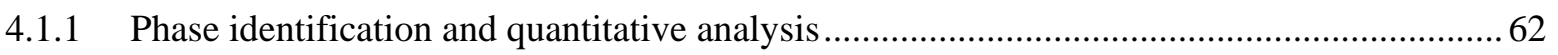

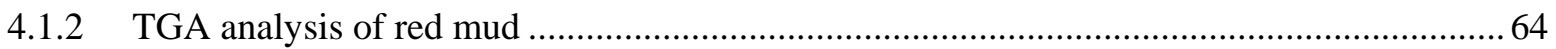

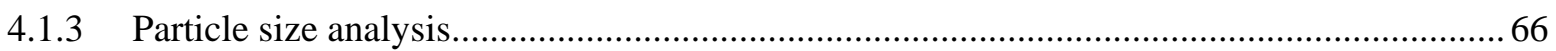

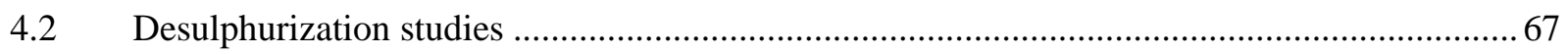

4.2.1 Sulphide capacity measurement between red mud based fluxes and hot metal ...................67

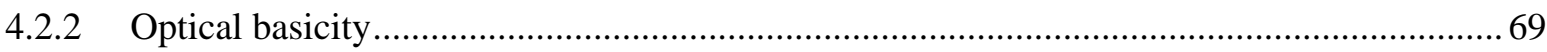

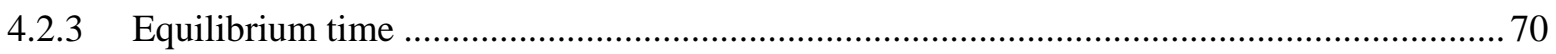

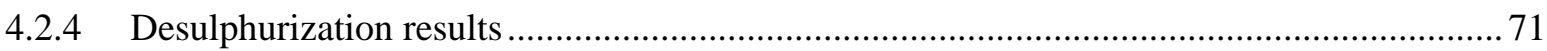

4.2.5 Effect of the basicity on the sulphide capacity of red mud based fluxes............................. 75

4.2.6 Effect of $\mathrm{CaO}$ on the optical basicity and the sulphide capacity of the red mud

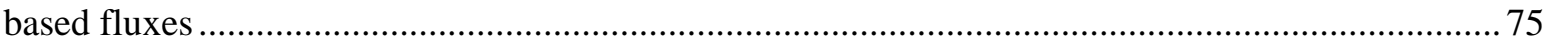

4.2.7 Effect of $\mathrm{Al}_{2} \mathrm{O}_{3}, \mathrm{TiO}_{2}$ and $\mathrm{SiO}_{2}$ on the optical basicity and sulphide capacity of

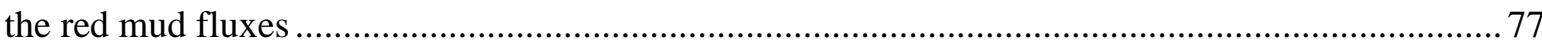

4.2.8 Effect of temperature on the sulphide capacity of red mud based fluxes .......................... 82

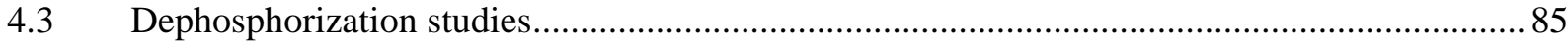

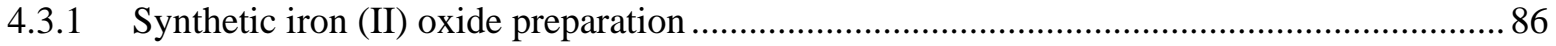

4.3.2 Phosphorus distribution ratio between red mud based fluxes and hot metal........................ 87

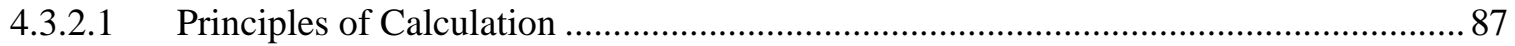

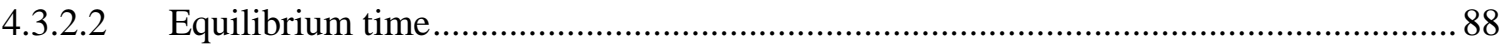

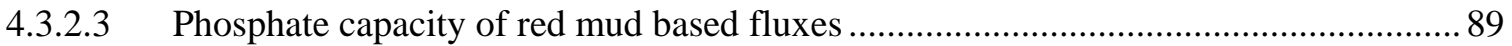

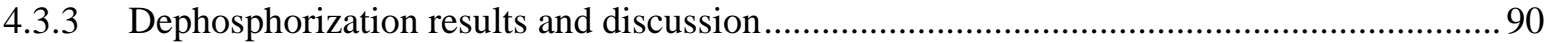


4.3.3.1 Effect of iron oxide on the phosphorus distribution ratio and phosphate capacity..... 94

4.3.3.2 Effect of $\mathrm{CaO}$ content on the phosphorus distribution ratio ....................................... 98

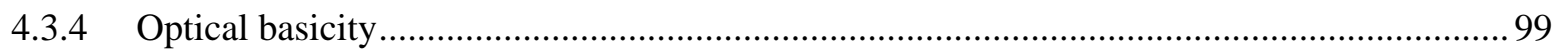

4.3.5 Effect of acidic oxides on the phosphorus distribution ratio and phosphate capacity

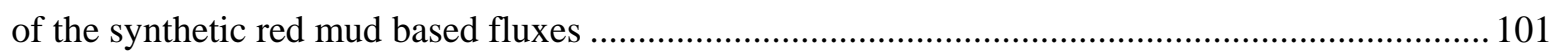

4.3.6 Effect of $\mathrm{SiO}_{2}$ on the phosphorus distribution ratio and phosphate capacity .................... 105

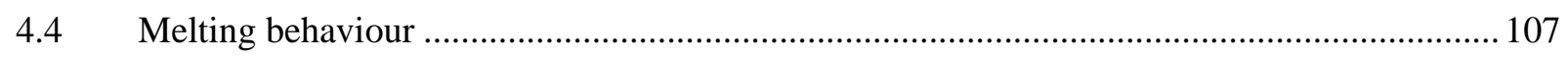

4.4.1 The relationship between flux components and melting behavior ..................................... 109

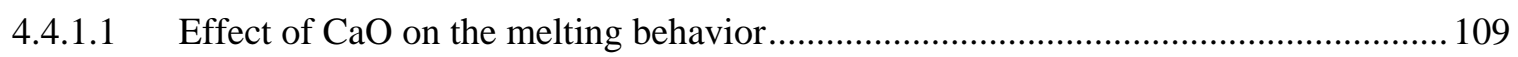

4.4.1.2 Effect of $\mathrm{Al}_{2} \mathrm{O}_{3}, \mathrm{TiO}_{2}$ and $\mathrm{SiO}_{2}$ on the melting behavior...................................... 110

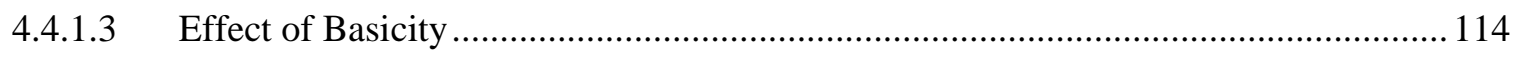

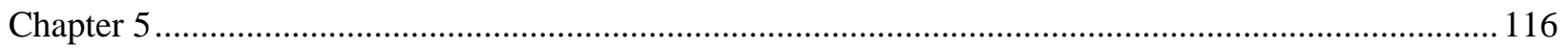

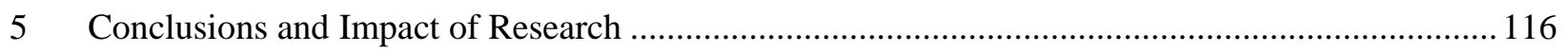

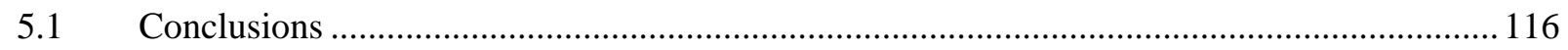

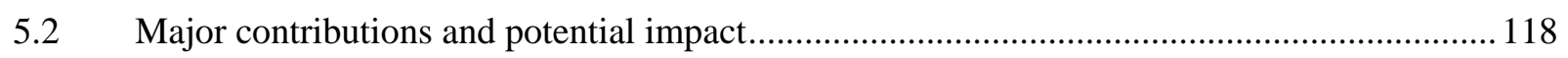

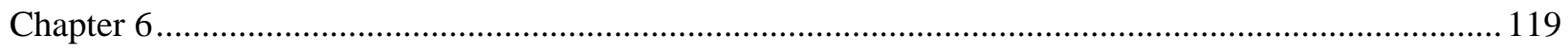

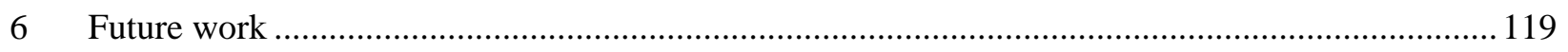

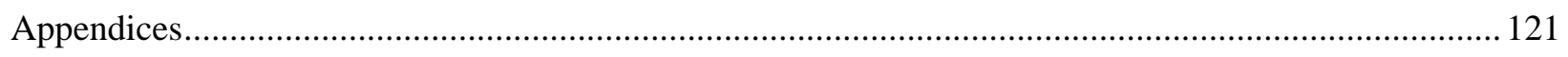

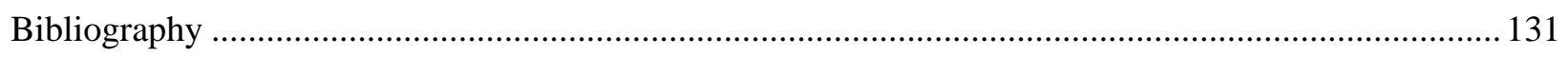




\section{List of Tables}

Table 2-1: Chemical composition of red muds from different operations $(\mathrm{wt} \%)$.................................. 8

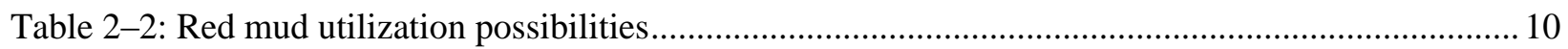

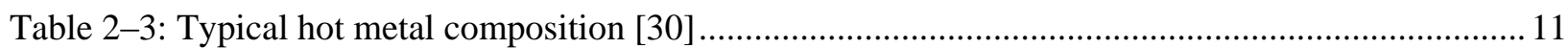

Table 2-4: Typical effects of phosphorus and sulphur in steel [32] ..................................................... 12

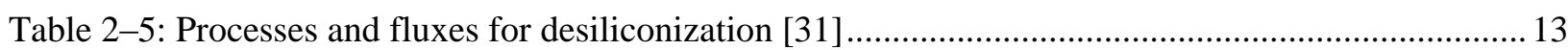

Table 2-6: Common processes and fluxes for dephosphorization and desulphurization [31].................. 13

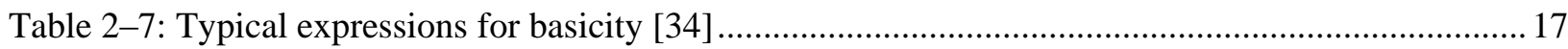

Table 2-8: Values of optical basicity of some oxides from different sources [44] .................................. 19

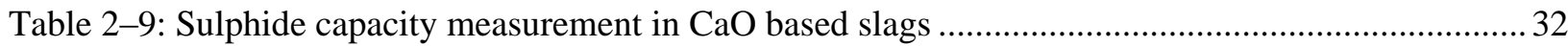

Table 3-1: Chemical composition of electrolytic iron and prepared carbon saturated iron (wt \%) ........... 49

Table 3-2: Flux compositions used in the desulphurization study ..........................................................50

Table 3-3: Flux compositions used in the dephosphorization study .....................................................55

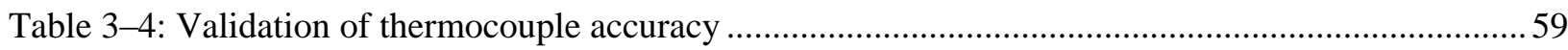

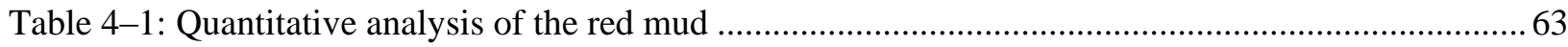

Table 4-2: Major chemical composition of red muds from different locations (wt\%) [98] .....................63

Table 4-3: Partial pressure of oxygen at different temperatures .............................................................6 68

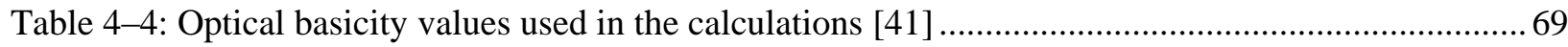

Table 4-5: Initial chemical compositions of red mud based fluxes used in the experiments .................... 70

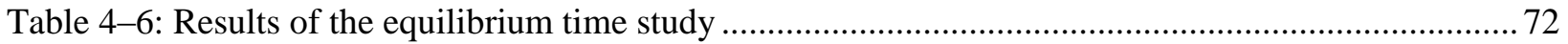

Table 4-7- Experimental results of sulphur equilibrium between flux and metal .................................. 73

Table 4-8: Initial chemical compositions of synthetic red mud based fluxes used in the experiments ...... 86

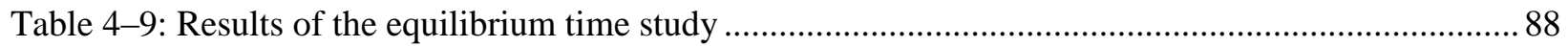

Table 4-10: Estimated energy of formation of $\mathrm{FeO}$ from FactSage ….................................................. 90

Table 4-11: Experimental results of phosphorus equilibrium between synthetic red mud flux

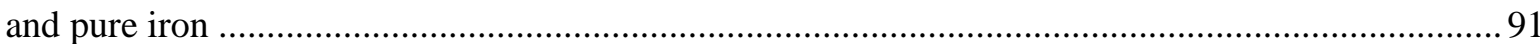

Table 4-12: The average characteristic temperatures, standard deviations and standard errors for red mud based fluxes.

\section{Appendix Tables}

Table A2- 1: Characteristics of the materials used for desulphurization experiments............................. 123

Table A2- 2: Characteristics of the materials used in dephosphorization experiments ........................... 124

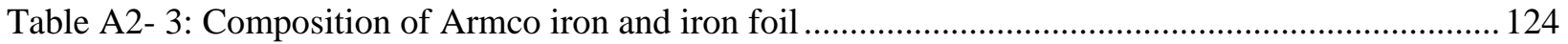

Table A2- 4: Characteristics of the materials used for the melting behavior experiments ...................... 125 


\section{List of Figures}

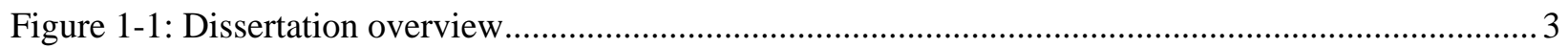

Figure 2-1: Alumina production flowcharts (a) Bayer process and (b) lime- soda sintering process........... 6

Figure 2-2: Accumulated bauxite residue (red mud) all over the world for 6 years [3] ............................ 7

Figure 2-3: The red mud catastrophe in Hungary, October 2010 (Air photo by Digital Globe) ................. 9

Figure 2-4: Two dimensional schematic representation of (a) crystalline and (b) molten silica [31].

Figure 2-5: Schematic structural of depolymerization of silicate network with the addition of a

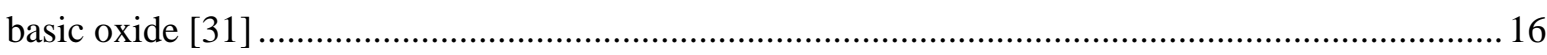

Figure 2-6: Relationship between sulphide capacity and optical basicity of slags at $1500{ }^{\circ} \mathrm{C}[41] \ldots \ldots \ldots . .25$

Figure 2-7: Plot of the logarithm of the sulphide capacity vs. 1/T for various iso-optical basicities [41] .25

Figure 2-8: Relationship between $\log \mathrm{C}_{\mathrm{S}}$ and temperature in $\mathrm{CaO}-\mathrm{Al}_{2} \mathrm{O}_{3}-\mathrm{SiO}_{2}-\mathrm{MgO}$ slags, numerical

values show optical basicity [52]

Figure 2-9: Correlation between $\mathrm{Na}_{2} \mathrm{O}$ mole fraction and sulphide capacities at $1200{ }^{\circ} \mathrm{C}$ as measured by the gas-slag method and partition ratio data from slag-metal converted to sulphide capacity via the

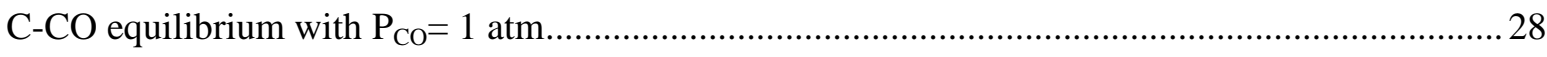

Figure 2-10: Measured sulphur partition ratio data from Chan and Fruehan [56] and Inoue and Suito [54]

Figure 2-11: Effect of $\mathrm{CaO}, \mathrm{MnO}, \mathrm{MgO}$ and $\mathrm{Al}_{2} \mathrm{O}_{3}$ on the sulphide capacity of $\mathrm{Na}_{2} \mathrm{O}-\mathrm{SiO}_{2}$ slags [57]. 30

Figure 2-12: Sulphide capacity of $\mathrm{CaO}$ based slags [59] 31

Figure 2-13: Relationship between sulphide capacity and optical basicity of $\mathrm{CaO}-\mathrm{CaCl}_{2}$ slags [64]. .33

Figure 2-14: Sulphur partition ratio of $\mathrm{CaO}-\mathrm{Na}_{2} \mathrm{O}-\mathrm{SiO}_{2}$ slags at $1400{ }^{\circ} \mathrm{C}$ plotted at different $\mathrm{Na}_{2} \mathrm{O}$ levels [59] . .33

Figure 2-15: Relationship between $\log \mathrm{C}_{\mathrm{PO} 4}{ }^{3-}$ and optical basicity [71] ............................................... 37

Figure 2-16: Comparison of the phosphate capacity of slags from different studies [44] ........................ 38

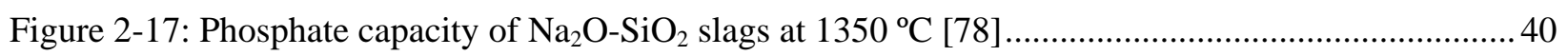

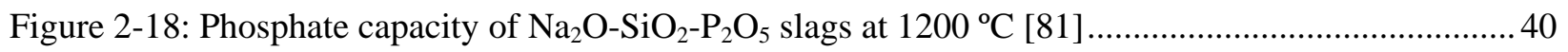

Figure 2-19: Relationship between phosphate capacity and optical basicity at $1400{ }^{\circ} \mathrm{C}$ [82] .................. 41

Figure 2-20: Relationship between the phosphate capacity and $\mathrm{FeO}(\mathrm{wt} \%)$ for the $\mathrm{CaO}-\mathrm{SiO}_{2}-\mathrm{FeO}$

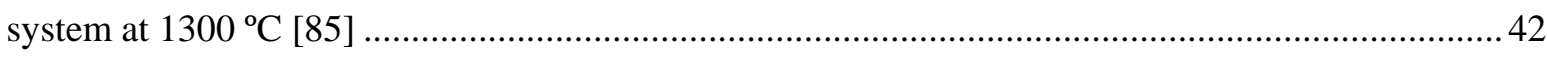

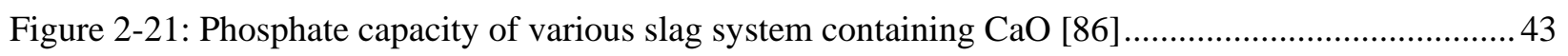


Figure 2-22: Variation in phosphorus distribution with $\mathrm{FeO}$ content at different basicities [87]

Figure 2-23: Equilibrium phosphorus distribution between $\left(\mathrm{C}_{2} \mathrm{~S}-\mathrm{C}_{3} \mathrm{P}\right)_{\mathrm{SS}}$ saturated slags and carbon

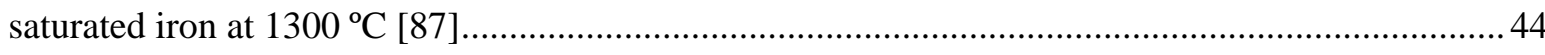

Figure 2-24: Effect of temperature on phosphate capacity of $\mathrm{CaO}-\mathrm{CaCl}_{2}$ slags [64] ............................. 45

Figure 3-1: Red mud from Bayer process; (a) Fresh red mud; (b) Dried red mud ................................... 47

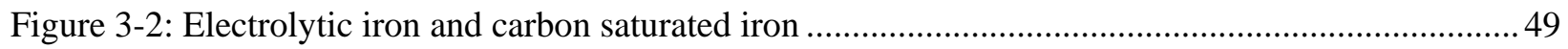

Figure 3-3: Schematic diagram of the experimental set up for the vertical furnace ................................51

Figure 3-4: Temperature profile in the vertical tube furnace ................................................................52

Figure 3-5: Schematic diagram of the experimental set up for the horizontal furnace .............................56

Figure 3-6: Temperature profile and hot zone of the horizontal tube furnace .......................................57

Figure 3-7: (a) ARMCO iron crucible; (b) Pure iron foil before experiment; (c) Iron foil

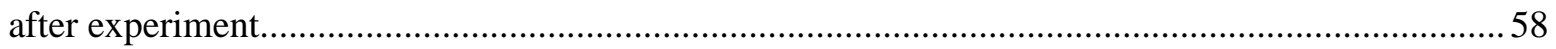

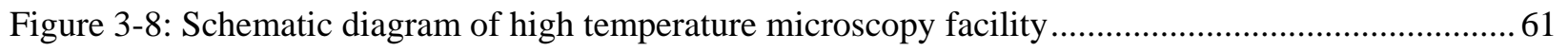

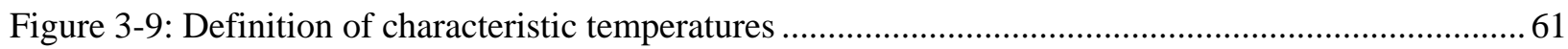

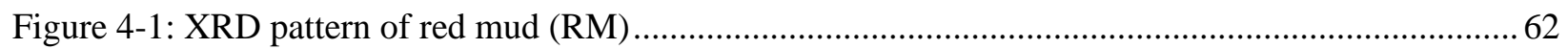

Figure 4-2: TGA, DSC and DTG curves obtained from thermal analysis of red mud ............................. 65

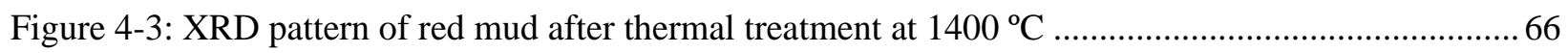

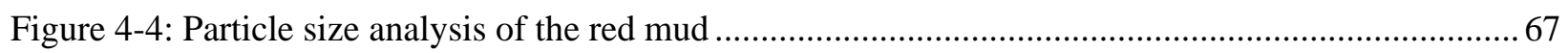

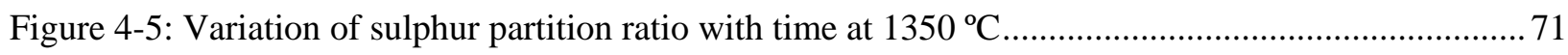

Figure 4-6: Relationship between sulphide capacity and optical basicity .............................................. 75

Figure 4-7: Relationship between optical basicity and mole fraction of lime in the red mud

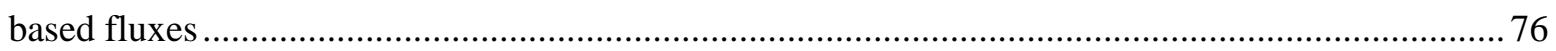

Figure 4-8: Effect of $\mathrm{CaO}$ on the sulphide capacity at different temperatures ....................................... 77

Figure 4-9: Effect of $\mathrm{Al}_{2} \mathrm{O}_{3}$ on the sulphide capacity at different temperatures .................................... 78

Figure 4-10: Effect of $\mathrm{TiO}_{2}$ on the sulphide capacity at different temperatures ....................................... 79

Figure 4-11: Effect of $\mathrm{Al}_{2} \mathrm{O}_{3}$ on the optical basicity at different temperatures ....................................... 79

Figure 4-12: Effect of $\mathrm{TiO}_{2}$ on the optical basicity at different temperatures ........................................ 80

Figure 4-13: Effect of $\mathrm{SiO}_{2}$ on the sulphide capacity at different temperatures .................................... 81

Figure 4-14: Effect of $\mathrm{SiO}_{2}$ on the different oxygen bondings [105] ................................................... 81

Figure 4-15- Effect of $\mathrm{SiO}_{2}$ on optical basicity at different temperatures................................................ 82

Figure 4-16: Relationship between sulphide capacity and temperature ................................................. 84

Figure 4-17- Relationship between the enthalpy of sulphur transfer to flux and optical basicity .............. 84

Figure 4-18: Relationship between $\log \mathrm{C}_{\mathrm{s}}$ and temperature (data from this study and literature) .............. 85

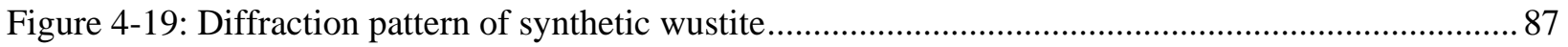




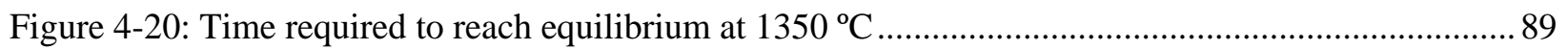

Figure 4-21: Effect of iron oxide content on the phosphorus distribution ratio $\left(\mathrm{L}_{\mathrm{P}}^{\mathrm{Fe}-\mathrm{C}}\right)$........................ 94

Figure 4-22: Effect of $\mathrm{FeO}$ content on $\mathrm{L}_{\mathrm{P}}$ at different basicity [108].................................................. 95

Figure 4-23: Effect of iron oxide content on the phosphate capacity .................................................... 95

Figure 4-24: Equilibrium phosphorus distribution between various fluxes and carbon-saturated

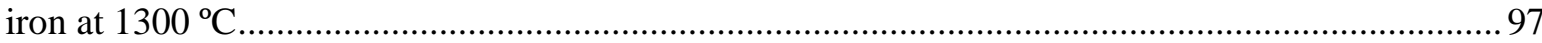

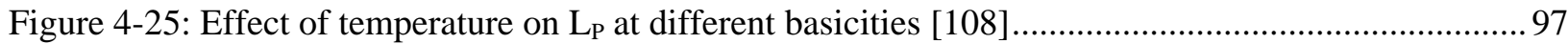

Figure 4-26: Relationship between the phosphorus distribution ratio $\left(\mathrm{L}_{\mathrm{P}}^{\mathrm{Fe}-\mathrm{C}}\right)$ and lime content .............. 98

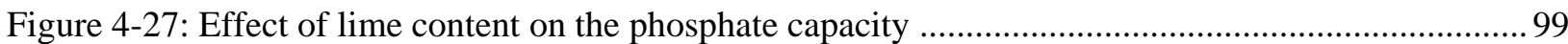

Figure 4-28: Correlation between the phosphorus distribution ratio $\left(\mathrm{L}_{\mathrm{P}}{ }^{\mathrm{Fe}-\mathrm{C}}\right)$ and optical basicity ............ 100

Figure 4-29: Correlation between phosphate capacity and optical basicity ........................................... 100

Figure 4-30: Comparison of the phosphate capacities of different slags and present study .................... 101

Figure 4-31: Relationship between the phosphorus distribution ratio $\left(\mathrm{L}_{\mathrm{P}}{ }^{\mathrm{Fe}-\mathrm{C}}\right.$ ) and $\mathrm{wt} \% \mathrm{Al}_{2} \mathrm{O}_{3} \ldots \ldots \ldots \ldots . . . . .102$

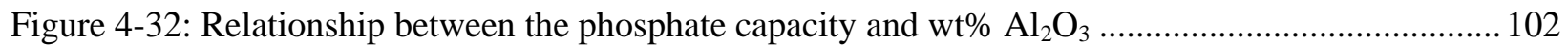

Figure 4-33: Relationship between the phosphorus distribution ratio $\left(\mathrm{L}_{\mathrm{P}}^{\mathrm{Fe}-\mathrm{C}}\right)$ and $\mathrm{wt} \% \mathrm{TiO}_{2} \ldots \ldots \ldots \ldots \ldots . . . . . .103$

Figure 4-34: Relationship between the phosphate capacity and $\mathrm{wt}^{2} \mathrm{\textrm {TiO } _ { 2 }}$........................................ 103

Figure 4-35: Effect of $\mathrm{Al}_{2} \mathrm{O}_{3}$ on the phosphorus distribution ratio at $1350{ }^{\circ} \mathrm{C}$ [110] ............................. 104

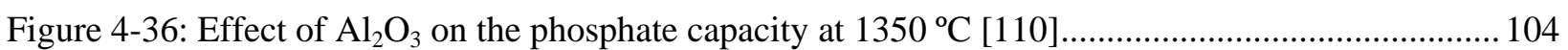

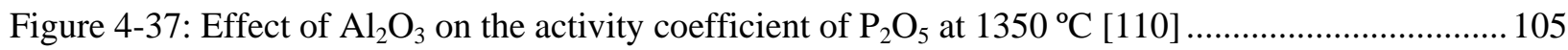

Figure 4-38: Relationship between the Phosphorus distribution ratio $\left(\mathrm{L}_{\mathrm{P}}^{\mathrm{Fe}-\mathrm{C}}\right)$ and wt\% $\mathrm{SiO}_{2} \ldots \ldots \ldots \ldots \ldots . . . . . . .106$

Figure 4-39: Relationship between the Phosphate capacity and $\mathrm{wt} \% \mathrm{SiO}_{2}$........................................... 106

Figure 4-40: Typical captured image of characteristic temperatures belong to sample RMF4 ............... 107

Figure 4-41: Effect of lime on characteristic temperatures of fluxes RMF1 through RMF6 .................. 109

Figure 4-42: Phase diagram of $\mathrm{CaO}-\mathrm{SiO}_{2}$ system [113] ............................................................... 110

Figure 4-43: Effect of alumina on characteristic temperatures of fluxes RMF7 through RMF10........... 111

Figure 4-44: Effect of titanium oxide on characteristic temperatures of fluxes RMF11 through RMF14

Figure 4-45: Effect of silica on characteristic temperatures of fluxes RMF15 through RMF18 ............. 112

Figure 4-46: Mass percentage of liquid phase in slag vs. alumina content at different temperatures....... 113

Figure 4-47: Mass percentage of liquid phase in slag vs. titania content at different temperatures ......... 113

Figure 4-48: Mass percentage of liquid phase in slag vs. silica content at different temperatures ........... 114

Figure 4-49: Characteristic temperatures of mold fluxes as a function of the $\mathrm{CaO} / \mathrm{SiO}_{2}$ ratio[114] ........ 115

Figure 4-50: Characteristic temperatures as a function of the optical basicity for RMF1 through RMF6 fluxes 


\section{Appendix Figures}

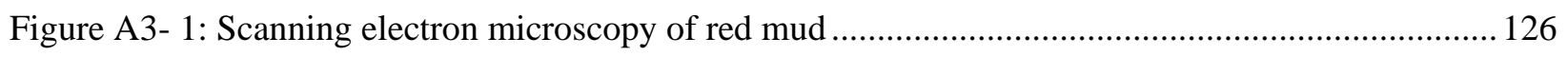

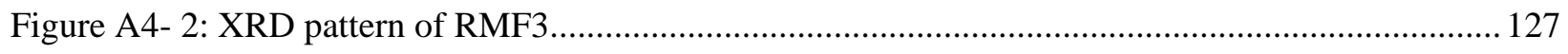

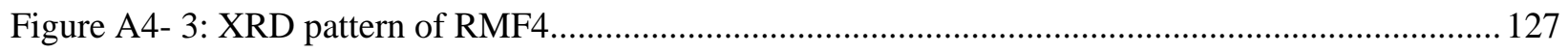

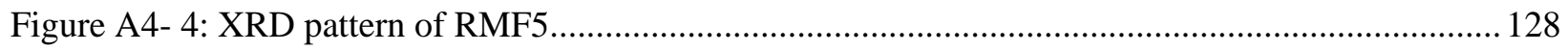

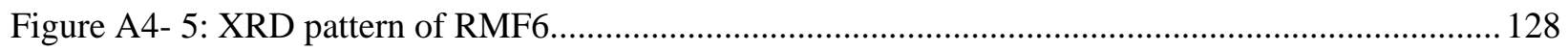




\section{List of Appendices}

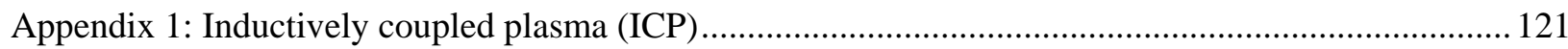

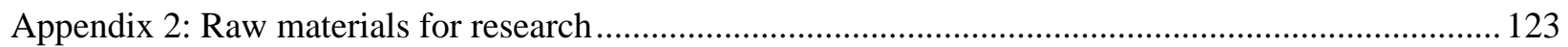

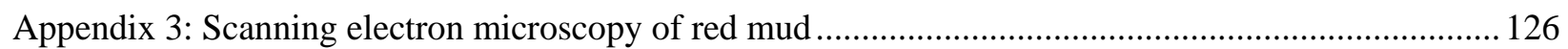

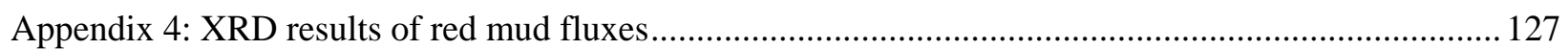

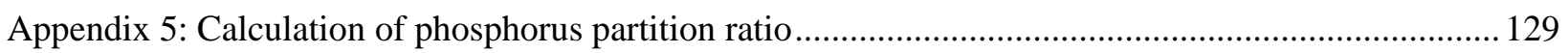




\section{Nomenclature}

\begin{tabular}{|c|l|c|}
\hline Symbol & \multicolumn{1}{|c|}{ Definition } & Units \\
\hline $\mathrm{a}_{\mathrm{i}}$ & The activity of component $\mathrm{i}$ & - \\
\hline $\mathrm{a}_{\mathrm{O}}$ & Activity of oxygen & \\
\hline $\mathrm{C}_{\mathrm{s}}$ & Sulphide capacity of slag & - \\
\hline $\mathrm{C}_{\mathrm{PO}_{4}^{-3}}$ & Phosphate capacity of slag & $\mathrm{J} / \mathrm{mol}$ \\
\hline$\Delta \mathrm{G}$ & Gibbs free energy & $\mathrm{J} / \mathrm{mol}$ \\
\hline $\mathrm{G}_{\mathrm{i}}^{\circ}$ & Gibbs free energy of component $\mathrm{i}$ in standard state & \\
\hline$e_{i}^{j}$ & Interaction coefficient of $i$ as affected by alloying element $j$ & $\mathrm{~g} / \mathrm{mol}$ \\
\hline$f$ & Henrian activity coefficient, $1 \mathrm{wt} \%$ & $\mathrm{~mol}$ \\
\hline$K_{\mathrm{c}}$ & Equilibrium constant & - \\
\hline $\mathrm{L}_{\mathrm{P}}$ & Phosphorus distribution ratio $(\mathrm{wt} \% \mathrm{P}) /[\mathrm{wt} \% \mathrm{P}]$ & - \\
\hline $\mathrm{N}_{\mathrm{i}}$ & Molecular weight & - \\
\hline $\mathrm{n}_{\mathrm{O}_{\mathrm{i}}}$ & Number of oxygen atoms in component, $\mathrm{i}$, & - \\
\hline
\end{tabular}




\begin{tabular}{|c|l|c|}
\hline 0 & Number of oxygen atom in molecule & atm \\
\hline$P_{\text {gas }}$ & Partial pressure of gas & 8.314 J/mol $\cdot \mathrm{K}$ \\
\hline $\mathrm{R}$ & Gas constant & Kelvin $(\mathrm{K})$ \\
\hline $\mathrm{T}$ & Temperature & - \\
\hline$x$ & Pauling's electronegativity & wt $\%$ \\
\hline $\mathrm{X}$ & Equivalent fraction of oxide & wt $\%$ \\
\hline$v$ & Frequency of light wave & - \\
\hline$[\mathrm{P}],[\mathrm{S}]$ & Weight percent of sulphur or phosphorus in metal phase & - \\
\hline$(\mathrm{P}),(\mathrm{S})$ & Weight percent of sulphur or phosphorus in slag phase & \\
\hline$\Lambda$ & Optical basicity of a multicomponent slag & \\
\hline$\Lambda_{\mathrm{i}}$ & Optical basicity of an oxide component & \\
\hline
\end{tabular}




\section{Acronyms}

\begin{tabular}{|c|l|}
\hline AES & Atomic Emission Spectroscopy \\
\hline BOF & Basic Oxygen Furnace \\
\hline DSC & Differential Scanning Calorimetry \\
\hline DTG & Derivative Thermogravimetric Analysis \\
\hline IAI & International Aluminum Institute \\
\hline ICDD & International Centre for Diffraction Data \\
\hline ICP & Inductively Coupled Plasma \\
\hline OB & Optical Basicity \\
\hline RIR & Reference Intensity Ratio \\
\hline RM & Red Mud (Bauxite residue) \\
\hline RMF & Red Mud Flux \\
\hline SD & Standard Deviation \\
\hline SE & Standard Error \\
\hline SEM & Scanning Electron Microscope \\
\hline SRM & Synthetic Red Mud flux \\
\hline STA & Simultaneous Thermal Analysis \\
\hline TGA & Thermal Gravimetric Analysis \\
\hline UV & Ultraviolet (UV) light \\
\hline XRD & X-Ray Diffraction \\
\hline XRF & X-Ray Fluorescence Spectroscopy \\
\hline
\end{tabular}




\section{Chapter 1}

\section{Introduction}

\subsection{Motivation for the thesis}

Aluminum is an abundant element and critical to the daily lives of human beings. However, it can take a long and costly procedure to be extracted from the earth's crust. Aluminum exists primarily as alumina (aluminum oxide), which is extracted from bauxite ore, although other types of ore may also be used as the source of alumina. The Bayer process is the dominant route to extract alumina from Bauxite ore. During the process, a residue amounting to about 120 million tonnes per year is generated. The residue is known as "red mud" - so-called because of its red color resulting from a substantial amount of iron oxide content. It is also quite alkaline and thus harmful to many forms of life. Direct disposal of the material is therefore not possible and it is stored in large pools within the plant's vicinity. Development of solutions for safe disposal or possible development of ways of using this residue for other industrial processes could help to restore polluted locations and eliminate negative impacts on the environment.

Within steelmaking operations, approximately $200 \mathrm{~kg}$ (electric furnace route) to $400 \mathrm{~kg}$ (blast furnace/ converter route) of slag are produced for making one tonne of liquid steel, resulting in generation of more than 400 million tonnes of iron and steel slag each year. Steelmaking slags are a mixture of silica, calcium oxide, magnesium oxide, aluminum oxide and iron oxides. The amount of discarded slag can be significantly reduced when the steelmaking converter is charged with blast furnace hot metal (also known as pig iron) which has been treated to partially remove phosphorus and sulphur impurities. The focus of the present research is to examine the feasibility of using red mud based fluxes for the refining of blast furnace hot metal. The advantage of this approach is to use the waste material from the aluminum industry to reduce the waste slag produced by the steel industry. Reuse of the red mud prevents landfill waste, helps preserve

natural resources and supports the sustainability of the aluminum industry. In addition, it should also generate additional revenues for the aluminum and steelmaking industries. The main thrust of this study is the development of a potential application for red mud - a fluxing agent with high refining capacity - to absorb harmful impurities such as phosphorus and sulphur from hot metal. 


\subsection{Objective of the study}

The specific objectives of the research can be defined as follows.

1. Physical and chemical characterization of the red mud.

2. Design and thermo-chemical evaluation of synthetic fluxes for dephosphorization and desulphurization of hot metal.

3. Determination of the melting properties of red mud based fluxes containing additives such as $\mathrm{CaO}, \mathrm{Al}_{2} \mathrm{O}_{3}, \mathrm{Na}_{2} \mathrm{O}$ and $\mathrm{SiO}_{2}$.

4. Examination of the effect of the above additives on the phosphate and sulphide capacities of molten slag.

5. Measurement of the phosphorus and sulphur distribution between carbon saturated iron and red mud based slags.

\subsection{Organization of the dissertation}

This dissertation has been structured in five chapters as follow. Chapter 2 presents a review of literature pertaining to the present study including a general review of red mud, hot metal treatment, desulphurization and dephosphorization. This chapter also presents the fundamental aspects of desulphurization and dephosphorization. The experimental design is explained in Chapter 3 along with the experimental conditions and measurement techniques. The experimental results are provided and discussed in Chapter 4. Chapter 5 presents the conclusions arising from this research. Chapter $\mathbf{6}$ lists a series of recommendation for future work. An overview of the research is shown schematically in Figure 1-1. 

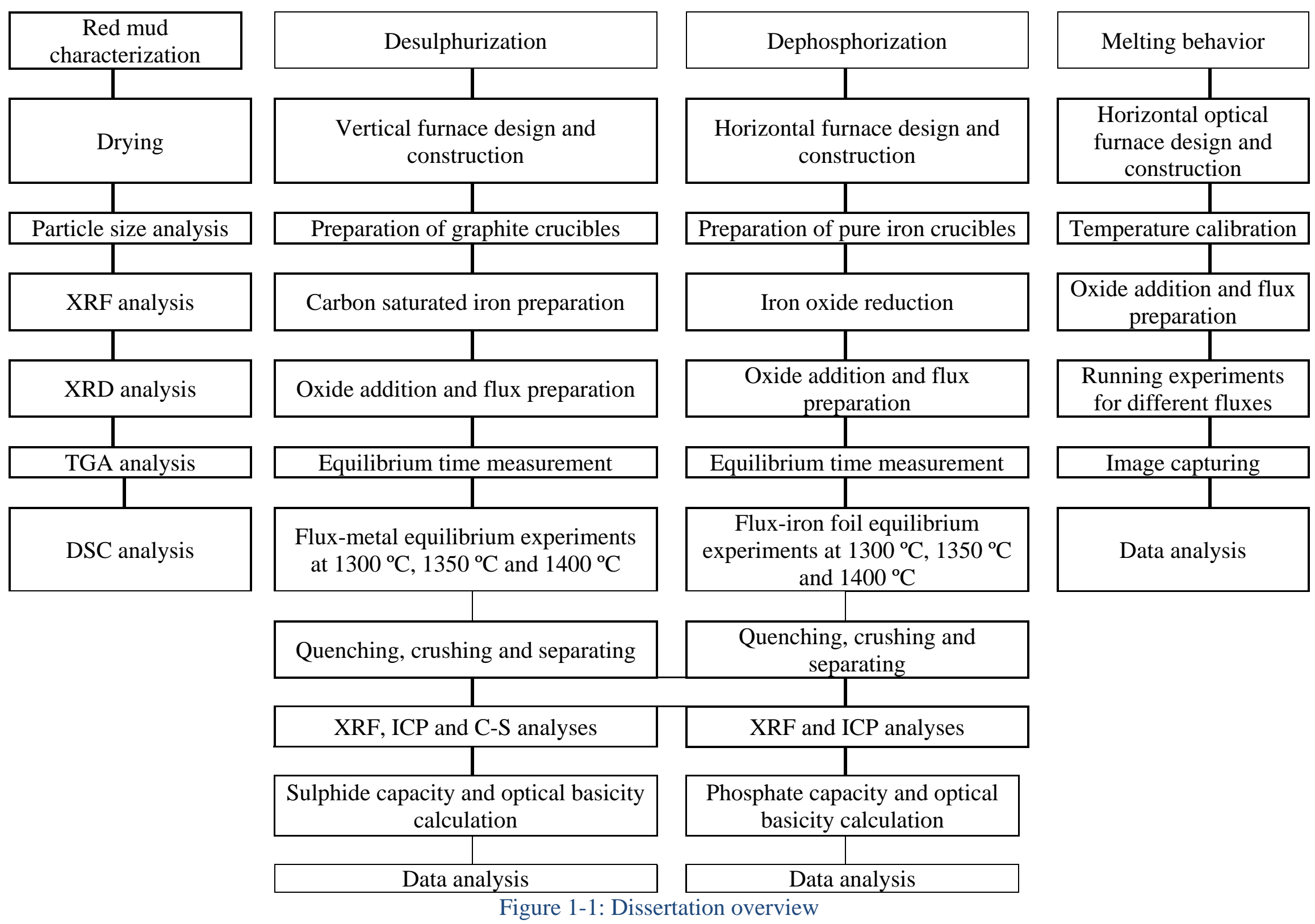

Equilibrium time measurement

Flux-iron foil equilibrium experiments at $1300^{\circ} \mathrm{C}, 1350{ }^{\circ} \mathrm{C}$ and $1400^{\circ} \mathrm{C}$
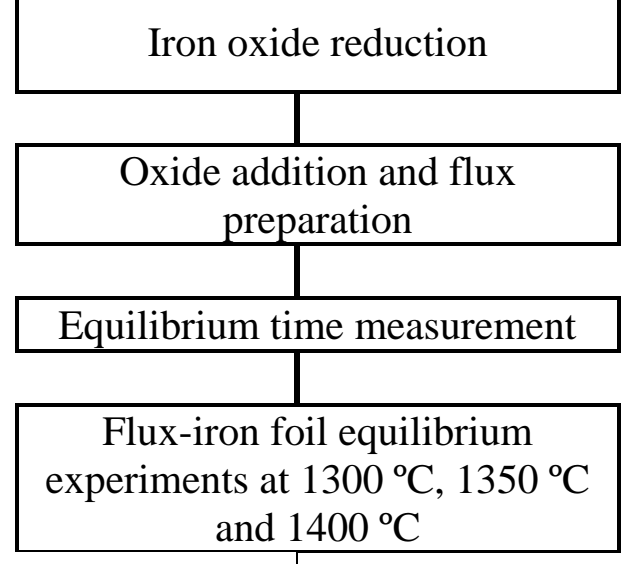

Eissertation overview 


\section{Chapter 2}

\section{Literature Review}

In this chapter, a literature review is presented to explain the source of red mud and its possible applications (Sections 2.1 and 2.2). Hot metal and refining flux properties are discussed in Sections 2.3 and 2.4 respectively. Theoretical consideration of desulphurization and dephosphorization of hot metal and published results are described in Sections 2.5 and 2.6 respectively.

\subsection{Aluminum production chain}

Alumina (aluminum oxide, $\mathrm{Al}_{2} \mathrm{O}_{3}$ ) is an essential raw material for aluminum industries. The most significant aluminum ore is bauxite. Bauxite consists mostly of the minerals gibbsite $\left(\mathrm{Al}(\mathrm{OH})_{3}\right)$, boehmite $(\gamma-\mathrm{AlO}(\mathrm{OH}))$, and diaspore $(\alpha-\mathrm{AlO}(\mathrm{OH}))$ in a mixture with the two iron oxides goethite $(\mathrm{FeO}(\mathrm{OH}))$ and hematite $\left(\mathrm{Fe}_{2} \mathrm{O}_{3}\right)$, and small amounts of anatase $\left(\mathrm{TiO}_{2}\right)[1]$.

Extracting aluminum from bauxite involves two processes. First, the ore can be refined by the Bayer process, the lime - soda sintering process, or a combined process to eliminate impurities such as iron oxide, silica and titanium oxide. When the ratio of alumina to silicon oxide in bauxite is higher than 7:10, the Bayer process is used to extract alumina from the bauxite, Figure 2-1a. On the other hand, the lime- soda sintering process is employed for the treatment of low quality bauxite ores, as illustrated in Figure 2-1b. Then, the final product (i.e., high-grade metallurgical alumina $\left[\mathrm{Al}_{2} \mathrm{O}_{3}\right]$ ), is electrolyzed using the Hall-Heroult process to produce primary aluminum $[1,2]$.

\subsubsection{Bayer process}

The Bayer process is the main route for alumina production. This process was patented by Bayer in 1892. The process involves four steps: digestion, clarification, precipitation, and calcination as depicted in Figure 2-1a. 


\subsubsection{Digestion}

In this step, ground bauxite is mixed with a hot solution of sodium hydroxide at $106^{\circ} \mathrm{C}-240^{\circ} \mathrm{C}$, and pumped into large pressure tanks called digesters. The sodium aluminate is formed by the reaction of sodium hydroxide with the aluminous minerals of bauxite. Insoluble impurities remain in suspension and are separated in the clarification step and called bauxite residue. Lime $(\mathrm{CaO})$ is also introduced in the Bayer process to enhance the extraction of alumina[1].

$$
\begin{gathered}
\mathrm{Al}(\mathrm{OH})_{3(\mathrm{~s})}+\mathrm{NaOH}_{(\mathrm{aq})} \rightarrow \mathrm{Na}^{+}+\mathrm{Al}(\mathrm{OH})_{4(\mathrm{aq})}^{-} \\
\mathrm{AlO}(\mathrm{OH})_{(\mathrm{s})}+\mathrm{NaOH}_{(\mathrm{aq})}+\mathrm{H}_{2} \mathrm{O} \rightarrow \mathrm{Na}^{+}+\mathrm{Al}(\mathrm{OH})_{4(\mathrm{aq})}^{-}
\end{gathered}
$$

\subsubsection{Clarification}

In this step, the insoluble residue is separated from the sodium aluminate solution. Finer residue is settled by the addition of synthetic coagulants such as polyacrylate and polyamides. The temperature of the clarified solution can be decreased in heat exchangers to change the degree of supersaturation of the dissolved alumina[1].

\subsubsection{Precipitation}

The clarified solution is pumped into precipitators and the seed crystals - aluminum hydroxide crystals - are added to the solution in the precipitators to accelerate crystal formation. The agglomerates of aluminum hydroxide crystals are filtered and washed to remove remaining caustic solution[1].

$$
\mathrm{Na}+\mathrm{Al}(\mathrm{OH})_{4(\mathrm{aq})}^{-} \rightarrow \mathrm{Al}(\mathrm{OH})_{3(\mathrm{~s})}+\mathrm{NaOH}_{(\mathrm{aq})}
$$

\subsubsection{Calcination}

The filtered aluminum hydroxide is calcined in a furnace at $960^{\circ} \mathrm{C}$ to produce commercially pure alumina[1].

$$
2 \mathrm{Al}(\mathrm{OH})_{3(\mathrm{~s})} \rightarrow \mathrm{Al}_{2} \mathrm{O}_{3(\mathrm{~s})}+3 \mathrm{H}_{2} \mathrm{O}_{(\mathrm{g})}
$$

\subsubsection{Lime - soda sintering process}

This process can be used for bauxite containing diaspore or low quality bauxite ore to produce alumina Figure 2-1b. However, high-energy consumption and environmental pollution are the 
drawbacks of this method compared to the Bayer process. In this process, limestone and caustic soda are mixed with crushed bauxite ores, then the mixture is sintered at high temperature to generate sodium aluminate which is dissolved in water or diluted alkaline for further processing.

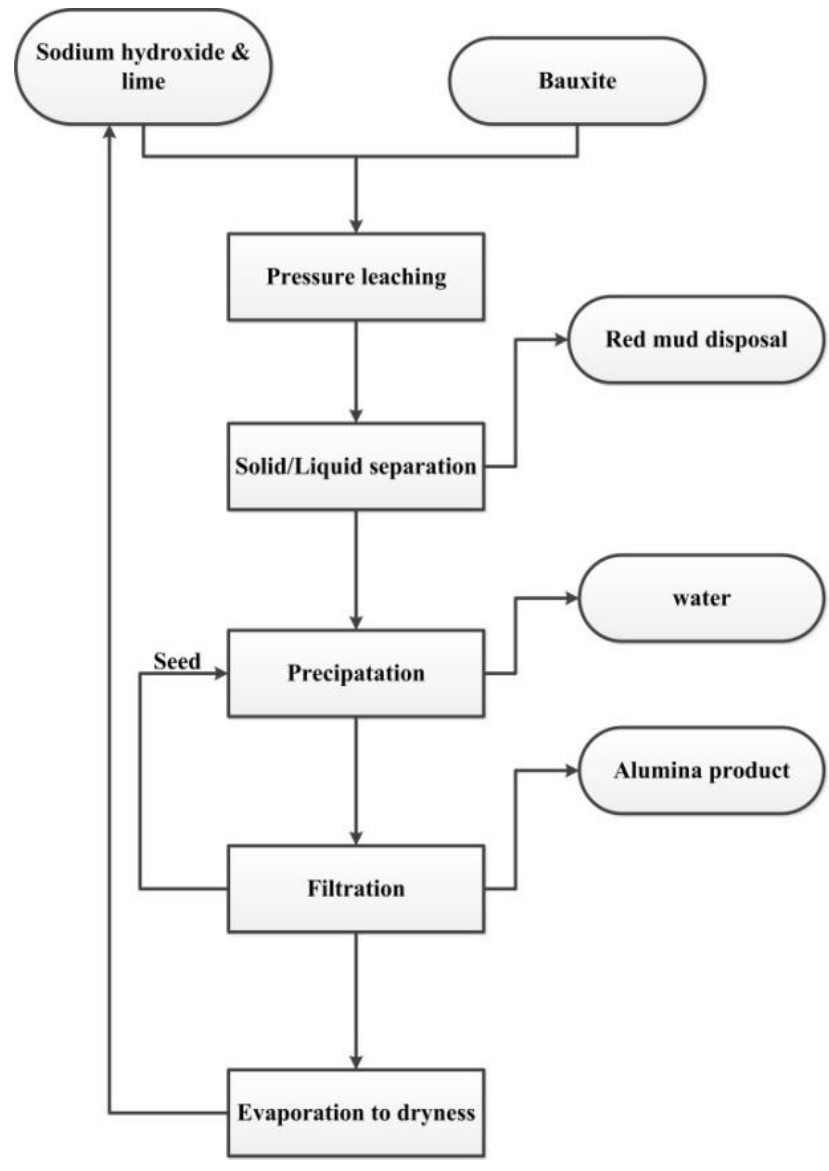

(a)

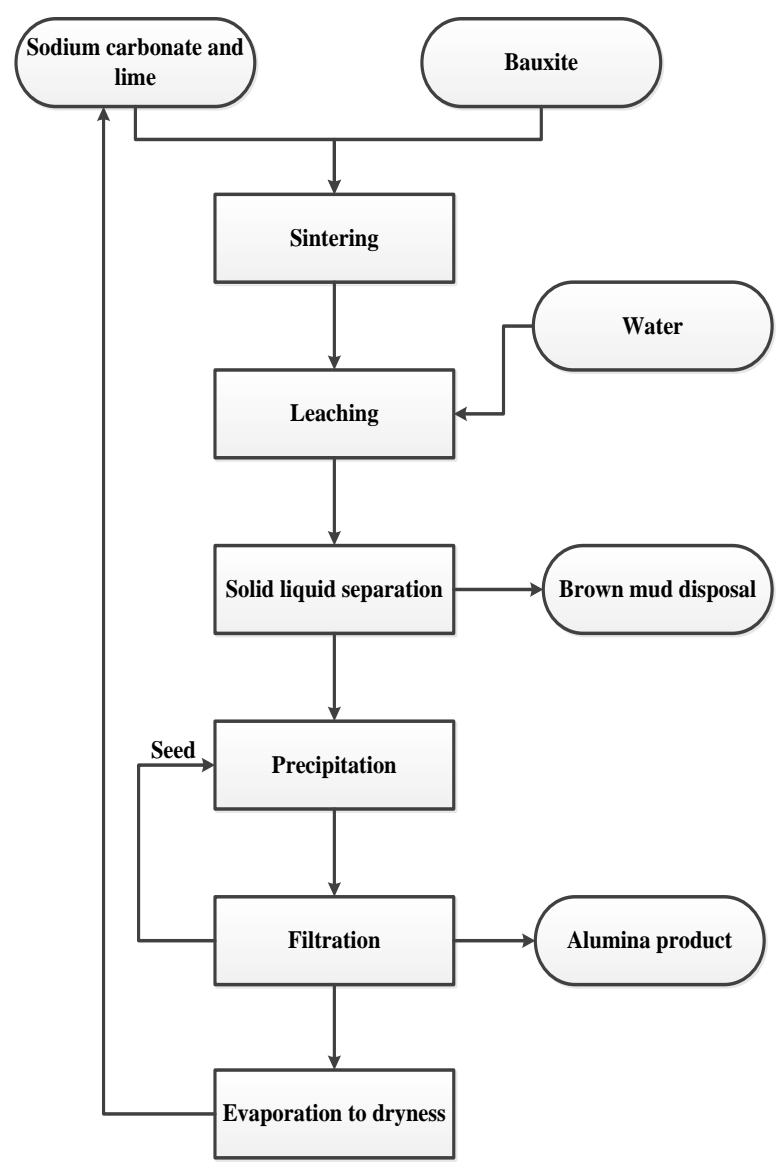

(b)

Figure 2-1: Alumina production flowcharts (a) Bayer process and (b) lime- soda sintering process

\subsection{Red mud}

Extraction of alumina from bauxite ore generates a significant amount of bauxite residue. The high concentration of iron containing minerals in this residue gives its characteristic red color and creates the so-called red mud. The chemical compositions and properties of red mud depend on the chemical and mineralogical composition of bauxite and the bauxite treatment technology used in the alumina production. 
As a global average, the production of 1 tonne of aluminum generates 2-3 tonnes of red mud. Presently, according to the global inventory, the accumulation of worldwide bauxite residue is estimated to be over 2.7 billion tonnes as a legacy of nearly 120 years of alumina extraction from bauxite ore and is increasing by more than 90 million tonnes yearly, Figure 2-2 [3].

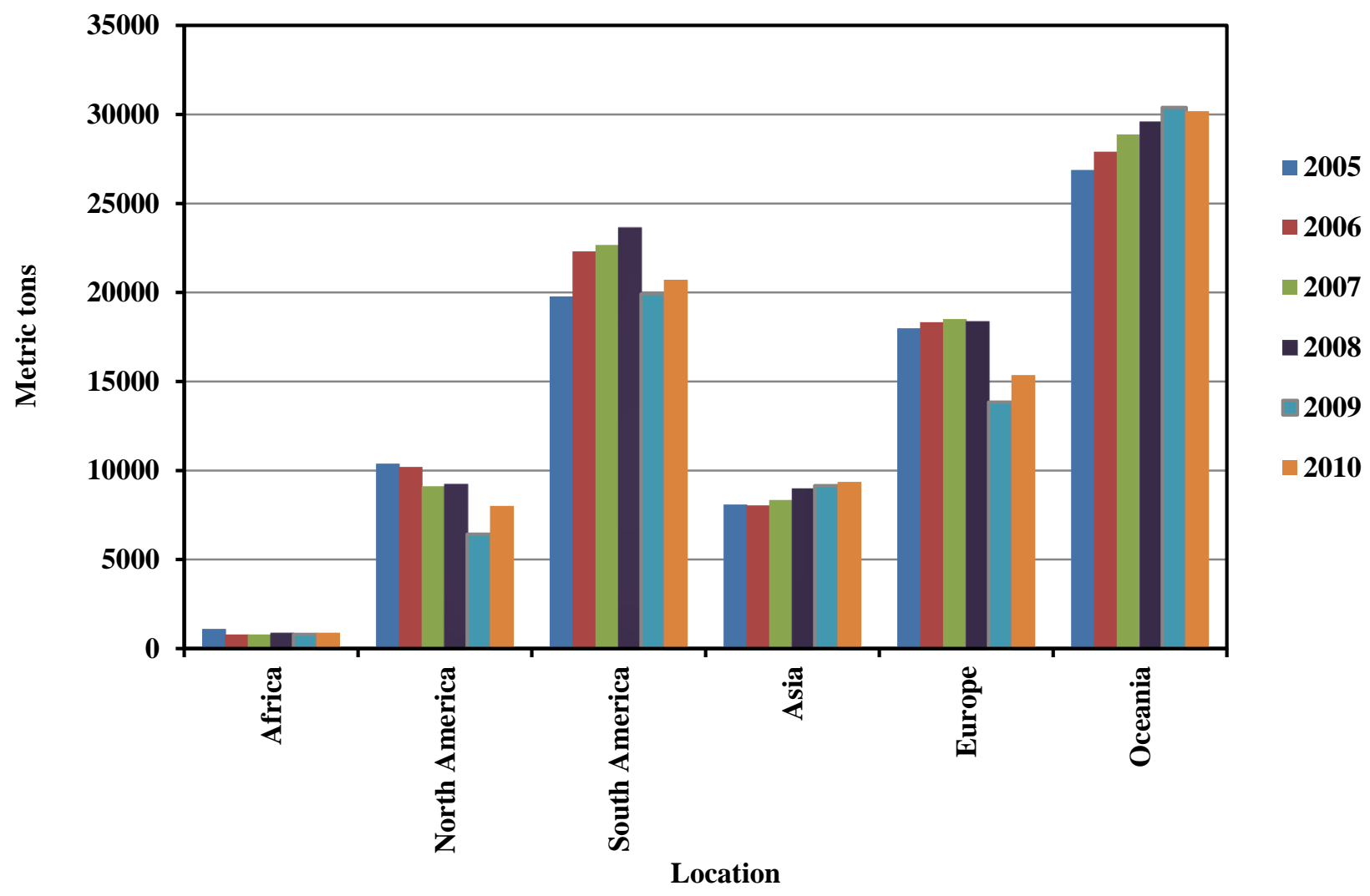

Figure 2-2: Accumulated bauxite residue (red mud) all over the world for 6 years [3]

\subsubsection{Chemical and mineralogical characteristics of red mud}

The mineralogy and chemical composition of the red mud depends on the quality of the bauxite and the refining process parameters. In general, the red mud consists of iron oxide, aluminum oxide, titanium oxide, sodium oxide, silicon oxide, and calcium oxide [4]. The chemical composition of red mud from selected plants is presented in Table 2-1. Like most ores and soils, bauxite can contain traces of metals such as arsenic, beryllium, cadmium, chromium, lead, manganese, nickel and naturally occurring radioactive materials, such as thorium and uranium. Most of these trace elements stay in the residue [4]. 
Table 2-1: Chemical composition of red muds from different operations (wt\%)

\begin{tabular}{ccccccccc}
\hline & $\begin{array}{c}\text { Australia } \\
{[5]}\end{array}$ & $\begin{array}{c}\text { Jamaica } \\
{[6]}\end{array}$ & $\begin{array}{c}\text { Spain } \\
{[5]}\end{array}$ & $\begin{array}{c}\text { Canada } \\
{[7]}\end{array}$ & $\begin{array}{c}\text { Germany } \\
{[5]}\end{array}$ & $\begin{array}{c}\text { Italy } \\
{[8]}\end{array}$ & $\begin{array}{c}\text { China } \\
{[9]}\end{array}$ & $\begin{array}{c}\text { China } \\
{[10]^{*}}\end{array}$ \\
\hline $\mathrm{Fe}_{2} \mathrm{O}_{3}$ & 34.8 & 49.5 & 37.5 & 31.6 & 44.8 & 46.1 & 36.2 & 12.3 \\
$\mathrm{Al}_{2} \mathrm{O}_{3}$ & 23.2 & 16.5 & 21.2 & 20.6 & 16.2 & 15.3 & 20.9 & 6.27 \\
$\mathrm{CaO}$ & 2.3 & 5.5 & 5.5 & 1.7 & 5.2 & 4.4 & 3.0 & 37.5 \\
$\mathrm{TiO}_{2}$ & 8.0 & 7.0 & 11.5 & 6.2 & 12.3 & 8.8 & 6.3 & 3.3 \\
$\mathrm{Na}_{2} \mathrm{O}$ & 7.1 & 7.0 & 2.3 & 10.3 & 4.0 & 6.4 & 12.7 & 2.8 \\
$\mathrm{SiO}_{2}$ & 9.2 & 3.0 & 4.4 & 8.9 & 5.4 & 8.3 & 15.9 & 17.8 \\
\hline
\end{tabular}

* Represent the sintering process of red mud

\subsubsection{Negative effects of red mud}

Red mud is categorized as a non-hazardous waste. However, because of the size of this waste stream and its causticity, the red mud disposal leads to important environmental concerns. At present, the red mud is disposed into sealed or unsealed artificial ponds close to the extraction plant, and therefore a considerable amount of land is required. Hence, water with caustic sodium compounds and other toxic materials from the red mud can penetrate to the ground and contaminate ground waters, damage ground cover in large areas, and affect ecosystems. There is also the possibility of leaks and flood, such as red mud spill in 2010 in the Hungarian town of Akja, when the burst of a retaining wall following a period of heavy rain, released one million cubic meters of the toxic red sludge to the surrounding area, killing 10 people and injuring several hundred Figure 2-3. 

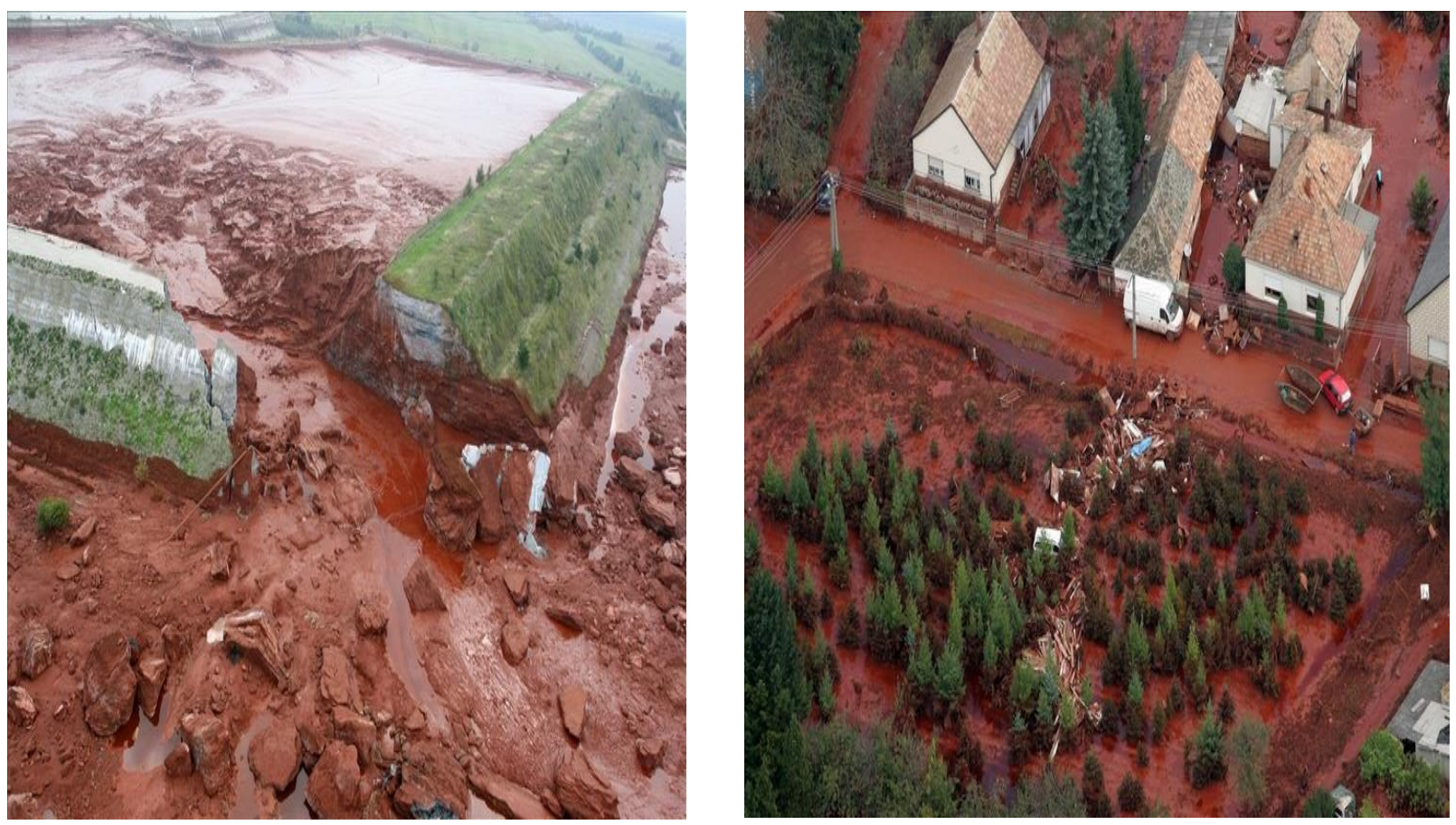

Figure 2-3: The red mud catastrophe in Hungary, October 2010 (Air photo by Digital Globe)

\subsubsection{The possible applications of red mud}

In spite of the environmental concern of this large waste stream and the exploitation possibilities of red mud for further processing, red mud has never been satisfactorily utilized as a by-product despite 50 years of research and hundreds of related patents and publications. Available potential options for utilization of red mud including the process and final products are summarized in Table 2-2.

In order to successfully convert bauxite residue into a product of value, it will be necessary to overcome the technological and ecological complications. Since red mud contains a significant amount of valuable oxides, a possible application could be in steelmaking industry [11]. Thus, this project is aimed at generating more information and understanding about utilization of red mud as a refining flux in steel manufacturing for desulphurization and dephosphorization of liquid iron during pretreatment of hot metal. 
Table 2-2: Red mud utilization possibilities

\begin{tabular}{|c|c|c|c|}
\hline Application & Processes & Product & Reference \\
\hline \multirow{2}{*}{$\begin{array}{l}\text { An agricultural } \\
\text { modification for } \\
\text { improvement of } \\
\text { sandy soils }\end{array}$} & Addition to soil & Improvement of soil properties & \multirow{2}{*}[4,12-14]{} \\
\hline & $\begin{array}{l}\text { Neutralization, } \\
\text { adsorption }\end{array}$ & $\begin{array}{l}\text { Remediation of soil, re- } \\
\text { vegetation }\end{array}$ & \\
\hline \multirow{3}{*}{$\begin{array}{l}\text { Material for } \\
\text { construction } \\
\text { purposes (e.g., } \\
\text { cement, road fill, } \\
\text { brick making) }\end{array}$} & $\begin{array}{l}\text { Drying, sintering, } \\
\text { annealing }\end{array}$ & Production of cements & \multirow{3}{*}[4,9,14-18]{} \\
\hline & Addition & Production of concrete fillers & \\
\hline & $\begin{array}{l}\text { Drying, pressing, } \\
\text { firing, granulation }\end{array}$ & $\begin{array}{l}\text { Brick production and } \\
\text { aggregates of special concretes }\end{array}$ & \\
\hline \multirow{2}{*}{$\begin{array}{l}\text { Source of raw } \\
\text { materials for glass } \\
\text { - ceramic }\end{array}$} & $\begin{array}{l}\text { Drying, pelletisation, } \\
\text { annealing }\end{array}$ & $\begin{array}{l}\text { Ceramic manufacturing, } \\
\text { ceramic glazes }\end{array}$ & \multirow{2}{*}[4,8,14,19-22]{} \\
\hline & Addition & Glass manufacturing & \\
\hline $\begin{array}{l}\text { Feedstock for } \\
\text { mineral production }\end{array}$ & $\begin{array}{l}\text { Drying, reduction, } \\
\text { leaching }\end{array}$ & $\begin{array}{l}\text { Production of } \mathrm{Fe}_{2} \mathrm{O}_{3}, \mathrm{Al}_{2} \mathrm{O}_{3} \text {, } \\
\mathrm{TiO}_{2}\end{array}$ & {$[4,14,23-25]$} \\
\hline \multirow{3}{*}{$\begin{array}{l}\text { Applications of red } \\
\text { mud in waste } \\
\text { water treatment }\end{array}$} & Adsorption & $\begin{array}{l}\text { Removing of undesirable } \\
\text { components }\end{array}$ & \multirow{3}{*}[4,14,26-29]{} \\
\hline & Chemical treatment & Filtration material & \\
\hline & Coagulation & Coagulant & \\
\hline \multirow{2}{*}{$\begin{array}{l}\text { Neutralizing } \\
\text { treatment material } \\
\text { for acidic mining } \\
\text { wastes }\end{array}$} & Chemical treatment & Filtration material & \multirow{2}{*}[4,5,14]{} \\
\hline & Adsorption & $\begin{array}{l}\text { Neutralization of acid mine } \\
\text { drainage }\end{array}$ & \\
\hline
\end{tabular}




\subsection{Hot metal}

In the steel industry, the blast furnace/converter combination is still the dominant route for making iron. The blast furnace is a metallurgical unit that utilizes coke, limestone and iron ore to produce liquid iron, which is known as hot metal or pig iron. The molten iron is separated from the liquid slag and treated to reduce the content of impurity elements such as sulphur, silicon, and phosphorus.

The chemical composition of hot metal can be varied depending on the composition of the ore charged in the blast furnace, and the method of furnace operation. The chemical compositions of typical hot metal (pig iron) grades are shown in Table 2-3.

Table 2-3: Typical hot metal composition [30]

\begin{tabular}{|c|c|c|c|c|c|}
\hline Type of hot metal & wt\% C & wt\% Si & wt\% Mn & wt\% P & wt\% S \\
\hline Low-phosphorus & $4.0-4.5$ & $0.30-0.70$ & $0.20-0.70$ & $0.05-0.12$ & $0.03-0.06$ \\
\hline High-phosphorus & $3.2-4.0$ & $0.30-0.70$ & $0.25-1.20$ & $1.5-2.20$ & $0.03-0.06$ \\
\hline Foundry & $3.5-4.2$ & $1.8-2.5$ & $0.70-1.00$ & $0.50-0.70$ & $0.03-0.06$ \\
\hline
\end{tabular}

Phosphorus and sulphur are the two most deleterious impurity elements found in hot metal. Phosphorus increases the tendency toward cold shortness in steel. It also makes the steel prone to temper embrittlement during heat treatment. Therefore, lowering phosphorus content in steel is a necessary step for all applications requiring steel with high deformability [31].

Sulphur improves machinability, but cannot be used in steel unless there is sufficient manganese to combine with it to form manganese sulphide. If manganese is not present, sulphur forms a low melting iron sulphide network around the austenite grain boundaries. Steel with this structure is very weak and brittle at hot working temperatures (900-1100 ${ }^{\circ} \mathrm{C}$ ) and this phenomenon is called hot shortness. Manganese sulphide exist as an isolated phase, rather than network, and acts as an internal lubricant and chip breaker. Internal lubricants reduce friction and wear between tool and work-piece and tool and chip. Table 2-4 shows a summary of the effect of phosphorus and sulphur on steel properties [32]. 
Table 2-4: Typical effects of phosphorus and sulphur in steel [32]

\begin{tabular}{|c|c|c|}
\hline Property & Effect of phosphorus & Effect of sulphur \\
\hline Strength & ++ & - \\
\hline Bake hardenability & +- & Low melting FeS: Hot shortness \\
\hline Ductility & -+ & MnS: internal lubricant and chip breaker \\
\hline Machinability & - Can improve resistance to \\
powdering. & \\
\hline Fe-Zn Galvanneal & \begin{tabular}{c} 
\\
\hline Phosphatability
\end{tabular} & - \\
\hline Fracture toughness & - & \\
\hline $\begin{array}{c}\text { Weldability } \\
\text { Stress corrosion } \\
\text { cracking }\end{array}$ & Not harmful up to $\sim 0.1 \mathrm{wt} \%$ & \\
\hline
\end{tabular}

+ Increase $\quad++$ Strong increase $\quad-$ Decrease $\quad-\quad$ Strong decrease

\subsubsection{Pretreatment of hot metal}

Today, the most common process for steelmaking is the integrated steelmaking process: The blast furnace ironmaking is followed by the hot metal pretreatment, decarburization in a BOF (Basic Oxygen Furnace) and secondary refining. Hot metal pretreatment involves the removal of impurity elements such as silicon, phosphorus and sulphur. Hot metal is then decarburized and converted to steel in the BOF using an oxygen blowing process. The molten steel tapped from BOF is subjected to further refining and degassing in a processing step known as secondary refining.

The hot metal pretreatment process was developed by the Japanese steel industry in the early 1980s. Meanwhile, several similar processes have been adopted within the industry to improve cost-effectiveness by decreasing the amount of disposed slag (as a result of its impact on the environment), lowering the extent of refractory wear and increasing the steel yield [31].

Hot metal pretreatment involves desiliconization, dephosphorization, and desulphurization reactions. The desiliconization step can reduce the silicon content to less than $0.2 \mathrm{wt} \%$ to 
improve the efficiency of the following stages for phosphorus and sulphur removal. Common procedures for hot metal desiliconization are listed in Table $2-5$.

Table 2-5: Processes and fluxes for desiliconization [31]

\begin{tabular}{ccc}
\hline Process & Regent usage & Efficiency \% \\
\hline $\begin{array}{c}\text { Mill scale and lime added to } \\
\text { BF runner }\end{array}$ & $\begin{array}{c}15-25 \mathrm{~kg} \mathrm{t}^{-1} \text { mill scale } \\
8-10 \mathrm{~kg} \mathrm{t}^{-1} \text { lime }\end{array}$ & $80-90$ \\
$\begin{array}{c}\text { Mill scale added to transfer } \\
\text { ladle }\end{array}$ & $32 \mathrm{~kg} \mathrm{t}^{-1}$ mill scale & $60-80$ \\
$\begin{array}{c}\text { Mill scale injection into } \\
\text { torpedo car }\end{array}$ & $15-25 \mathrm{~kg} \mathrm{t}^{-1}$ mill scale \\
$\begin{array}{c}\text { Oxygen blowing into torpedo } \\
\text { car } \\
\begin{array}{c}\text { Deep oxygen injection into } \\
\text { transfer ladle }\end{array}\end{array}$ & $0.13 \mathrm{Nm}^{-1} \mathrm{t}^{-1}$ & $40-60$ \\
\hline
\end{tabular}

After desiliconization and deslagging, dephosphorization and desulphurization steps are carried out by injection of an oxidizing agent using a carrier gas such as nitrogen or air, and in some cases top or bottom oxygen blowing. Typical fluxes and different processes, which are used in this step, are listed in Table 2-6. Low sulphur steels can be produced by further desulphurization through injection of more reactive agents [31]

Table 2-6: Common processes and fluxes for dephosphorization and desulphurization [31]

\begin{tabular}{|c|c|c|c|c|c|c|c|}
\hline \multirow[b]{2}{*}{ Process } & \multirow[b]{2}{*}{ Vessel } & \multirow[b]{2}{*}{ Flux mixture, wt $\%$} & \multirow[b]{2}{*}{$\mathrm{Kg}^{-1}$} & \multicolumn{2}{|c|}{$\mathrm{wt} \% \mathrm{P}$} & \multicolumn{2}{|c|}{$\mathrm{wt} \% \mathrm{~S}$} \\
\hline & & & & Before & After & Before & After \\
\hline Injection with $\mathrm{N}_{2}$ & $\begin{array}{l}\text { Torpedo } \\
\text { car }\end{array}$ & $\begin{array}{c}35 \mathrm{CaO}, 55 \mathrm{mill} \\
\text { scale, } 5 \mathrm{CaF}_{2}, 5 \\
\mathrm{CaCl}_{2}\end{array}$ & 52 & 0.10 & 0.015 & 0.025 & 0.005 \\
\hline $\begin{array}{l}\text { Injection with } \mathrm{N}_{2}, \mathrm{O}_{2} \\
\text { top blowing }\end{array}$ & $\begin{array}{l}\text { Torpedo } \\
\text { car }\end{array}$ & $\mathrm{Na}_{2} \mathrm{CO}_{3}$ & 20 & 0.09 & 0.020 & 0.060 & 0.01 \\
\hline $\begin{array}{l}\mathrm{Na}_{2} \mathrm{CO}_{3} \text { top addition } \\
\mathrm{O}_{2} \text { top blowing }\end{array}$ & Ladle & $\mathrm{Na}_{2} \mathrm{CO}_{3}$ & 20 & 0.10 & 0.010 & 0.030 & 0.005 \\
\hline Injection with $\mathrm{N}_{2}$ & Ladle & $\begin{array}{c}30 \mathrm{CaO}, 62 \text { sinter } \\
\text { fine, } 4 \mathrm{CaF}_{2}, 4 \\
\mathrm{CaCl}_{2}\end{array}$ & 45 & 0.12 & 0.010 & 0.025 & 0.01 \\
\hline $\begin{array}{l}\text { Injection with } \mathrm{N}_{2}, \mathrm{O}_{2} \\
\text { top blowing }\end{array}$ & Ladle & $\begin{array}{l}38 \mathrm{CaO}, 42 \text { sinter } \\
\text { fine, } 20 \mathrm{CaF}_{2}\end{array}$ & 40 & 0.10 & 0.010 & 0.040 & 0.02 \\
\hline $\mathrm{O}_{2}$ top blowing & Q-BOP & $\begin{array}{l}39 \mathrm{CaO}, 55 \text { sinter } \\
\text { fine, } 6 \mathrm{CaF}_{2}\end{array}$ & 51 & 0.14 & 0.010 & 0.020 & 0.01 \\
\hline
\end{tabular}


The overall economic benefits of hot metal pretreatment depend on the availability and relative cost of raw materials, steel scrap and hot metal. Today, using fully refined hot metal in BOF charge is neither practical nor cost-effective in most steel plants outside of Japan. Hot metal pretreatment in the European and North American steel plants is confined to desulphurization in the transfer ladle with injection of materials such as lime, calcium carbide, soda ash, magnesium, and fluxes containing these elements and compounds.

\subsection{Physicochemical properties of fluxes}

In order to understand the efficiency of the treatments of liquid metal under slag, many efforts have been made by researchers to evaluate the physicochemical properties of slags.

Flux, is the substance added to molten metals in order to help separate its bonds with impurities which can then be readily removed (known as slag). "Slag consists mostly of mixed oxides of elements such as silicon, sulphur, phosphorus, and aluminum; ash; and products formed in their reactions with furnace linings and fluxing substances such as limestone" [33]. Slags play an important role in metal production. In metallurgical industries, slags are found in various processing routes and serve different purposes. Metallurgical slags are usually based on the $\mathrm{CaO}$ $\mathrm{Al}_{2} \mathrm{O}_{3}-\mathrm{SiO}_{2}$ system. Practically, liquid slags can be used for different purposes such as covering the surface of liquid metal to prevent oxidation, and absorbing undesirable elements and inclusions from the liquid metal.

\subsubsection{Structural aspects of molten slags}

Essentially, physicochemical properties of molten slag can be controlled by their structure. Many theories of molecular and ionic structure have been suggested to define slag properties[34]. According to the molecular theory, liquid slag is composed of separate oxides such as $\mathrm{SiO}_{2}$, $\mathrm{Al}_{2} \mathrm{O}_{3}, \mathrm{FeO}$, and $\mathrm{CaO}$. However, electric conductivity behaviours have shown that molten slags are usually ionic conductors $[31,34]$. Thus, the molten slags are made up of ions and ions are involved in reactions between metal and slag.

In this definition, liquid slags consist of cations (e.g., $\mathrm{Mg}^{2+}, \mathrm{Ca}^{2+}$ and $\mathrm{Fe}^{2+}$ ), anions (e.g., $\mathrm{O}^{2-}, \mathrm{F}^{2-}$ and $\mathrm{S}^{2-}$ ) and anion complexes such as $\mathrm{SiO}_{4}{ }^{4-}, \mathrm{PO}_{4}{ }^{3-}$, and $\mathrm{AlO}_{3}{ }^{3-}$ [34]. Moreover, molten slag contains silica and/or other complex constituents. Silicate slags are three-dimensional 
arrangements with $\mathrm{Si}^{4+}$ (cations) surrounded by four oxygen anions $\left(\mathrm{O}^{2-}\right)$ and form a tetrahedron. When each $\left(\mathrm{O}^{-2}\right)$ is connected to two $\mathrm{Si}^{4+}$ ions, (bridging $\mathrm{O}$ ), this causes the formation of a 3-D array structure.

The silicate tetrahedron $\mathrm{SiO}_{4}{ }^{4-}$ can be defined as the fundamental building unit in solid silica and molten silicate. The silicate units are joined together in chains to introduce a large polymerized network of silicate anions Figure 2-4.

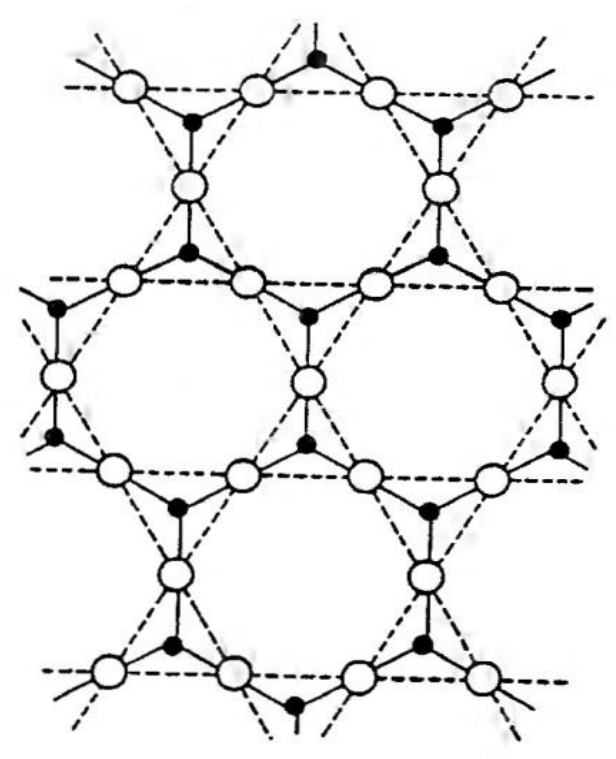

a

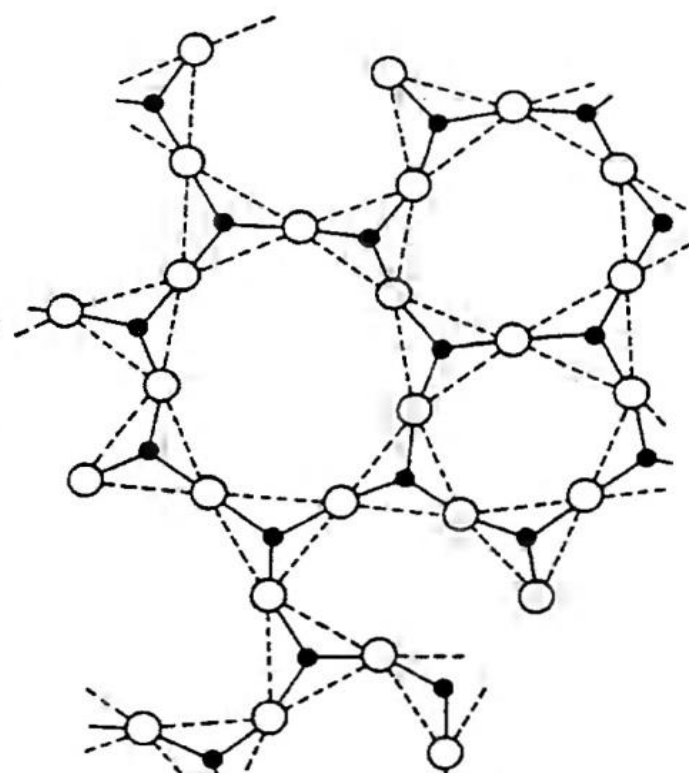

b

Figure 2-4: Two dimensional schematic representation of (a) crystalline and (b) molten silica [31]

The addition of basic oxides (e.g., $\mathrm{FeO}, \mathrm{CaO}, \mathrm{MnO}$ ) to molten silica results in their dissociation into metallic cations and oxygen anions. This oxygen anion bonds with $\mathrm{SiO}_{2}$ in the silica structure and brings about a breakdown of the silicate network with an increasing degree of depolymerisation. In fact, some of the oxygen atoms are connected between two silicon atoms (i.e., bridging oxygen $\left[\mathrm{O}^{\circ}\right]$ ), and some to only one silicon atom (i.e., they act as a non-bridging oxygen $\left.\left[\mathrm{O}^{-}\right]\right)$. The partial depolymerization of the silicate network is shown in Figure 2-5a. The silicate network can be completely depolymerized to single $\mathrm{SiO}_{4}{ }^{4-}$ tetrahedra and cation (e.g., $\mathrm{Ca}$, $\mathrm{Fe}, \mathrm{Mn})$ and some free oxygen ions $\left(\mathrm{O}^{2-}\right)$ by addition of more basic oxide Figure 2-5b.

The silicate network theory can be applied to explain the physicochemical properties of molten slag such as viscosity. In molten slag the size of the silica and aluminisilicate network increases 
with increasing $\mathrm{Al}_{2} \mathrm{O}_{3}$ and $\mathrm{SiO}_{2}$ and results in a higher viscosity due to polymerization of the silicate network. The addition of metal oxide brings about a breakdown of the silicate network, resulting in lower viscosity [31].

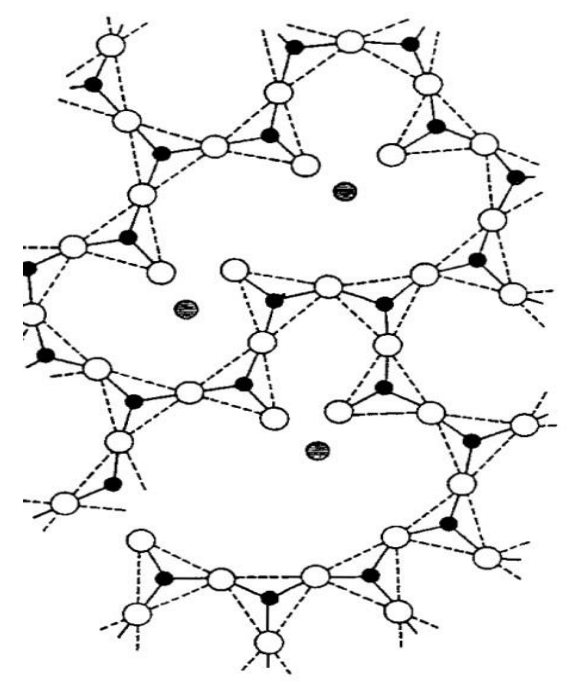

$\mathrm{a}$

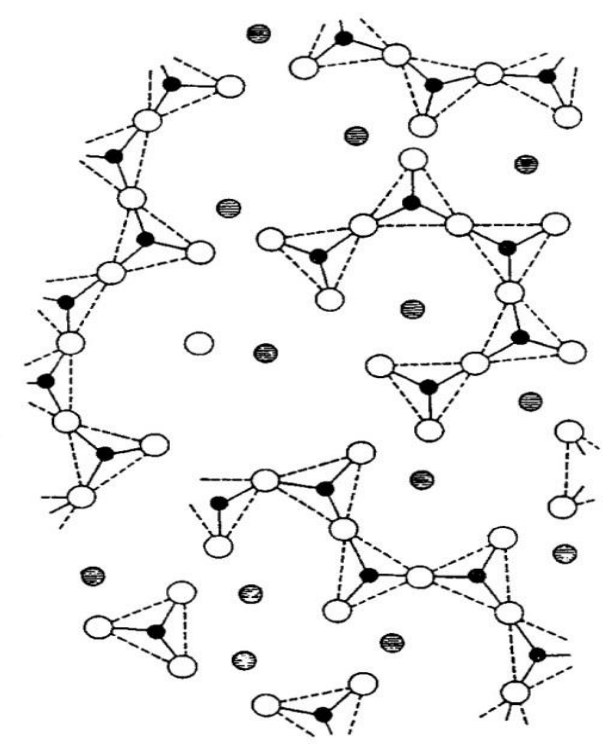

b

Figure 2-5: Schematic structural of depolymerization of silicate network with the addition of a basic oxide [31]

\subsubsection{Basicity definition}

Defining basicity is essential to characterize the composition and properties of slags in a simple and practical manner. There are two approaches to defining basicity of slags. One is a simple ratio of concentration of basic to acidic components, and the other is the activity of the free oxygen ions in the slag [35].

\subsubsection{Common basicity indices}

From the first approach, the general equation for slag basicity can be simplified by the following expression:

$\mathrm{B}=\frac{\% \mathrm{CaO}}{\% \mathrm{SiO}_{2}}$

This ratio is simple, but does not take into account the effect of oxides other than $\mathrm{CaO}$ and $\mathrm{SiO}_{2}$ $\left(\mathrm{MgO}, \mathrm{Al}_{2} \mathrm{O}_{3}, \mathrm{FeO}\right.$, etc.) which are often present in slag in large quantities. Many suggestions 
have been made to establish more inclusive measures for slag basicity, several of which are listed in Table 2-7.

Table 2-7: Typical expressions for basicity [34]

\begin{tabular}{|c|}
\hline$\frac{\%(\mathrm{CaO})}{\%\left(\mathrm{SiO}_{2}\right)+\%\left(\mathrm{Al}_{2} \mathrm{O}_{3}\right)}$ \\
$\frac{\%(\mathrm{CaO})}{\%\left(\mathrm{SiO}_{2}\right)+\%\left(\mathrm{P}_{2} \mathrm{O}_{5}\right)}$ \\
$\frac{\%(\mathrm{CaO})+1.4 \%\left(\mathrm{MgO}_{2}\right)+0.84 \%\left(\mathrm{P}_{2} \mathrm{O}_{5}\right)}{\%(\mathrm{CaO})-1.86 \%\left(\mathrm{SiO}_{2}\right)-1.19 \%\left(\mathrm{P}_{2} \mathrm{O}_{5}\right)}$ \\
\hline $\mathrm{x}(\mathrm{CaO})+\frac{0.5 \mathrm{x}(\mathrm{MgO})}{\mathrm{x}\left(\mathrm{SiO}_{2}\right)}+0.33\left(\mathrm{Al}_{2} \mathrm{O}_{3}\right)$ \\
\hline
\end{tabular}

\subsubsection{Optical basicity}

The second approach in the ionic theory of slags is the activity of the free oxygen ion, $a\left(\mathrm{O}^{2-}\right)$. Essentially, basicity of a slag can be increased by increasing the quantity of basic oxides. Basic oxides tend to dissociate into a cation and oxygen ion (i.e., when the concentration of free oxygen ion $\left[\mathrm{O}^{2-}\right]$ increases, so does the basicity), although, the thermodynamic activity of the oxygen ion $\left(\mathrm{O}^{2-}\right)$ cannot be determined.

The concept of optical basicity was developed by two glass scientists Duffy and Ingram[36] and introduced to the metallurgical community by Duffy, Ingram and Sommerville in the late seventies [37]. Duffy and Ingram suggested that optical basicity corresponds to the electron donor power of the oxygen ions in glass [36]. They showed experimentally that the shift in frequency of the ultraviolet (UV) spectral of probe ions such as $\mathrm{Pb}^{2+}$ may be used as a measure of the electron donor power of the oxide ions which is commonly expressed in terms of the optical basicity $(\Lambda)$ by using the following equation:

$\Lambda_{\mathrm{i}}=\frac{v_{\text {free }}-v_{\text {slag }}}{v_{\text {free }}-v_{\mathrm{CaO}}}$

Where: $v_{\text {free }}, v_{\text {sample }}$, and $v_{C a O}$ are shift in peak frequencies for $P b^{2+}, \mathrm{Pb}^{2+}$ in a slag and $P b^{2+}$ in $\mathrm{CaO}$, respectively. By definition, the optical basicity value is 1 for pure $\mathrm{CaO}$. 
Duffy and Ingram [36] indicated that optical basicity value can be calculated from the Pauling electronegativity number. They introduced a simple formula from the data of materials with known optical basicity, and formulated a relationship between lambda (optical basicity of an oxide $\Lambda_{\mathrm{i}}$ ) and Pauling's electronegativity of the cation, $\mathrm{x}$, which is shown below in Equation 2-7.

$\Lambda_{\mathrm{i}}=0.74 /(\mathrm{x}-0.26)$

In comparison, the average electron density scale was suggested by Nakamura et al. [38, 39] for optical basicity assessment. The obtained optical basicity values for some oxides calculated from Pauling's electronegativities and from average electron density are listed in Table 2-8. Although the two values are in good agreement for most oxides, they do not match for the transition metal oxides. Summerville and Yang [40] proposed that the average electron density gives a more accurate value for the transition metal oxides and suggested a list of recommended optical basicity values as shown in Table $2-8$.

For multi-component slags, the optical basicity can be calculated using the following relationships:

$$
\begin{aligned}
& \Lambda=\sum_{\mathrm{i}=1}^{\mathrm{n}} \Lambda_{\mathrm{i}} \mathrm{N}_{\mathrm{i}} \\
& \mathrm{N}_{\mathrm{i}}=\frac{\mathrm{X}_{\mathrm{i}} n_{\mathrm{O}_{\mathrm{i}}}}{\sum_{\mathrm{i}=1}^{\mathrm{n}} \mathrm{X}_{\mathrm{i}} n_{\mathrm{O}_{\mathrm{i}}}}
\end{aligned}
$$

Where:

$$
\begin{array}{ll}
\Lambda_{\mathrm{i}}: & \text { Optical basicity of oxide component " } \mathrm{i} \text { " } \\
\Lambda: & \text { Optical basicity of a multicomponent slag } \\
\mathrm{N}_{\mathrm{i}}: & \text { Compositional fraction } \\
\mathrm{X}_{\mathrm{i}}: & \text { Mole fraction of component " } \mathrm{i} \text { " in the slag } \\
n_{O_{i}}: & \text { Number of oxygen atoms in component " } \mathrm{i} \text { " }
\end{array}
$$

The optical basicity approach has proved to be a valuable tool for designing slags or fluxes which will have the required characteristics with respect to the behavior of different components such as sulphur, phosphorus, hydrogen, magnesia and alkalies [40-43]. 
Table 2-8: Values of optical basicity of some oxides from different sources [44]

\begin{tabular}{lccc}
\hline Oxide & $\begin{array}{c}\text { Optical basicity calculated from } \\
\text { Pauling electronegativity* }\end{array}$ & $\begin{array}{c}\text { Optical basicity calculated } \\
\text { from electron density** }\end{array}$ & $\begin{array}{c}\text { Recommended optical } \\
\text { basicity*** }\end{array}$ \\
\hline $\mathrm{K}_{2} \mathrm{O}$ & 1.04 & 1.15 & 1.40 \\
$\mathrm{Na}_{2} \mathrm{O}$ & 1.15 & 1.10 & 1.20 \\
$\mathrm{BaO}$ & 1.15 & 1.08 & 1.10 \\
$\mathrm{CaO}$ & 1.00 & 1.00 & 1.00 \\
$\mathrm{MnO}$ & 0.59 & 0.95 & 0.95 \\
$\mathrm{FeO}$ & 0.51 & 0.93 & 0.93 \\
$\mathrm{MgO}$ & 0.78 & 0.92 & 0.85 \\
$\mathrm{Fe}_{2} \mathrm{O}_{3}$ & 0.48 & 0.69 & 0.69 \\
$\mathrm{Al}_{2} \mathrm{O}_{3}$ & 0.61 & 0.68 & 0.65 \\
$\mathrm{TiO}_{2}$ & 0.61 & 0.64 & 0.65 \\
$\mathrm{SiO}_{2}$ & 0.48 & 0.47 & 0.48 \\
$\mathrm{P}_{2} \mathrm{O}_{5}$ & 0.40 & 0.38 & 0.40 \\
\hline
\end{tabular}

*: Duffy and Ingram [36] $\quad$ **: Nakamura et al. [38, 39] ***: Summerville and Yang [40]

\subsection{Desulphurization}

Practically, different fluxes can be used to remove sulphur from liquid metal. Sulphur dissolves into molten fluxes as sulphide ions $\left(\mathrm{S}^{2-}\right)$ in reducing conditions $\left(\mathrm{P}_{\mathrm{O}_{2}}\right.$ less than $\left.10^{-6} \mathrm{~atm}\right)$, and as sulphate ions $\left(\mathrm{SO}_{4}^{-}\right)$under highly oxidizing conditions. However, the oxygen potential in the steelmaking process is not high enough for sulphur to dissolve as sulphate ions in molten fluxes[31]. The desulphurization phenomenon occurring in molten fluxes can be evaluated by either the sulphide capacity or sulphur partition ratio. The sulphide capacity is the ability of a liquid flux to hold sulphur in solution at equilibrium conditions with a liquid metal or gas. The sulphur partition ratio shows the ratio of sulphur in flux to sulphur in metal phase. 


\subsubsection{Thermodynamics of desulphurization}

\subsubsection{Sulphide capacity and sulphur partition ratio}

Fundamentally, the solubility of sulphur in the steelmaking process has two important reactions [45] for the equilibrium in slag-metal and slag-gas systems respectively:

$[\mathrm{S}]+\left(\mathrm{O}^{2-}\right)=\left(\mathrm{S}^{2-}\right)+[\mathrm{O}]$

$\frac{1}{2} \mathrm{~S}_{2}(\mathrm{~g})+\left(\mathrm{O}^{2-}\right)=\left(\mathrm{S}^{2-}\right)+\frac{1}{2} \mathrm{O}_{2}(\mathrm{~g})$

The equilibrium constant for reactions 2-10 and 2-11 are represented by Equations 2-12 and 2-13 correspondingly:

$\mathrm{K}_{1}=\frac{\mathrm{a}_{\mathrm{S}^{2-}}}{\mathrm{a}_{\mathrm{O}^{2-}}} \cdot \frac{\mathrm{h}_{\mathrm{O}}(1 \mathrm{wt} \%)}{\mathrm{h}_{\mathrm{S}}(1 \mathrm{wt} \%)}$

$\mathrm{K}_{2}=\frac{\mathrm{a}_{\mathrm{S}^{2-}}}{\mathrm{a}_{\mathrm{O}^{2-}}} \cdot\left(\frac{\mathrm{P}_{\mathrm{O}_{2}}}{\mathrm{P}_{\mathrm{S}_{2}}}\right)^{\frac{1}{2}}$

Where: $a_{0^{2-}}$ and $a_{\mathrm{S}^{2-}}$ are the activities of sulphur and oxygen ions in slag phase.

$\mathrm{P}_{\mathrm{O}_{2}}$ and $\mathrm{P}_{\mathrm{S}_{2}}$ are the partial pressures of $\mathrm{S}_{2}(\mathrm{~g})$ and $\mathrm{O}_{2}(\mathrm{~g})$.

$h_{S}(1 w t \%)$ and $h_{0}(1 w t \%)$ are the activities of sulphur and oxygen in liquid iron according to the one weight percent standard state.

With respect to the one weight percent standard state, the activity of sulphur in iron is defined by:

$\mathrm{h}_{\mathrm{S}}(1 \mathrm{wt} \%)=\mathrm{f}_{\mathrm{S}}(1 \mathrm{wt} \%) \cdot[\mathrm{wt} \% \mathrm{~S}]_{\text {metal }}$

Where: $f_{\mathrm{S}}(1 \mathrm{wt} \%)$ is the activity coefficient of sulphur based on the one weight percent standard state.

For infinitely dilute solutions, the activity of sulphur in the slag phase $\left(a_{\mathrm{S}^{2-}}\right)$ is proportional to the concentration and can be defined as: 
$\mathrm{a}_{\mathrm{S}^{2-}}=\mathrm{N}_{\mathrm{S}^{2-}} \cdot \gamma_{\mathrm{S}^{2-}}$

$\mathrm{N}_{\mathrm{S}^{2-}}=\frac{\mathrm{n}_{\mathrm{S}^{2-}}}{\sum \mathrm{n}}$

Where: $\gamma_{S^{2-}}$ is the activity coefficient of sulphur in the slag and $n_{S^{2-}}$ is the number of mols of sulphur and $\mathrm{n}$ total number of mols.

Since the slag composition is reported in mass percent, $\mathrm{n}_{\mathrm{S}^{2-}}$ per $100 \mathrm{~g}$ of the substance is given by the ratio:

$\mathrm{n}_{\mathrm{S}^{2-}}=\frac{(\mathrm{wt} \% \mathrm{~S})}{\mathrm{M}_{\mathrm{S}}}$

With the atomic mass of sulphur being $32 \mathrm{~g} / \mathrm{mol}$, the activity of sulphur in the slag phase, $a_{\mathrm{S}^{2-}}$, can be defined by a simplified equation:

$\mathrm{a}_{\mathrm{S}^{2-}}=(\mathrm{wt} \% \mathrm{~S}) \cdot \mathrm{C} \cdot \gamma_{\mathrm{S}^{2-}}$

Where:

$\mathrm{C}=\frac{1}{32 \sum \mathrm{n}}$

Therefore the equilibrium constants in Equations 2-12 and 2-13 can be rewritten as:

$\mathrm{K}_{1}=\frac{(\mathrm{wt} \% \mathrm{~S}) \mathrm{C} \gamma_{\mathrm{S}^{2-}}}{\mathrm{a}_{\mathrm{O}^{2-}}} \cdot \frac{\mathrm{h}_{\mathrm{O}}(1 \mathrm{wt} \%)}{[\mathrm{wt} \% \mathrm{~S}] \cdot \mathrm{f}_{\mathrm{S}}(1 \mathrm{wt} \%)}$

$\mathrm{K}_{2}=\frac{(\mathrm{wt} \% \mathrm{~S}) \mathrm{C} \gamma_{\mathrm{S}^{2-}}}{\mathrm{a}_{\mathrm{O}^{2-}}} \cdot\left(\frac{\mathrm{P}_{\mathrm{O}^{2}}}{\mathrm{P}_{\mathrm{S}^{2}}}\right)^{\frac{1}{2}}$

A new reaction can be constructed by combining Reactions $2-10$ and 2-11 as follow:

$\frac{1}{2} \mathrm{~S}_{2}(\mathrm{~g})+[\mathrm{O}]=\frac{1}{2} \mathrm{O}_{2}(\mathrm{~g})+[\mathrm{S}]$

The equilibrium constant for reaction 2-22 can be expressed as follows:

$K=\frac{[w t \% S] \cdot f_{s}(1 w t \%)}{h_{O}(1 w t \%)} \cdot\left(\frac{P_{\mathrm{O}_{2}}}{P_{S_{2}}}\right)^{\frac{1}{2}}$ 
The sulphur capacity and the sulphur partition ratio can then be obtained by rearranging Equations 2-20 and 2-21:

$\frac{(w t \% S)}{[w t \% S]}=\frac{K_{1} a_{O^{2-}} \cdot f_{S}(1 w t \%)}{C \gamma_{S^{2-}} \cdot h_{O}(1 w t \%)}=L_{S}$

Where: $\mathrm{L}_{\mathrm{S}}$ is sulphur partition ratio.

Fincham and Richardson [46] defined the sulphide capacity, $\mathrm{C}_{\mathrm{S}}$, of the slag as follows:

$$
\begin{aligned}
& (w t \% s)_{\text {slag }}=\frac{\mathrm{K}_{2} \mathrm{a}_{\mathrm{O}^{2-}}}{\mathrm{C} \gamma_{\mathrm{S}^{2-}}} \cdot \sqrt{\frac{\mathrm{P}_{\mathrm{S}_{\mathrm{S}}}}{\mathrm{P}_{\mathrm{O}_{2}}}} \\
& \mathrm{C}_{\mathrm{S}}=\frac{\mathrm{K}_{2} \mathrm{a}_{\mathrm{O}^{2-}}}{\mathrm{C} \gamma_{\mathrm{S}^{2-}}}=(\mathrm{wt} \% \mathrm{~S})_{\text {slag }} \cdot\left(\frac{\mathrm{P}_{\mathrm{O}_{2}}}{\mathrm{P}_{\mathrm{S}_{2}}}\right)^{\frac{1}{2}}
\end{aligned}
$$

Where $(\mathrm{wt} \% \mathrm{~S})$ is the concentration of sulphur in the slag, while $\mathrm{P}_{\mathrm{O} 2}$ and $\mathrm{P}_{\mathrm{S} 2}$ are partial pressures of oxygen and sulphur in the gas phase from the slag-gas exchange reaction [46].

The value of $\mathrm{C}_{\mathrm{S}}$ the sulphide capacity of the slag is a directly measurable quantity that can be used as a property which depends on temperature and composition of slag. This is a valuable parameter to compare the desulphurization ability of different slags.

The relationship between sulphur partition ratio $\left(\mathrm{L}_{S}\right)$ and sulphide capacity $\left(\mathrm{C}_{S}\right)$ can be obtained by combining Equations 2-23 and 2-26:

$\mathrm{C}_{\mathrm{s}}=(\mathrm{wt} \% \mathrm{~S}) \cdot \frac{\mathrm{K} \cdot \mathrm{h}_{\mathrm{O}}(1 \mathrm{wt} \%)}{[\mathrm{wt} \% \mathrm{~S}] \cdot \mathrm{f}_{\mathrm{s}}(1 \mathrm{wt} \%)}$

$\log _{C_{S}}=\log (w t \% S)+\log K+\log h_{O}(1 w t \%)-\log [w t \% s]-\log f_{s}(1 w t \%)$

$\log C_{s}=\log \frac{(w t \% S)}{[w t \% S]}+\log K-\log f_{s}(1 w t \%)+\log h_{O}(1 w t \%)$

The equilibrium constant $\mathrm{K}$ can be derived from the standard free energy.

The standard free energy and equilibrium constant for reaction 2-22 are: 
$\log \mathrm{K}=\frac{935.45}{\mathrm{~T}}-1.375$

By substituting $\log \mathrm{K}$ as $\left(\frac{935.45}{\mathrm{~T}}-1.375\right)$ and $\frac{(\mathrm{wt} \% \mathrm{~S})}{[\mathrm{wt} \% \mathrm{~S}]}$ as $\left(\mathrm{L}_{\mathrm{S}}\right)$, Equation $\mathbf{2 - 2 9}$ can be re-written as:

$\log C_{s}=\log L_{s}+\log h_{0}(1 w t \%)-\log f_{s}(1 w t \%)+\frac{935.45}{T}-1.375$

Considering the dissolution of oxygen into liquid iron, the equation is:

$\frac{1}{2} \mathrm{O}_{2}(\mathrm{~g})=[\mathrm{O}] \quad \Delta \mathrm{G}^{\circ}=-115750-4.63 \mathrm{~T} \quad \mathrm{~J} \cdot \mathrm{mol}^{-1}$

$\mathrm{K}=\frac{\mathrm{h}_{\mathrm{O}}(1 w \mathrm{t} \%)}{\mathrm{P}_{\mathrm{O}_{2}}^{\frac{1}{2}}}$

$\log \mathrm{K}=\log \mathrm{h}_{\mathrm{O}}(1 \mathrm{wt} \%)-\frac{1}{2} \ln \mathrm{P}_{\mathrm{O}_{2}}=\frac{6121}{\mathrm{~T}}+0.15$

$\log \mathrm{h}_{\mathrm{O}}(1 \mathrm{wt} \%)=\frac{1}{2} \ln \mathrm{P}_{\mathrm{O}_{2}}+\frac{6121}{\mathrm{~T}}+0.15$

By substituting $\log \mathrm{h}_{\mathrm{O}}(1 \mathrm{wt} \%)$ into Equation 2-32, the following equation can be presented:

$\log \mathrm{C}_{\mathrm{S}}=\log \mathrm{L}_{\mathrm{S}}+\frac{1}{2} \log \mathrm{P}_{\mathrm{O}_{2}}-\log \mathrm{f}_{\mathrm{S}}+\frac{7055}{\mathrm{~T}}-1.224$

where $f_{S}$, the activity coefficient for low solute content, can be obtained by using the following formulation:

$\log f_{i}=e_{i}^{i}[\% i]+\sum e_{i}^{j}[\% j]$ 
In this equation, i represents the dissolved element in the liquid metal and $e_{i}^{j}$ is the interaction coefficient of $i$ as affected by alloying element $j$.

The dependence of final sulphur content $[\mathrm{S}]_{f}$ and initial sulphur content $[\mathrm{S}]_{i}$ in liquid steel, the sulphur distribution ratio, $\mathrm{L}_{S}$, and the ratio of slag to metal quantities, $Q$, is given here:

$[\mathrm{S}]_{\mathrm{f}}=\frac{[\mathrm{S}]_{\mathrm{i}}}{1+\mathrm{L}_{\mathrm{S}} \cdot \mathrm{Q}}$

Equation 2-39 and Equation 2-37 are important for evaluation of the desulphurization in the steelmaking process.

\subsubsection{Composition and temperature dependence of sulphide capacity}

Many efforts have been made to determine the composition and temperature dependence of sulphide capacity [41, 47-50]. The basicity has traditionally been considered as being a function of composition. Nevertheless, it may vary with temperature due to thermally activated polymerization or depolymerization of the complex ions in the slag melt [41, 51].

\subsubsection{Relationship between optical basicity and sulphide capacity}

An empirical model was developed by Sommerville and Sosinsky [51] where sulphide capacity was related to the composition through optical basicity as shown in Figure 2-6. The resulting relationship that they obtained for a temperature of $1500^{\circ} \mathrm{C}$ is given as:

$\log \mathrm{C}_{\mathrm{S}}=12.6 \Lambda-12.3$

Sosinsky and Sommerville [41] also investigated temperature dependence of sulphide capacity based on previously measured data for melts free of transition metal oxides. Their results are shown in Figure 2-7. 


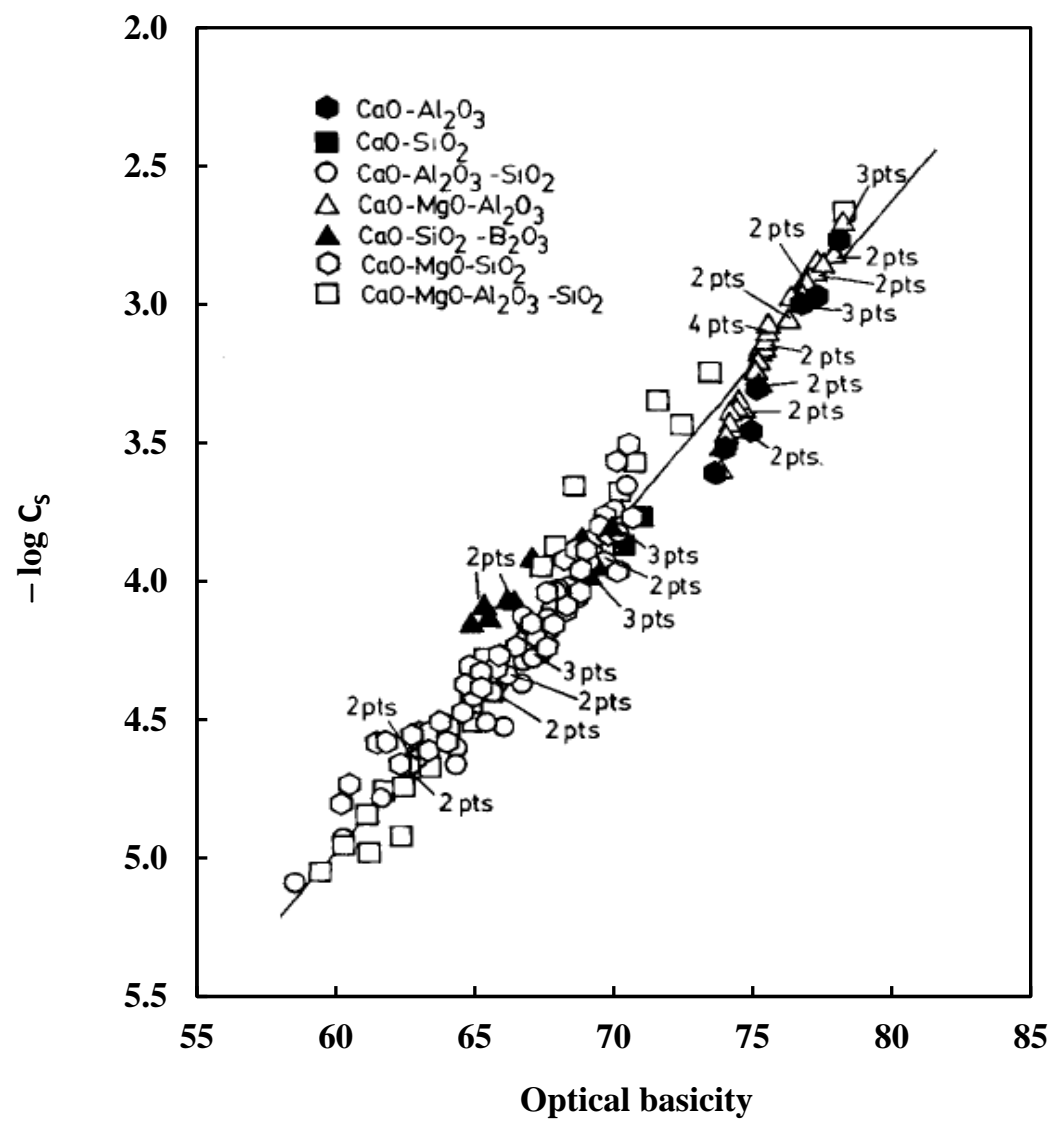

Figure 2-6: Relationship between sulphide capacity and optical basicity of slags at $1500{ }^{\circ} \mathrm{C}$ [41]

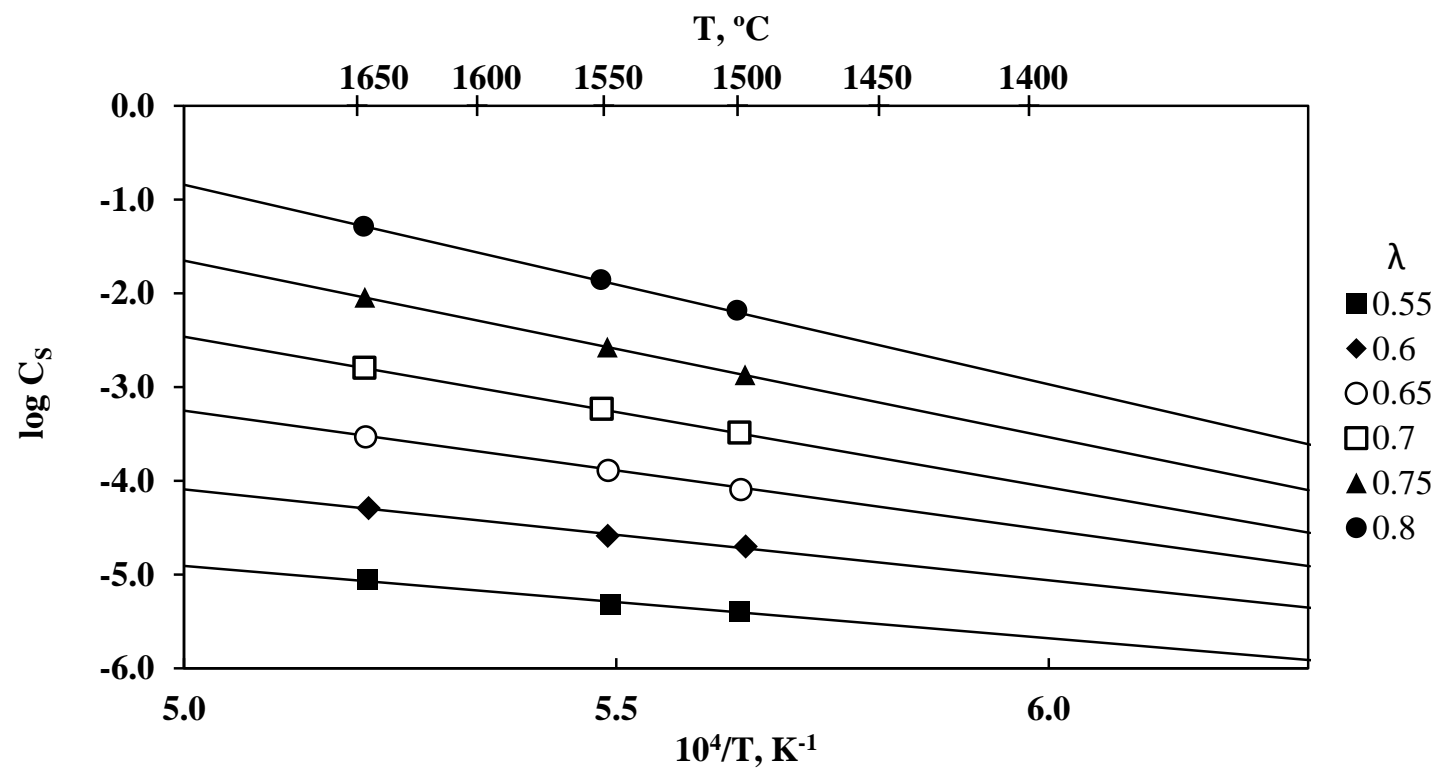

Figure 2-7: Plot of the logarithm of the sulphide capacity vs. 1/T for various iso-optical basicities [41] 
Taniguchi et al. [52] studied the relationship between $\log C_{S}$ and temperature. Their results are shown in Figure 2-8 along with other published data. It can be seen that the slope of $\log \mathrm{C}_{\mathrm{S}} \mathrm{vs.}$ $10^{4} / \mathrm{T}$ from Taniguchi et al. work [52] is in very good agreement with that of Hayakawa et al. [50]. The relationship is linear with slight increase of the slope at higher optical basicity.

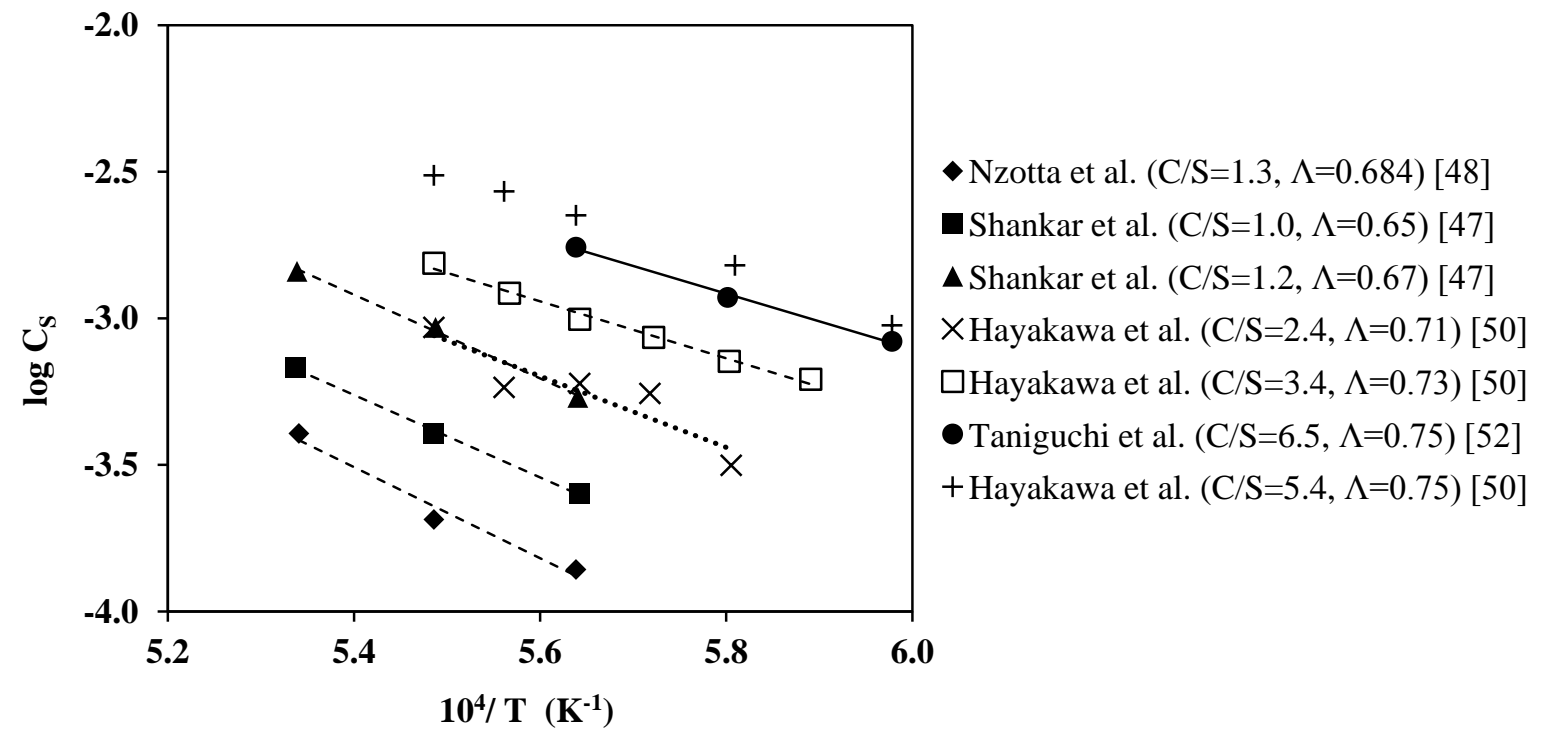

Figure 2-8: Relationship between $\log \mathrm{C}_{\mathrm{S}}$ and temperature in $\mathrm{CaO}-\mathrm{Al}_{2} \mathrm{O}_{3}-\mathrm{SiO}_{2}-\mathrm{MgO}$ slags, numerical values show optical basicity [52]

Equation 2-40 is useful only for a fixed temperature of $1500{ }^{\circ} \mathrm{C}$. Therefore, Sosinsky and Sommerville [41] derived an empirical correlation between sulphide capacity, optical basicity and temperature in the range $1400{ }^{\circ} \mathrm{C} \leq \mathrm{T} \leq 1700{ }^{\circ} \mathrm{C}$ which is appropriate for ironmaking, external treatment of hot metal and steelmaking. The relation is shown by the following equation:

$\log C_{S}=\frac{22690-54640 \Lambda}{T}+43.6 \Lambda-25.2$

where: $\mathrm{T}$ is the temperature in $\mathrm{K}$ and

$\Lambda$ is the optical basicity.

Young et al. [53] showed that Equation 2-41 can be applied for higher sulphide capacity. Therefore, Young et al. modified the Sosinsky's expression and suggested the following relationships: 
For $\Lambda \leq 0.8$

$$
\begin{gathered}
\log \mathrm{C}_{\mathrm{S}}=-13.913+42.84 \Lambda-23.82 \Lambda^{2}-\left(\frac{11710}{\mathrm{~T}}\right)-0.02223\left(\% \mathrm{SiO}_{2}\right) \\
-0.02275\left(\% \mathrm{Al}_{2} \mathrm{O}_{3}\right)
\end{gathered}
$$

For $\Lambda \geq 0.8$

$$
\begin{aligned}
& \log C_{S}=- 0.6261+0.4808 \Lambda+0.7917 \Lambda^{2}-\left(\frac{1697}{T}\right)+\frac{2587 \Lambda}{T}-5.144 \\
& \times 10^{-4}(\% \mathrm{FeO})
\end{aligned}
$$

\subsubsection{Sulphide capacity measurement techniques}

According to different literature [32, 47, 48,54] two types of experiments can be performed to obtain the sulphide capacity of a slag under equilibrium conditions. The first technique [32, 54] involves equilibrating slag and metal in a controlled atmosphere. Then sulphide capacity can be calculated from the sulphur distribution ratio, temperature, and the oxygen potential of the system according to Equation 2-37. In the second method [47, 48] the sulphide capacity is defined from the slag-gas equilibrium reaction with a gas mixture of known oxygen and sulphur partial pressures to describe the absorption potential of sulphur from the gas phase to form sulphide in the slag phase.

\subsubsection{Slags in desulphurization}

External desulphurization is a common practice in hot metal pretreatment. The desulphurization of hot metal is often achieved using fluxes based on either sodium carbonate or lime.

\subsubsection{Sodium carbonate based fluxes}

Sodium carbonate or soda ash is a common desulphurization agent in the steelmaking process. Upon injection into liquid iron, sodium carbonate decomposes to $\mathrm{Na}_{2} \mathrm{O}$ and $\mathrm{CO}_{2}$. Silicon in the melt is oxidized by $\mathrm{CO}_{2}$ and together with $\mathrm{Na}_{2} \mathrm{O}$ forms a $\mathrm{Na}_{2} \mathrm{O}-\mathrm{SiO}_{2}$ slag.

The thermodynamics of sulphur in binary $\mathrm{Na}_{2} \mathrm{O}-\mathrm{SiO}_{2}$ slags has been measured by Nagashima and Katsura [55] using slag-gas techniques under various oxygen partial pressures at $1100{ }^{\circ} \mathrm{C}$, $1250{ }^{\circ} \mathrm{C}$, and $1300{ }^{\circ} \mathrm{C}$. The results of their study indicate that the solubility of sulphur in slag 
reaches a minimum at a specific oxygen partial pressure while the temperature, $\mathrm{Na}_{2} \mathrm{O} / \mathrm{SiO}_{2}$ ratio, and the total amount of sulphur in the gas phase are constant.

They also found that the dissolved sulphur in the melts generally appears as sulphate ions at high oxygen partial pressure $\left(P_{O_{2}}>10^{-10}\right.$ atm), whereas the sulphur dissolved commonly as sulphide ions at lower oxygen partial pressure [55].

Chan and Fruehan [56] studied the sulphur partition ratios and sulphide capacity between carbon saturated iron and $\mathrm{Na}_{2} \mathrm{O}-\mathrm{SiO}_{2}$. Their study was undertaken using both the slag-metal and the gasslag techniques for sulphur partition ratio and sulphide capacity respectively. The results of the two measurements are shown in Figure 2-9. They also found these slags with high sulphide capacity could absorb $5 \mathrm{wt} \% \mathrm{~S}$ at 0.4 mole fraction $\mathrm{Na}_{2} \mathrm{O}$.

Inoue and Suito [54] carried out similar experiments on the sulphur partition ratio between carbon saturated iron and $\mathrm{Na}_{2} \mathrm{O}-\mathrm{SiO}_{2}$ slags at $1250{ }^{\circ} \mathrm{C}$ and $1350{ }^{\circ} \mathrm{C}$. The results of Chan and Fruehan's [56] investigation are shown in Figure 2-10 along with Inoue and Suito's [54] data.

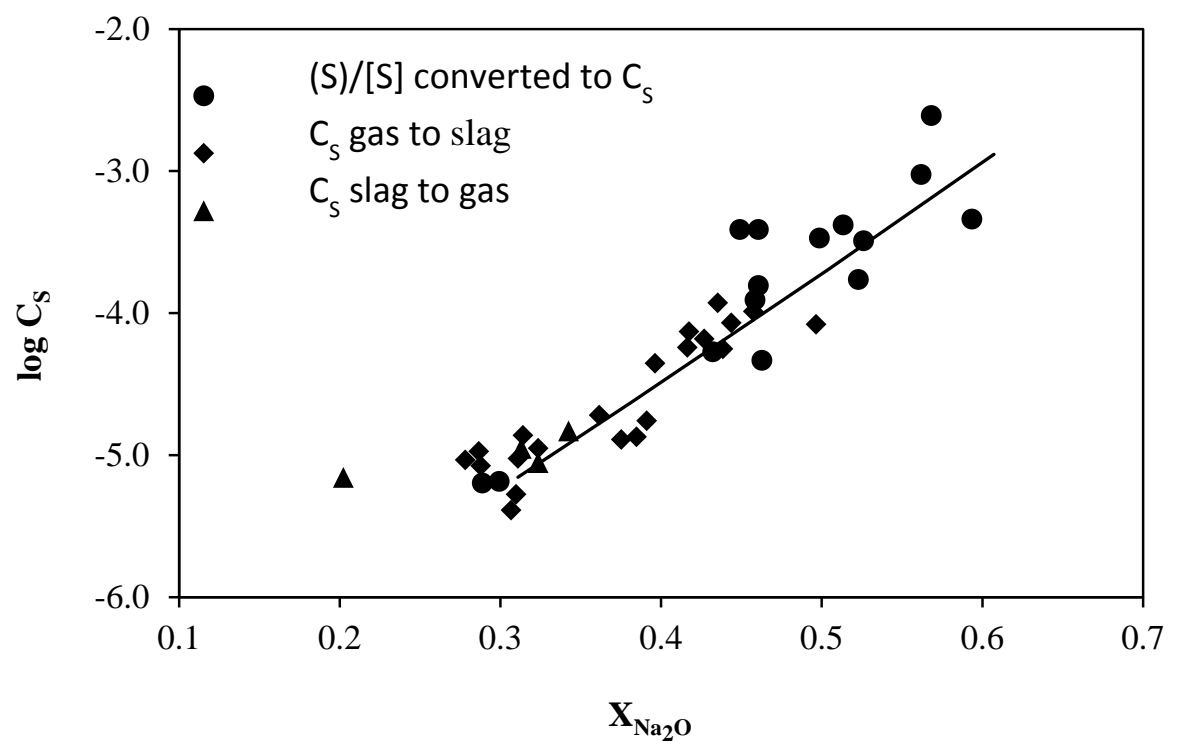

Figure 2-9: Correlation between $\mathrm{Na}_{2} \mathrm{O}$ mole fraction and sulphide capacities at $1200{ }^{\circ} \mathrm{C}$ as measured by the gas-slag method and partition ratio data from slag-metal converted to sulphide capacity via the $\mathrm{C}-\mathrm{CO}$ equilibrium with $\mathrm{P}_{\mathrm{CO}}=1 \mathrm{~atm}$ 


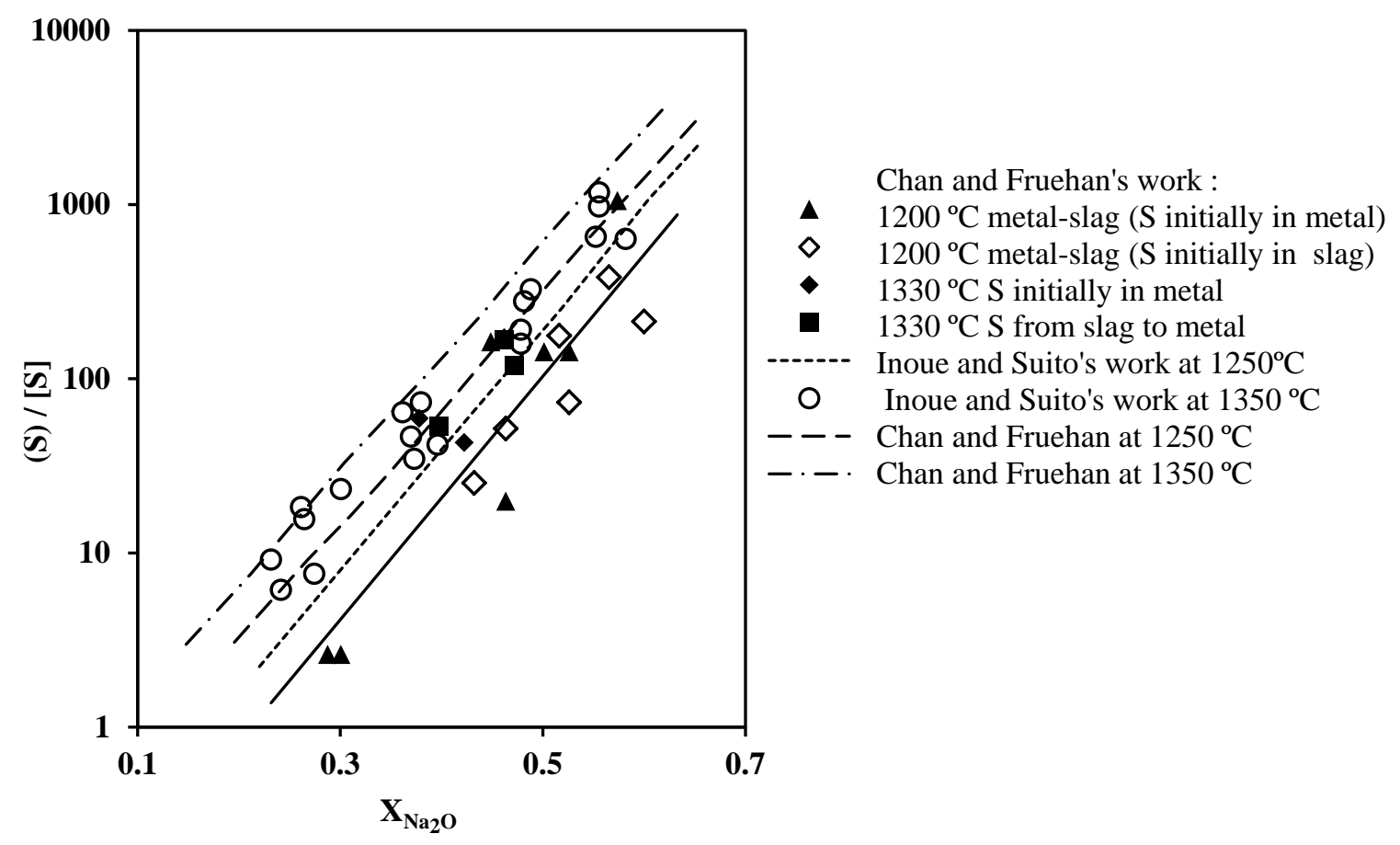

Figure 2-10: Measured sulphur partition ratio data from Chan and Fruehan [56] and Inoue and Suito [54]

Kunisada and Iwai [57] investigated the effect of $\mathrm{CaO}, \mathrm{MnO}, \mathrm{MgO}$ and $\mathrm{Al}_{2} \mathrm{O}_{3}$ on the sulphide capacity of $\mathrm{Na}_{2} \mathrm{O}-\mathrm{SiO}_{2}$ slags at $1500{ }^{\circ} \mathrm{C}$ using a slag-gas equilibrium technique in a platinum crucible. They showed that for these binary slags, the sulphide capacity can be related to the basicity as follows:

$\log \mathrm{C}_{\mathrm{S}}=4.64 \mathrm{~B}-6.88 \quad\left(1500^{\circ} \mathrm{C}\right)$

$\mathrm{B}=\frac{\mathrm{Na}_{2} \mathrm{O}}{\mathrm{SiO}_{2}} \quad$ [mole ratio]

In addition, they found that the sulphide capacity of the $\mathrm{Na}_{2} \mathrm{O}-\mathrm{SiO}_{2}$ slags increases with adding basic oxides such as $\mathrm{CaO}, \mathrm{MnO}$ and $\mathrm{MgO}$ and decreases with $\mathrm{Al}_{2} \mathrm{O}_{3}$ addition as shown in Figure 2-11. 


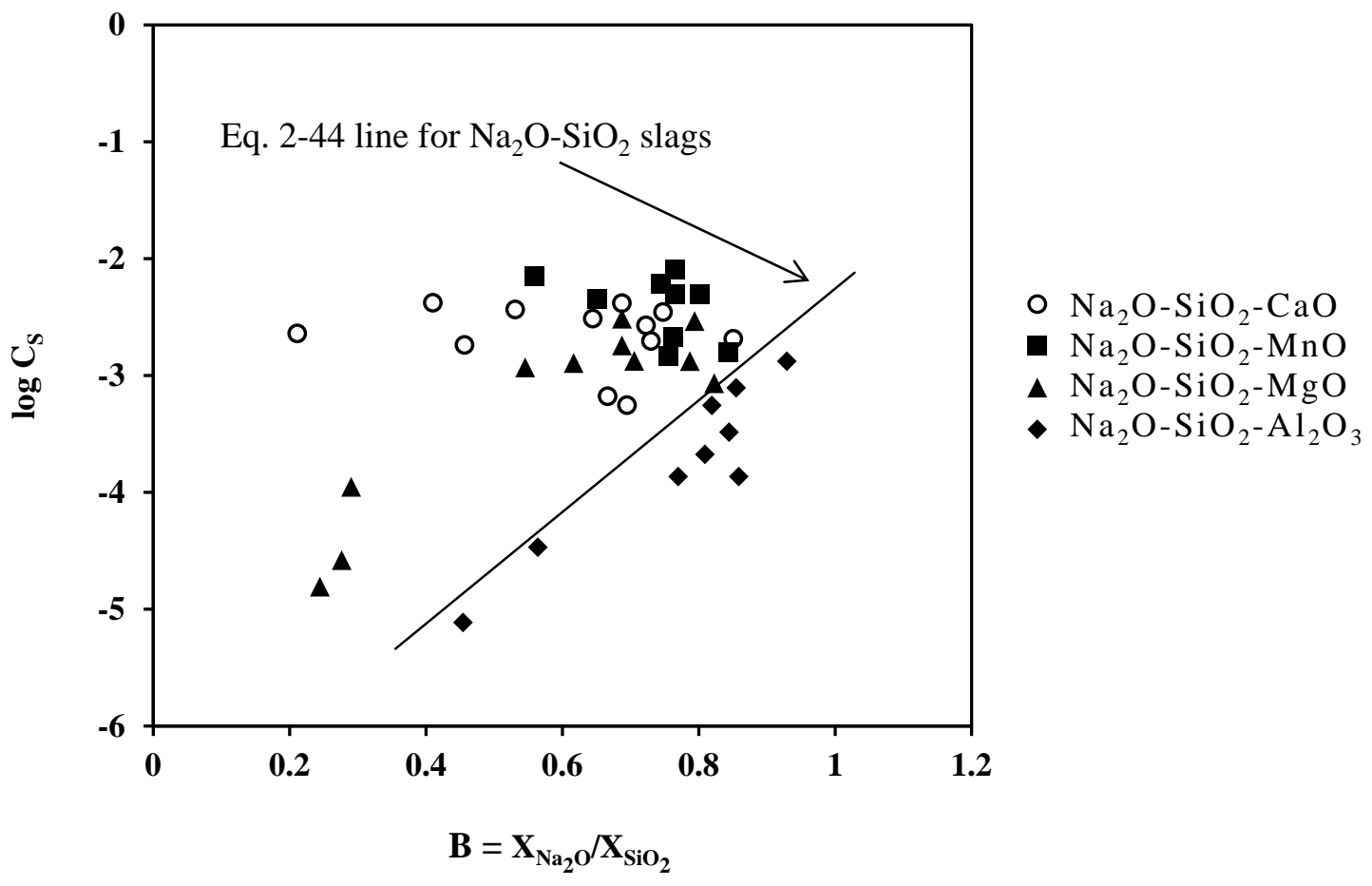

Figure 2-11: Effect of $\mathrm{CaO}, \mathrm{MnO}, \mathrm{MgO}$ and $\mathrm{Al}_{2} \mathrm{O}_{3}$ on the sulphide capacity of $\mathrm{Na}_{2} \mathrm{O}-\mathrm{SiO}_{2}$ slags [57]

\subsubsection{Calcium oxide based fluxes}

The desulphurization of hot metal by calcium oxide (lime) based fluxes is an efficient and inexpensive method for hot metal treatment.

These slags contain other oxides such as $\mathrm{Al}_{2} \mathrm{O}_{3}, \mathrm{SiO}_{2}, \mathrm{MnO}, \mathrm{MgO}$ and $\mathrm{FeO}$. In a multicomponent slag system, the $\mathrm{MgO}$ and $\mathrm{CaO}$ are considered as basic oxides, whereas the $\mathrm{SiO}_{2}$ and $\mathrm{Al}_{2} \mathrm{O}_{3}$ are known as acidic components. Also, the oxygen potential of the system has a large effect on the sulphide capacity which can be dictated by the $\mathrm{FeO}$ and $\mathrm{MnO}$ contents of the flux. One further component found in most of these $\mathrm{CaO}$ based slags is calcium fluoride, $\mathrm{CaF}_{2}$, which primarily decreases the melting point of the slag.

The significant properties of $\mathrm{CaO}$ based slags and sulphur removal can be illustrated by the following equation:

$\mathrm{CaO}+\mathrm{S}=\mathrm{CaS}+\mathrm{O}$ 
This reaction shows lime in the slag phase reacts with sulphur in the metal phase to form calcium sulphide in the slag and oxygen in the metal. Clearly, desulphurization of the metal will be favored by slag containing high concentrations of lime and low oxygen content in the metal.

The sulphide capacities of lime based slags such as $\mathrm{CaO}-\mathrm{SiO}_{2}$ and $\mathrm{CaO}-\mathrm{Al}_{2} \mathrm{O}_{3}$ systems have been extensively investigated by others as presented in Table 2-9 and Figure 2-12. Based on the results in Figure 2-12, the sulphide capacities of $\mathrm{CaO}-\mathrm{SiO}_{2}$ slags are lower than the $\mathrm{CaO}-\mathrm{Al}_{2} \mathrm{O}_{3}$ slags, although the data obtained by different researchers do not completely agree with each other due to the fact that sulphur is not only present in slag as sulphide ions [58].

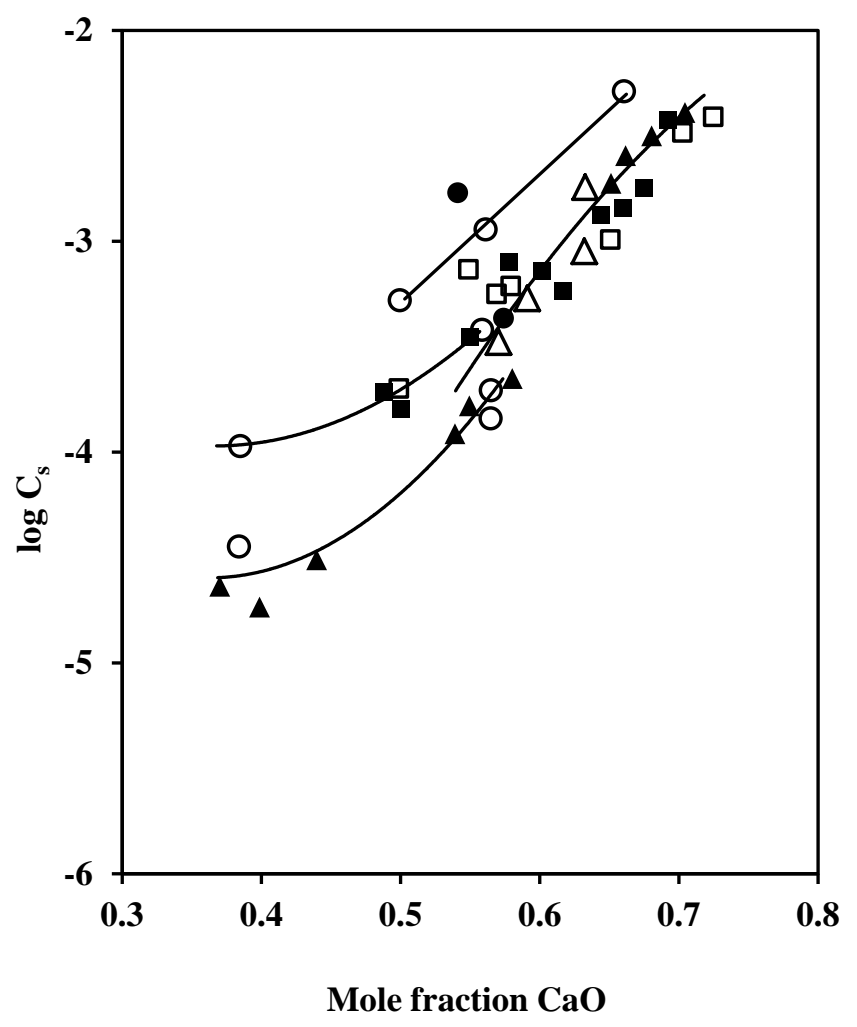

O Fincham and Richardson $\left(\mathrm{CaO}-\mathrm{Al}_{2} \mathrm{O}_{3}, 1650^{\circ} \mathrm{C}\right)$

- Fincham and Richardson $\left(\mathrm{CaO}-\mathrm{Al}_{2} \mathrm{O}_{3}-\mathrm{SiO}_{2} 1650^{\circ} \mathrm{C}\right)$

$\square$ Cameron et. al. $\left(\mathrm{CaO}-\mathrm{Al}_{2} \mathrm{O}_{3}, 1650^{\circ} \mathrm{C}\right)$

- Cameron et. al. $\left(\mathrm{CaO}-\mathrm{Al}_{2} \mathrm{O}_{3}-\mathrm{SiO}_{2}<10 \%, 1650{ }^{\circ} \mathrm{C}\right)$

$\Delta$ Carter and Mcfarlane $\left(\mathrm{CaO}-\mathrm{SiO}_{2}, 1500^{\circ} \mathrm{C}\right)$

$\Delta$ Sharma and Richardson $\left(\mathrm{CaO}-\mathrm{Al}_{2} \mathrm{O}_{3}, 1500{ }^{\circ} \mathrm{C}\right)$

Figure 2-12: Sulphide capacity of $\mathrm{CaO}$ based slags [59] 
Table 2-9: Sulphide capacity measurement in $\mathrm{CaO}$ based slags

\begin{tabular}{|c|c|c|l|}
\hline System & $\begin{array}{c}\text { Temperature, } \\
{ }^{\circ} \mathrm{C}\end{array}$ & $\begin{array}{c}\text { Experimental } \\
\text { method }\end{array}$ & \multicolumn{1}{c|}{ Ref. } \\
\hline $\mathrm{CaO}-\mathrm{SiO}_{2}$ & $1500-1600$ & Slag-gas & Fincham and Richardson [46] \\
\hline $\mathrm{CaO}-\mathrm{SiO}_{2}$ & 1500 & Slag-gas & Carter and Mcfarlane [60] \\
\hline $\mathrm{CaO}-\mathrm{Al}_{2} \mathrm{O}_{3}$ & 1500 & Slag-gas & Carter and Mcfarlane [60] \\
\hline $\mathrm{CaO}-\mathrm{Al}_{2} \mathrm{O}_{3}$ & 1500 & Slag-gas & Sharma and Richardson [61] \\
\hline $\mathrm{CaO}-\mathrm{Al}_{2} \mathrm{O}_{3}$ & 1500 & Slag-gas & Kor and Richardson [62] \\
\hline $\mathrm{CaO}-\mathrm{Al}_{2} \mathrm{O}_{3}$ & 1650 & Slag-gas & Fincham and Richardson [46] \\
\hline $\mathrm{CaO}-\mathrm{Al}_{2} \mathrm{O}_{3}$ & 1650 & Slag-gas & Cameron, Gibbons and Tylor [63] \\
\hline $\mathrm{CaO}-\mathrm{Al}_{2} \mathrm{O}_{3}-\mathrm{SiO}_{2}(<10 \%)$ & 1500 & Slag-gas & Fincham and Richardson [46] \\
\hline $\mathrm{CaO}-\mathrm{Al}_{2} \mathrm{O}_{3}-\mathrm{SiO}_{2}(<10 \%)$ & 1550 & Slag-gas & Cameron, Gibbons and Tylor [63] \\
\hline $\mathrm{CaO}_{2}-\mathrm{CaCl}_{2}$ & $1175-1350$ & Slag -metal & Yang and McLean [64] \\
\hline $\mathrm{CaO}_{2} \mathrm{Na}_{2}{\mathrm{O}-\mathrm{SiO}_{2}}$ & 1400 & Slag-gas & Chan and Fruehan [59] \\
\hline
\end{tabular}

Yang et al. [64] calculated the sulphide capacity of $\mathrm{CaO}-\mathrm{CaCl}_{2}$ slags using phosphate capacity data at $1175{ }^{\circ} \mathrm{C}-1350{ }^{\circ} \mathrm{C}$ in a graphite crucible by the slag-metal technique. The plot of the sulphide capacity vs. optical basicity shows that slag sulphide capacity increases with optical basicity and temperature. The relationship between the sulphide capacity of $\mathrm{CaO}-\mathrm{CaCl}_{2}$ slags and optical basicity is shown in Figure 2-13.

The efficiency of lime based slags can be increased by the addition of $\mathrm{Na}_{2} \mathrm{O}$. Chan and Fruehan [59] investigated $\mathrm{CaO}-\mathrm{SiO}_{2}-\mathrm{Na}_{2} \mathrm{O}-\left(\mathrm{Al}_{2} \mathrm{O}_{3}\right)$ slags at $1400{ }^{\circ} \mathrm{C}$ and measured the sulphur partition ratio using the slag-metal method with carbon saturated iron melt and determined the sulphide capacity value by slag-gas techniques in graphite crucibles respectively. They concluded that the addition of 10 to $15 \mathrm{wt} \% \mathrm{Na}_{2} \mathrm{O}$ to $\mathrm{CaO}-\mathrm{SiO}_{2}$ slags increases the sulphide capacity and partition ratio by a factor of about 10 Figure $2-14$. However, adding $\mathrm{Na}_{2} \mathrm{O}$ at low 
concentration to $\mathrm{CaO}-\mathrm{Al}_{2} \mathrm{O}_{3}-\mathrm{SiO}_{2}$ slags did not have a significant effect on the sulphide capacity due to the high sulphide capacity of the slag without $\mathrm{Na}_{2} \mathrm{O}$ [59].

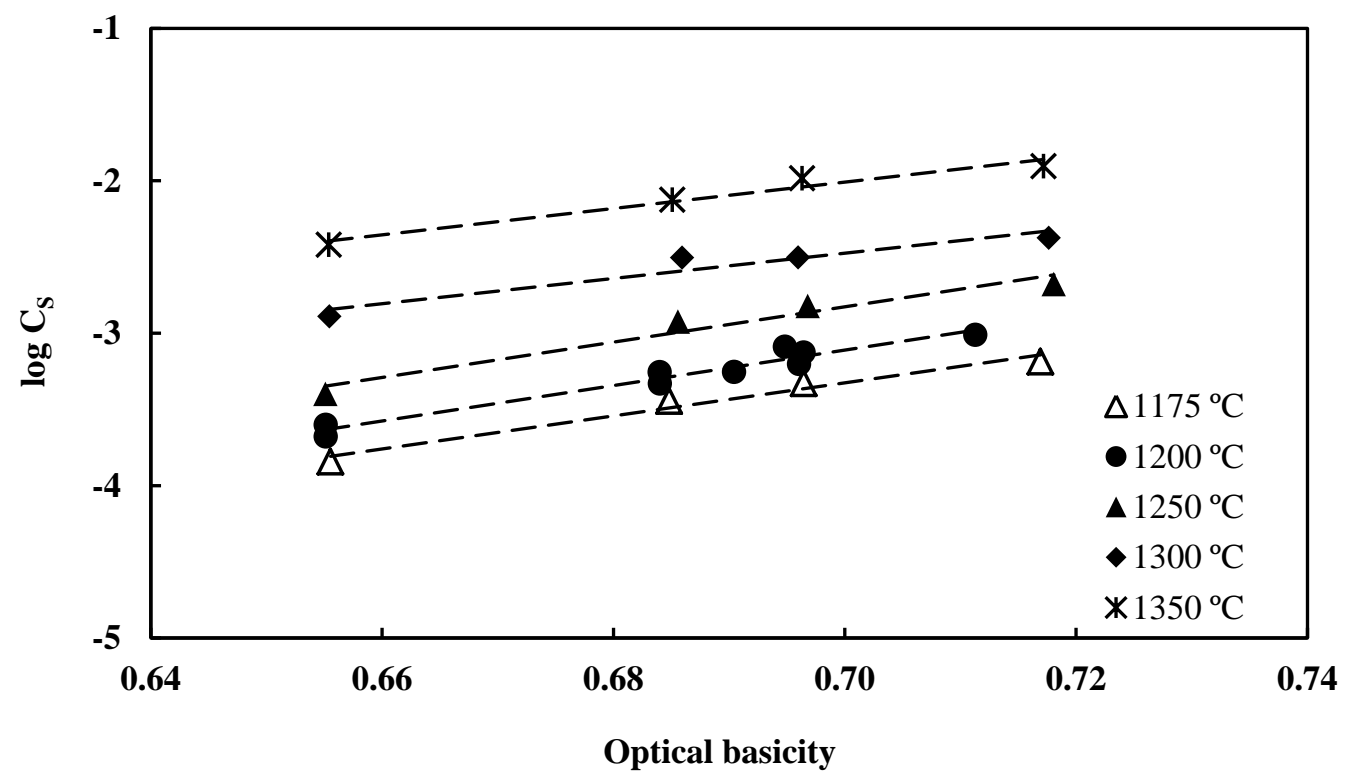

Figure 2-13: Relationship between sulphide capacity and optical basicity of $\mathrm{CaO}-\mathrm{CaCl}_{2}$ slags [64]

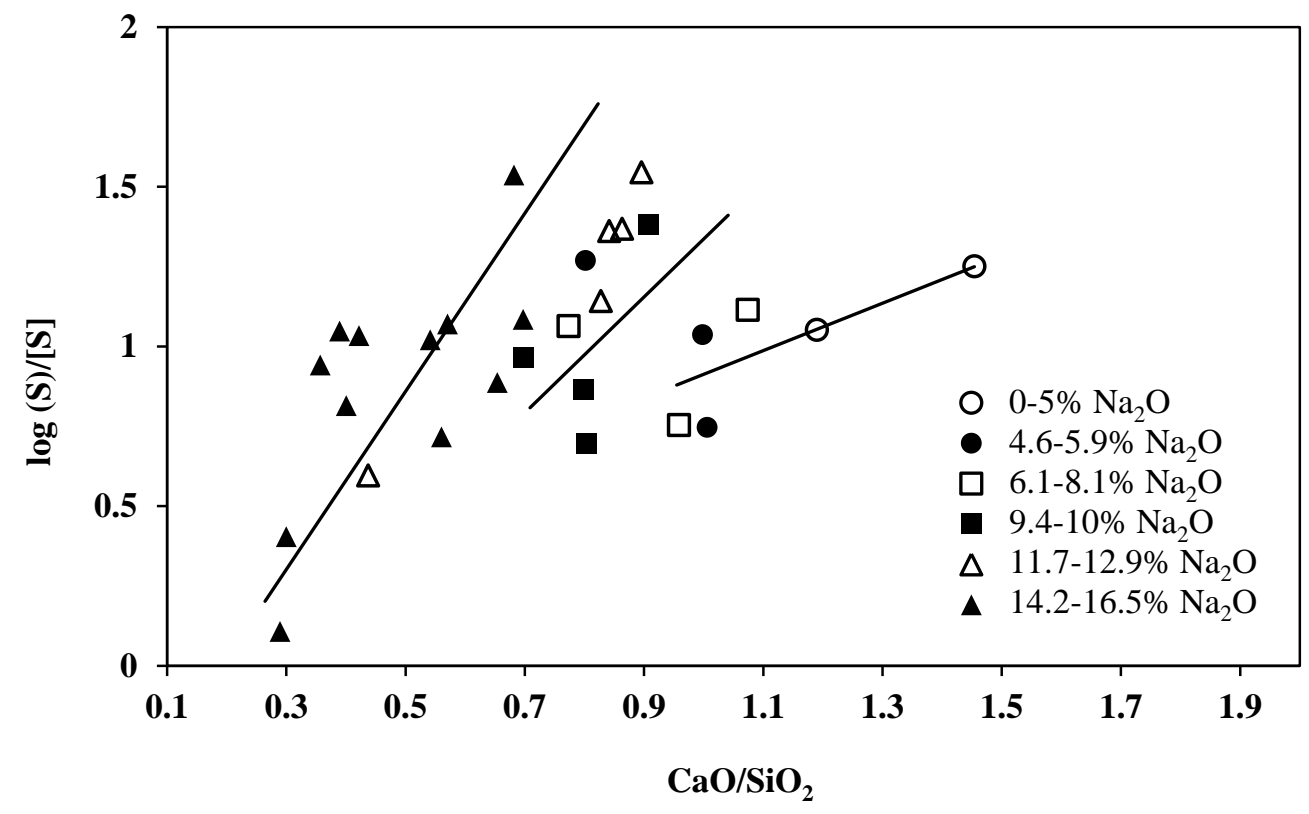

Figure 2-14: Sulphur partition ratio of $\mathrm{CaO}-\mathrm{Na}_{2} \mathrm{O}-\mathrm{SiO}_{2}$ slags at $1400{ }^{\circ} \mathrm{C}$ plotted at different $\mathrm{Na}_{2} \mathrm{O}$ levels [59] 


\subsection{Dephosphorization}

The hot metal dephosphorization process has been developed to meet increasing demands for low phosphorus steel and also treating high phosphorus ores. Dephosphorization success depends on basic and oxidizing slags, low temperature, and high fluidity of slag to achieve favorable thermodynamic and kinetic conditions. This review will concentrate on the literature related to hot metal treatment, rather than that concerning steelmaking.

\subsubsection{Thermodynamics of dephosphorization}

Phosphorus is introduced into liquid iron from the blast furnace raw materials such as iron ore, coke, and limestone, as well as from scrap during steelmaking. Phosphorus can be removed in a hot metal pretreatment process or during the steelmaking operation [31].

\subsubsection{Phosphate capacity}

Dephosphorization of hot metal is an important treatment during iron and steelmaking. Therefore, there has been a substantial interest in measuring the ability of fluxes and slags to remove phosphorus. The phosphorus distribution ratio (between slag and metal) and phosphate capacity of slags are important parameters to compare dephosphorization properties of different slags.

According to Wagner [65] and others, the equilibrium reaction for phosphorus distribution between liquid iron and slag can be written as:

$\frac{1}{2} \mathrm{P}_{2}(\mathrm{~g})+\frac{5}{4} \mathrm{O}_{2}(\mathrm{~g})+\frac{3}{2} \mathrm{O}^{2-}($ slag $)=\mathrm{PO}_{4}^{3-}($ slag $)$

Where the equilibrium constant is:

$$
\mathrm{K}=\frac{\mathrm{a}_{\mathrm{PO}_{4}^{-3}}}{\mathrm{P}_{\mathrm{P} 2}^{1 / 2} \cdot \mathrm{P}_{\mathrm{O} 2}^{5 / 4} \cdot \mathrm{a}_{\mathrm{O}^{-2}}^{\frac{3}{2}}}
$$

The phosphate capacity of the slag was suggested by Wagner [65] as follows:

$$
\mathrm{C}_{\mathrm{PO}_{4}^{3-}}=\frac{\left(\mathrm{wt} \% \mathrm{PO}_{4}^{3-}\right)_{\text {slag }}}{\mathrm{P}_{\mathrm{P} 2}^{1 / 2} \cdot \mathrm{P}_{\mathrm{O} 2}^{5 / 4}}=\mathrm{K}_{\mathrm{PO}_{4}^{3-}} \cdot \frac{\mathrm{a}_{\mathrm{O}^{2-}}^{3 / 2}}{\mathrm{f}_{\mathrm{PO}_{4}^{3-}}}
$$


Where:

wt pct $\mathrm{PO}_{4}^{3-}$ : Weight percent of $\mathrm{PO}_{4}^{3-}$ dissolved in slag

$f_{\mathrm{PO}_{4}^{3-}}:$ Activity coefficient at infinite dilution concentration

$P_{\mathrm{O}_{2}}$ : Oxygen partial pressure at the slag-metal interface

$P_{P_{2}}:$ Phosphorus partial pressure in equilibrium with the liquid metal

The phosphate capacity can be revised to expand its ease of application by considering as following [66]:

$\frac{1}{2} \mathrm{P}_{2}(\mathrm{~g})=[\mathrm{P}]_{(1 \mathrm{wt} \% \text { in } \mathrm{Fe})}$

$\Delta \mathrm{G}^{\circ}=-122352-19 \mathrm{~T}(\mathrm{~J})$

The equilibrium constant of this reaction is given by:

$\mathrm{K}=\frac{\mathrm{a}_{\mathrm{P}}}{\mathrm{P}_{\mathrm{P}_{2}}^{\frac{1}{2}}}$

The numerical value of $K$ can be expressed as follows:

$\log K=\frac{6392}{\mathrm{~T}}+0.99$

By substitution of Equations 2-52 and 2-53 into Equation 2-49, Equation 2-54 can be established in logarithmic form:

$$
\begin{aligned}
\log \mathrm{C}_{\mathrm{PO}_{4}^{3-}}= & \log (\mathrm{wt} \% \mathrm{P})_{(\text {slag })}+\log \left(\mathrm{MM}_{\mathrm{PO}_{4}^{3-}} / \mathrm{MM}_{\mathrm{P}}\right)-\log \mathrm{f}_{\mathrm{P}}[\mathrm{P}]_{(1 \mathrm{wt} \% \text { in Fe })}-\log \mathrm{P}_{\mathrm{O}_{2}}^{\frac{5}{4}} \\
+ & \frac{6392}{\mathrm{~T}}+0.99
\end{aligned}
$$

Where:

$f_{P}$ : The activity coefficient of phosphorus at $1 w t \%$ standard state in liquid iron.

$\mathrm{MM}_{\mathrm{PO}_{4}^{3-}} / \mathrm{MM}_{\mathrm{P}}$ : The ratio of the molar mass of phosphate and phosphorus in slag and metal, respectively, which is equal to 3.06. 
The phosphorus distribution ratio between the slag and metal at equilibrium, $\mathrm{L}_{\mathrm{P}}$, can be experimentally determined, and is defined as:

$\mathrm{L}_{\mathrm{P}}=\frac{(\mathrm{wt} \% \mathrm{P})}{[\mathrm{wt} \% \mathrm{P}]}$

Thus, the relationship between phosphate capacity and the phosphorus distribution ratio can be written as:

$$
\log \mathrm{L}_{\mathrm{P}}=\log \mathrm{C}_{\mathrm{PO}_{4}^{3-}}+\log \mathrm{f}_{\mathrm{P}}+\log \mathrm{P}_{\mathrm{O}_{2}}^{\frac{5}{4}}-\frac{6392}{\mathrm{~T}}-1.475
$$

For carbon saturated iron, partial pressure of oxygen in equilibrium with carbon is obtained via:

$$
\begin{aligned}
& \mathrm{C}(\mathrm{gr})+\frac{1}{2} \mathrm{O}_{2}(\mathrm{~g})=\mathrm{CO}(\mathrm{g}) \quad \Delta \mathrm{G}^{\circ}=-114391-85.77 \mathrm{~T}(\mathrm{~J} / \mathrm{mol}) \\
& \frac{1}{2} \log \mathrm{PO}_{2}=\operatorname{loga}_{\mathrm{C}}+\log \mathrm{P}_{\mathrm{CO}}-\left(\frac{5976}{\mathrm{~T}}+4.48\right)
\end{aligned}
$$

and the activity coefficient $f_{P}$ can be expressed as follows [67]:

$\log f_{P}=e_{P}^{C} \cdot w t \% C+e_{P}^{P} \cdot w t \% P$

By replacement of $e_{P}^{C}=0.145, e_{P}^{P}=0.062$ [68] the following relationship is obtained at $1350^{\circ} \mathrm{C}$ :

$\log f_{P}=0.145 \cdot$ wt $\% C+0.062 \cdot$ wt $\% \mathrm{P}$

\subsubsection{Relationship between phosphate capacity and optical basicity}

Although the phosphate capacity $\left(\mathrm{C}_{\mathrm{PO}_{4}^{3-}}\right)$ is usually defined by Equation 2-54, various other expressions have been defined to show a relationship between optical basicity and phosphate capacity. Gaskell [69] analyzed phosphorus distribution from data by Suito et al. [70] and established a relationship between the dephosphorization equilibrium, optical basicity, and temperature as follows :

$$
\ln \left(\frac{\mathrm{X}_{\mathrm{PO}_{4}^{3-}}}{[\% \mathrm{P}][\%]^{2.5}}\right)=\left(-558.874+\frac{2.176 \times 10^{6}}{\mathrm{~T}}-1.93 \times \frac{10^{9}}{\mathrm{~T}^{2}}\right) \Lambda-28.78
$$


Mori [71] studied the dephosphorization equilibrium by use of optical basicity and showed that a linear relationship between $\log \mathrm{C}_{\mathrm{P}}$ and optical basicity exists at $1600{ }^{\circ} \mathrm{C}$ :

$\log \mathrm{C}_{\mathrm{PO}_{4}^{3-}}=17.55 \Lambda+5.72$

Mori’s experimental results are shown in Figure 2-15 for different slag systems.

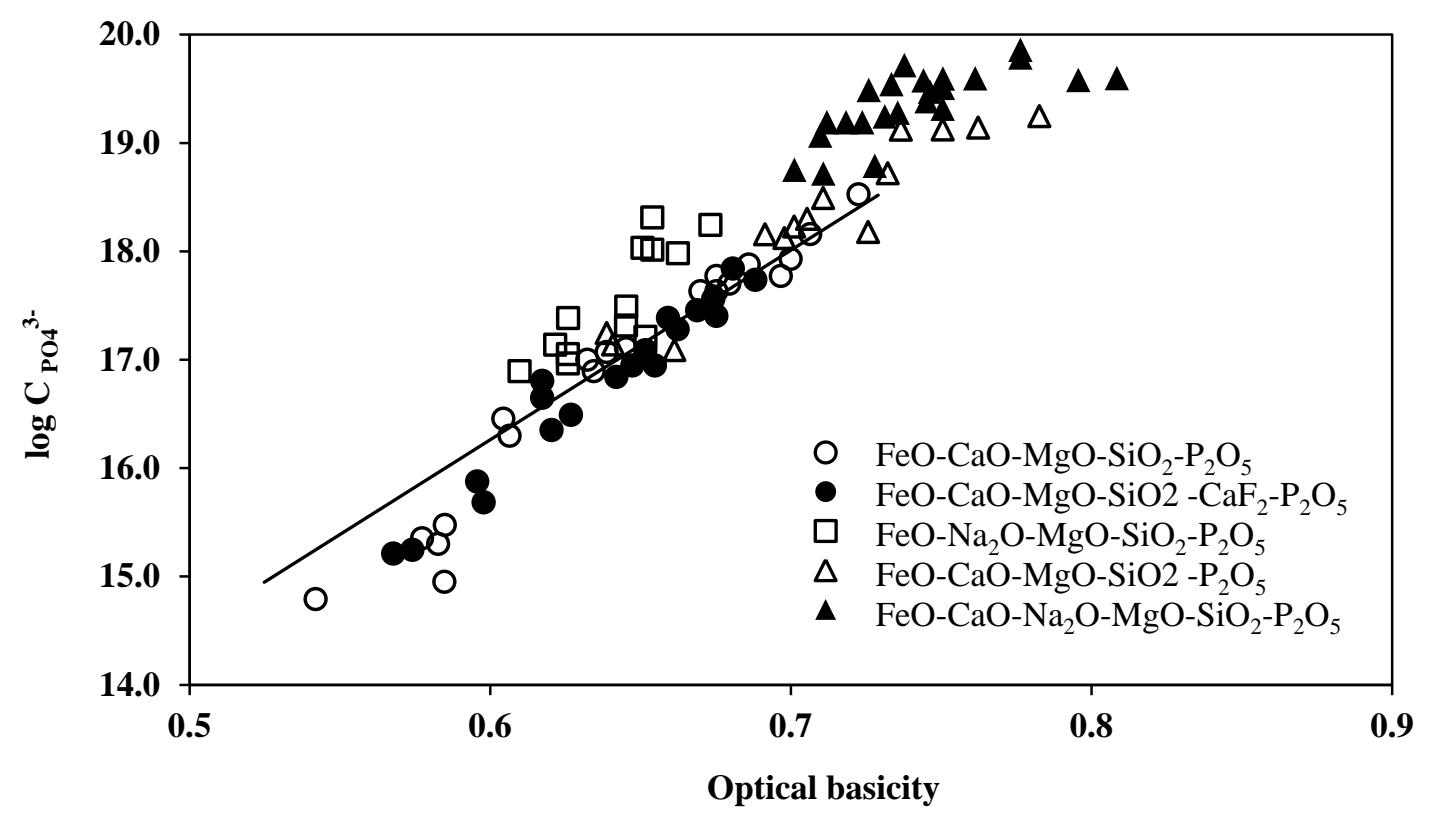

Figure 2-15: Relationship between $\log \mathrm{C}_{\mathrm{PO} 4}{ }^{3-}$ and optical basicity [71]

Bergman [72] also analyzed Suito et al.'s [70] experimental data in terms of phosphate monomer $\left(\mathrm{PO}_{4}^{3-}\right)$ and dimer $\left(\mathrm{P}_{2} \mathrm{O}_{7}^{4-}\right)$ and showed $\log \mathrm{C}_{\mathrm{PM}}^{(3)}$ for phosphate monomer correlated linearly with the optical basicity as follows:

$\log C_{P M}^{(3)}=21.30 \Lambda+\frac{32912}{T}-27.90$

Yang et al. [44] studied slag-metal equilibrium with different lime based slags under CO gas atmosphere in a graphite crucible at various temperatures. Their results in Figure 2-16 show the linear relationship between optical basicity and the phosphate capacity of a number of slags. It can be seen that for all slags, phosphate capacity increases with increasing optical basicity. 


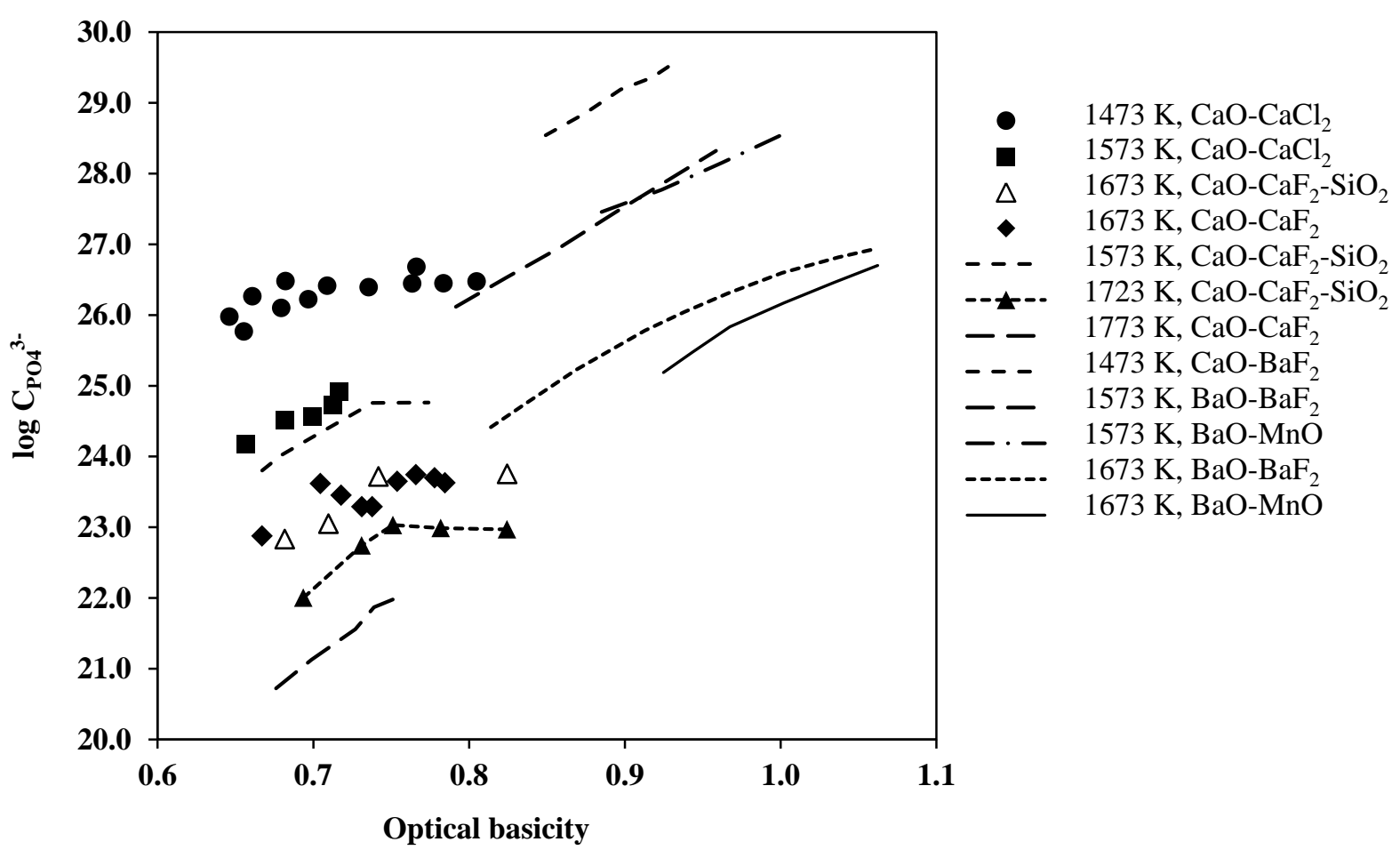

Figure 2-16: Comparison of the phosphate capacity of slags from different studies [44]

In the slags saturated with $\mathrm{CaO}$, further addition of $\mathrm{CaO}$ does not change the basicity of the liquid phase of the slag, whereas the apparent value of the optical basicity increases with $\mathrm{CaO}$ addition, hence the constant value after a certain optical basicity for these slags. It can further be seen that the phosphate capacity of slags decreases with an increase in temperature. The authors suggested the data in Figure 2-16 can be represented by a regression equation as follows:

$\log \mathrm{C}_{\mathrm{PO}_{4}^{3-}}=\left(-\frac{36412}{\mathrm{~T}}+37\right) \Lambda+\frac{71493}{\mathrm{~T}}-30.08$

\subsubsection{Hot metal dephosphorization fluxes}

The dephosphorization fluxes often contain alkali metal oxide and carbonates, most commonly sodium carbonate, and the alkaline earth metal oxides, commonly calcium oxide [73, 74]. 


\subsubsection{Sodium carbonate based slags}

Sodium carbonate is one of the most effective additives to dephosphorization fluxes. Pak and Fruehan [75] reported that the earliest work with a sodium carbonate system as a dephosphorizer was done by Eaton in 1877 who performed dephosphorization of hot metal prior to decarburizing it in a converter. Afterward, Maddocks and Turkdogan [74, 76] and Oelsen [77] investigated the use of a sodium carbonate based flux for dephosphorization of hot metal. Their results show that although the slag and metal did not reach equilibrium, very high degrees of dephosphorization were achieved.

It should be noted that, upon injection of carbonate reagents into the hot metal, $\mathrm{Na}_{2} \mathrm{CO}_{3}$ decomposes into $\mathrm{Na}_{2} \mathrm{O}$ and $\mathrm{CO}_{2}$. The $\mathrm{Na}_{2} \mathrm{O}$ can react with other oxides, such as $\mathrm{SiO}_{2}$, to form a $\mathrm{Na}_{2} \mathrm{O}-\mathrm{SiO}_{2}$ slag. Various studies have been done to investigate the phosphate capacity and phosphorus distribution ratio of $\mathrm{Na}_{2} \mathrm{O}-\mathrm{SiO}_{2}$ slags.

Inoue and Suito [78-80] and their coworkers investigated the dephosphorization of carbon saturated iron using sodium carbonate and/or sodium sulphate fluxes in the temperature range of $1250{ }^{\circ} \mathrm{C}$ to $1350{ }^{\circ} \mathrm{C}$. They studied the time dependent behavior of phosphorus, sulphur, and manganese in carbon saturated iron after the addition of sodium based fluxes [80]. In addition they investigated the phosphorus distribution ratio between carbon saturated iron and sodium based fluxes in a graphite crucible under a $\mathrm{CO}$ gas flow [78]. Also, they studied the reaction of sodium based fluxes with iron, carbon, and phosphorus dissolved in iron by the use of iron, graphite, and magnesia crucibles [79].

Niekerk and Dippenaar [67] studied the phosphorus distribution between carbon saturated iron and slags containing $\mathrm{Na}_{2} \mathrm{O}$ and $\mathrm{SiO}_{2}$ at $1350^{\circ} \mathrm{C}$ in a graphite crucible under $\mathrm{CO}$ gas atmosphere. The phosphate capacity was calculated by assuming $\mathrm{P}_{\mathrm{CO}}=1$ atm and considering the activity of carbon based on the actual carbon content in the iron melt. They found a significant increase in the phosphate capacity of $\mathrm{Na}_{2} \mathrm{O}-\mathrm{SiO}_{2}$ slags by the addition of $\mathrm{Na}_{2} \mathrm{O}$. The results of Niekerk and Dippenaar [67] are in good agreement with those of Inoue and Suito [78] who performed similar experiments on the phosphorus distribution between $\mathrm{Na}_{2} \mathrm{O}-\mathrm{SiO}_{2}$ slags and hot metal at $1250{ }^{\circ} \mathrm{C}$ and $1350{ }^{\circ} \mathrm{C}$. A graph of Niekerk and Dippenaar's work is shown in Figure 2-17 together with the data previously reported by Inoue and Suito [78]. 


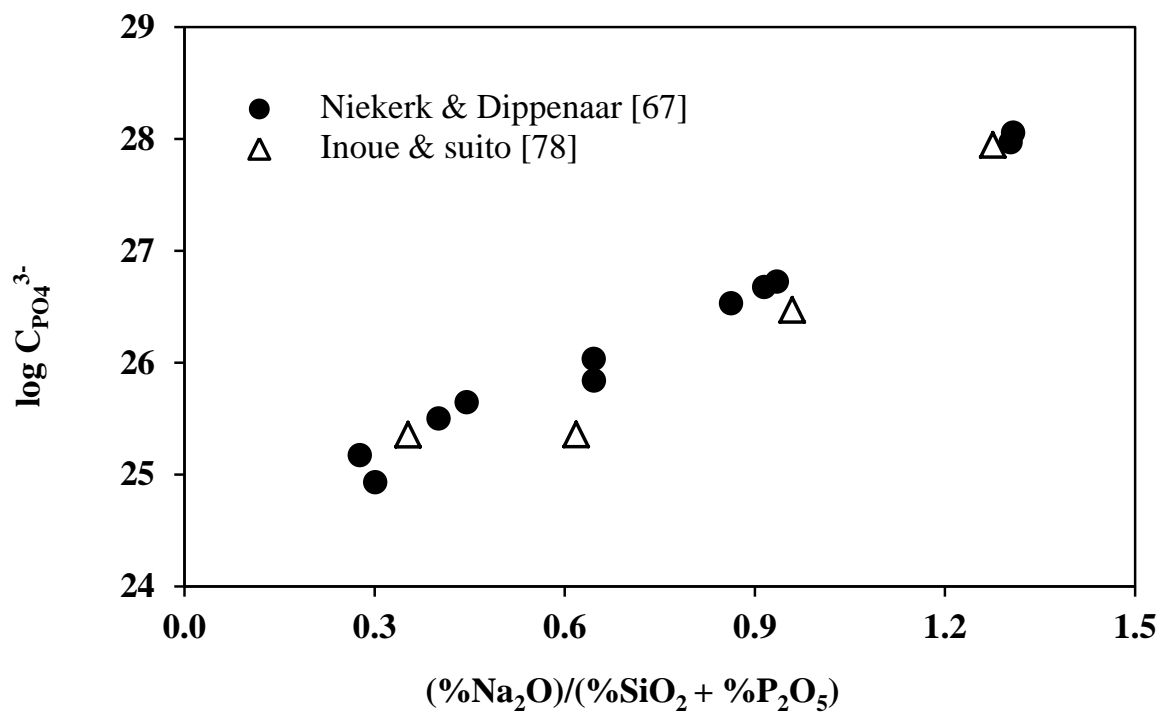

Figure 2-17: Phosphate capacity of $\mathrm{Na}_{2} \mathrm{O}-\mathrm{SiO}_{2}$ slags at $1350{ }^{\circ} \mathrm{C}$ [78]

Pak and Fruehan [81] investigated the equilibrium phosphorus partition ratio and phosphate capacity between $\mathrm{Na}_{2} \mathrm{O}-\mathrm{SiO}_{2}-\mathrm{P}_{2} \mathrm{O}_{5}$ slags and carbon saturated iron using a graphite crucible under $\mathrm{CO}$ or $\mathrm{Ar}-\mathrm{CO}$ at $1200{ }^{\circ} \mathrm{C}$. Their results showed that the equilibrium phosphorus partition ratio increases as the basicity increases and $L_{P}$ is independent of the $\mathrm{P}$ level in slag. The phosphate capacities for these slags were calculated from the measured phosphorus partition ratio and available thermodynamic data. The phosphate capacities are plotted as a function of basicity in Figure 2-18.

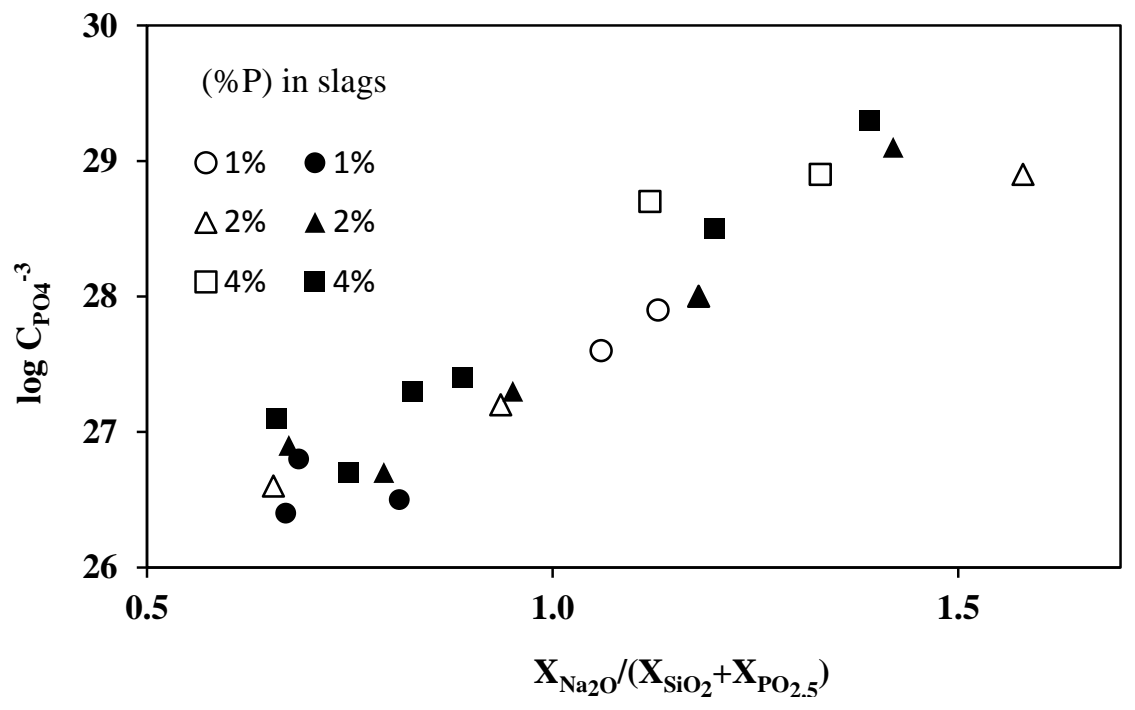

Figure 2-18: Phosphate capacity of $\mathrm{Na}_{2} \mathrm{O}-\mathrm{SiO}_{2}-\mathrm{P}_{2} \mathrm{O}_{5}$ slags at $1200{ }^{\circ} \mathrm{C}$ [81]

(Open symbol, $\mathrm{P}$ transfer from metal to slag and solid symbol, $\mathrm{P}$ transfer from slag to metal) 
The C-CO reaction $\left(P_{C O}=1 \mathrm{~atm}\right)$ sets the oxygen pressure $\left(P_{O_{2}}=8.45 \times 10^{-18} \mathrm{~atm}\right)$. It can be observed that the phosphate capacity has a linear correlation with basicity and is independent of the P level in slag.

Borode [82] studied the equilibrium phosphorus partition ratio and phosphate capacity between $\mathrm{Na}_{2} \mathrm{O}-\mathrm{SiO}_{2}$ melts and carbon saturated iron using a slag-metal equilibrium technique in graphite crucibles at $1400{ }^{\circ} \mathrm{C}$. The phosphate capacity data obtained in Borode's work was related to the optical basicity, Figure 2-19.

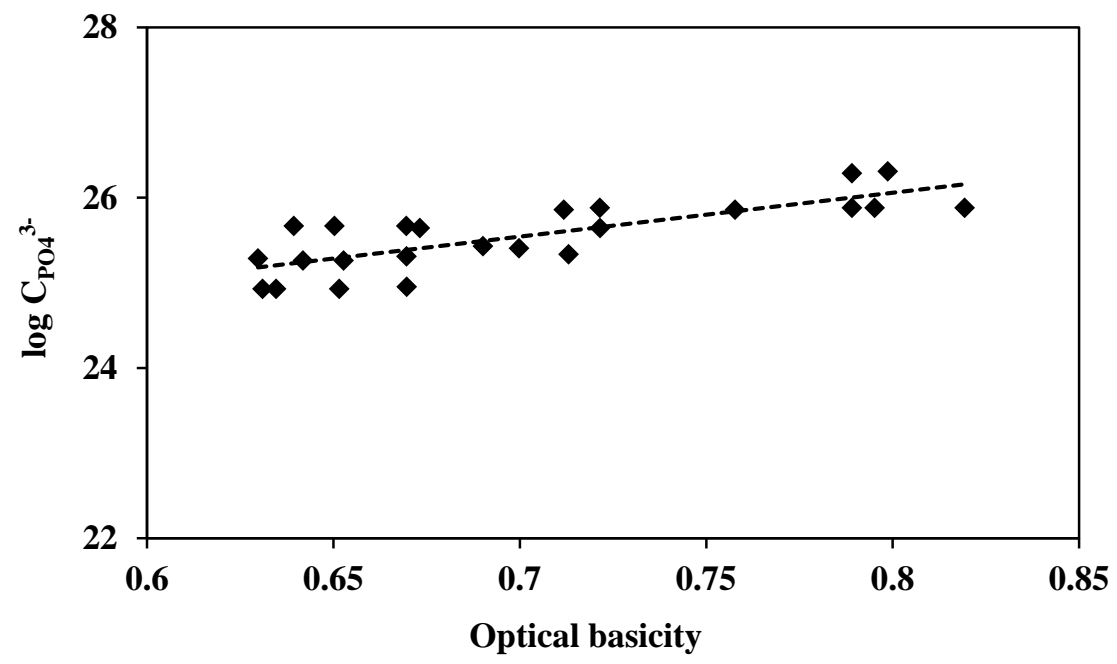

Figure 2-19: Relationship between phosphate capacity and optical basicity at $1400{ }^{\circ} \mathrm{C}$ [82]

\subsubsection{Lime based fluxes}

Environmental considerations over disposal of sodium containing slags and evolution of alkali fumes have enhanced the use of limestone-based reagents, which are often mixed with iron ore or sinter fines. Sasaki et al. [83] performed hot metal dephosphorization with a combination of a lime based flux and an oxidizing agent. Their experiments concentrated on BOF (basic oxygen furnace) and $\mathrm{CaO}-\mathrm{CaF}_{2}-\mathrm{FeO}_{\mathrm{x}}$ slags.

Essentially, slag-metal reactions during hot metal dephosphorization do not reach the equilibrium state. This is because the involved slags are usually highly oxidizing, containing high levels of iron and/or manganese oxides, which can be reacted with carbon dissolved in the hot metal and result in a violent $\mathrm{CO}$ evolution. It should be noted that the phosphorus distribution ratio is affected by oxygen potential in the slag-metal system and the oxygen potential can be 
represented by the $\mathrm{FeO}$ content in the slag system. Consequently, Iwasaki and Sano [84] developed a technique to indirectly measure the phosphorus distribution ratios between $\mathrm{CaO}-\mathrm{FeO}-\mathrm{SiO}_{2}$ slag and carbon saturated iron using an iron crucible in the temperature range of $1300{ }^{\circ} \mathrm{C}$ to $1380{ }^{\circ} \mathrm{C}$. They suggested the equilibrium distribution of phosphorus between a solid iron foil and a slag can be experimentally determined and then converted to distribution of phosphorus for carbon saturated iron using available thermodynamic data. In fact, the slag in equilibrium with solid iron could be equilibrated with the carbon saturated iron, as the chemical potential of phosphorus in solid iron is the same as that in carbon saturated iron [84].

Ito and Sano [85] employed a similar technique to investigate the phosphate capacity between basic slags and carbon saturated iron at $1300^{\circ} \mathrm{C}$. They found the $\mathrm{CaO}-\mathrm{SiO}_{2}-\mathrm{FeO}$ system shows high dephosphorization capacity when it is saturated with $2 \mathrm{CaO} \cdot \mathrm{SiO}_{2}$ and the addition of iron oxide to the basic slags decreases the phosphate capacity values (Figure 2-20). It can be seen that phosphate capacity for the $\mathrm{CaO}-\mathrm{SiO}_{2}-\mathrm{FeO}$ system (with $\mathrm{CaO} / \mathrm{SiO}_{2}=0.7$ or 0.8 ) increases from 19 to 20.5 with increasing $\mathrm{FeO}$. On the other hand, phosphate capacity for the slag saturated with $2 \mathrm{CaO} \mathrm{SiO}_{2}$ is close to 22 and slightly decreases with the increasing $\mathrm{FeO}$ content [85]. This can be explained by iron oxide slightly increasing or even decreasing the activity of oxygen ion $\left(\mathrm{a}_{\mathrm{O}}{ }^{-2}\right)$ in basic slags due to the amphoteric property of $\mathrm{FeO}$ and because of the quite repulsive interaction with phosphate ion which increases activity coefficient of phosphate ion $\left(\mathrm{f}_{\mathrm{PO}_{4}^{-3}}\right)$ [85].

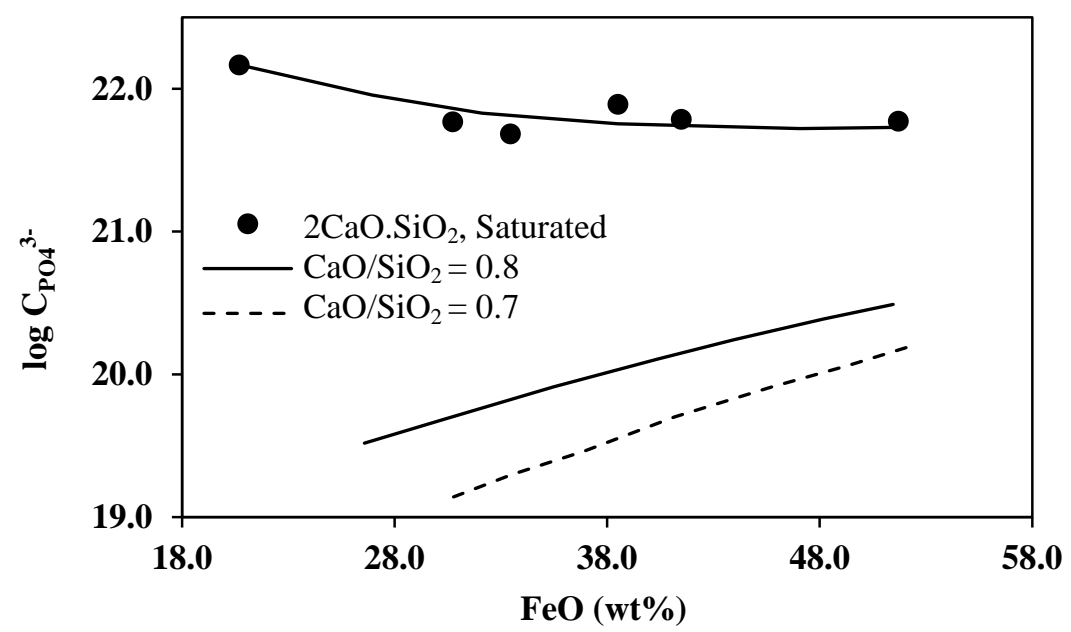

Figure 2-20: Relationship between the phosphate capacity and $\mathrm{FeO}\left(\mathrm{wt} \%\right.$ ) for the $\mathrm{CaO}-\mathrm{SiO}_{2}-\mathrm{FeO}$ system at $1300{ }^{\circ} \mathrm{C}[85]$ 
Muraki et al. [86] measured the composition and temperature dependence of the phosphate capacity of $\mathrm{CaO}-\mathrm{CaF}_{2}-\mathrm{SiO}_{2}$ slags by performing a slag metal equilibrium technique at temperatures of $1200{ }^{\circ} \mathrm{C}$ to $1400{ }^{\circ} \mathrm{C}$. Muraki et al. stated that in liquid slag as an ionic solution, dephosphorization is facilitated by increasing the activity of oxygen ion and decreasing the activity coefficient of phosphate ion at constant temperature. They showed that fluxes with $\mathrm{CaCl}_{2}$ or $\mathrm{CaF}_{2}$ without $\mathrm{FeO}$ have higher $\mathrm{C}_{\mathrm{PO}_{4}^{3-}}$ compared to fluxes that contain a large amount of $\mathrm{FeO}$. As a result, $\mathrm{FeO}$ in highly basic slags behaves like as an acidic oxide. The results of Muraki et al. are shown in Figure 2-21, which are in good agreement with those reported earlier by others $[85]$.

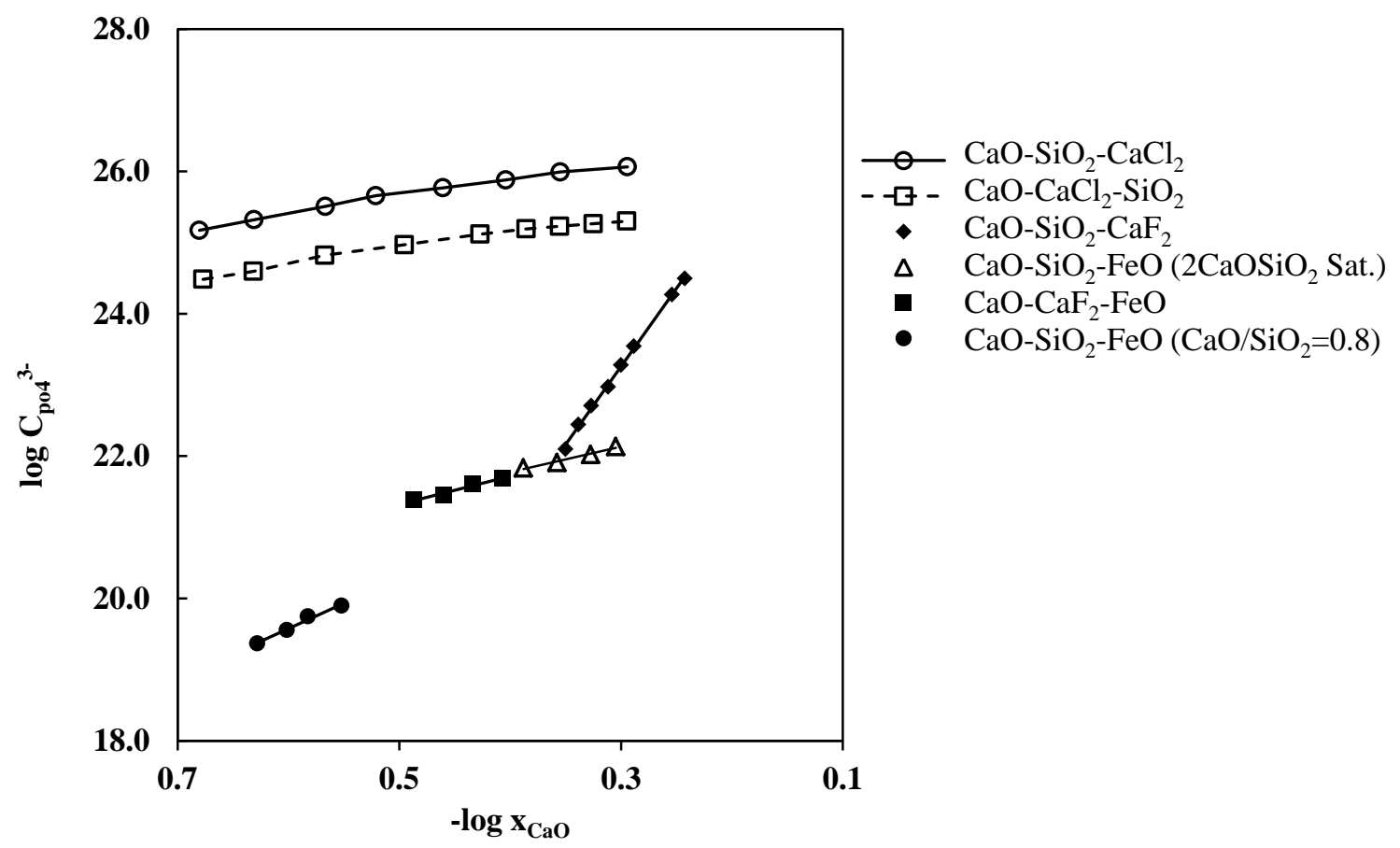

Figure 2-21: Phosphate capacity of various slag system containing $\mathrm{CaO}$ [86]

Werme et al. [87] also used the Iwasaki and Sano [84] technique to measure distribution of phosphorus between $\mathrm{CaO}-\mathrm{FeO}-\mathrm{SiO}_{2}-\mathrm{P}_{2} \mathrm{O}_{5}$ slag containing $10 \% \mathrm{P}_{2} \mathrm{O}_{5}$ and carbon saturated iron at $1300^{\circ} \mathrm{C}$. Their results indicated that for slags saturated with $(\mathrm{C} 2 \mathrm{~S}-\mathrm{C} 3 \mathrm{P})$ the highest distribution ratio was at $35 \mathrm{wt} \% \mathrm{FeO}$. On the other hand, Werme et al. [87] showed that the maximum distribution shifted to higher FeO levels for unsaturated slags Figure 2-22. 


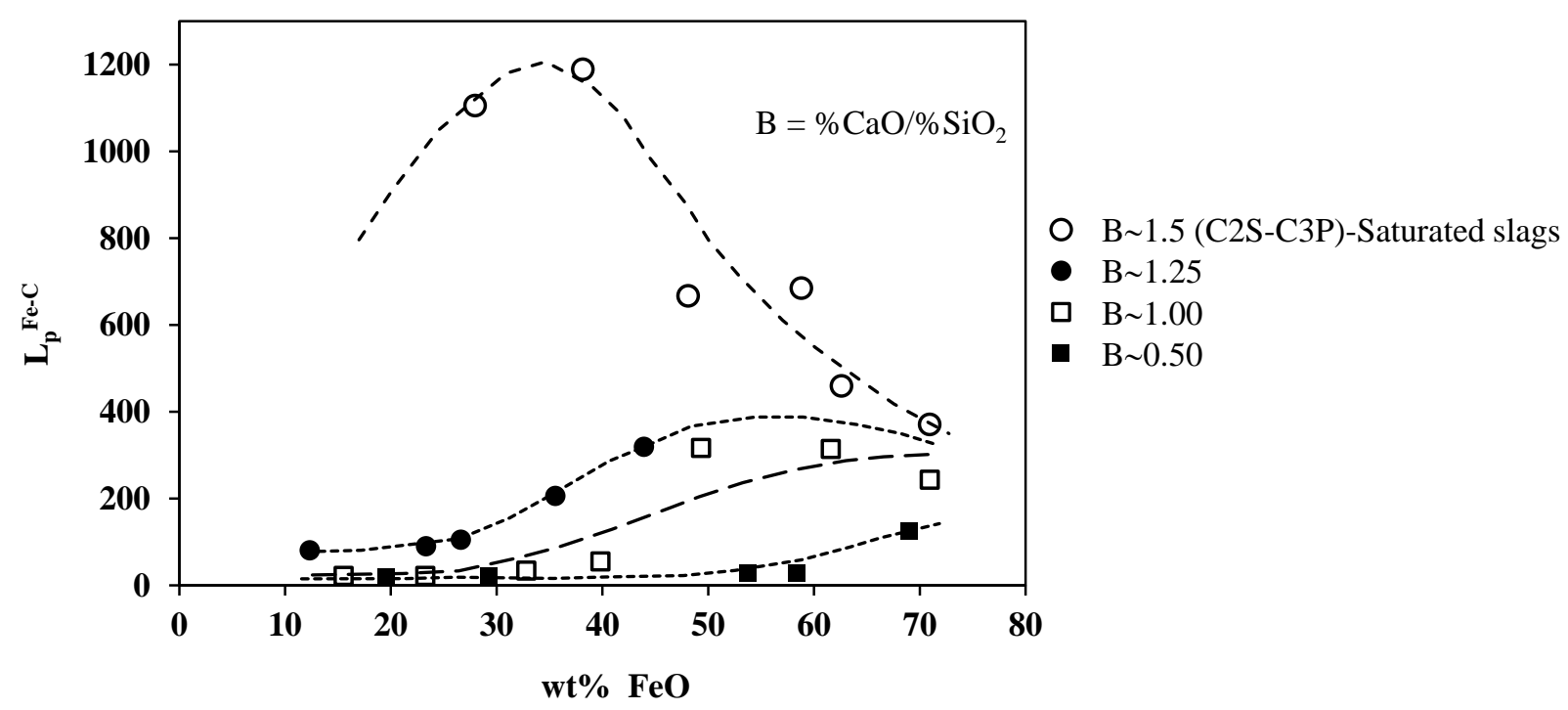

Figure 2-22: Variation in phosphorus distribution with FeO content at different basicities [87]

They stated that the behavior is a result of the combined effects of $\mathrm{CaO}$ and $\mathrm{FeO}$ concentration in the slag. With increasing the $\mathrm{FeO}$ concentration beyond a certain level (corresponding to maximum $L_{P}$ ), the positive effect of the increase in oxygen potential on the $L_{P}$ cannot be balanced against the negative effect of the decrease in $\mathrm{CaO}$ activity and vice versa [87]. A graph of their data along with of the results Ito and Sano [85] is plotted in Figure 2-23. It can be seen that the maximum distribution ratio is lower for the $\mathrm{CaO}-\mathrm{FeO}-\mathrm{SiO}_{2}$ slags with low phosphorus content [87].

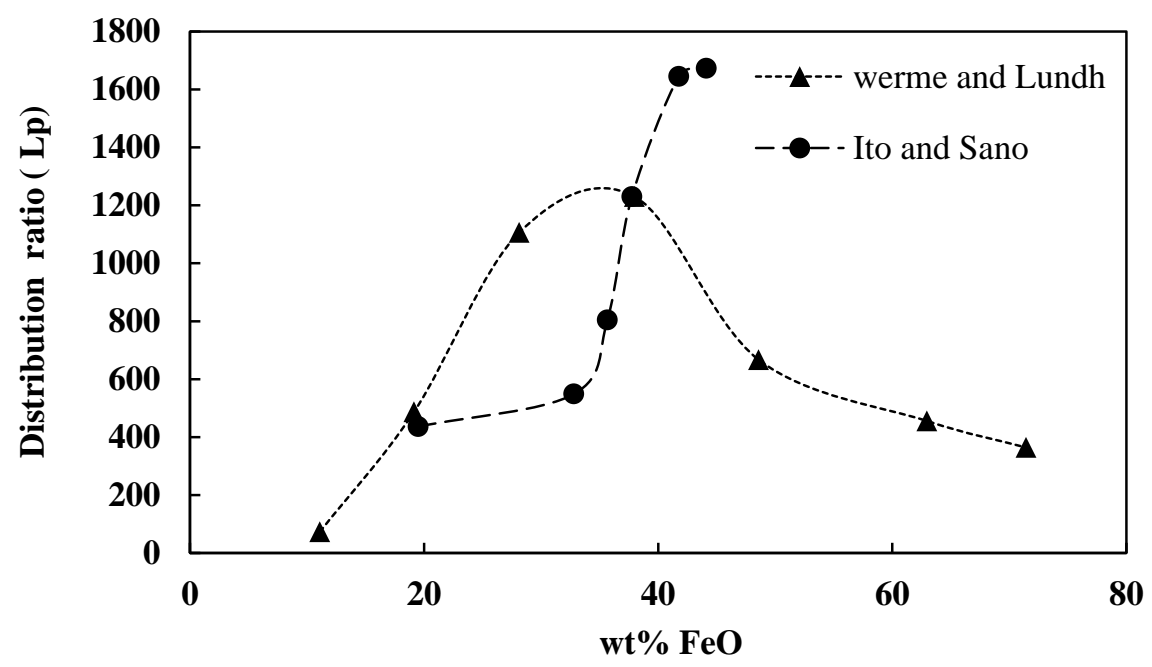

Figure 2-23: Equilibrium phosphorus distribution between $\left(\mathrm{C}_{2} \mathrm{~S}-\mathrm{C}_{3} \mathrm{P}\right)_{\mathrm{SS}}$ saturated slags and carbon saturated iron at $1300{ }^{\circ} \mathrm{C}$ [87] 
Yang et al. [64] and coworkers investigated the effect of temperature on the phosphate capacity of $\mathrm{CaO}-\mathrm{CaCl}_{2}$ slags at $1175^{\circ} \mathrm{C}-1350{ }^{\circ} \mathrm{C}$. Figure 2-24 shows the logarithm of slag phosphate capacity against the reciprocal of the absolute temperature for the slags containing $\mathrm{CaO}$ and $\mathrm{CaCl}_{2}$. They found that the slag phosphate capacity decreases with increasing temperature and increases with increasing $\mathrm{CaO}$ content.

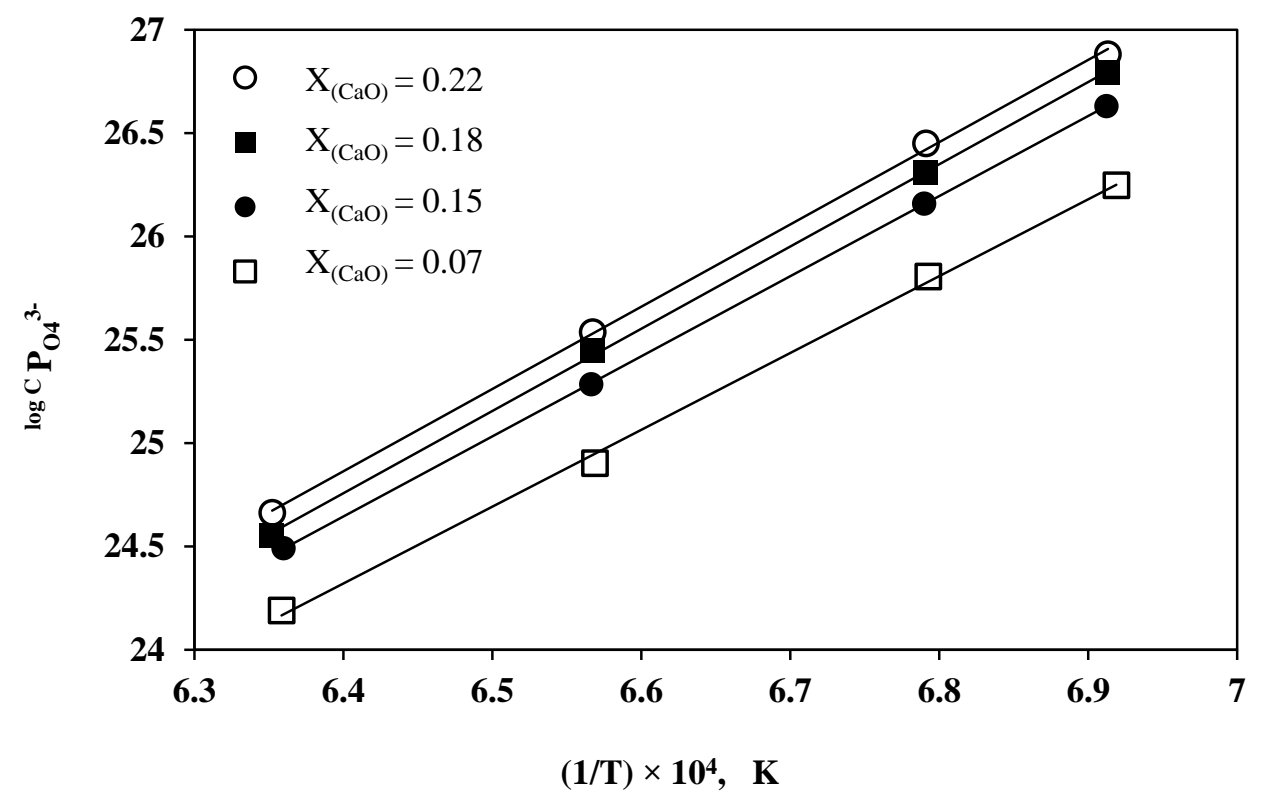

Figure 2-24: Effect of temperature on phosphate capacity of $\mathrm{CaO}-\mathrm{CaCl}_{2}$ slags [64]

As explained earlier (Sec. 2.2.3) the proposed research is aimed at an investigating of the fundamental aspects of using a waste material that is high in iron oxide, for the refining treatment of hot metal as well as molten steel. This will require physical and chemical characterization of the waste components as well as design and thermo-chemical evaluation of synthetic fluxes for desulphurization and dephosphorization. 


\section{Chapter 3}

\section{Experimental Aspects}

This chapter presents details of the experimental work related to the research. The first section concentrates on the red mud characterization techniques. The second section describes experiments involving measurements of the sulphide capacity of red mud based fluxes. The third section provides details on the measurements of the phosphorus partition ratio between synthetic red mud based fluxes and carbon saturated iron. The final section describes the experiments, methods and materials for studying the melting behavior of red mud based fluxes.

\subsection{Characterization of red mud}

In order to characterize red mud, fresh alkaline suspension $(\approx 30 \%$ water content $)$ from Alcoa Inc. (Aluminum Company of America) was used, Figure 3-1 (a). This red mud was produced through the Bayer process for extraction of alumina. The slurry was placed in a Pyrex container and dried in an electric oven at $105^{\circ} \mathrm{C}$ for $75 \mathrm{hr}$. The dried red mud Figure 3-1 (b) was crushed and sieved to pass a 250 mesh sieve, and then a combination of XRF (X-Ray Fluorescence Spectroscopy), XRD (X-Ray Diffraction), TGA (Thermal Gravimetric Analysis), DSC (Differential Scanning Calorimetry) and SEM (Scanning Electron Microscope) techniques were used to characterize the structure and determine the concentrations of various impurities present in the red mud.

\subsubsection{X-Ray diffraction analysis}

The phase analysis of the red mud was studied using a Philips diffractometer PW3710 with a nickel filter to produce a monochromatic copper $\mathrm{k}_{\alpha 1}$ radiation $(\lambda=1.54 \mathrm{~A})$ and a proportional detector to capture the scattered copper X-rays. The voltage and current were $40 \mathrm{kV}$ and $40 \mathrm{~mA}$ respectively. The step size of $2 \theta=0.03$ degree and time per step of 5 second were adjusted to obtain diffraction peaks with highest intensity. The $2 \theta$ diffraction angle range of $5^{\circ}-90^{\circ}$ was covered. The results were compared with the International Centre for Diffraction Data (ICDD) databases using $X^{\prime}$ High Score software for peak identification. 


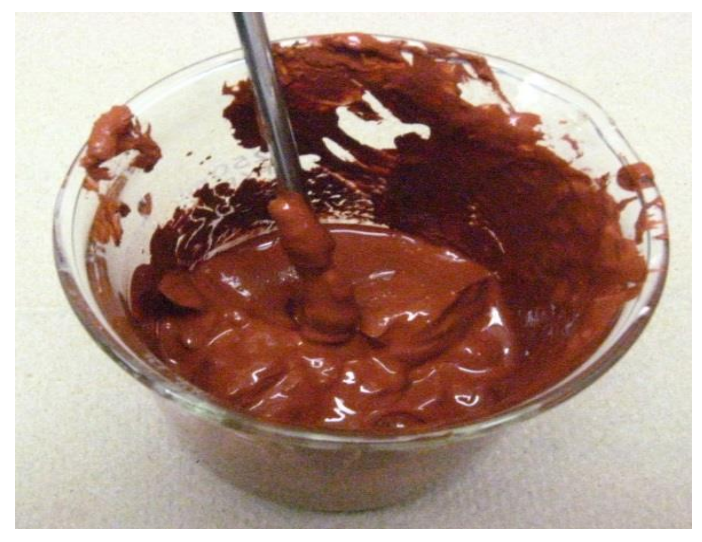

(a)

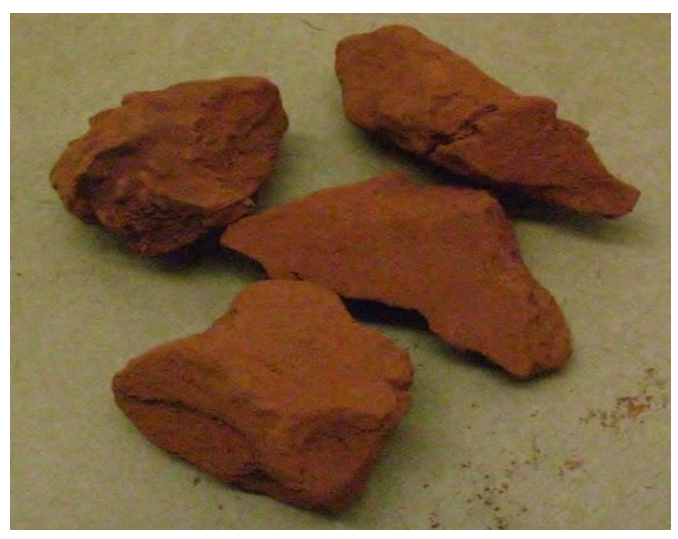

(b)

Figure 3-1: Red mud from Bayer process; (a) Fresh red mud; (b) Dried red mud

\subsubsection{XRF analysis}

The qualitative chemical analysis of the red mud was performed with a Philips 2440 X-ray fluorescence spectrometer. Each sample was pressed into a disk with the addition of a binder (boric acid) and using a hydraulic press operating at a pressure of $70 \mathrm{MPa}$. The XRF data were analyzed using a Philips software package which is capable of detecting all elements between fluorine $(\mathrm{N}=9)$ and uranium $(\mathrm{N}=92)$.

\subsubsection{TGA and DSC}

The thermal behavior of red mud was evaluated using a Netzsch Simultaneous Thermal Analyzer STA 449 F3 Jupiter System for high quality TGA and DSC measurements. This simultaneous thermal analysis (STA) apparatus can be used for determining mass change with thermogravimetric analysis and transformation temperatures and enthalpies with differential scanning calorimetry. Dried red mud (15 mg) was placed into an alumina pan and situated on a special pedestal which was attached to the thermobalance assembly. The resolution of this low drift microbalance was $1 \mu \mathrm{g}$.

The STA 449 F3 Jupiter system continuously measured changes in sample weight as heat was supplied to the sample. The experimental conditions employed were heating rate of $10{ }^{\circ} \mathrm{C} / \mathrm{min}$ and temperature range of $25^{\circ} \mathrm{C}$ to $1400{ }^{\circ} \mathrm{C}$ under a $99.999 \%$ Argon (Grade 5) atmosphere. The collected data were analyzed by the Proteus Software package. 


\subsubsection{Particle size analysis}

A Horiba LA-950 unit was used to analyze the particle size distribution of red mud. With this method, a powder sample was suspended in water with the aid of a stirrer and ultrasonic waves, and then exposed to a laser beam which scatters as it strikes the particles. The results were analyzed with appropriate software to give the size distribution of the particles within the suspension.

\subsubsection{ICP analysis}

Optima 7300 ICP-AES (Inductively Coupled Plasma Atomic Emission Spectrometry) was used to analyze the minor elements of red mud. Samples for analysis by ICP were prepared by acid digestion with nitro-hydrochloric acid $\left(\mathrm{HNO}_{3}+3 \mathrm{HCl}\right)$. The ICP experimental details are given in Appendix 1.

\subsection{Desulphurization experiments}

Sulphur partition studies of a set of red mud based fluxes were conducted under reducing conditions. The slag-metal equilibrium technique was adapted to assess the effect of chemical composition and temperature on the sulphur partition between red mud based fluxes and hot metal from $1300{ }^{\circ} \mathrm{C}$ to $1400{ }^{\circ} \mathrm{C}$ in a carbon monoxide atmosphere. Graphite crucibles were used as containers of molten slag and hot metal.

\subsubsection{Materials}

The chemicals used and their purity grades for desulphurization studies are shown in Appendix 2 (Table. A2-1).

\subsubsection{Carbon saturated iron preparation}

Reducing conditions and high operating temperature are favorable for sulphur removal in hot metal pretreatment. The hot metal (carbon saturated iron) was prepared by melting $500 \mathrm{~g}$ of electrolytic iron pieces and $20 \mathrm{~g}$ of graphite powder and iron sulphide (FeS) in a graphite crucible at $1450{ }^{\circ} \mathrm{C}$ using a $30 \mathrm{~kW}$ induction furnace. After melting, the liquid metal was poured into cold water for rapid solidification in order to prevent any sulphur segregation during solidification. The solidified carbon saturated iron was analyzed using the LECO C/S 
combustion analyzer as well as Inductively Coupled Plasma (ICP) methods. The sample was digested by adding nitric acid $\left(\mathrm{HNO}_{3}\right)$ and deionized water. A more detail is presented in Appendix 1(Sec. A1.1). The solidified carbon saturated iron lumps were used for desulphurization experiments. The composition of the electrolytic iron and the final carbon saturated iron is given in Table 3-1.

Table 3-1: Chemical composition of electrolytic iron and prepared carbon saturated iron (wt \%)

\begin{tabular}{|c|c|c|c|c|c|c|}
\hline Material & Carbon & Manganese & Silicon & Sulphur & Phosphorus & Iron \\
\hline Electrolytic iron* & 0.0007 & 0.0016 & 0.001 & 0.002 & 0.0006 & Balance \\
\hline Carbon saturated iron & $4.31-4.65$ & $0.21-0.38$ & $0.33-0.40$ & $0.18-0.20$ & $0.001-0.005$ & Balance \\
\hline
\end{tabular}

* Based on supplier information

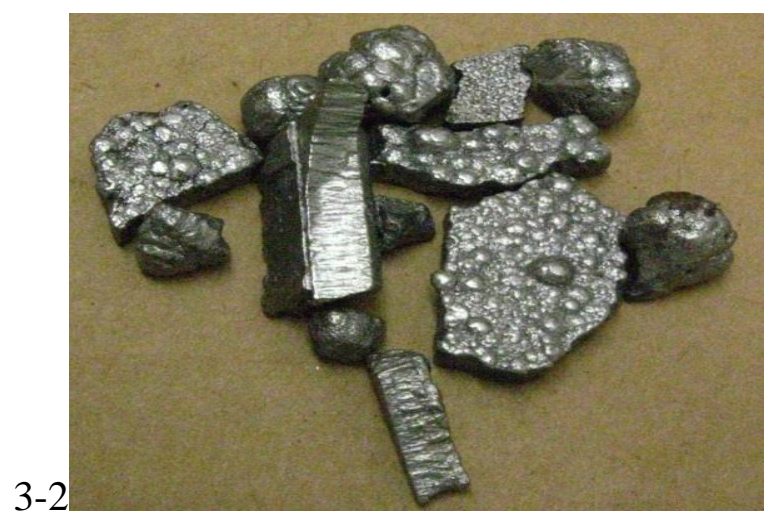

(a)

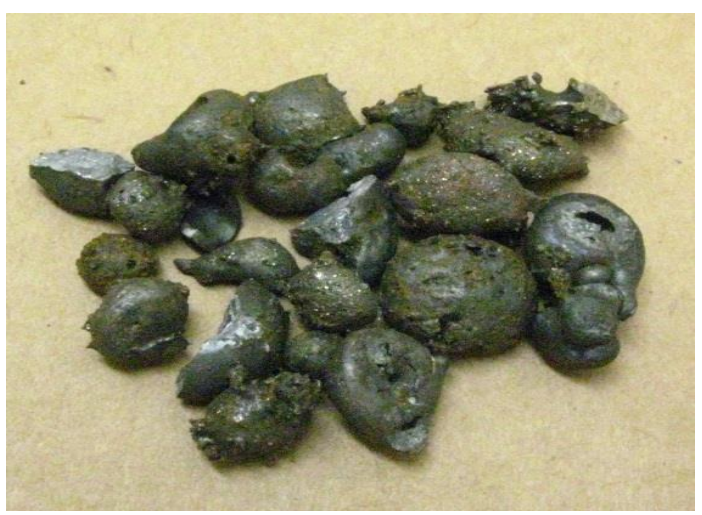

(b)

Figure 3-2: Electrolytic iron and carbon saturated iron

\subsubsection{Flux components}

The synthetic fluxes were prepared from the dried red mud and additives of reagent grade calcium oxide, titanium oxide, silicon oxide, and alumina. The oxides were calcined at $800{ }^{\circ} \mathrm{C}$ for $2 \mathrm{hr}$. The target flux compositions and their optical basicities are listed in Table 3-2. These compositions were designed to examine the influence of various oxides on the desulphurization. Fluxes RMF1 to RMF6 containing increasing amounts of lime were used to establish the effect of lime content in the flux. Fluxes RMF7 to RMF10 will show the effect of alumina, and fluxes RMF11 to RMF14 and RMF15 to RMF18 are meant to establish the effects of titania and silica respectively on the desulphurization properties. 


\subsubsection{Furnace}

A schematic diagram of the experimental arrangement is given in Figure 3-3. As seen, the furnace used in this work was a vertical tube furnace with $\mathrm{MoSi}_{2}$ heating elements and a gastight alumina $69.85 \mathrm{~mm}$ (OD) $63.5 \mathrm{~mm}$ (ID) working tube. The tube was sealed by two water cooled aluminum caps on both ends to maintain a reducing atmosphere by purging carbon monoxide through the tube. The temperature was controlled using a proportional integral derivative (PID) controller and B-type (Pt30\% Rh - Pt/6\% Rh) thermocouple. A separate R-type $(\mathrm{Pt} / \mathrm{Pt}-13 \% \mathrm{Rh})$ thermocouple was inserted from the bottom of the furnace and placed in contact with the bottom of the graphite crucible during the experiment. Accuracy of temperature control was obtained using a USB data acquisition device. The maximum observed variation from the set point was recorded $\left( \pm 1^{\circ} \mathrm{C}\right)$ at $1400{ }^{\circ} \mathrm{C}$. The temperature profile inside the tube is plotted in Figure 3-4 to ensure that the crucible was located in the hot and uniform-temperature zone of the furnace. The thermocouples were tested with a FLUKE 814 temperature calibrator which was also used to measure the response of the temperature data acquisition system. The calibration error for B-type and R-type thermocouples was $\pm 3{ }^{\circ} \mathrm{C}$ and $\pm 2.5^{\circ} \mathrm{C}$, respectively.

Table 3-2: Flux compositions used in the desulphurization study

\begin{tabular}{|c|c|c|c|}
\hline Heat No. & Flux Composition & $\begin{array}{c}\text { Basicity } \\
\text { (B) }\end{array}$ & $\begin{array}{l}\text { Optical basicity } \\
(\Lambda)\end{array}$ \\
\hline RMF1 & 100RM & 0.34 & 0.72 \\
\hline RMF2 & $90 \mathrm{RM}+10 \mathrm{CaO}$ & 1.3 & 0.73 \\
\hline RMF3 & $80 \mathrm{RM}+20 \mathrm{CaO}$ & 2.5 & 0.75 \\
\hline RMF4* & $70 \mathrm{RM}+30 \mathrm{CaO}$ & 4.1 & 0.76 \\
\hline RMF5 & $60 \mathrm{RM}+40 \mathrm{CaO}$ & 6.1 & 0.78 \\
\hline RMF6 & $50 \mathrm{RM}+50 \mathrm{CaO}$ & 9.0 & 0.80 \\
\hline RMF7 & $90 \mathrm{RMF} 4+10 \mathrm{Al}_{2} \mathrm{O}_{3}$ & 4.1 & 0.74 \\
\hline RMF8 & $85 \mathrm{RMF} 4+15 \mathrm{Al}_{2} \mathrm{O}_{3}$ & 4.1 & 0.74 \\
\hline RMF9 & $80 \mathrm{RMF} 4+20 \mathrm{Al}_{2} \mathrm{O}_{3}$ & 4.1 & 0.73 \\
\hline RMF10 & $75 \mathrm{RMF} 4+25 \mathrm{Al}_{2} \mathrm{O}_{3}$ & 4.1 & 0.72 \\
\hline RMF11 & $95 \mathrm{RMF} 4+5 \mathrm{TiO}_{2}$ & 4.1 & 0.76 \\
\hline RMF12 & 92RMF4+8TiO 2 & 4.1 & 0.76 \\
\hline RMF13 & $88 \mathrm{RMF} 4+12 \mathrm{TiO}_{2}$ & 4.1 & 0.76 \\
\hline RMF14 & $85 \mathrm{RMF} 4+15 \mathrm{TiO}_{2}$ & 4.1 & 0.76 \\
\hline RMF15 & 90RMF4+10 $\mathrm{SiO}_{2}$ & 1.8 & 0.74 \\
\hline RMF16 & $85 \mathrm{RMF} 4+15 \mathrm{SiO}_{2}$ & 1.4 & 0.73 \\
\hline RMF17 & $80 \mathrm{RMF} 4+20 \mathrm{SiO}_{2}$ & 1.2 & 0.72 \\
\hline RMF18 & $75 \mathrm{RMF} 4+25 \mathrm{SiO}_{2}$ & 1.0 & 0.70 \\
\hline
\end{tabular}

RMF4 ${ }^{*}$ : Flux composition contains $70 \mathrm{RMF}+30 \mathrm{CaO}$ 


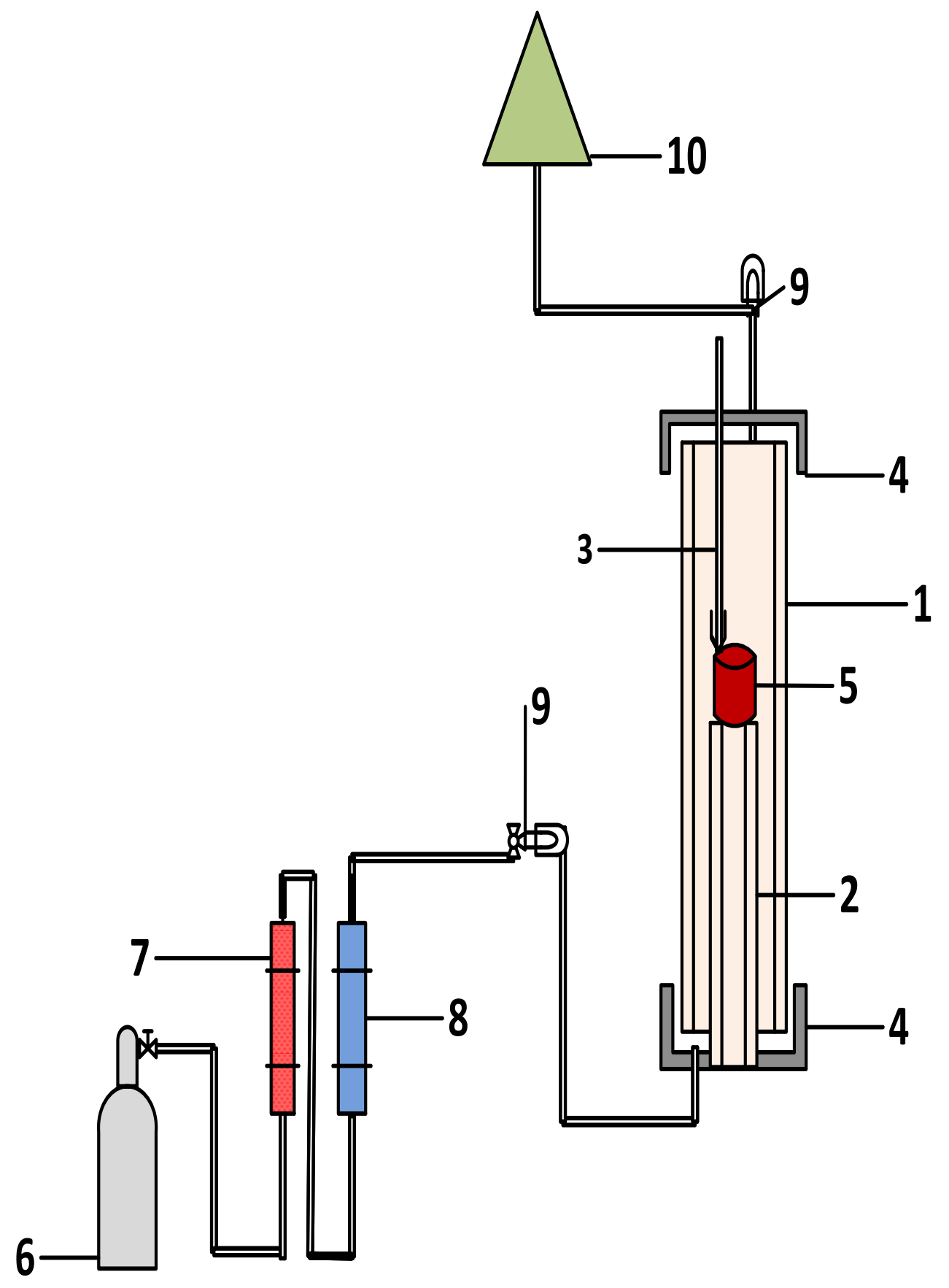

(1) Alumina tube, (2) Alumina pedestal, (3) Thermocouple, (4) Water cooled aluminum caps, (5) Graphite crucible, (6) Carbon monoxide gas, (7-8) Gas purifier units, (9) Gas bubbling indicator, (10) Exhaust with burner

Figure 3-3: Schematic diagram of the experimental set up for the vertical furnace 


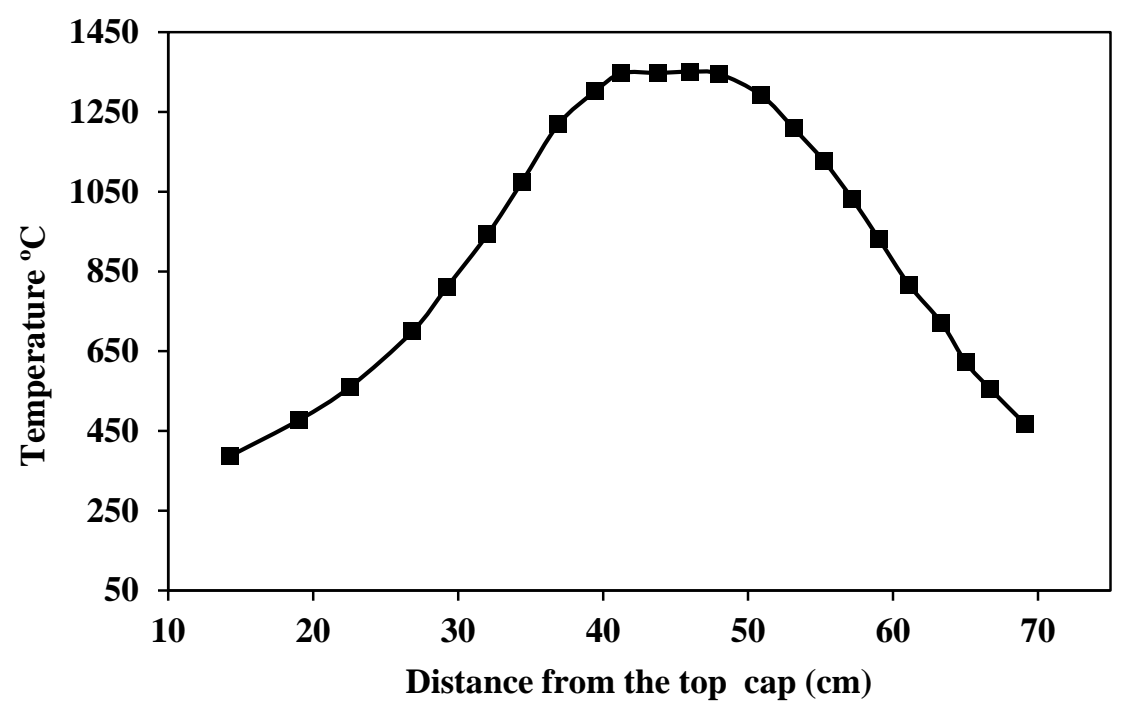

Figure 3-4: Temperature profile in the vertical tube furnace

\subsubsection{Experimental procedure}

The experiments were carried out on all compositions which are listed in Table 3-2 at various temperatures from $1300{ }^{\circ} \mathrm{C}$ to $1400{ }^{\circ} \mathrm{C}$. The values for the flux basicity, defined as $\mathrm{B}=\frac{\% \mathrm{CaO}}{\% \mathrm{SiO}_{2}}$ or optical basicity are also listed in Table 3-2. Preliminary experiments were performed to obtain the time required to reach equilibrium.

Before running each experiment, four holes (diameter $17 \mathrm{~mm}$ and depth $60 \mathrm{~mm}$ ) were made in a cylindrical graphite block (Diameter: $50 \mathrm{~mm}$ ) so that each hole acted as one crucible and in each run, four samples were examined. Each hole contained $10 \mathrm{~g}$ of carbon saturated iron and $5 \mathrm{~g}$ of slag materials that were weighed and mixed and then added in the crucible. The graphite crucible was then placed on an alumina pedestal and lifted into the furnace.

Subsequently, the furnace was sealed and argon was passed through the furnace at $250 \mathrm{~mL} / \mathrm{min}$ for $10 \mathrm{~min}$ to flush air out of the furnace. At this point, CO purge started and the furnace was heated to the desired temperature. Holding time for achieving equilibrium was $30 \mathrm{hr}$. The flow rate of $\mathrm{CO}$ was maintained constant at $60 \mathrm{~mL} / \mathrm{min}$ in all runs. The crucible containing the molten slag and metal was then taken out from the furnace and submerged in water to the level of the molten material inside the crucible. 
After quenching, the graphite crucible was cut and the slag and solid metal were removed from the crucible. Any metallic particles were manually removed from the slag with a magnet.

Slag samples were then crushed and ground to a fine powder using a puck mill and were kept in sealed glass containers. The metal and slag phases were analyzed using the LECO C/S combustion analyzer as well as X-ray fluorescence and Inductively Coupled Plasma (ICP) methods Appendix 1 (Sec. A1.1 - Sec. A1.2).

\subsection{Dephosphorization experiments}

The objective of this part of the work was to investigate the effect of temperature and slag composition on the phosphorus partition ratio.

The slag-metal equilibrium technique was employed to evaluate the effect of temperature, iron oxide and other common oxides on the distribution of phosphorus between synthetic red mud and hot metal from $1300{ }^{\circ} \mathrm{C}$ to $1400{ }^{\circ} \mathrm{C}$. Fundamentally, red mud based fluxes that contain high amounts of iron oxide cannot reach equilibrium with carbon saturated hot metal at high temperatures as iron oxide will react with the dissolved carbon, rendering the flux essentially free of iron oxide. To avoid such difficulty, it is possible to measure the phosphorus distribution of fluxes containing iron oxide indirectly using the solid iron foil technique [84]. This method involves equilibration between synthetic red mud fluxes and a solid iron foil in an ARMCO iron crucible under the inert atmosphere of argon. After equilibration, the slags were quenched, dried, crushed and analyzed using XRF and ICP techniques. The equilibrium phosphorus distribution was then determined and the results were converted to the equilibrium phosphorus distribution for the carbon saturated system, using the thermodynamic data.

\subsubsection{Materials}

The characteristics of the materials used in dephosphorization experiments are listed in Appendix 2 (Table A2-2).

\subsubsection{Iron oxide preparation}

The primary component, $100 \mathrm{~g} \mathrm{Fe}_{2} \mathrm{O}_{3}$ and $15 \mathrm{~g}$ reagent grade $\mathrm{Fe}$ powder were first heated at $1400{ }^{\circ} \mathrm{C}$ for $15 \mathrm{~h}$ in $\mathrm{ARMCO}$ soft iron crucibles under argon atmosphere to obtain $\mathrm{FeO}$ : 
$\mathrm{Fe}_{2} \mathrm{O}_{3}+\mathrm{Fe} \rightleftharpoons 3 \mathrm{FeO}$

The crucible was quickly taken out of the furnace and quenched in cold water. After cooling, the solid material inside the crucible was removed and then ground to a fine powder and stored in an airtight glass container for secondary experiments as the iron oxide phase of the flux. XRD analysis on the solid material was performed and confirmed that $\mathrm{FeO}$ was the dominant phase.

\subsubsection{Flux components}

Different compositions were designed to investigate the influence of various oxides and temperature on the dephosphorization ability of the flux. The flux components are listed in Table 3-3. Fluxes SRM1 to SRM6 containing increasing amounts of lime were used to establish the influence of lime and iron oxide content. Fluxes SRM7 to SRM10 represent different levels of alumina. Fluxes SRM11 to SRM14 and SRM15 to SRM18 were used to evaluate the effect of titania and silica respectively on the dephosphorization properties.

\subsubsection{Furnace}

The furnace used in this work was a horizontal tube furnace with $6 \mathrm{MoSi}_{2}$ heating elements and a gas tight alumina tube, $69.85 \mathrm{~mm}$ (OD) and $63.5 \mathrm{~mm}$ (ID), which was supplied by the McDaniel Refractory Co. A schematic diagram of the experimental arrangement is given in Figure 3-5. The temperature was controlled using two thermocouples, similar to the desulphurization experiments (Sec 3.2.4). The atmosphere in the alumina tube was controlled by introducing high purity argon by passing the gas first through a gas train and an oxygen getter furnace to remove moisture, oxygen, and carbon dioxide.

The temperature profile along the length of the furnace was obtained to determine the hot zone of the furnace (Figure 3-6). During this procedure, both ends of the heating tube were covered by water cooled aluminum caps. The accuracy of the data acquisition system was measured by the FLUKE 814 temperature calibrator. The maximum discrepancy between the FLUKE 814 temperature calibrator and the temperature recorded by the data acquisition system was $\pm 1{ }^{\circ} \mathrm{C}$. The total measurement error for B-type and R-type thermocouples was evaluated $\pm 3{ }^{\circ} \mathrm{C}$ and $\pm 2.5^{\circ} \mathrm{C}$, respectively. 
Table 3-3: Flux compositions used in the dephosphorization study

\begin{tabular}{|c|c|}
\hline Heat No. & Flux Composition \\
\hline SRM-1 & $90 \mathrm{RM}+10 \mathrm{P}_{2} \mathrm{O}_{5}$ \\
\hline SRM-2 & $80 \mathrm{RM}+10 \mathrm{P}_{2} \mathrm{O}_{5}+10 \mathrm{CaO}$ \\
\hline SRM-3 & $70 \mathrm{RM}+10 \mathrm{P}_{2} \mathrm{O}_{5}+20 \mathrm{CaO}$ \\
\hline SRM-4 & $60 \mathrm{RM}+10 \mathrm{P}_{2} \mathrm{O}_{5}+30 \mathrm{CaO}$ \\
\hline SRM-5 & $50 \mathrm{RM}+10 \mathrm{P}_{2} \mathrm{O}_{5}+40 \mathrm{CaO}$ \\
\hline SRM-6 & $40 \mathrm{RM}+10 \mathrm{P}_{2} \mathrm{O}_{5}+50 \mathrm{CaO}$ \\
\hline SRM-7 & 90SRM5+10 $\mathrm{Al}_{2} \mathrm{O}_{3}$ \\
\hline SRM-8 & $85 \mathrm{SRM} 5+15 \mathrm{Al}_{2} \mathrm{O}_{3}$ \\
\hline SRM-9 & $80 \mathrm{SRM} 5+20 \mathrm{Al}_{2} \mathrm{O}_{3}$ \\
\hline SRM-10 & $75 \mathrm{SRM} 5+25 \mathrm{Al}_{2} \mathrm{O}_{3}$ \\
\hline SRM-11 & $95 \mathrm{SRM}+5 \mathrm{TiO}_{2}$ \\
\hline SRM-12 & $92 \mathrm{SRM}+8 \mathrm{TiO}_{2}$ \\
\hline SRM-13 & $88 \mathrm{SRM} 5+12 \mathrm{TiO}_{2}$ \\
\hline SRM-14 & $85 \mathrm{SRM} 5+15 \mathrm{TiO}_{2}$ \\
\hline SRM-15 & $90 \mathrm{SRM} 5+10 \mathrm{SiO}_{2}$ \\
\hline SRM-16 & $84 \mathrm{SRM}+15 \mathrm{SiO}_{2}$ \\
\hline SRM-17 & $80 \mathrm{SRM} 5+20 \mathrm{SiO}_{2}$ \\
\hline SRM-18 & $75 \mathrm{SRM} 5+25 \mathrm{SiO}_{2}$ \\
\hline
\end{tabular}

SRM5 ${ }^{*}$ : Flux composition contains $50 \mathrm{RM}+10 \mathrm{P}_{2} \mathrm{O}_{5}+40 \mathrm{CaO}$ 


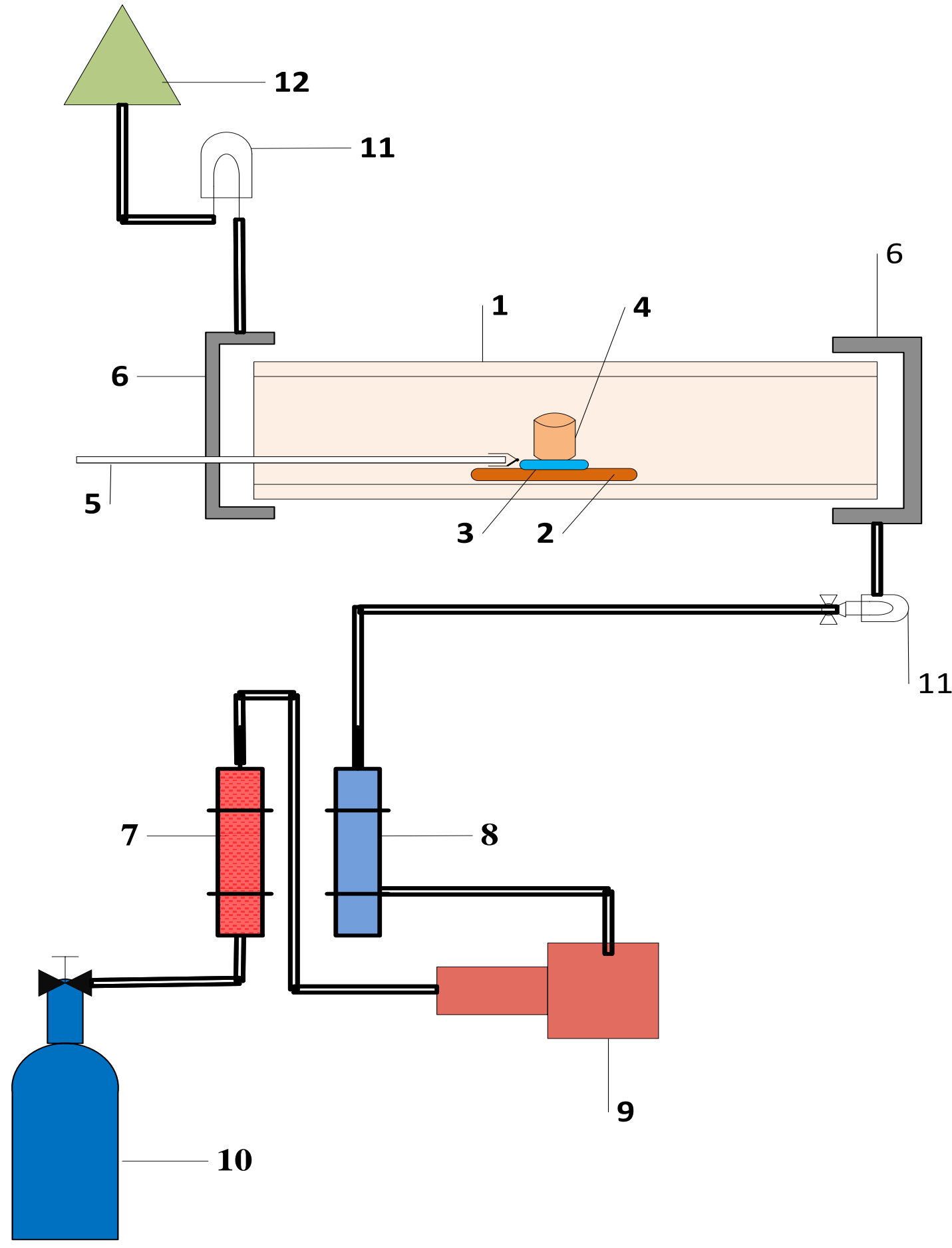

(1) Alumina tube, (2) Alumina holder, (3) Ziconia substrate, (4) Iron crucible, (5) Thermocouple, (6) Water cooled aluminum caps, (7) Gas drying column, (8) Gas purifier column, (9) Getter furnace, (10) Argon gas, (11) Gas bubbling indicators, (12) Exhaust

Figure 3-5: Schematic diagram of the experimental set up for the horizontal furnace 


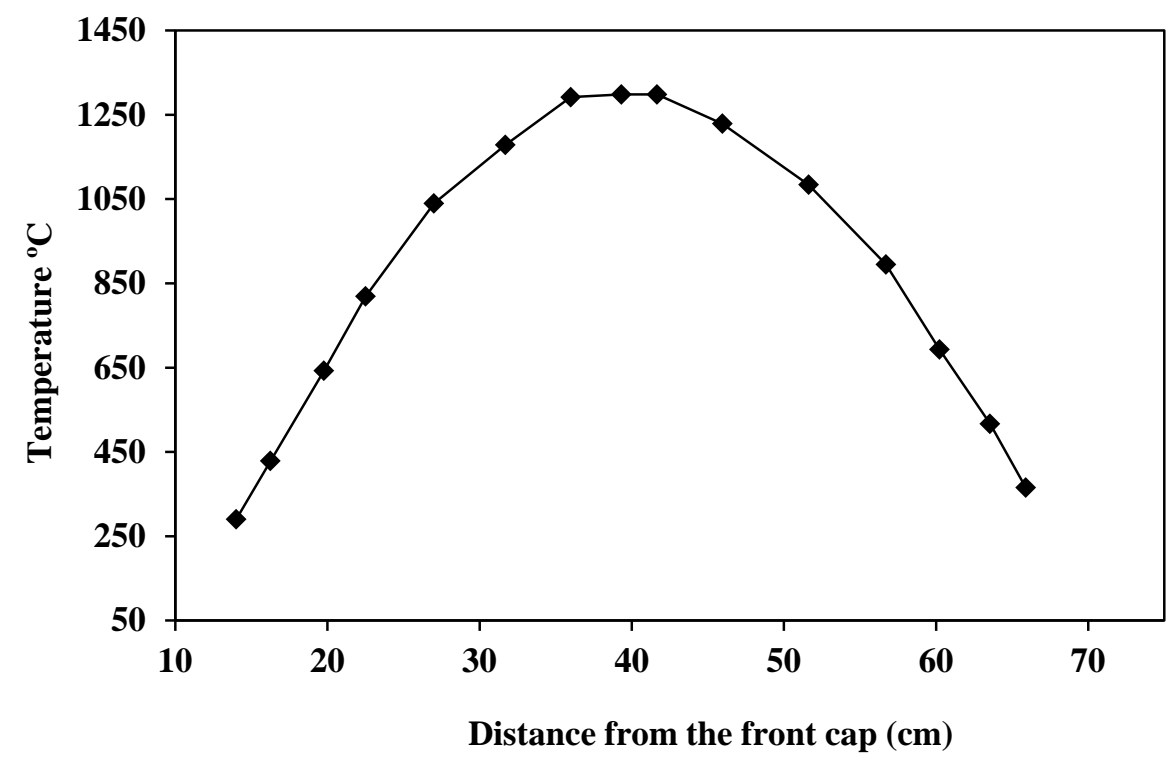

Figure 3-6: Temperature profile and hot zone of the horizontal tube furnace

\subsubsection{Experimental procedure}

A series of experiments were carried out to determine the required time to achieve equilibrium. According to the results, the holding time of $32 \mathrm{~h}$ at the target temperature was chosen in the subsequent experiments.

For preparation of each sample, flux components from Table 3-3 were weighed (10 g), mixed and pressed into a custom made ARMCO iron crucible (H: $35 \mathrm{~mm}$, OD: $30 \mathrm{~mm}$, ID: $27 \mathrm{~mm}$ ), Figure 3-7(a) together with $0.3 \mathrm{~g}$ of iron foil, Figure 3-7(b) and the crucible sealed with an iron lid which was made with the same material as the crucible. The crucible was then placed on the zirconia substrate and positioned horizontally in the tube on an alumina sample base. Afterward, the furnace was sealed and argon was purged at $250 \mathrm{~mL} / \mathrm{min}$ for $15 \mathrm{~min}$ to flush air out of the furnace. The argon flow was then decreased to $60 \mathrm{~mL} / \mathrm{min}$ and the furnace heated to the desired temperature and held for $32 \mathrm{~h}$ to reach equilibrium. After equilibrium, the iron crucible with its contents was taken out of the furnace and quenched in cold water.

After each experiment, the iron crucible was cut and the metal and slag phases were removed from the crucible. The metal part was carefully separated, Figure 3-7(c). The slag was cleaned and any metallic pieces removed using a magnet, then crushed and ground to a fine powder using 
a laboratory mill to a size of $110-200 \mu \mathrm{m}$. A few grams ( $4-6 \mathrm{~g})$ of slag powder were analyzed using XRF for high concentration components and 0.15 gram of slag was dissolved in aqua regia and analyzed by ICP for low concentration elements as explained earlier (Sec. 3.2.5). The iron foil, after cleaning in citric acid and an ultrasonic machine, was analyzed by ICP to determine the amount of phosphorus.

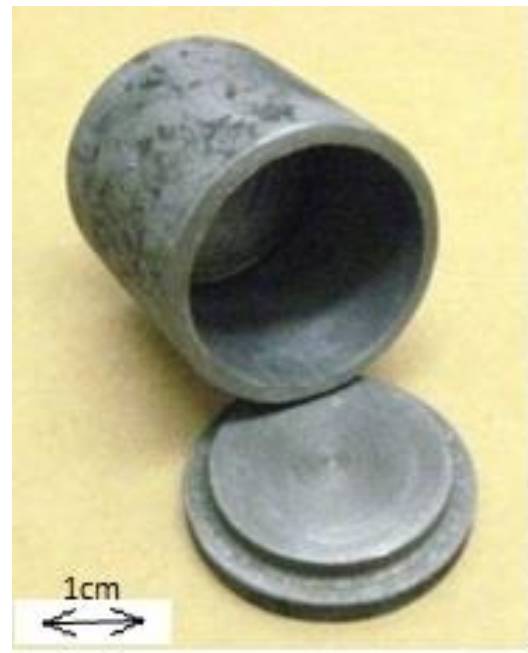

a

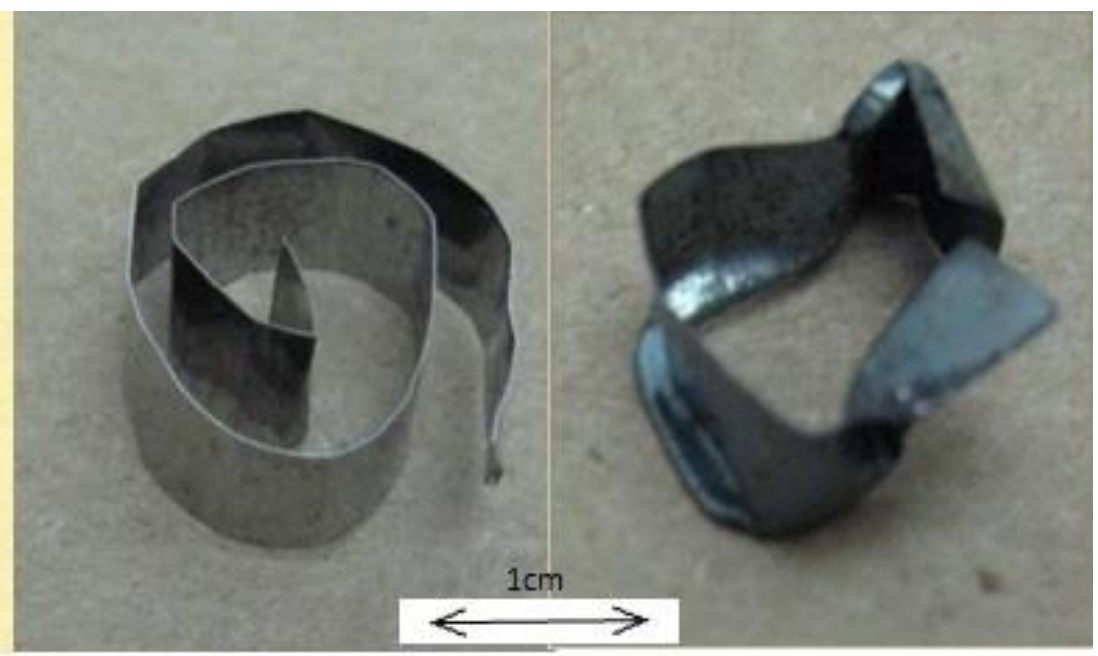

b
C

Figure 3-7: (a) ARMCO iron crucible; (b) Pure iron foil before experiment; (c) Iron foil after experiment

\subsection{Melting behavior experiments}

The study of the melting behavior of flux materials during the heating process is one of the most critical steps in the flux design. The physical and chemical properties of the flux determine its effectiveness in providing a cover and removing of inclusions. In the past, a few investigations have been done on the effect of chemical composition on the melting behavior of some fluxes [88-93]. However, there are no available data pertaining to the melting behavior of red mud based fluxes. Practically all the methods used to obtain the melting properties of fluxes rely on visual observation of the flux behavior during heating [94]. A custom made high temperature optical microscope system was assembled to measure the linear dimensional variation of flux compacts up to $1400^{\circ} \mathrm{C}$ according to the German Industrial Standard 51730 [95]. 


\subsubsection{Materials}

The raw materials used in the melting behavior experiments are shown in Appendix 2 (Table A2-4).

\subsubsection{Flux components}

The flux samples with different optical basicity ranging from 0.7 to 0.8 were prepared using a mixture of dried red mud and high purity reagent $\mathrm{CaO}, \mathrm{SiO}_{2}, \mathrm{Al}_{2} \mathrm{O}_{3}$, and $\mathrm{TiO}_{2}$ to obtain the compositions shown in Table 3-2. Fluxes RMF1 to RMF6 are meant to show the effect of lime content in the flux on its melting behavior. Fluxes RMF7 to RMF10, RMF11 to RMF14, and RMF15 to RMF18 were designed to examine the effects of alumina, titania, and silica respectively.

\subsubsection{Apparatus}

A schematic diagram of the experimental apparatus is shown in Figure 3-8. The equipment consists of two main parts: a horizontal tube furnace with $\mathrm{MoSi}_{2}$ heating elements and a 69.85 $\mathrm{mm}(\mathrm{OD}) \times 3 \mathrm{~mm}$ (Wall) alumina work tube (McDaniel Refractory Co.), and a Zeiss optical tube with CCD video camera which was controlled by Vision Gauge software. The temperature of the furnace was controlled by a B-type thermocouple (Pt30\% Rh - Pt/6\% Rh) and PID controller, and argon was passed through the heating tube at a flow rate of $60 \mathrm{~mL} / \mathrm{min}$. Accuracy of temperature measurement was checked using a separate R-type (Pt/Pt-13\% Rh) thermocouple placed close to the holder and a USB data acquisition recorded the temperature which was assumed to be the same as the sample.

The accuracy of the thermocouple was confirmed by measuring the temperature at the melting point of tin $\left(232^{\circ} \mathrm{C}\right)$ and copper $\left(1085^{\circ} \mathrm{C}\right)$ Table $3-4$.

Table 3-4: Validation of thermocouple accuracy

\begin{tabular}{|c|c|c|}
\hline Material & Measured melting point $\left({ }^{\circ} \mathrm{C}\right)$ & $\begin{array}{c}\text { Reference melting point }\left({ }^{\circ} \mathrm{C}\right) \\
{[96]}\end{array}$ \\
\hline Tin & 235 & 232 \\
\hline Copper & 1087 & 1085 \\
\hline
\end{tabular}




\subsubsection{Experimental procedure}

The sample, weighing approximately $17 \mathrm{~g}$, was pressed into a cylindrical pellet $(\mathrm{D}=15 \mathrm{~mm}$ and $\mathrm{H}=15 \mathrm{~mm}$ ) using a hydraulic press die. Before placing the sample compact into the furnace, temperature was raised to $1100{ }^{\circ} \mathrm{C}$ which is a minimum of $150{ }^{\circ} \mathrm{C}$ below the target temperature [95], at the rate of $4{ }^{\circ} \mathrm{C}$ per minute. The compact was then placed on a sample holder made of alumina and positioned into the heated tube furnace at $1100{ }^{\circ} \mathrm{C}$; the furnace glass cover was mounted and argon purge began. The temperature was then increased to the final temperature at the rate of $10{ }^{\circ} \mathrm{C}$ per minute. During heating, the dimensional variations of the sample were constantly recorded using the camera placed in front of a transparent window of the tube furnace. The characteristic temperatures of the sample were evaluated from optical images taken during heating according to German Industrial Standard 51730.

\subsubsection{Characteristic temperatures}

The following are defined according to the German Industrial Standard 51730 (Figure 3-9) [95].

1) Deformation temperature (DT): The temperature at which the outline of the sample starts to change.

2) Hemispherical temperature (HT): The temperature at which the specimen assumes hemispherical shape and is measured as the temperature at which the ratio of the final height $\left(\mathrm{H}_{\mathrm{h}}\right)$ to the initial height $\left(\mathrm{H}_{\mathrm{i}}\right)$ of the specimen is $\sim 0.6$.

3) Flowing temperature (FT): The temperature at which the ratio of the final height $\left(\mathrm{H}_{\mathrm{f}}\right)$ to the initial height $\left(\mathrm{H}_{\mathrm{i}}\right)$ of the specimen is $\sim 0.3$. The final height of the specimen is half of the height of the test piece at the hemisphere temperature 


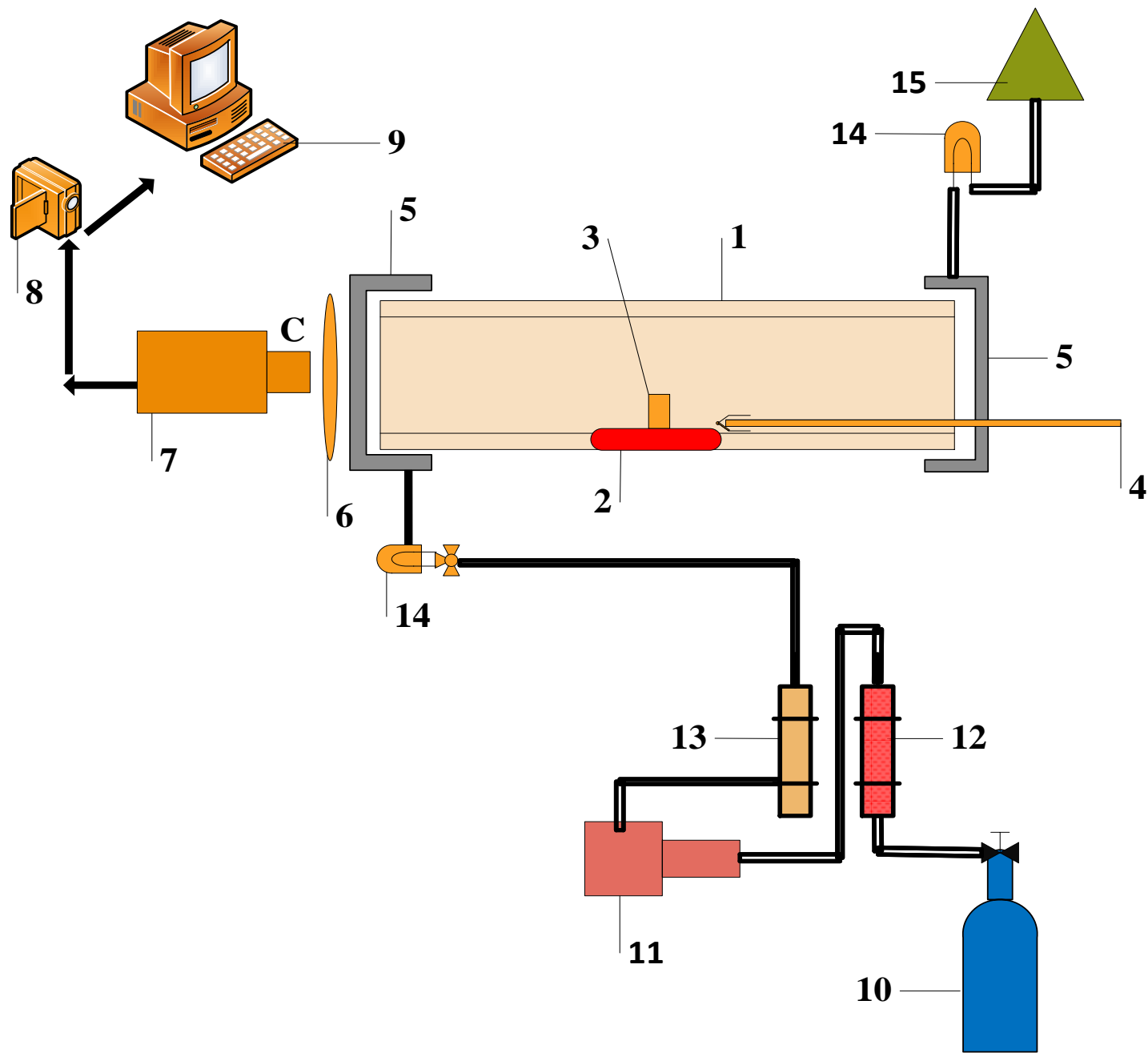

(1) Alumina tube, (2) Alumina holder, (3) Pellet sample, (4) Thermocouple, (5) Water cooled aluminum caps, (6) Quartz window, (7) Optical tube, (8) CCD camera, (9) Computer, (10) Argon gas, (11) Getter furnace, (12) Gas drying unit, (13) Gas purifier unit, (14) Gas bubbling indicator, (15) Exhaust

Figure 3-8: Schematic diagram of high temperature microscopy facility

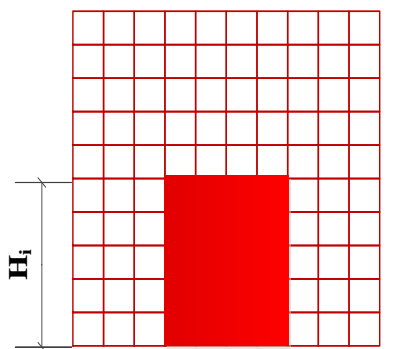

Initial shape

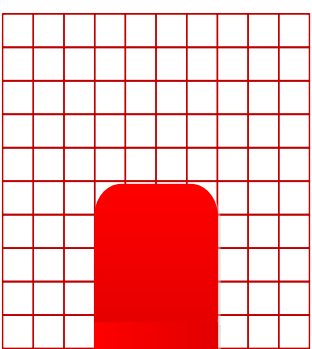

Softening

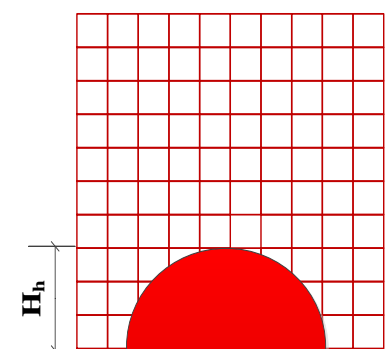

Hemisphere

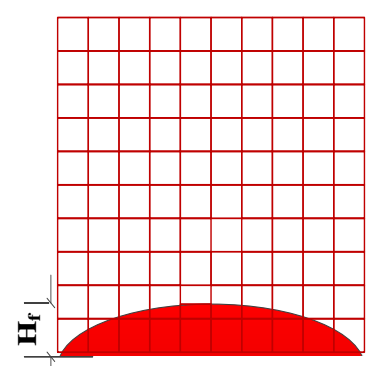

Flow

Figure 3-9: Definition of characteristic temperatures 


\section{Chapter 4}

\section{$4 \quad$ Results and Discussion}

This chapter presents the experimental results in four sections: red mud characterization in Section 4-1, equilibrium studies on the desulphurization and dephosphorization including the effect of composition and temperature on the sulphide capacity and phosphorus distribution in Sections 4-2 and 4-3 respectively, and melting behaviour of the synthetic fluxes and the effect of composition on characteristic temperatures in Section 4-4.

\subsection{Red mud characterization}

\subsubsection{Phase identification and quantitative analysis}

The X-ray diffraction pattern of the dried red mud sample that was used in the current study is given in Figure 4-1. The main crystalline constituents are iron oxide as hematite, aluminum hydroxide, titanium oxide, calcium titanate, and sodium aluminum silicate. The evaluated phases of RM in this study agree with those phases reported in the literature[97, 98].

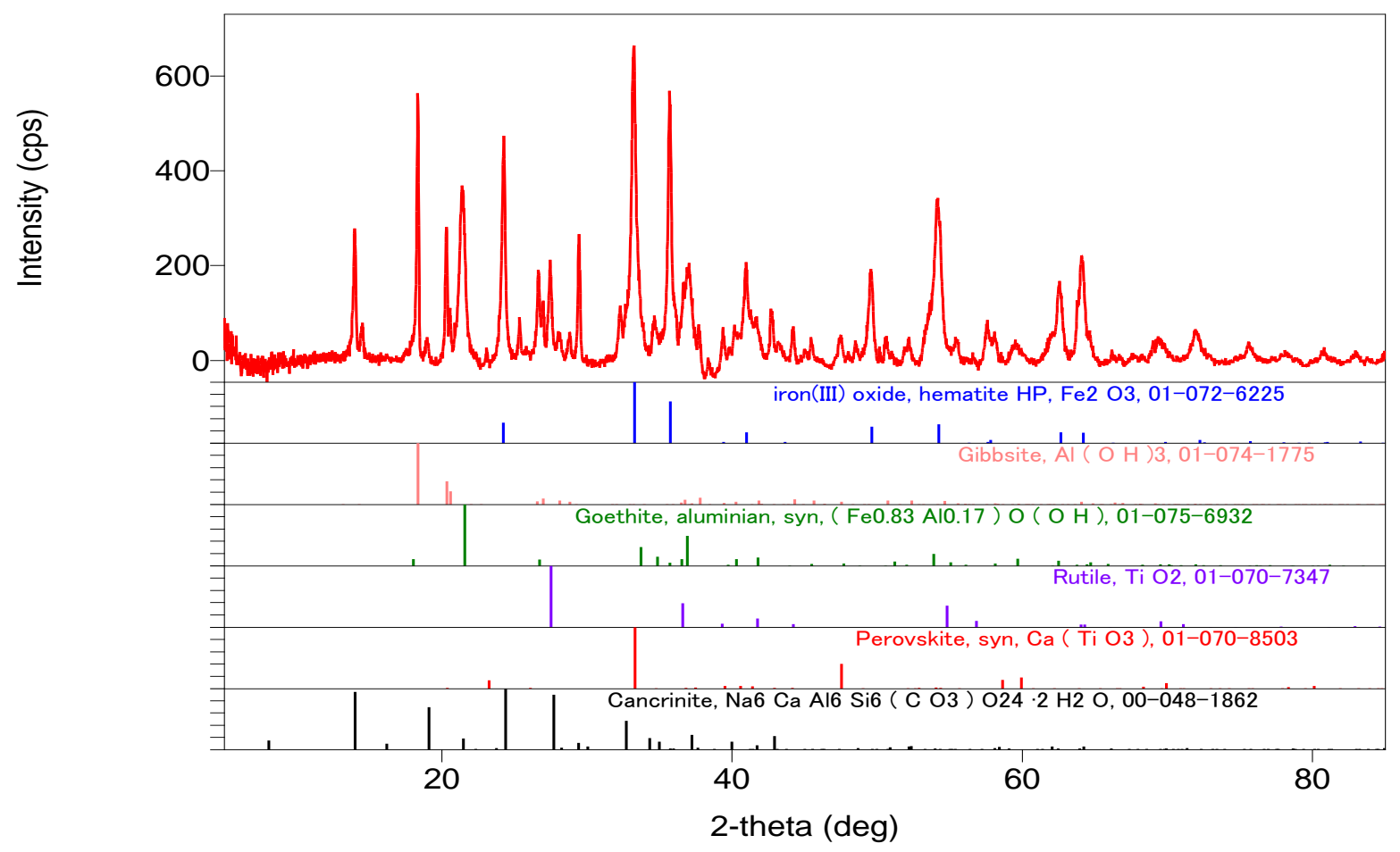

Figure 4-1: XRD pattern of red mud (RM) 
The chemical composition of the red mud determined by X-ray fluorescence (XRF) analysis is given in Table 4-1. It confirms that the chemical composition of this material is in accord with reported compositions of red mud from different sources, Table 4-2. The differences are because of the quality of bauxite ore and operational parameters of the upgrading process such as pressure, temperature and the additives used.

Table 4-1: Quantitative analysis of the red mud

\begin{tabular}{cc|cc}
\hline Compounds & wt $\%$ & Compounds & wt $\%$ \\
\hline $\mathrm{Al} 2 \mathrm{O} 3$ & 19.60 & $\mathrm{Fe} 2 \mathrm{O} 3$ & 45.12 \\
$\mathrm{SiO} 2$ & 10.95 & $\mathrm{TiO} 2$ & 7.07 \\
$\mathrm{Na} 2 \mathrm{O}$ & 9.37 & $\mathrm{CaO}$ & 3.9 \\
$\mathrm{P}_{2} \mathrm{O}_{5}$ & 0.18 & $\mathrm{SO}_{3}$ & 0.25 \\
Other & 3.5 & - & \\
\hline
\end{tabular}

Table 4-2: Major chemical composition of red muds from different locations (wt\%) [98]

\begin{tabular}{cccccccccc}
\hline & $\begin{array}{c}\text { Current } \\
\text { study }\end{array}$ & China & Australia & Jamaica & Spain & Hungary & Germany & Italy & IAI* \\
\hline $\mathrm{Fe}_{2} \mathrm{O}_{3}$ & 45.12 & 36.22 & 34.05 & 51.50 & 47.85 & 37.08 & 43.94 & 46.12 & $30-60$ \\
$\mathrm{Al}_{2} \mathrm{O}_{3}$ & 19.60 & 20.85 & 25.45 & 15 & 20.20 & 13.64 & 14.08 & 15.34 & $10-20$ \\
$\mathrm{CaO}$ & 3.90 & 3.04 & 3.69 & 7 & 6.22 & 9.37 & 4.36 & 4.39 & $2-8$ \\
$\mathrm{TiO}_{2}$ & 7.07 & 6.26 & 4.90 & 6.70 & 9.91 & 3.50 & 7.27 & 8.82 & $\begin{array}{c}\text { Trace- } \\
10\end{array}$ \\
$\mathrm{Na}_{2} \mathrm{O}$ & 9.37 & 12.7 & 2.74 & 6.97 & 8.40 & 8.76 & 8.15 & 6.36 & $2-10$ \\
$\mathrm{SiO}_{2}$ & 10.95 & 15.89 & 17.06 & 1.70 & 7.5 & 12.41 & 10.34 & 8.32 & $3-50$ \\
$\mathrm{P}_{2} \mathrm{O}_{5}$ & 0.18 & N/A & N/A & N/A & 0.46 & 0.08 & 0.11 & 0.20 & N/A \\
$\mathrm{SO}_{3}$ & 0.25 & N/A & N/A & N/A & 0.15 & 1.37 & 0.57 & 0.3 & N/A \\
\hline
\end{tabular}

* International Aluminum Institute 


\subsubsection{TGA analysis of red mud}

Thermal analysis was performed in a Netzsch STA 449 F3 simultaneous thermal analyzer to characterize red mud samples with respect to weight change between room temperature and $1400{ }^{\circ} \mathrm{C}$. The results of the thermal analysis of red mud sample at the heating rate of $10 \mathrm{C} \cdot \mathrm{min}^{-1}$ under argon atmosphere (flow $=20 \mathrm{~mL} / \mathrm{min}$ ) are plotted in Figure 4-2.

The TGA diagram shows a continuous weight loss distributed in the range of $25^{\circ} \mathrm{C}-1400{ }^{\circ} \mathrm{C}$ with a total mass loss of $15.08 \%$ up to $1400^{\circ} \mathrm{C}$ and a significant weight loss before $330{ }^{\circ} \mathrm{C}$. The first derivative of mass change with temperature (DTG) and Differential Scanning Calorimetry (DSC) are plotted on the same figure to show the critical temperatures more clearly. There is no sharp mass or phase change above $900{ }^{\circ} \mathrm{C}$.

Three separate peaks are evident from DTG graph: at 280,315 and $685^{\circ} \mathrm{C}$. The first and major mass loss $(5.95 \%)$ occurs around $280{ }^{\circ} \mathrm{C}$. This can be related to water evaporation, gibbsite decomposition and formation of $\gamma-\mathrm{Al}_{2} \mathrm{O}_{3}$. The following reaction is suggested by Atasoy [99] and Mehta et al. [100] at this temperature:

$$
2 \mathrm{Al}(\mathrm{OH})_{3} \rightarrow \gamma-\mathrm{Al}_{2} \mathrm{O}_{3}+3 \mathrm{H}_{2} \mathrm{O}
$$

A second mass loss $(3.03 \%)$ around $315^{\circ} \mathrm{C}$ may be associated with the decomposition of goethite into hematite, according to the following reaction:

$$
2 \mathrm{FeO}(\mathrm{OH}) \rightarrow \mathrm{Fe}_{2} \mathrm{O}_{3}+\mathrm{H}_{2} \mathrm{O} \quad \text { goethite } \rightarrow \text { hematite }+ \text { water }
$$

The mass loss at $685^{\circ} \mathrm{C}$ can be attributed to the decomposition of calcite $[100,101]$.

Considering DSC curve in Figure 4-2, one can identify different endothermic peaks at 280, 315, 685 and $1220{ }^{\circ} \mathrm{C}$. It is likely that the first two endothermic peaks between $280{ }^{\circ} \mathrm{C}$ and $312{ }^{\circ} \mathrm{C}$ can be correlated to the gibbsite and goethite dehydroxylation. The difference in their decomposition temperature is related to the difference in the dehydroxylation temperature of $\mathrm{Al}-\mathrm{OH}$ and $\mathrm{Fe}-\mathrm{OH}$ 
groups [98]. The endothermic peak observed at $685^{\circ} \mathrm{C}$ is likely due to decomposition of calcite. Similar experimental observations have been reported by Alp and Coral [102]. They described an endothermic peak for this reaction that starts at about $680^{\circ} \mathrm{C}$ and ends at $776{ }^{\circ} \mathrm{C}$.

The endothermic peak at $1220^{\circ} \mathrm{C}$ on the DSC curve which is accompanied by a small mass loss on the DTG curve can be attributed to decomposition of sodium oxide that results in loss of $\mathrm{Na}$ vapor and $\mathrm{O}_{2}$ to the gas. Since sodium is primarily tied in the aluminosilicates, the extent of this reaction is limited.

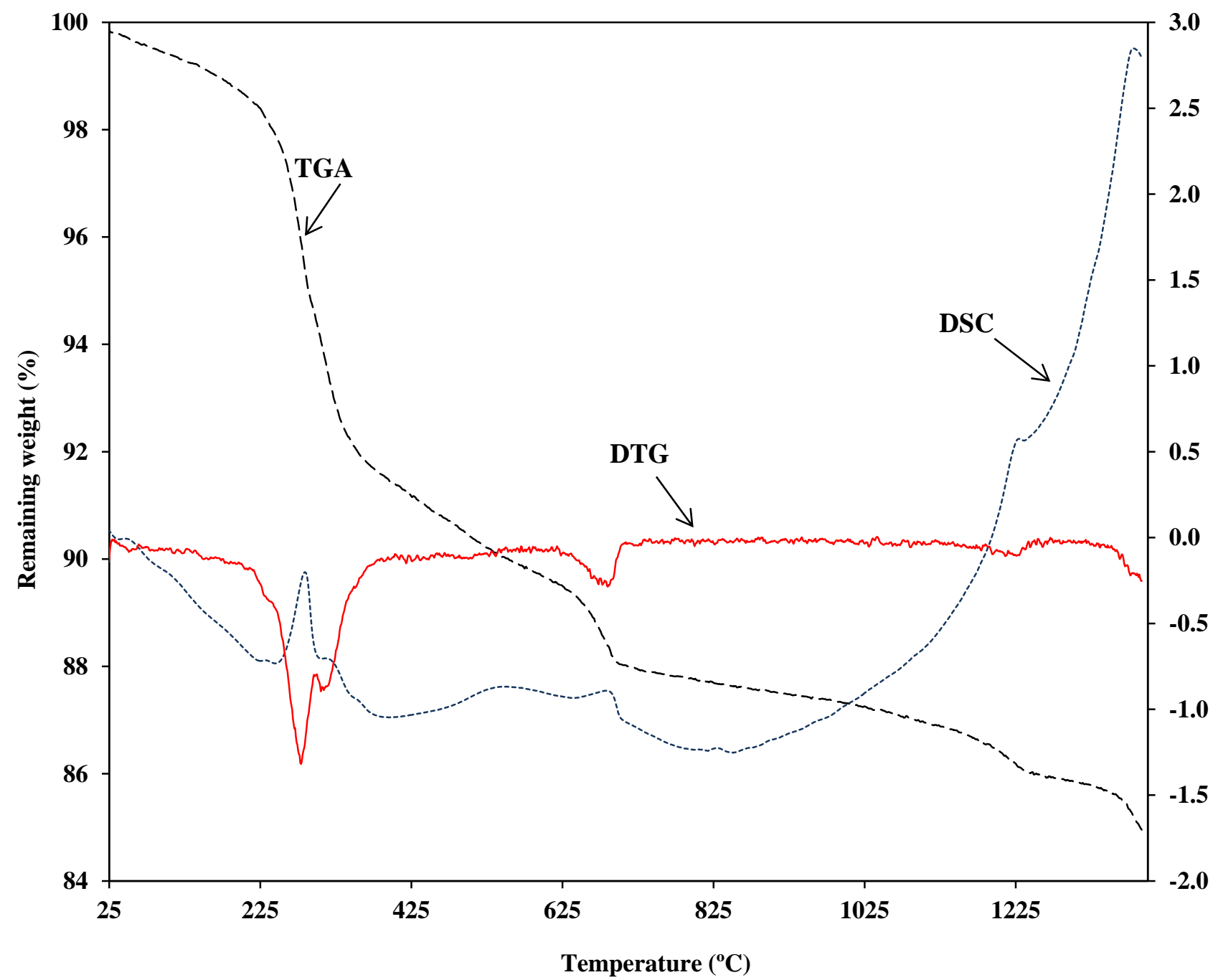

Figure 4-2: TGA, DSC and DTG curves obtained from thermal analysis of red mud

After thermal analysis, XRD analysis was conducted on the products to examine the effect on a change in mineralogical make of the red mud. Figure 4-3 shows the XRD pattern, indicating that 
the main phases are hematite, nepheline, perovskite, dicalcium aluminum and gehlenite. It appears that the thermal treatment has resulted in formation of multi-component oxides.

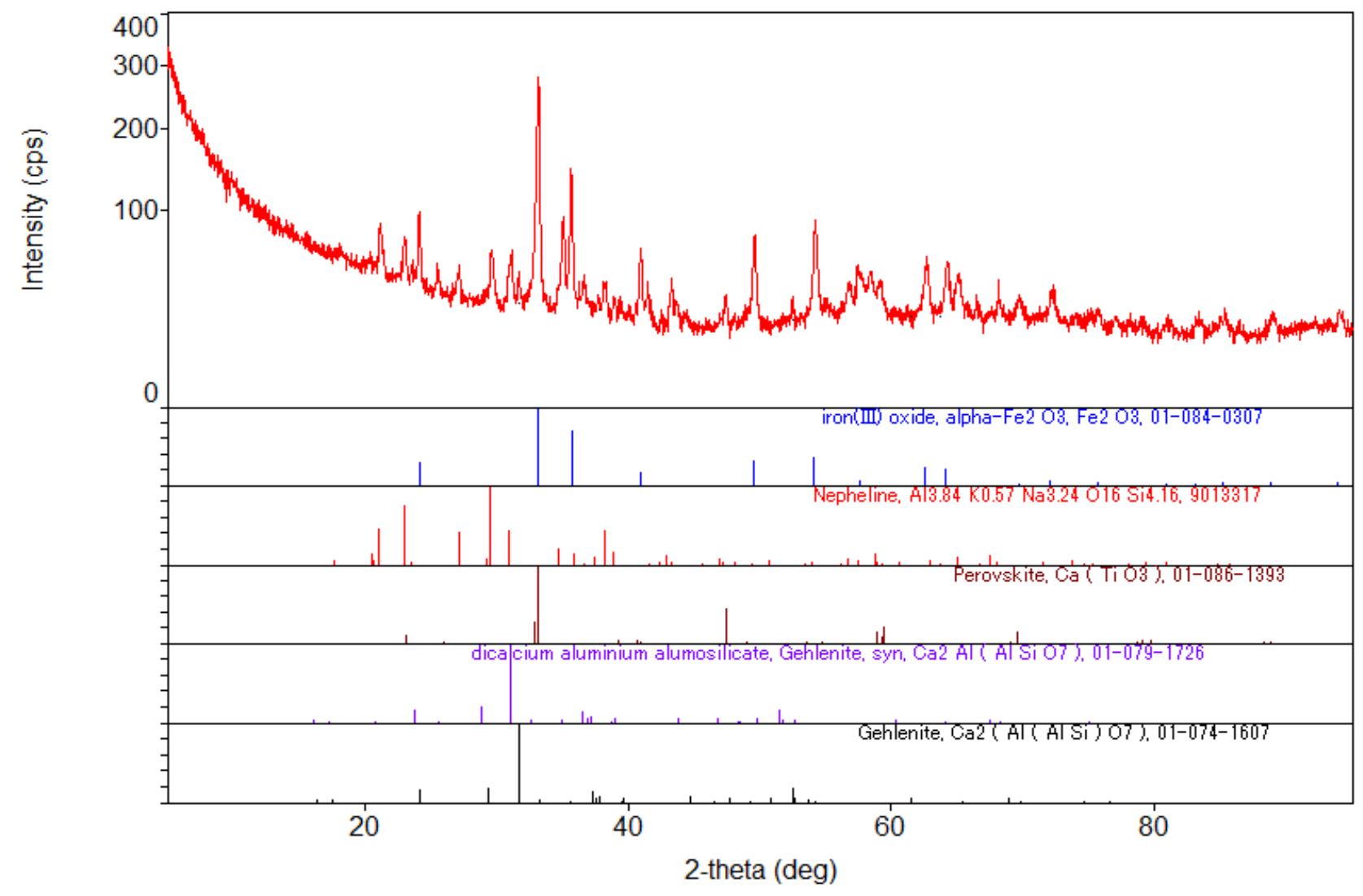

Figure 4-3: XRD pattern of red mud after thermal treatment at $1400{ }^{\circ} \mathrm{C}$

\subsubsection{Particle size analysis}

The results of particle size analysis are shown in Figure 4-4. As seen, the range is relatively wide, from 0.3 to $200 \mu \mathrm{m}$. The cumulative particle size distribution in Figure $4-4$ shows that approximately $90 \mathrm{vol} \%\left(\mathrm{D}_{90}\right)$ of the dried red mud is $\leq 55 \mu \mathrm{m}, 50 \mathrm{vol} \%\left(\mathrm{D}_{50}\right) \leq 6.75 \mu \mathrm{m}$ and 10 vol \% $\left(\mathrm{D}_{10}\right)$ is $\leq 1.5 \mu \mathrm{m}$. These are in agreement with other studies. Roach [103] and Grafe [1] for example have reported that the particle size of bauxite residue is typically in the range of 100 $\mathrm{nm}$ to $200 \mu \mathrm{m}$ while their measurements on some samples yielded 2-100 $\mu \mathrm{m}$. The scanning electron microscopy (SEM) image of red mud is shown in Appendix 3 (Figure A3-1). 


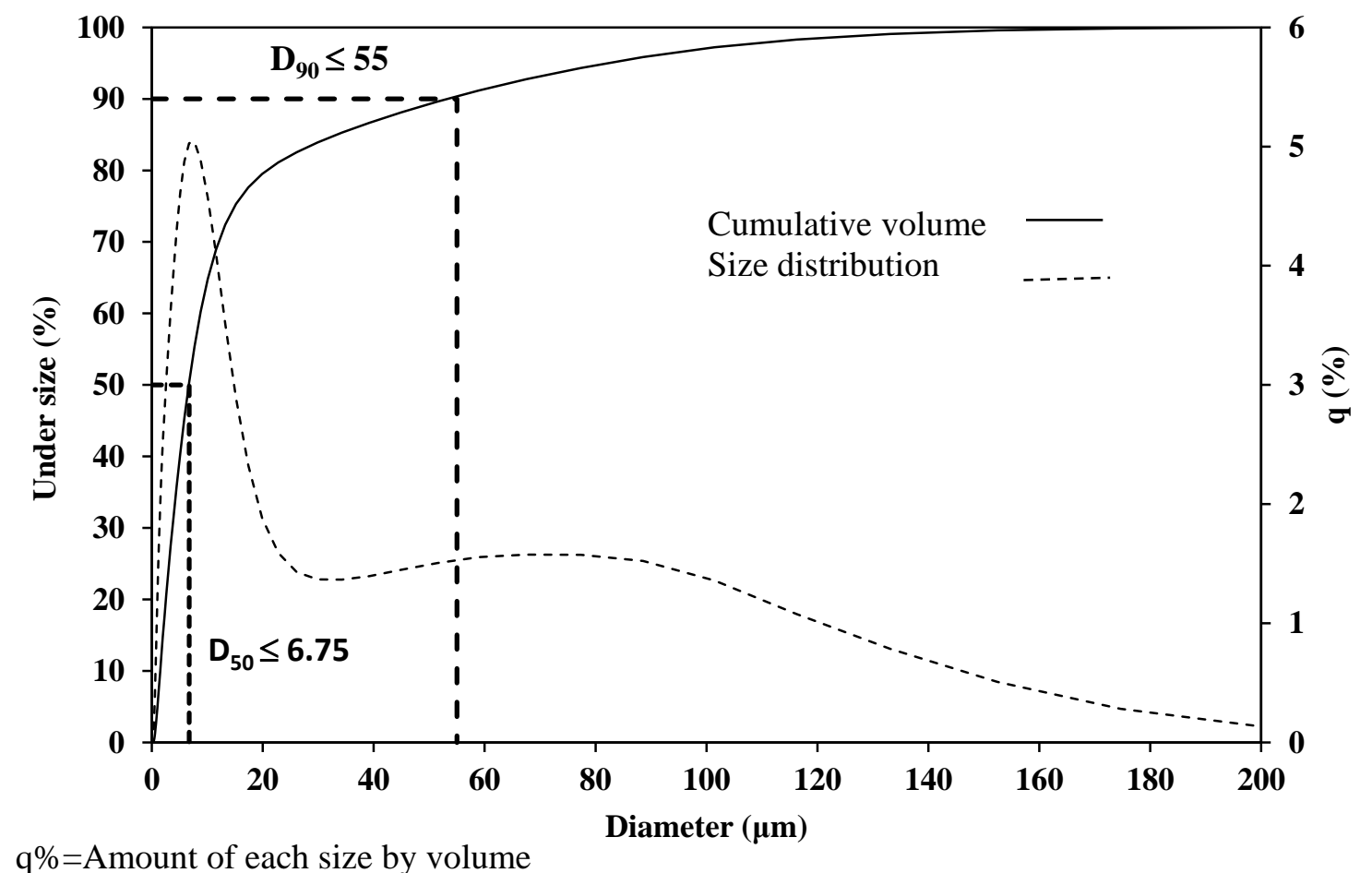

Figure 4-4: Particle size analysis of the red mud

\subsection{Desulphurization studies}

In the present work the effect of different additives on the sulphide capacity of the red mud based fluxes was studied using flux-metal equilibrium technique in the temperature range of 1300$1400{ }^{\circ} \mathrm{C}$ using graphite crucibles under reducing atmosphere. Table 3-2 presents the chemical composition of the initial fluxes, which were prepared using the dried red mud from Bayer process and reagent grade $\mathrm{CaO}, \mathrm{Al}_{2} \mathrm{O}_{3}, \mathrm{TiO}_{2}$ and $\mathrm{SiO}_{2}$ as additives.

\subsubsection{Sulphide capacity measurement between red mud based fluxes and hot metal}

The sulphide capacity for each experiment was calculated in terms of the sulphur distribution ratio, $\mathrm{L}_{\mathrm{S}}=\frac{(\mathrm{wt} \% \mathrm{~S})}{[\mathrm{wt} \% \mathrm{~S}]}$, by considering the change of Gibb's free energy for the dissolution of gaseous sulphur into liquid iron as follows [44]:

$\log C_{S}=\log L_{S}+\frac{1}{2} \log P_{O_{2}}-\log f_{S}+\frac{7055}{T}-1.224$ 
where $C_{S}$ is the sulphide capacity of slag, $f_{S}$ is the activity coefficient of sulphur in liquid iron based on $1 \mathrm{wt} \%$ standard sate, $P_{\mathrm{O}_{2}}$ is the partial pressure of $\mathrm{O}_{2}$, and $\mathrm{T}$ is the absolute temperature of the system. Equation 4-3 indicates that for effective desulphurization, slag must have a large sulphide capacity, activity coefficient of sulphur in liquid iron needs to be high, also high temperature and low oxygen partial pressure, i.e. reducing conditions are desired.

The oxygen partial pressure was calculated based on the equilibrium between the applied atmosphere $(\mathrm{CO}=1 \mathrm{~atm})$ and the graphite crucible, according to:

$\mathrm{C}(\mathrm{gr})+\frac{1}{2} \mathrm{O}_{2}(\mathrm{~g})=\mathrm{CO}(\mathrm{g})$

$\Delta \mathrm{G}^{\circ}=-114391-85.77 \mathrm{~T}(\mathrm{~J} / \mathrm{mol})$

4-5

$\frac{1}{2} \log \mathrm{PO}_{2}=\log \mathrm{a}_{\mathrm{C}}+\log \mathrm{P}_{\mathrm{CO}}-\left(\frac{5976}{\mathrm{~T}}+4.48\right)$

4-6

where in the present study: $\mathrm{a}_{\mathrm{C}}=1, \mathrm{P}_{\mathrm{CO}}=1 \mathrm{~atm}$

Table 4-3: Partial pressure of oxygen at different temperatures

\begin{tabular}{cll}
\hline Temperature, ${ }^{\circ} \mathrm{C}$ & $\log \mathrm{P}_{\mathrm{O} 2}$ & $\mathrm{P}_{\mathrm{O} 2}(\mathrm{~atm})$. \\
\hline 1300 & -16.56 & $2.77 \times 10^{-17}$ \\
1350 & -16.32 & $4.74 \times 10^{-17}$ \\
1400 & -16.10 & $7.87 \times 10^{-17}$ \\
\hline
\end{tabular}

The value of $f_{S}$, sulphur activity coefficient in liquid iron was calculated using the interaction coefficients at $1600{ }^{\circ} \mathrm{C}$ as given by Sigworth and Elliot [104] $\left(\mathrm{e}_{\mathrm{S}}^{\mathrm{C}}=0.11, \mathrm{e}_{\mathrm{S}}^{\mathrm{O}}=-0.27\right.$, $\mathrm{e}_{\mathrm{S}}^{\mathrm{S}}=$ -0.028). Since $\mathrm{P}_{\mathrm{O}_{2}}$ is small, only $\mathrm{e}_{\mathrm{S}}^{\mathrm{C}}$ and $\mathrm{e}_{\mathrm{S}}^{\mathrm{S}}$ are considered.

$\log _{S}=e_{S}^{C} \cdot w t \% C+e_{S}^{S} \cdot w t \% S$

$\log _{\mathrm{S}}(1873 \mathrm{~K})=0.11 \times \mathrm{wt} \% \mathrm{C}-0.028 \times \mathrm{wt} \% \mathrm{~S}$

The activity coefficient is extrapolated from 1873 to $1473 \mathrm{~K}$ assuming it is inversely proportional to temperature [56]. 
$\log _{\mathrm{S}(\mathrm{T})}=\log _{\mathrm{S}(1873 \mathrm{~K})} \times\left(\frac{1873}{\mathrm{~T}}\right)$

\subsubsection{Optical basicity}

The optical basicity of a multi component slag with given composition was calculated using the following relationship [41] in which $\mathrm{X}$ is the equivalent cation fraction calculated from Equation 4-11 [41] and $\Lambda$ is the optical basicity value of the slag component, taken from the recommended values provided in Table 4-4.

$\Lambda=\mathrm{X}_{A} \Lambda_{\mathrm{A}}+\mathrm{X}_{B} \Lambda_{\mathrm{B}}+\cdots$

$\mathrm{X}=\frac{x_{i} n_{i}}{\sum x_{i} n_{i}}$

In Eq. 4-11, $x_{i}$ and $n_{i}$ are the mole fraction and number of oxygen atoms in the oxide molecule $i$ respectively.

Table 4-4: Optical basicity values used in the calculations [41]

\begin{tabular}{cc}
\hline Compound & Optical basicity value, $\Lambda$ \\
\hline $\mathrm{CaO}$ & 1 \\
$\mathrm{Al}_{2} \mathrm{O}_{3}$ & 0.65 \\
$\mathrm{SiO}_{2}$ & 0.48 \\
$\mathrm{SO}_{3}$ & 0.33 \\
$\mathrm{FeO}$ & 0.93 \\
$\mathrm{TiO}_{2}$ & 0.65 \\
$\mathrm{Na}_{2} \mathrm{O}$ & 1.15 \\
$\mathrm{P}_{2} \mathrm{O}_{5}$ & 0.4 \\
\hline
\end{tabular}

The calculated values for the flux basicity, defined as $\mathrm{B}=\% \mathrm{CaO} / \mathrm{SiO}_{2}$ or optical basicity are listed in Table 3-2. 


\subsubsection{Equilibrium time}

Preliminary experiments were performed to determine the time required to reach equilibrium. Ranges of holding time from 5 to 35 hours were examined at $1350{ }^{\circ} \mathrm{C}$ (Table 4-6). Figure 4-5 shows the variation with time of sulphur partition ratio for flux composition RMF1, RMF2 and RMF4. As seen, the sulphur partition ratio reaches a steady state value, here defined as equilibrium concentration, after $\sim 25$ hours Therefore, for subsequent experiments the holding time was set to $30 \mathrm{hr}$ to ensure equilibrium is reached under various conditions.

Table 4-5: Initial chemical compositions of red mud based fluxes used in the experiments

\begin{tabular}{|c|c|c|c|c|c|c|c|c|}
\hline \multirow{2}{*}{$\begin{array}{c}\text { Flux } \\
\text { No. }\end{array}$} & \multicolumn{6}{|c|}{ Composition wt $\%$} & \multirow{2}{*}{$\begin{array}{c}\text { Basicity } \\
\text { (B) }\end{array}$} & \multirow{2}{*}{$\begin{array}{l}\text { Optical basicity } \\
(\Lambda)\end{array}$} \\
\hline & $\mathrm{Fe}_{2} \mathrm{O}_{3}$ & $\mathrm{Al}_{2} \mathrm{O}_{3}$ & $\mathrm{TiO}_{2}$ & $\mathrm{CaO}$ & $\mathrm{Na}_{2} \mathrm{O}$ & $\mathrm{SiO}_{2}$ & & \\
\hline RMF1 & 46.5 & 20 & 8 & 4 & 10 & 11.5 & 0.34 & 0.72 \\
\hline RMF2 & 41.9 & 18.0 & 7.2 & 13.6 & 9.0 & 10.4 & 1.3 & 0.73 \\
\hline RMF3 & 37.2 & 16.0 & 6.4 & 23.2 & 8.0 & 9.2 & 2.5 & 0.75 \\
\hline RMF4 & 32.6 & 14.0 & 5.6 & 32.8 & 7.0 & 8.1 & 4.1 & 0.76 \\
\hline RMF5 & 27.9 & 12.0 & 4.8 & 42.4 & 6.0 & 6.9 & 6.1 & 0.78 \\
\hline RMF6 & 23.3 & 10.0 & 4.0 & 52.0 & 5.0 & 5.8 & 9.0 & 0.80 \\
\hline RMF7 & 29.6 & 21.8 & 5.1 & 29.8 & 6.4 & 7.3 & 4.1 & 0.74 \\
\hline RMF8 & 28.3 & 25.2 & 4.9 & 28.5 & 6.1 & 7.0 & 4.1 & 0.74 \\
\hline RMF9 & 27.1 & 28.3 & 4.7 & 27.3 & 5.8 & 6.7 & 4.1 & 0.73 \\
\hline RMF10 & 26.0 & 31.2 & 4.5 & 26.2 & 5.6 & 6.4 & 4.1 & 0.72 \\
\hline RMF11 & 31.0 & 13.3 & 10.1 & 31.2 & 6.7 & 7.7 & 4.1 & 0.76 \\
\hline RMF12 & 30.1 & 13.0 & 12.6 & 30.4 & 6.5 & 7.5 & 4.1 & 0.76 \\
\hline RMF13 & 29.1 & 12.5 & 15.7 & 29.3 & 6.3 & 7.2 & 4.1 & 0.76 \\
\hline RMF14 & 28.3 & 12.2 & 17.9 & 28.5 & 6.1 & 7.0 & 4.1 & 0.76 \\
\hline RMF15 & 29.6 & 12.7 & 5.1 & 29.8 & 6.4 & 16.4 & 1.8 & 0.74 \\
\hline RMF16 & 28.3 & 12.2 & 4.9 & 28.5 & 6.1 & 20.0 & 1.4 & 0.73 \\
\hline RMF17 & 27.1 & 11.7 & 4.7 & 27.3 & 5.8 & 23.4 & 1.2 & 0.72 \\
\hline RMF18 & 26.0 & 11.2 & 4.5 & 26.2 & 5.6 & 26.4 & 1.0 & 0.70 \\
\hline
\end{tabular}




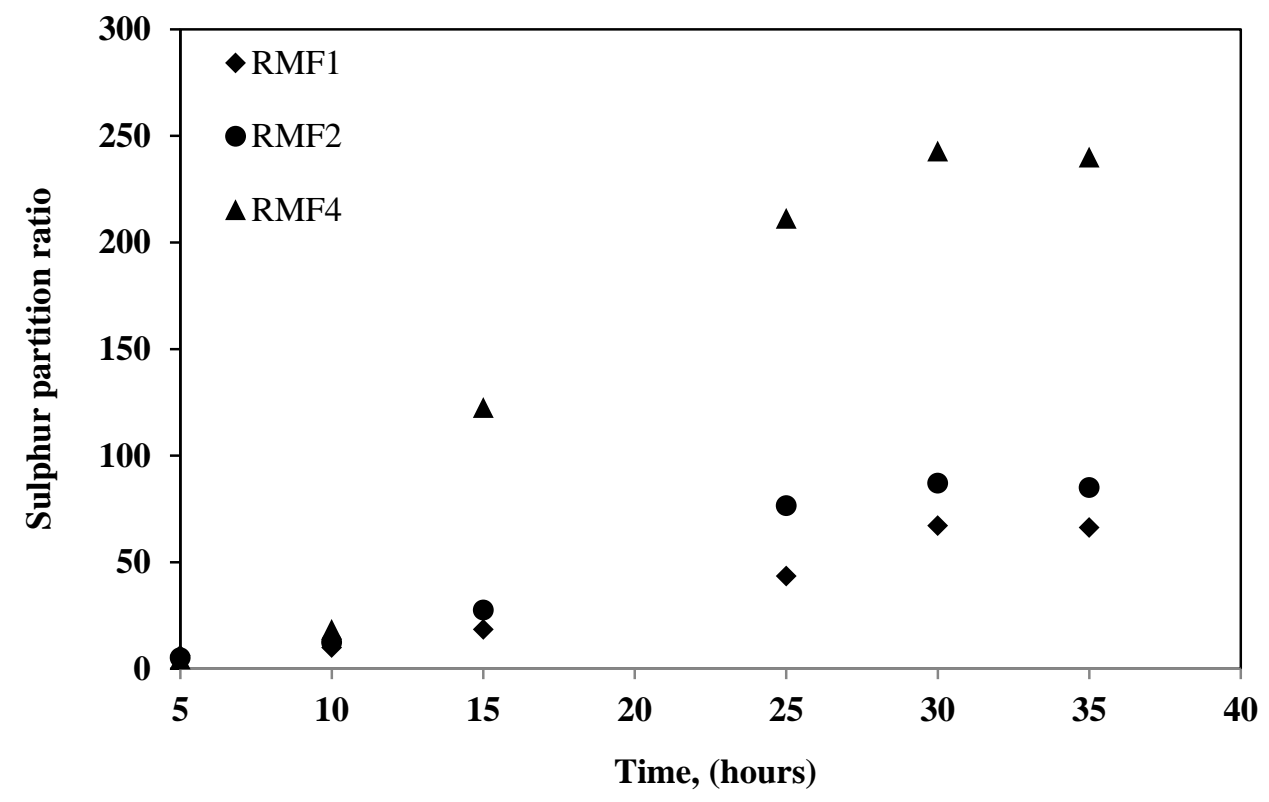

Figure 4-5: Variation of sulphur partition ratio with time at $1350{ }^{\circ} \mathrm{C}$

\subsubsection{Desulphurization results}

Table 4-7 presents the composition of metal and flux after equilibrium, along with the calculated sulphide capacity and optical basicity in the temperature range of $1300-1400{ }^{\circ} \mathrm{C}$. The flux composition is comparable with the original blend, except the $\mathrm{Na}_{2} \mathrm{O}$ content that has dropped significantly. In addition, iron oxide in the flux was reduced to metal with the carbon of hot metal and graphite crucible. 
Table 4-6: Results of the equilibrium time study

\begin{tabular}{|c|c|c|c|c|}
\hline Flux No. & Time (h) & {$[\mathrm{S}], \mathrm{wt} . \%$} & (S), wt.\% & $\mathrm{L}_{\mathrm{s}}$ \\
\hline RMF1 & 5 & 0.12 & 0.754 & 6.28 \\
\hline $\mathrm{RMF} 1$ & 10 & 0.09 & 0.894 & 9.93 \\
\hline RMF1 & 15 & 0.077 & 1.421 & 18.45 \\
\hline RMF1 & 25 & 0.035 & 1.522 & 43.49 \\
\hline RMF1 & 30 & 0.0225 & 1.51 & 67.11 \\
\hline RMF1 & 35 & 0.0225 & 1.49 & 66.22 \\
\hline RMF2 & 5 & 0.14 & 0.721 & 5.15 \\
\hline RMF2 & 10 & 0.077 & 0.9555 & 12.41 \\
\hline RMF2 & 15 & 0.0525 & 1.4455 & 27.53 \\
\hline RMF2 & 25 & 0.021 & 1.606 & 76.48 \\
\hline RMF2 & 30 & 0.02 & 1.742 & 87 \\
\hline RMF2 & 35 & 0.021 & 1.785 & 85 \\
\hline RMF4 & 5 & 0.15 & 0.688 & 4.59 \\
\hline RMF4 & 10 & 0.055 & 1.017 & 18.49 \\
\hline RMF4 & 15 & 0.012 & 1.47 & 122 \\
\hline RMF4 & 25 & 0.008 & 1.69 & 211 \\
\hline RMF4 & 30 & 0.007 & 1.7 & 242 \\
\hline RMF4 & 35 & 0.007 & 1.68 & 240 \\
\hline
\end{tabular}


Table 4-7- Experimental results of sulphur equilibrium between flux and metal

\begin{tabular}{|c|c|c|c|c|c|c|c|c|c|c|c|c|}
\hline \multirow{2}{*}{ Flux No. } & \multirow{2}{*}{ Temperature $\left({ }^{\circ} \mathrm{C}\right)$} & \multicolumn{7}{|c|}{ Flux compositions in mole fraction after equilibrium } & \multicolumn{2}{|c|}{ Metal phase, wt $\%$} & \multirow{2}{*}{$\log \mathrm{Cs}$} & \multirow{2}{*}{ Optical basicity } \\
\hline & & $\mathrm{CaO}$ & $\mathrm{Al}_{2} \mathrm{O}_{3}$ & $\mathrm{SiO}_{2}$ & $\mathrm{FeO}$ & $\mathrm{TiO}_{2}$ & $\mathrm{Na}_{2} \mathrm{O}$ & $\mathrm{S}$ & $\mathrm{S}$ & $\mathrm{C}$ & & \\
\hline RMF1 & 1300 & 0.139 & 0.323 & 0.286 & 0.055 & 0.160 & 0.029 & 0.009 & 0.121 & 4.61 & -4.72 & 0.62 \\
\hline RMF2 & 1300 & 0.367 & 0.239 & 0.204 & 0.055 & 0.102 & 0.024 & 0.009 & 0.113 & 4.90 & -4.65 & 0.68 \\
\hline RMF3 & 1300 & 0.535 & 0.175 & 0.151 & 0.039 & 0.067 & 0.020 & 0.014 & 0.097 & 4.20 & -4.30 & 0.73 \\
\hline RMF4 & 1300 & 0.621 & 0.140 & 0.113 & 0.045 & 0.052 & 0.016 & 0.014 & 0.034 & 4.98 & -3.90 & 0.77 \\
\hline RMF5 & 1300 & 0.682 & 0.105 & 0.103 & 0.046 & 0.049 & 0.0 & 0.014 & 0.029 & 4.90 & -3.85 & 0.79 \\
\hline RMF6 & 1300 & 0.765 & 0.065 & 0.076 & 0.050 & 0.031 & 0.0 & 0.013 & 0.032 & 4.70 & -3.88 & 0.84 \\
\hline RMF7 & 1300 & 0.599 & 0.206 & 0.093 & 0.049 & 0.044 & 0.016 & 0.009 & 0.027 & 4.62 & -3.99 & 0.75 \\
\hline RMF8 & 1300 & 0.582 & 0.228 & 0.087 & 0.053 & 0.042 & 0.014 & 0.010 & 0.034 & 4.77 & -4.08 & 0.74 \\
\hline RMF9 & 1300 & 0.544 & 0.245 & 0.088 & 0.061 & 0.039 & 0.016 & 0.008 & 0.062 & 4.78 & -4.41 & 0.74 \\
\hline RMF10 & 1300 & 0.544 & 0.274 & 0.078 & 0.049 & 0.038 & 0.011 & 0.006 & 0.068 & 4.76 & -4.59 & 0.74 \\
\hline RMF11 & 1300 & 0.594 & 0.141 & 0.109 & 0.036 & 0.097 & 0.014 & 0.007 & 0.015 & 5.65 & -3.90 & 0.76 \\
\hline RMF12 & 1300 & 0.573 & 0.128 & 0.107 & 0.048 & 0.122 & 0.015 & 0.007 & 0.026 & 5.25 & -4.13 & 0.76 \\
\hline RMF13 & 1300 & 0.551 & 0.133 & 0.106 & 0.038 & 0.151 & 0.013 & 0.007 & 0.049 & 5.02 & -4.40 & 0.75 \\
\hline RMF14 & 1300 & 0.537 & 0.121 & 0.095 & 0.047 & 0.178 & 0.013 & 0.006 & 0.048 & 4.87 & -4.38 & 0.75 \\
\hline RMF15 & 1300 & 0.515 & 0.125 & 0.244 & 0.054 & 0.043 & 0.013 & 0.006 & 0.028 & 4.81 & -4.14 & 0.71 \\
\hline RMF16 & 1300 & 0.492 & 0.104 & 0.300 & 0.048 & 0.038 & 0.013 & 0.006 & 0.033 & 4.8 & -4.24 & 0.70 \\
\hline RMF17 & 1300 & 0.492 & 0.104 & 0.300 & 0.048 & 0.038 & 0.013 & 0.006 & 0.045 & 4.73 & -4.37 & 0.70 \\
\hline RMF18 & 1300 & 0.455 & 0.104 & 0.363 & 0.050 & 0.037 & 0.014 & 0.005 & 0.075 & 4.55 & -4.60 & 0.67 \\
\hline RMF1 & 1350 & 0.135 & 0.326 & 0.288 & 0.059 & 0.158 & 0.026 & 0.008 & 0.110 & 4.52 & -4.71 & 0.62 \\
\hline RMF2 & 1350 & 0.362 & 0.236 & 0.198 & 0.069 & 0.103 & 0.022 & 0.010 & 0.077 & 4.89 & -4.48 & 0.68 \\
\hline RMF3 & 1350 & 0.525 & 0.176 & 0.151 & 0.051 & 0.066 & 0.018 & 0.014 & 0.063 & 4.98 & -4.22 & 0.73 \\
\hline RMF4 & 1350 & 0.612 & 0.121 & 0.136 & 0.052 & 0.051 & 0.014 & 0.014 & 0.021 & 4.90 & -3.69 & 0.77 \\
\hline RMF5 & 1350 & 0.716 & 0.086 & 0.103 & 0.036 & 0.045 & 0.0 & 0.014 & 0.019 & 4.45 & -3.64 & 0.80 \\
\hline RMF6 & 1350 & 0.782 & 0.060 & 0.072 & 0.037 & 0.035 & 0.0 & 0.014 & 0.017 & 4.25 & -3.54 & 0.84 \\
\hline RMF7 & 1350 & 0.581 & 0.200 & 0.097 & 0.057 & 0.044 & 0.014 & 0.008 & 0.022 & 4.45 & -3.96 & 0.75 \\
\hline RMF8 & 1350 & 0.587 & 0.237 & 0.095 & 0.041 & 0.043 & 0.016 & 0.008 & 0.032 & 4.39 & -4.12 & 0.74 \\
\hline
\end{tabular}


Table 4-7- Continued.

\begin{tabular}{|c|c|c|c|c|c|c|c|c|c|c|c|c|}
\hline RMF9 & 1350 & 0547 & 0240 & 0088 & 0062 & 0040 & 0013 & 0007 & 0050 & & 410 & 074 \\
\hline RMF10 & 1350 & 0.531 & 0.279 & 0.082 & 0.051 & 0.037 & 0.014 & 0.005 & 0.040 & 4.88 & -4.46 & 0.73 \\
\hline RMF11 & 1350 & 0.580 & 0.135 & 0.115 & 0.054 & 0.096 & 0.012 & 0.008 & 0.017 & 5.11 & -3.87 & 0.76 \\
\hline RMF12 & 1350 & 0.580 & 0.130 & 0.112 & 0.037 & 0.122 & 0.013 & 0.007 & 0.025 & 4.90 & -4.07 & 0.76 \\
\hline RMF13 & 1350 & 0.556 & 0.129 & 0.103 & 0.047 & 0.145 & 0.013 & 0.007 & 0.059 & 4.74 & -4.42 & 0.75 \\
\hline RMF14 & 1350 & 0.557 & 0.118 & 0.097 & 0.046 & 0.163 & 0.012 & 0.007 & 0.060 & 4.66 & -4.43 & 0.76 \\
\hline RMF15 & 1350 & 0.527 & 0.122 & 0.256 & 0.034 & 0.042 & 0.013 & 0.006 & 0.020 & 4.68 & -4.01 & 0.71 \\
\hline RMF16 & 1350 & 0.498 & 0.100 & 0.293 & 0.054 & 0.037 & 0.012 & 0.006 & 0.034 & 4.61 & -4.25 & 0.70 \\
\hline RMF17 & 1350 & 0.481 & 0.092 & 0.329 & 0.046 & 0.035 & 0.011 & 0.005 & 0.049 & 4.62 & -4.45 & 0.69 \\
\hline RMF18 & 1350 & 0.462 & 0.089 & 0.349 & 0.052 & 0.032 & 0.010 & 0.006 & 0.048 & 4.46 & -4.38 & 0.68 \\
\hline RMF1 & 1400 & 0.143 & 0.324 & 0.301 & 0.050 & 0.154 & 0.019 & 0.688 & 0.095 & 4.08 & -4.64 & 0.62 \\
\hline RMF2 & 1400 & 0.370 & 0.240 & 0.199 & 0.053 & 0.108 & 0.019 & 1.017 & 0.025 & 4.90 & -3.99 & 0.68 \\
\hline RMF3 & 1400 & 0.531 & 0.182 & 0.156 & 0.037 & 0.068 & 0.012 & 1.47 & 0.010 & 4.80 & -3.42 & 0.72 \\
\hline RMF4 & 1400 & 0.622 & 0.106 & 0.163 & 0.031 & 0.051 & 0.013 & 1.69 & 0.008 & 4.74 & -3.25 & 0.76 \\
\hline RMF5 & 1400 & 0.717 & 0.087 & 0.109 & 0.025 & 0.050 & 0.0 & 0.012 & 0.007 & 4.68 & -3.27 & 0.80 \\
\hline RMF6 & 1400 & 0.779 & 0.066 & 0.074 & 0.031 & 0.037 & 0.0 & 0.012 & 0.008 & 4.90 & -3.32 & 0.84 \\
\hline RMF7 & 1400 & 0.594 & 0.209 & 0.108 & 0.035 & 0.047 & 0.013 & 0.678 & 0.012 & 4.27 & -3.77 & 0.74 \\
\hline RMF8 & 1400 & 0.560 & 0.234 & 0.099 & 0.050 & 0.043 & 0.009 & 0.646 & 0.015 & 4.01 & -3.86 & 0.74 \\
\hline RMF9 & 1400 & 0.546 & 0.262 & 0.092 & 0.044 & 0.042 & 0.009 & 0.525 & 0.019 & 4.24 & -4.08 & 0.73 \\
\hline RMF10 & 1400 & 0.534 & 0.278 & 0.085 & 0.052 & 0.036 & 0.011 & 0.451 & 0.025 & 4.99 & -4.35 & 0.73 \\
\hline RMF11 & 1400 & 0.599 & 0.130 & 0.122 & 0.033 & 0.096 & 0.013 & 1.006 & 0.015 & 4.56 & -3.73 & 0.76 \\
\hline RMF12 & 1400 & 0.580 & 0.130 & 0.115 & 0.037 & 0.120 & 0.011 & 0.868 & 0.036 & 4.55 & -4.17 & 0.75 \\
\hline RMF13 & 1400 & 0.546 & 0.132 & 0.107 & 0.048 & 0.148 & 0.011 & 0.849 & 0.049 & 4.45 & -4.31 & 0.75 \\
\hline RMF14 & 1400 & 0.565 & 0.124 & 0.106 & 0.028 & 0.161 & 0.009 & 0.893 & 0.078 & 4.44 & -4.48 & 0.75 \\
\hline RMF15 & 1400 & 0.530 & 0.117 & 0.262 & 0.034 & 0.040 & 0.011 & 0.744 & 0.021 & 4.55 & -4.01 & 0.71 \\
\hline RMF16 & 1400 & 0.516 & 0.099 & 0.292 & 0.041 & 0.037 & 0.009 & 0.616 & 0.029 & 4.42 & -4.22 & 0.70 \\
\hline RMF17 & 1400 & 0.495 & 0.088 & 0.335 & 0.037 & 0.031 & 0.009 & 0.584 & 0.028 & 4.51 & -4.23 & 0.69 \\
\hline RMF18 & 1400 & 0.478 & 0.081 & 0.359 & 0.038 & 0.030 & 0.009 & 0.583 & 0.032 & 4.37 & -4.28 & 0.68 \\
\hline
\end{tabular}




\subsubsection{Effect of the basicity on the sulphide capacity of red mud based fluxes}

The relationship between the sulphide capacity and the optical basicity, as a unified measure of the flux basicity, is shown in Figure 4-6 for the temperature range of $1300-1400{ }^{\circ} \mathrm{C}$. The results show the sulphide capacity increases with increasing optical basicity and temperature. The effect of temperature is more evident at higher optical basicity. The sulphide capacity reaches a maximum at optical basicity of $0.76-0.77$ for all the temperatures, indicating this as the optimum value, beyond which the sulphide capacity does not increase. As will be discussed later, this is the point where the flux is saturated with $\mathrm{CaO}$. In order to investigate the effect of individual flux components on sulphide capacity, flux RMF4 was chosen as the basis, as it corresponds to the composition with optical basicity of $\sim 0.77$.

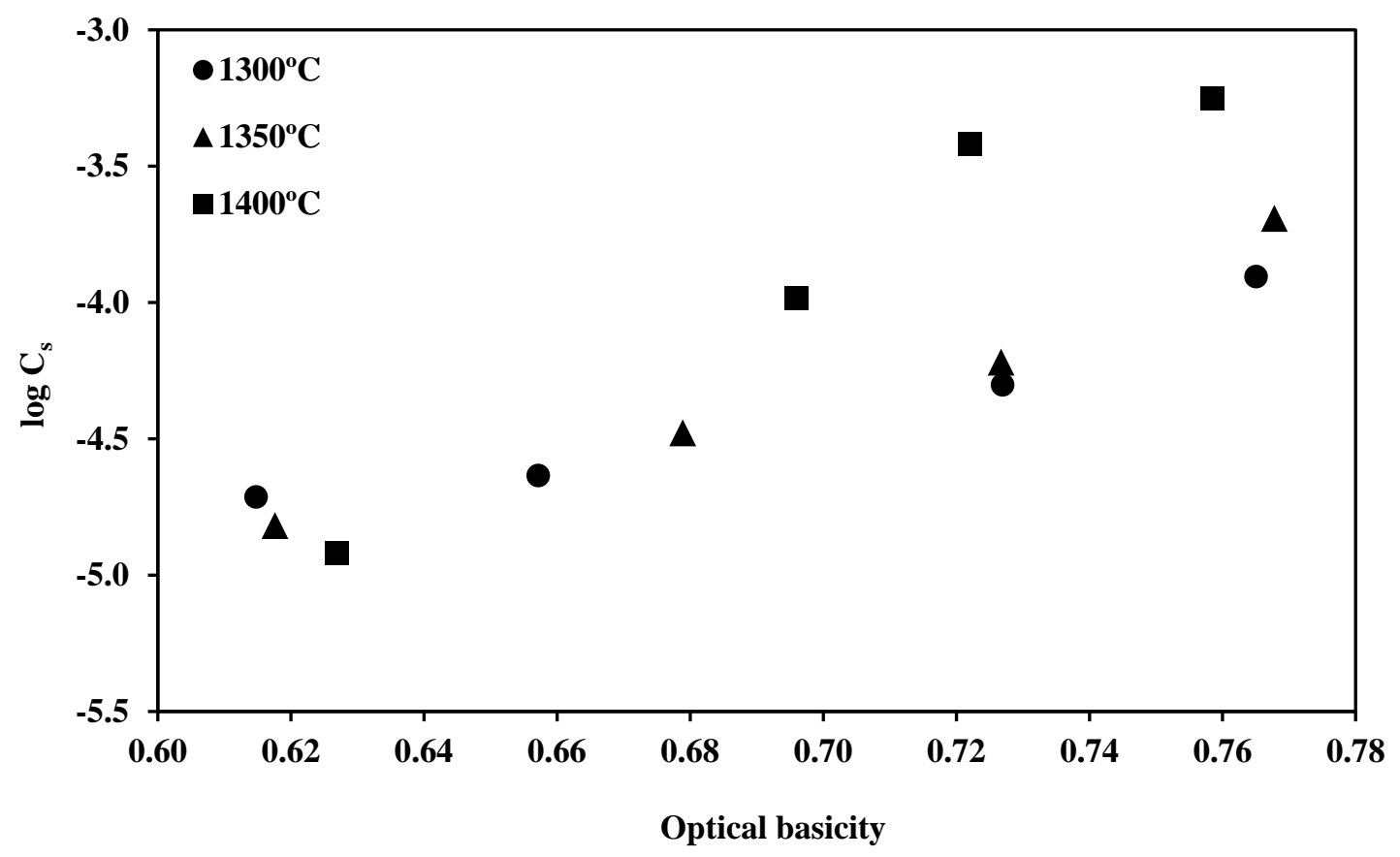

Figure 4-6: Relationship between sulphide capacity and optical basicity

\subsubsection{Effect of $\mathrm{CaO}$ on the optical basicity and the sulphide capacity of the red mud based fluxes}

The degree of the silicate network polymerization can dictate the sulphur absorption capacity of the liquid flux. Lime, as a basic component, is known to contribute to depolymerisation of the 
silicate network and increases the activity of the oxygen ion $\left(\mathrm{O}^{2-}\right)$ leading to higher optical basicity, Figure 4-7.

The relationship between sulphide capacity and the $\mathrm{CaO}$ content is shown in Figure 4-8. The sulphide capacity increases with increasing lime for all temperatures. The trend appears to change at $\mathrm{X}_{\mathrm{CaO}} \sim 0.6$, above which addition of lime does not improve the sulphide capacity (RMF4 through RMF6). XRD analysis was carried out on the samples RMF3, RMF4, RMF5 and RMF6, with the results provided in Appendix 4 (Figure A4-1 - Figure A4-4).

The obtained results revealed peaks for free lime in the sample RMF5 and RMF6 but not for samples RMF3 and RMF4. Therefore, RMF4 sample containing 32.8\% CaO was considered as the point where the flux is just saturated with $\mathrm{CaO}$. This is well consistent with the trend of sulphide capacity that reaches a plateau at the same concentration. Addition of lime over the saturation concentration results in undissolved lime that does not contribute to desulphurization, as the activity of $\mathrm{CaO}$ and $\mathrm{O}^{2-}$ and the extent of flux depolymerisation remain unchanged. In fact, due to the formation of solid phases in the molten flux, the kinetics of the desulphurization is slowed as the flux viscosity is increased.

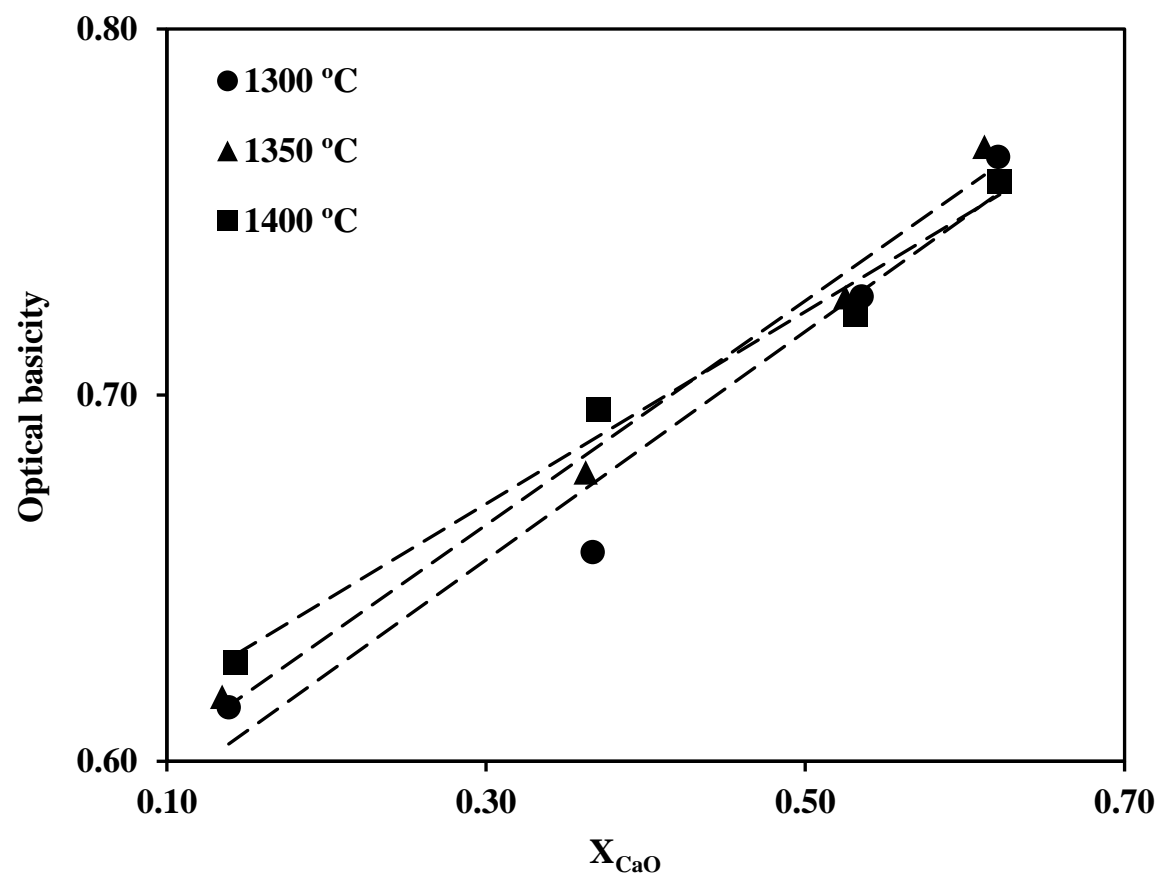

Figure 4-7: Relationship between optical basicity and mole fraction of lime in the red mud based fluxes 
As a result of the high temperature nature of experiments and the long hours needed for achieving equilibrium condition, it is not customary to repeat all the experiments in the high temperature equilibrium studies. Thus, in this study samples (RMF1 through RMF6) with different $\mathrm{CaO}$ concentration were chosen to test the repeatability of the experiments. These samples were treated three times at the $1350{ }^{\circ} \mathrm{C}$. The resulting measurement of these treatments had a standard deviation about $\pm 5 \%$ of the calculated sulphide capacity values at $1350{ }^{\circ} \mathrm{C}$ for each sample.

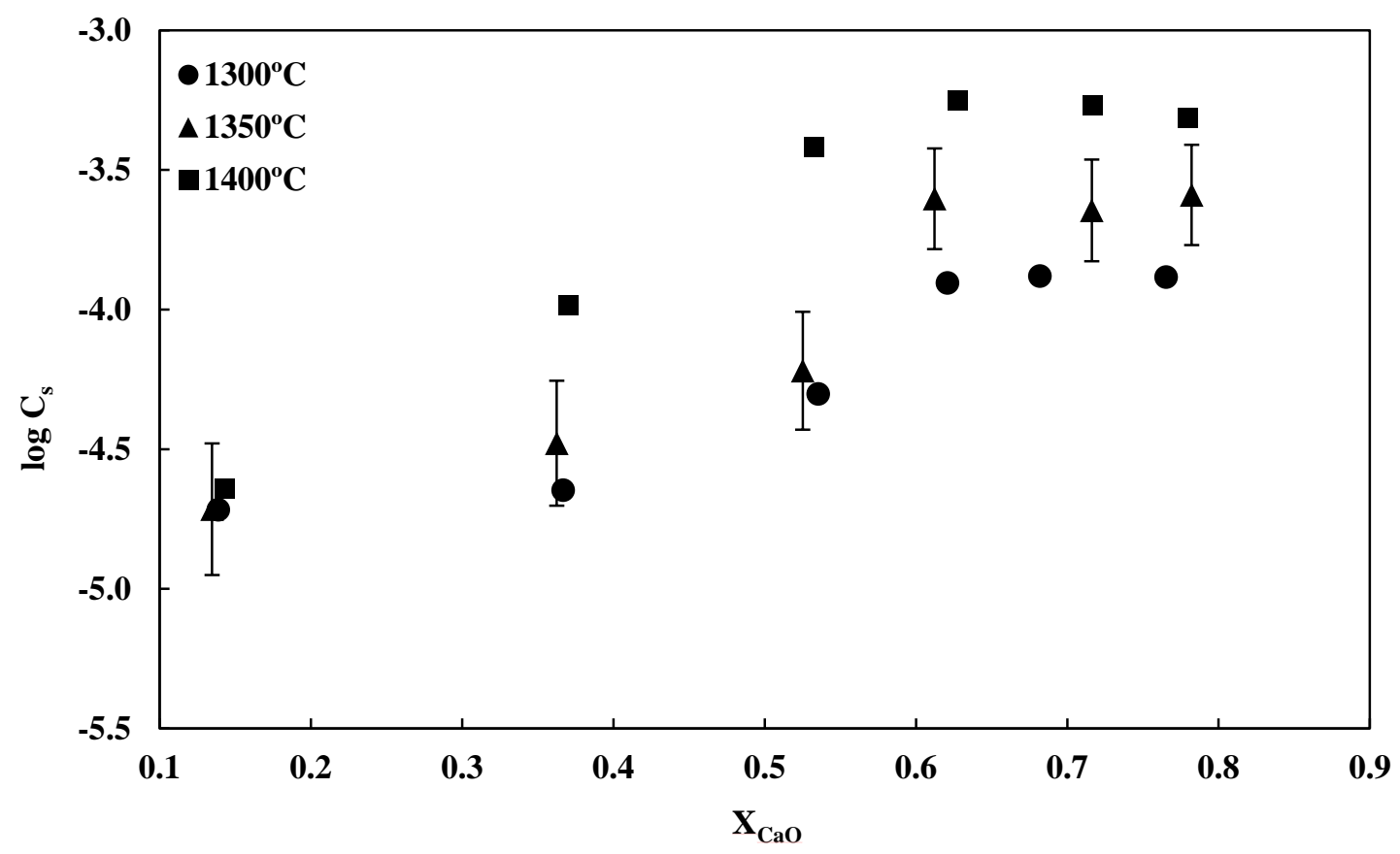

Figure 4-8: Effect of $\mathrm{CaO}$ on the sulphide capacity at different temperatures Error bars were determined for $1350^{\circ} \mathrm{C}$ only.

\subsubsection{Effect of $\mathrm{Al}_{2} \mathrm{O}_{3}, \mathrm{TiO}_{2}$ and $\mathrm{SiO}_{2}$ on the optical basicity and sulphide capacity of the red mud fluxes}

In order to investigate the effect of other oxide additives on the sulphide capacity, different amounts of $\mathrm{Al}_{2} \mathrm{O}_{3}, \mathrm{TiO}_{2}$ and $\mathrm{SiO}_{2}$ were added to the flux RMF4 which was found to exhibit the highest sulphide capacity. The final compositions and sulphide capacities for new composition are shown in Table 4-7. 
The results in Figure 4-9 (RMF7 through RMF10) and Figure 4-10 (RMF11 through RMF14) show the effect of $\mathrm{Al}_{2} \mathrm{O}_{3}$ and $\mathrm{TiO}_{2}$ on the sulphide capacity of the red mud based fluxes in the temperature range of $1300{ }^{\circ} \mathrm{C}$ to $1400{ }^{\circ} \mathrm{C}$ respectively. It can be seen that the sulphide capacity decreases with increasing the concentration of both components. Alumina and titanium oxide are known as amphoteric oxides that depending on the total flux composition can perform as either network modifiers or network formers. In highly basic fluxes used here (RMF4), these oxides behave as network former [34].

$\mathrm{Ti}_{4}{ }^{+}$and $\mathrm{Al}_{3}{ }^{+}$form tetrahedra and can be incorporated into the silicate network as $\mathrm{TiO}_{4}{ }^{4-}$ and $\mathrm{AlO}_{4}{ }^{5-}$ species. The charge balance can be maintained by other ions such as $\mathrm{Na}^{+}$or $\mathrm{Ca}^{2+}$ so that these cations do not participate in depolymerization of the silicate network [34], thus the "effective" concentration of basic components decreases. In other words, $\mathrm{Al}_{2} \mathrm{O}_{3}$ and $\mathrm{TiO}_{2}$ promote polymerization of the flux structures and decrease mole fraction of the free oxygen ion $\left(\mathrm{O}^{2-}\right)$.

Figure 4-11 and Figure 4-12 show the effect of alumina and titania addition respectively on the optical basicity of the fluxes in the temperature range of $1300{ }^{\circ} \mathrm{C}-1400{ }^{\circ} \mathrm{C}$. It is clear that both oxides decrease the optical basicity, in accordance with their effect on the sulphide capacity.

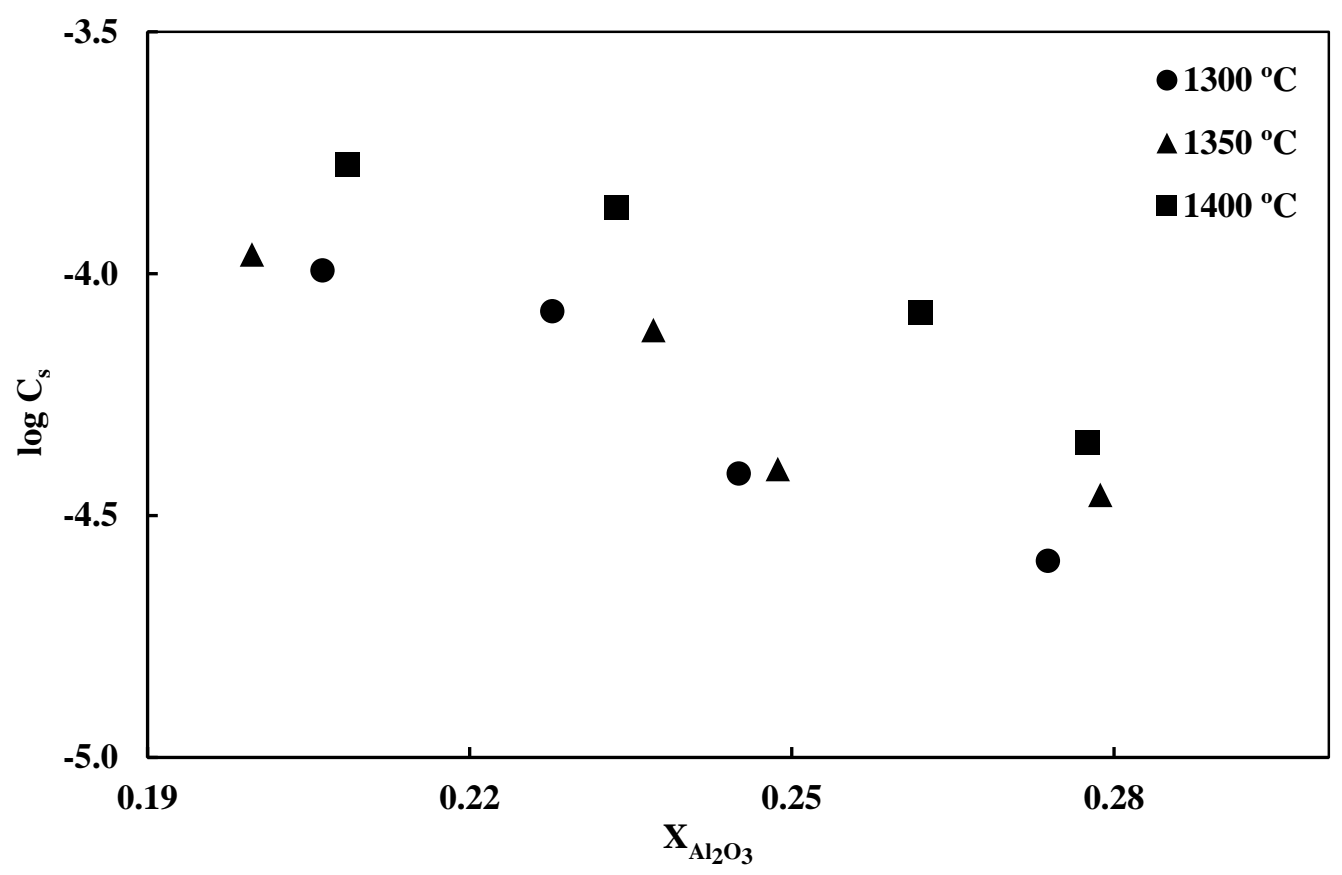

Figure 4-9: Effect of $\mathrm{Al}_{2} \mathrm{O}_{3}$ on the sulphide capacity at different temperatures 


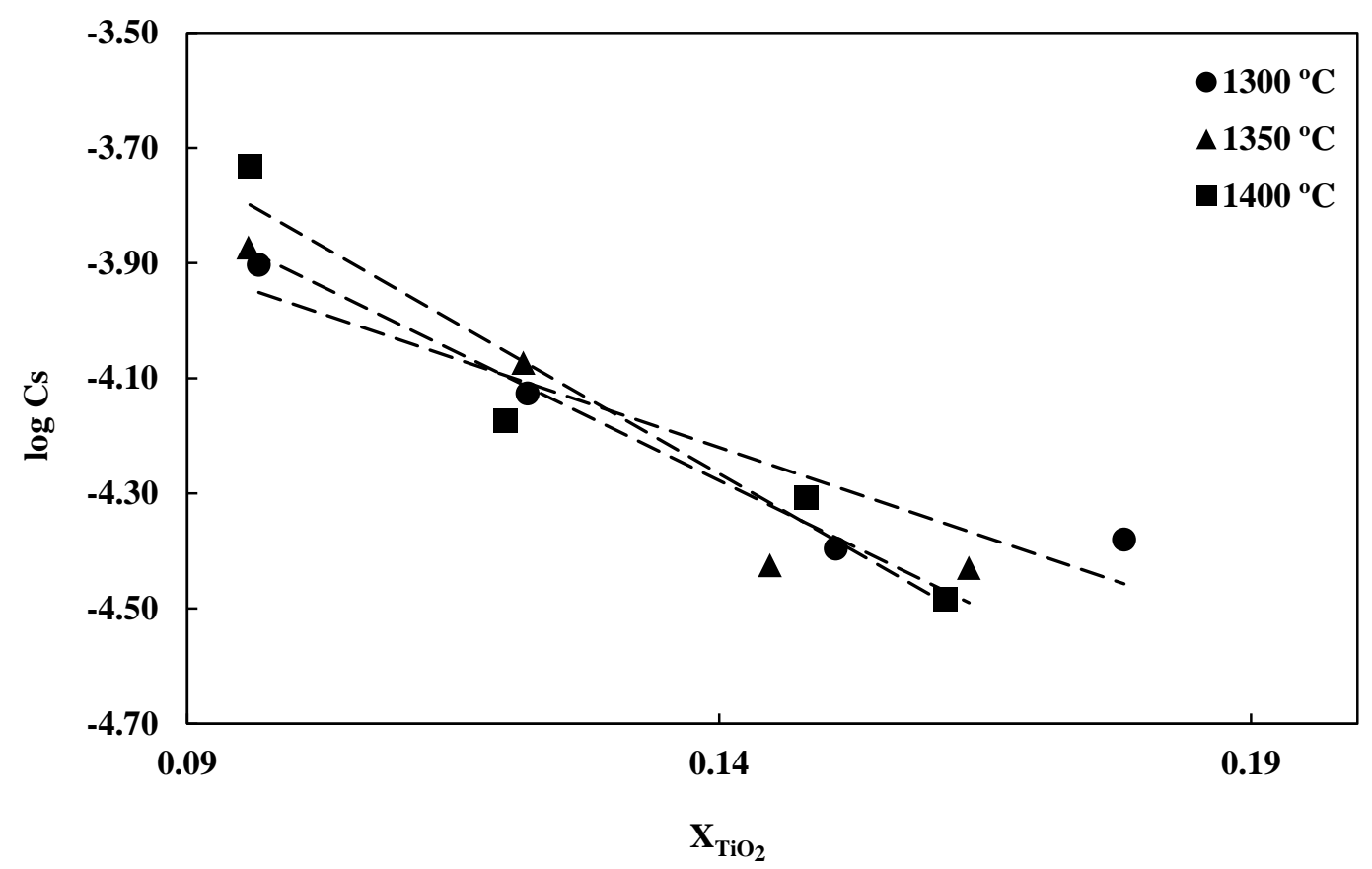

Figure 4-10: Effect of $\mathrm{TiO}_{2}$ on the sulphide capacity at different temperatures

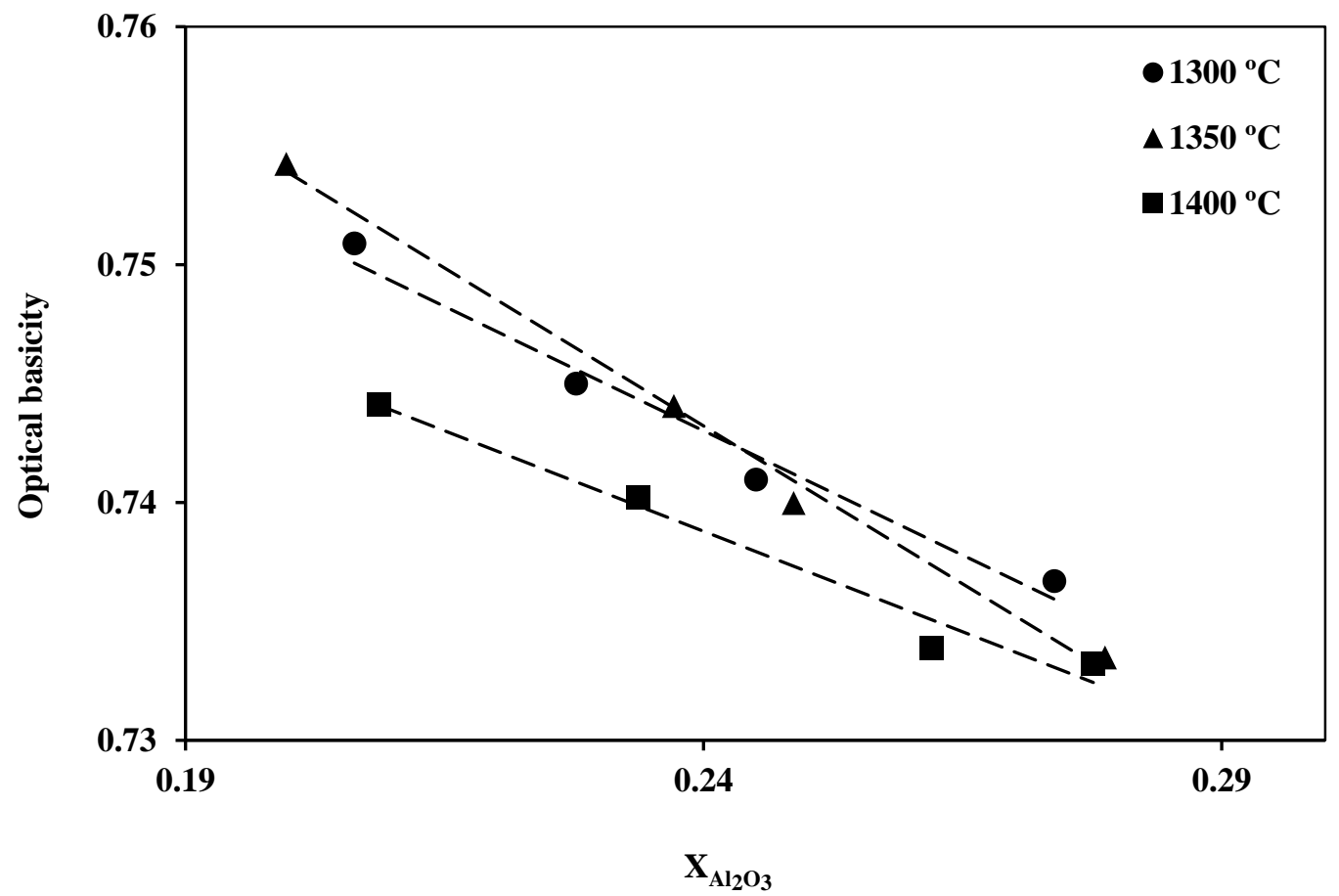

Figure 4-11: Effect of $\mathrm{Al}_{2} \mathrm{O}_{3}$ on the optical basicity at different temperatures 


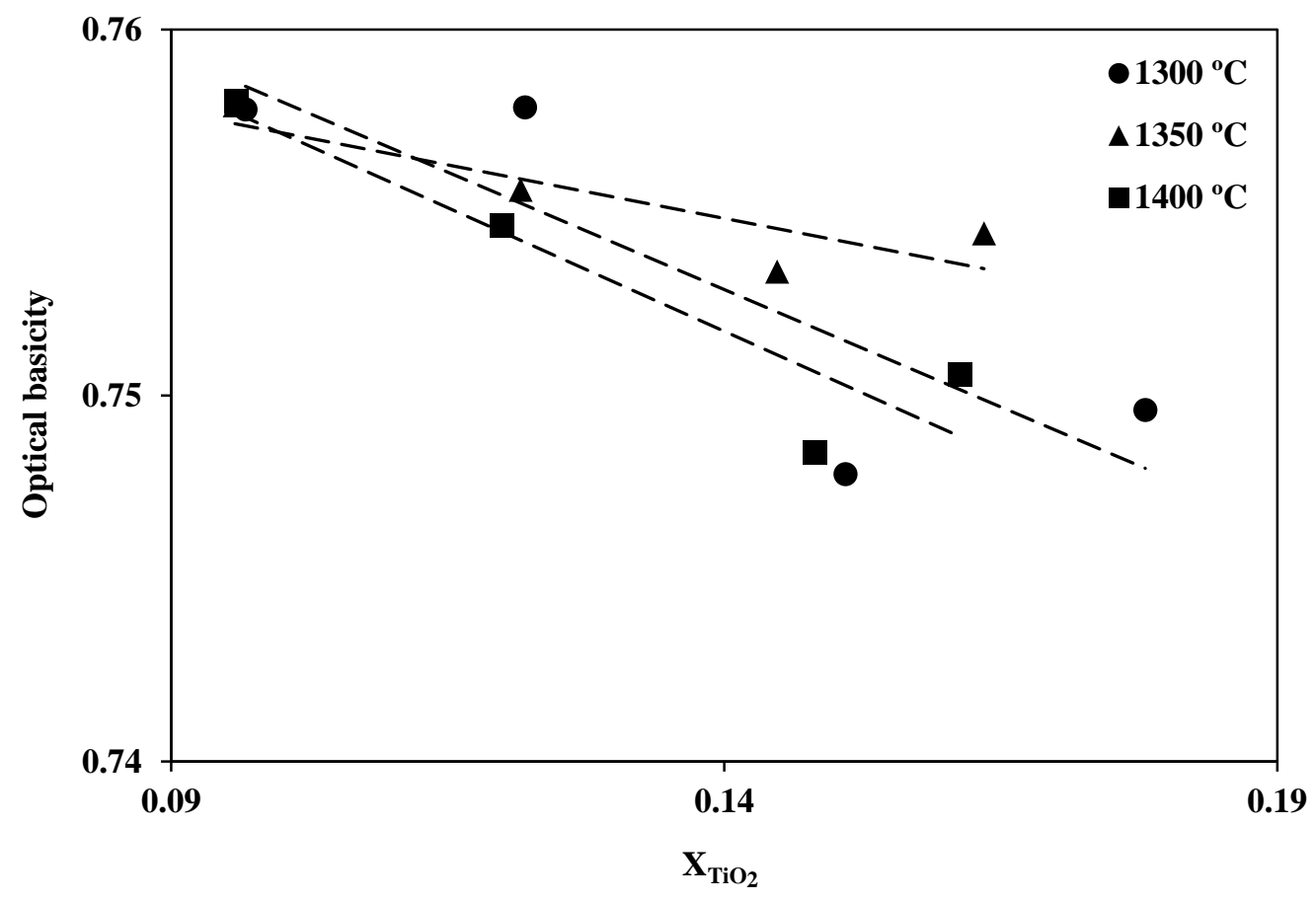

Figure 4-12: Effect of $\mathrm{TiO}_{2}$ on the optical basicity at different temperatures

The effect of $\mathrm{SiO}_{2}$ on the sulphide capacity of the flux (RMF15 through RMF18) in the in the range of $1300-1400{ }^{\circ} \mathrm{C}$ is plotted in Figure 4-13. It can be seen that the sulphide capacity decreases with increasing $\mathrm{SiO}_{2}$ content regardless of the temperature. $\mathrm{SiO}_{2}$ is a network former and increases the degree of the polymerization in the flux structure, which is evidenced by a decrease in the availability of the free oxygen ions $\left(\mathrm{O}^{2-}\right)$ Figure 4-14 [105]. The effect would then obviously be a drop in sulphide capacity as the $\mathrm{SiO}_{2}$ content increases. 


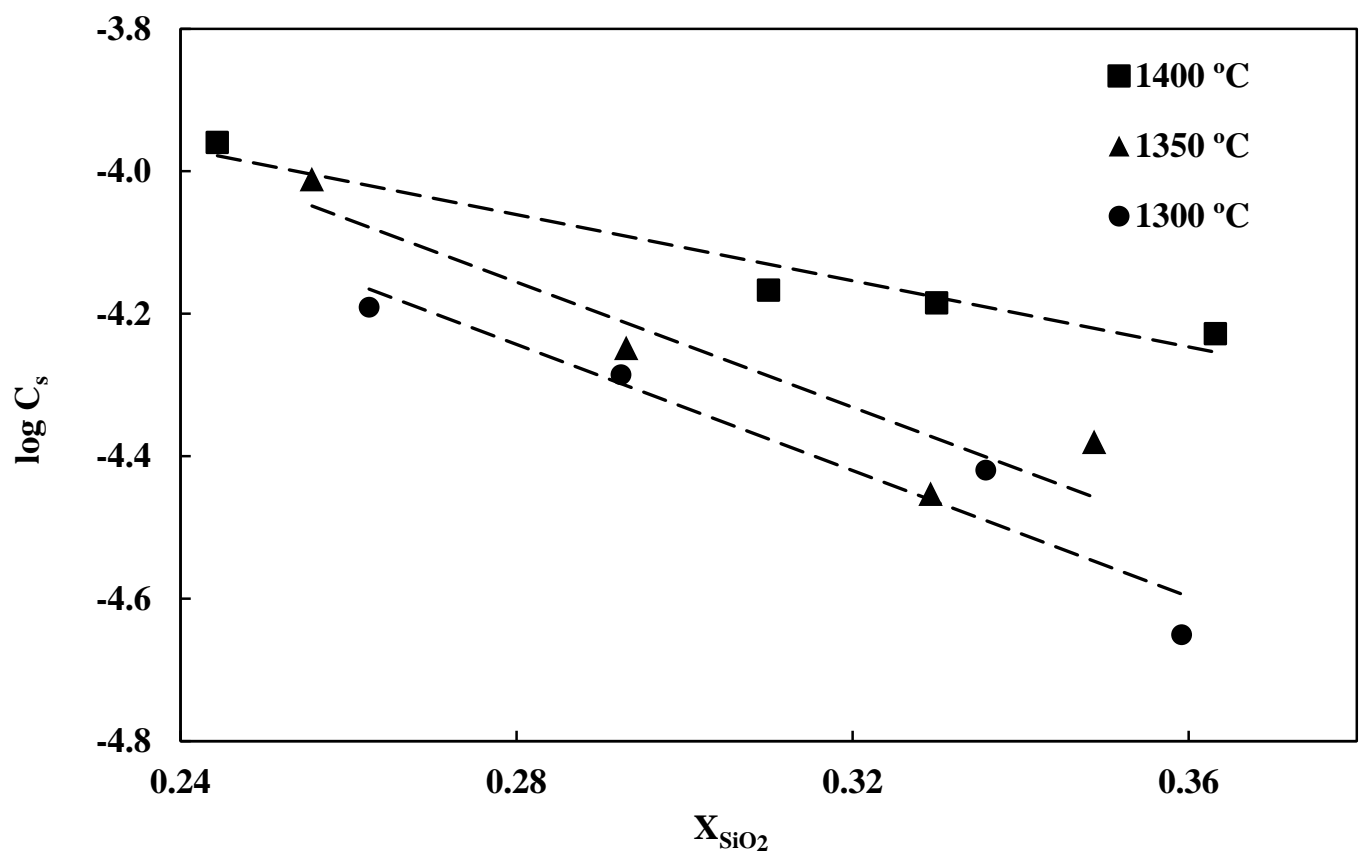

Figure 4-13: Effect of $\mathrm{SiO}_{2}$ on the sulphide capacity at different temperatures

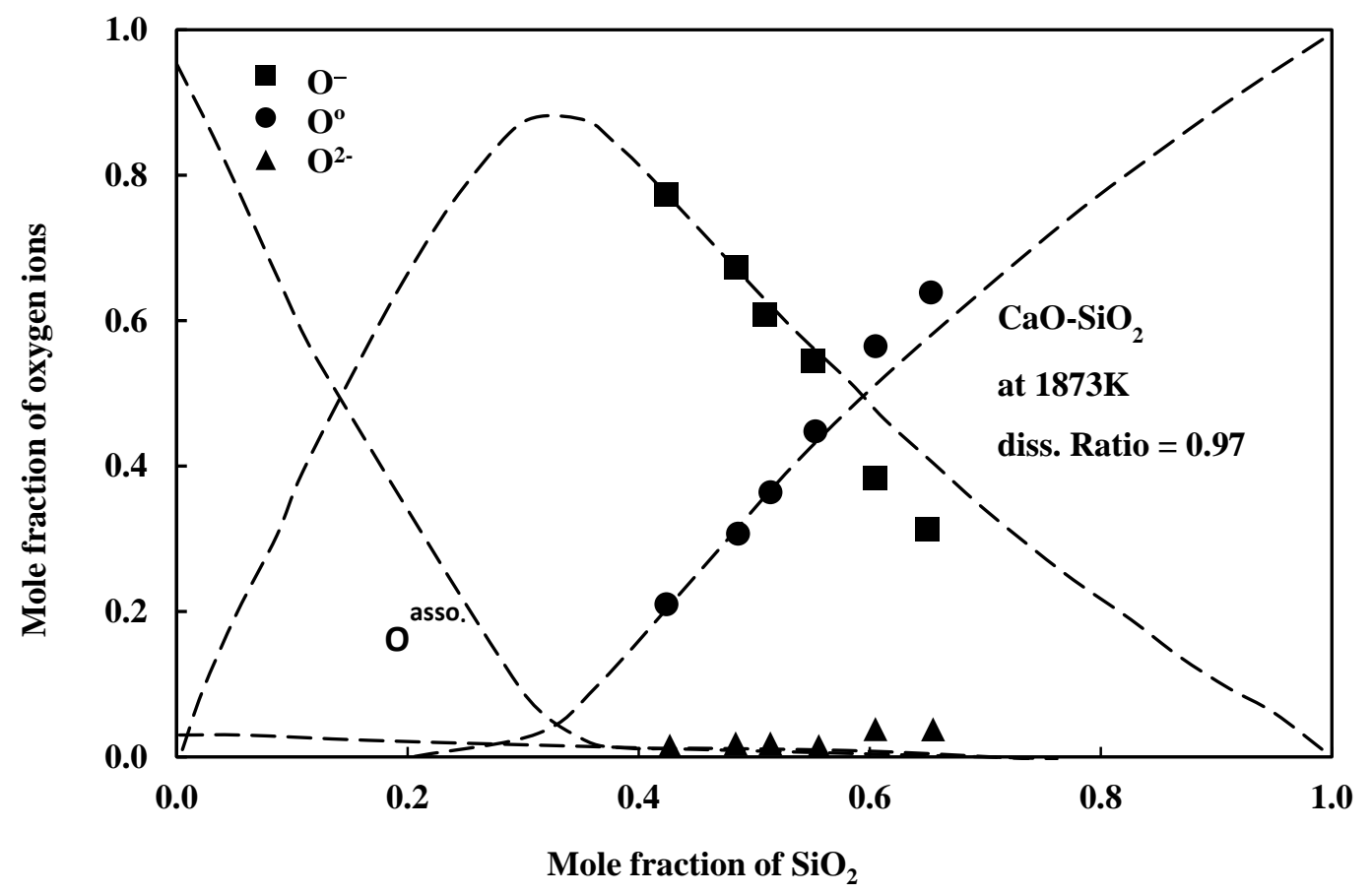

Figure 4-14: Effect of $\mathrm{SiO}_{2}$ on the different oxygen bondings [105] 


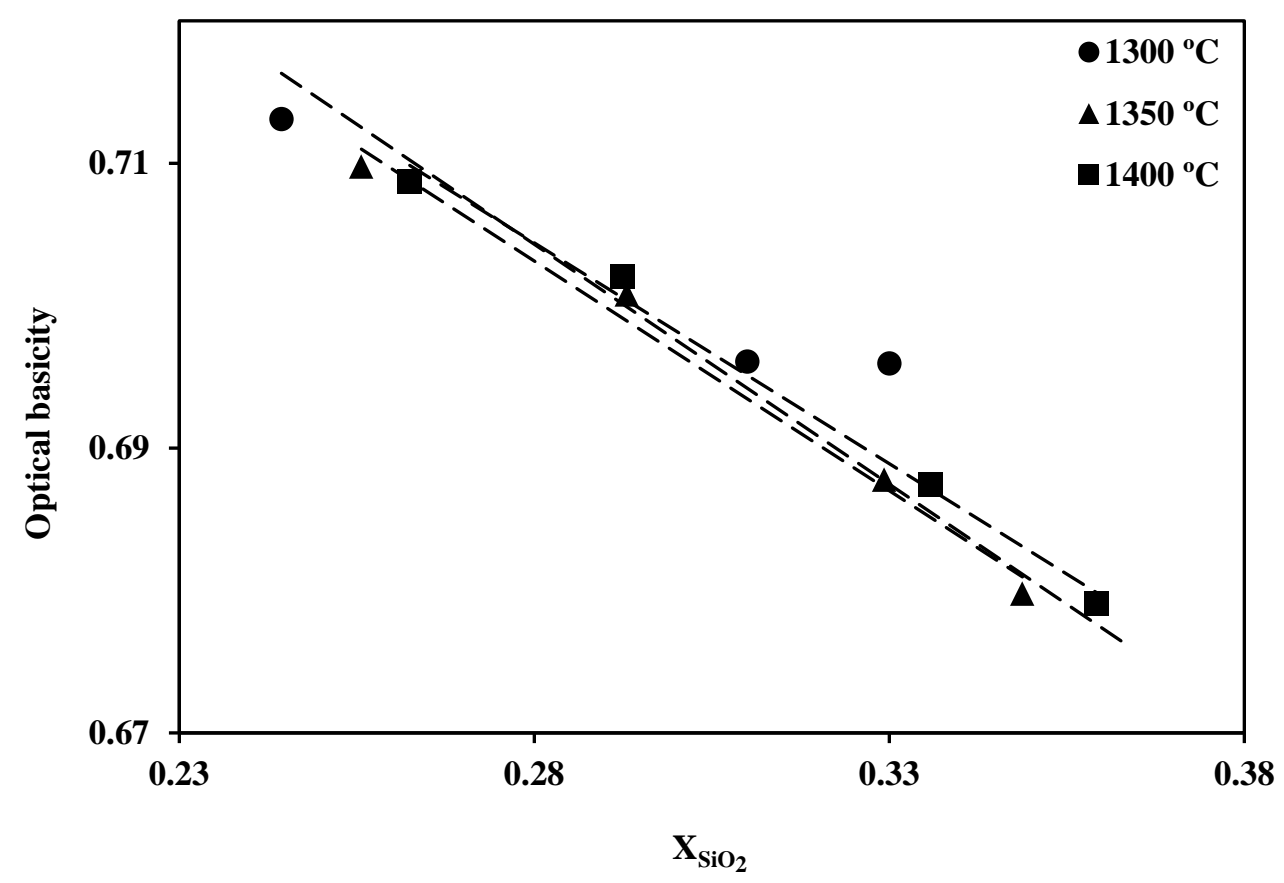

Figure 4-15- Effect of $\mathrm{SiO}_{2}$ on optical basicity at different temperatures

\subsubsection{Effect of temperature on the sulphide capacity of red mud based fluxes}

Temperature should have a positive effect on the sulphide capacity as described earlier. The obtained sulphide capacity data are plotted against reciprocal temperature in Figure 4-16, confirming that an increase in temperature results in higher sulphide capacity which would be in accordance with the increase of free oxygen ions due to the breaking of the bonds [47]. Separate lines for fluxes with approximately equal optical basicity have been plotted. The difference in the slope of the lines is believed to be because of the effect of the optical basicity as discussed below. Values are shown using separate lines. It should be noted that the variation of line slopes is correlated to the optical basicity values and hence with flux composition.

The equilibrium constant $(\mathrm{K})$ for the sulphur removal reaction can be related to temperature through a form of Van't Hoff's equation $[41,47,106]$ where $\Delta H$ is the reaction enthalpy.

$$
\frac{\mathrm{d} \ln \mathrm{K}}{\mathrm{d}(1 / \mathrm{T})}=-\frac{\Delta \mathrm{H}}{\mathrm{R}}
$$


In the presence of lime as the main basic component of slag, the desulphurization reaction can be expressed as follows:

$\mathrm{CaO}(\mathrm{s})+\frac{1}{2} \mathrm{~S}_{2}(\mathrm{~g})=\mathrm{CaS}(\mathrm{s})+\frac{1}{2} \mathrm{O}_{2}(\mathrm{~g}) \Delta \mathrm{G}^{\circ}=92000-2.55 \mathrm{~T}\left(\frac{\mathrm{J}}{\mathrm{mol}}\right)$

From the equilibrium constant of Reaction 4-13 and Equation 4-12 the relation between flux sulphide capacity and temperature can be simplified as:

$\frac{d\left(\log C_{S}\right)}{d\left(\frac{1}{T}\right)}=\frac{-\Delta H}{2.303 R}$

4-14

Therefore, the slope of the lines in Figure 4-16 can be correlated to the enthalpy of the desulphurization reactions, which could be a combination of Reaction 4-13 together with dissolution of oxygen and sulphur into metal and $\mathrm{CaO} / \mathrm{CaS}$ into slag. The enthalpy of the overall sulphur pick up process was calculated and plotted against the optical basicity in Figure 4-17, which increases from $99.8 \mathrm{~kJ} / \mathrm{mole}$ at an optical basicity of 0.62 to $338.9 \mathrm{~kJ} / \mathrm{mole}$ at an optical basicity of 0.77 .

The present results are in good agreement with the temperature dependence of the sulphide capacities reported by previous researchers for different compositions [47, 48, 50, 52]. Hence, the obtained results are plotted in Figure 4-18 with other published data [47, 48, 50, 52]. Although previous findings are in different slag systems and temperatures, the trends are similar. It also can be seen that the slope slightly increased with increasing optical basicity in all systems. 


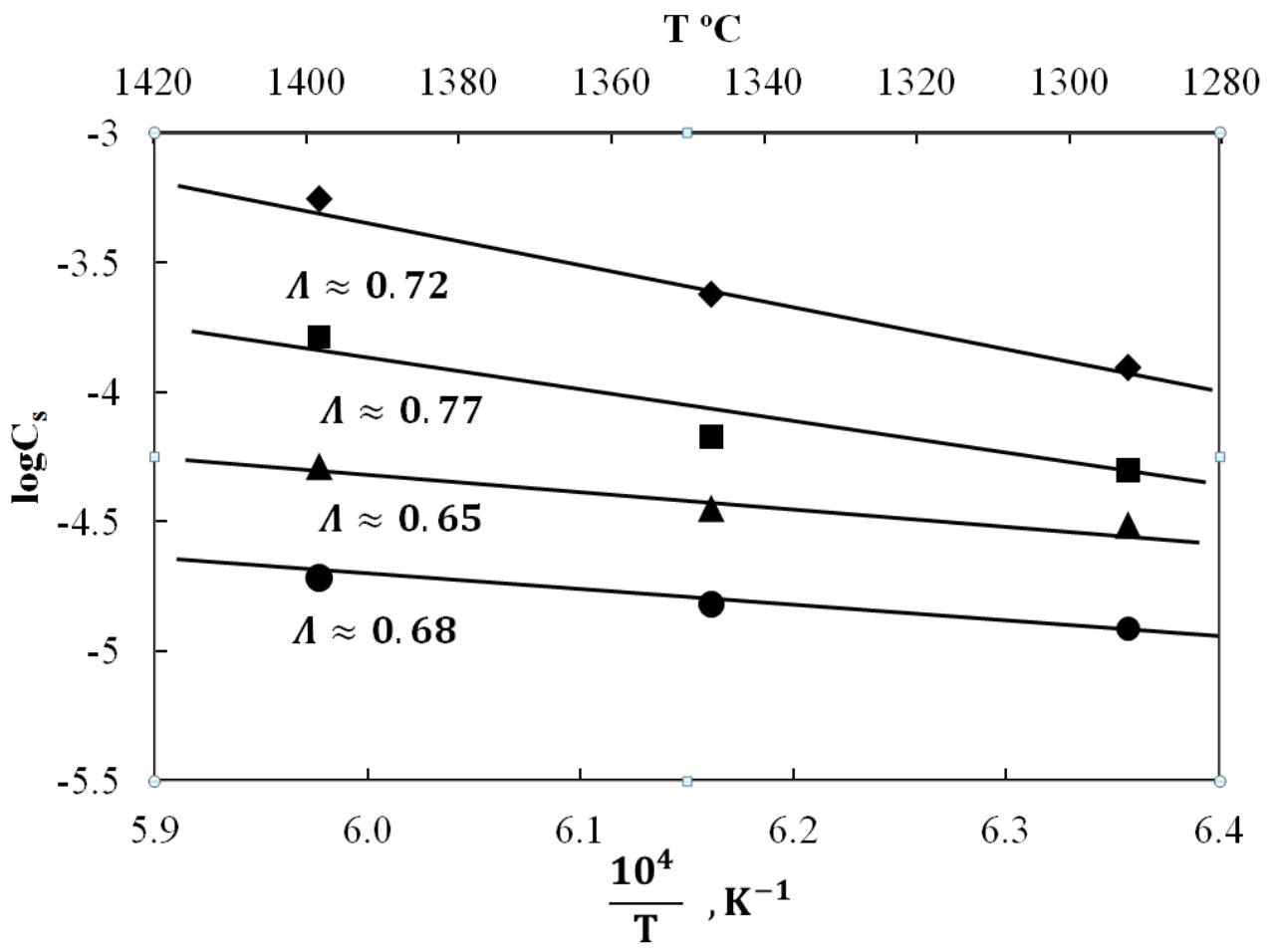

Figure 4-16: Relationship between sulphide capacity and temperature

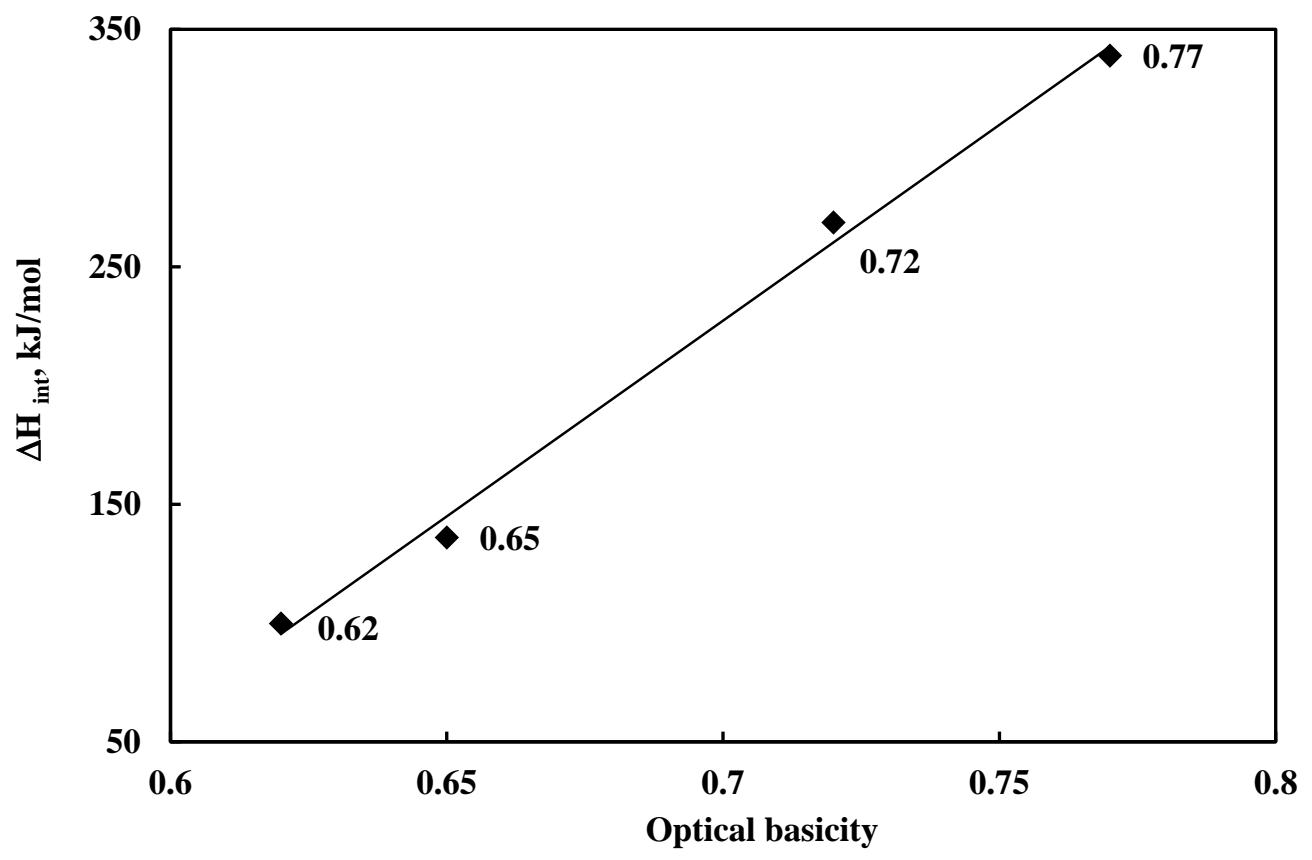

Figure 4-17- Relationship between the enthalpy of sulphur transfer to flux and optical basicity 


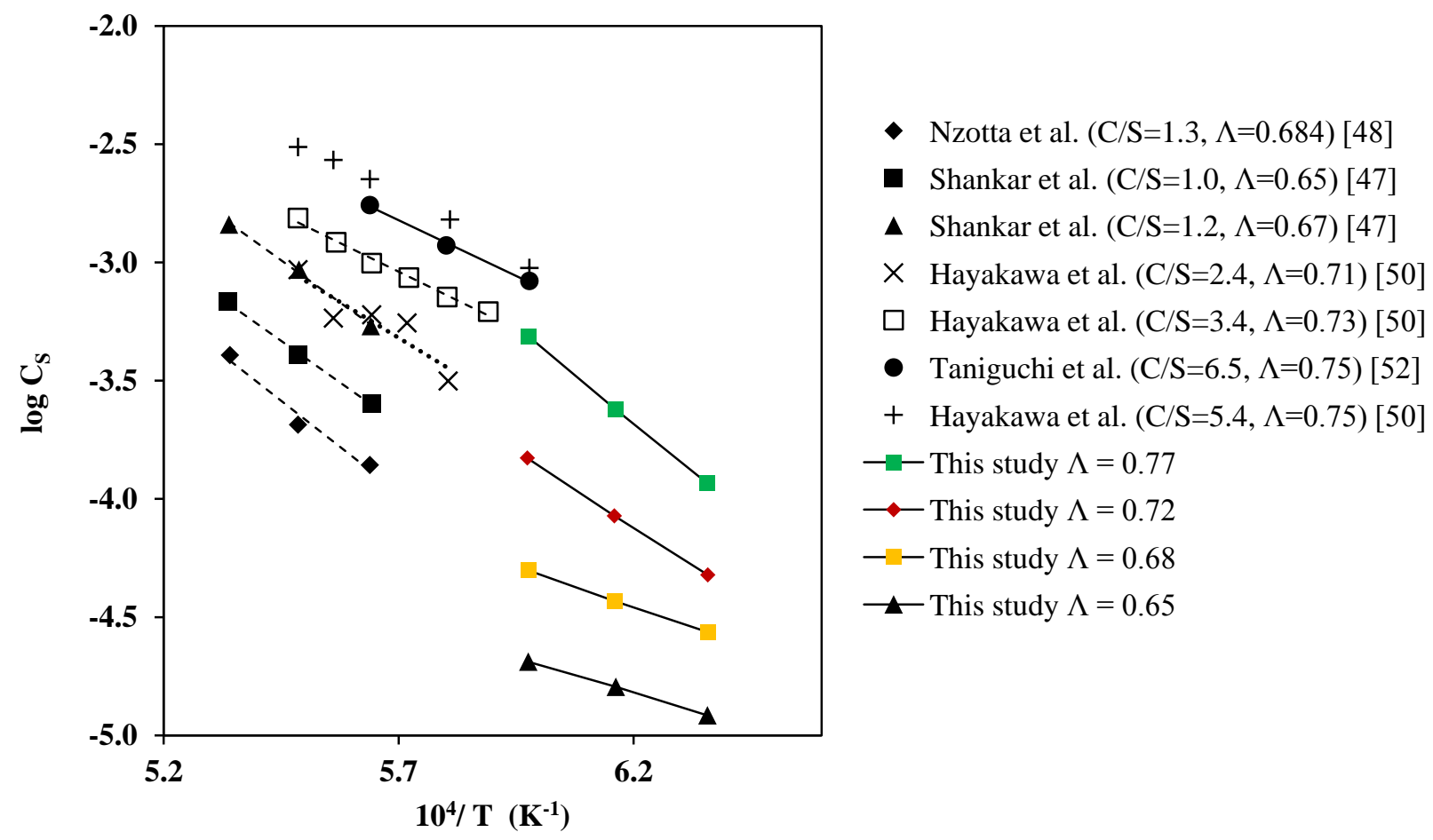

Figure 4-18: Relationship between $\log \mathrm{C}_{\mathrm{s}}$ and temperature (data from this study and literatures)

\subsection{Dephosphorization studies}

Red mud based fluxes with high iron oxide content cannot be equilibrated with carbon-saturated iron as the iron oxide is reduced. Thus, in this study, the phosphorus distribution ratio in the temperature range of $1300-1400{ }^{\circ} \mathrm{C}$ is experimentally determined between the synthetic red mud based flux and a strip of pure solid iron. The results can then be extended to calculate the distribution of phosphorous between slag and liquid iron, considering the thermodynamics of fusion of iron $[85,87]$. This method was developed by Sano and his coworkers $[84,85]$.

Table 4-8 presents the chemical composition of the initial fluxes, which were prepared using reagent grade $\mathrm{CaO}, \mathrm{Al}_{2} \mathrm{O}_{3}, \mathrm{TiO}_{2}, \mathrm{SiO}_{2}, \mathrm{CaHPO}_{4}, \mathrm{Na}_{2} \mathrm{CO}_{3}$ and synthetic $\mathrm{FeO}$ (wustite) as additives. 
Table 4-8: Initial chemical compositions of synthetic red mud based fluxes used in the experiments

\begin{tabular}{|c|c|c|c|c|c|c|c|}
\hline & \multicolumn{7}{|c|}{ Composition $\mathrm{wt} \%$} \\
\cline { 2 - 8 } Flux No. & $\mathrm{FeO}$ & $\mathrm{Al}_{2} \mathrm{O}_{3}$ & $\mathrm{TiO}_{2}$ & $\mathrm{CaO}$ & $\mathrm{Na}_{2} \mathrm{O}$ & $\mathrm{SiO}_{2}$ & $\mathrm{P}_{2} \mathrm{O}_{5}$ \\
\hline SRM-1 & 41.9 & 18.0 & 7.2 & 3.6 & 9.0 & 10.4 & 10.0 \\
\hline SRM-2 & 37.2 & 16.0 & 6.4 & 13.2 & 8.0 & 9.2 & 10.0 \\
\hline SRM-3 & 32.6 & 14.0 & 5.6 & 22.8 & 7.0 & 8.1 & 10.0 \\
\hline SRM-4 & 27.9 & 12.0 & 4.8 & 32.4 & 6.0 & 6.9 & 10.0 \\
\hline SRM-5 & 23.3 & 10.0 & 4.0 & 42.0 & 5.0 & 5.8 & 10.0 \\
\hline SRM-6 & 18.6 & 8.0 & 3.2 & 51.6 & 4.0 & 4.6 & 10.0 \\
\hline SRM-7 & 25.4 & 20.0 & 4.4 & 29.5 & 5.5 & 6.3 & 9.1 \\
\hline SRM-8 & 24.3 & 23.5 & 4.2 & 28.2 & 5.2 & 6.0 & 8.7 \\
\hline SRM-9 & 23.3 & 26.7 & 4.0 & 27.0 & 5.0 & 5.8 & 8.3 \\
\hline SRM-10 & 22.3 & 29.6 & 3.8 & 25.9 & 4.8 & 5.5 & 8.0 \\
\hline SRM-11 & 26.6 & 11.4 & 9.3 & 30.9 & 5.7 & 6.6 & 9.5 \\
\hline SRM-12 & 25.8 & 11.1 & 11.9 & 30.0 & 5.6 & 6.4 & 9.3 \\
\hline SRM-13 & 24.9 & 10.7 & 15.0 & 28.9 & 5.4 & 6.2 & 8.9 \\
\hline SRM-14 & 24.3 & 10.4 & 17.2 & 28.2 & 5.2 & 6.0 & 8.7 \\
\hline SRM-15 & 25.4 & 10.9 & 4.4 & 29.5 & 5.5 & 15.4 & 9.1 \\
\hline SRM-16 & 24.3 & 10.4 & 4.2 & 28.2 & 5.2 & 19.0 & 8.7 \\
\hline SRM-17 & 23.3 & 10.0 & 4.0 & 27.0 & 5.0 & 22.4 & 8.3 \\
\hline SRM-18 & 22.3 & 9.6 & 3.8 & 25.9 & 4.8 & 25.5 & 8.0 \\
\hline
\end{tabular}

\subsubsection{Synthetic iron (II) oxide preparation}

In this study, synthetic $\mathrm{FeO}$ (wustite) was prepared by equilibrating iron (III) oxide (hematite) and pure iron powders at high temperature. Then X-ray diffraction examination was performed to verify transformation of hematite to wustite, as seen in Figure 4-19 for a typical experiment. In 
this figure, a small peak for metallic iron is identified at around $2 \theta=42^{\circ}$. Automatic semiquantitative analysis based on RIR (Reference Intensity Ratio) method was performed using PDXL software to determine the approximate amount of this phase. It was found that $99.8 \mathrm{wt}$ pct of the product is wustite.

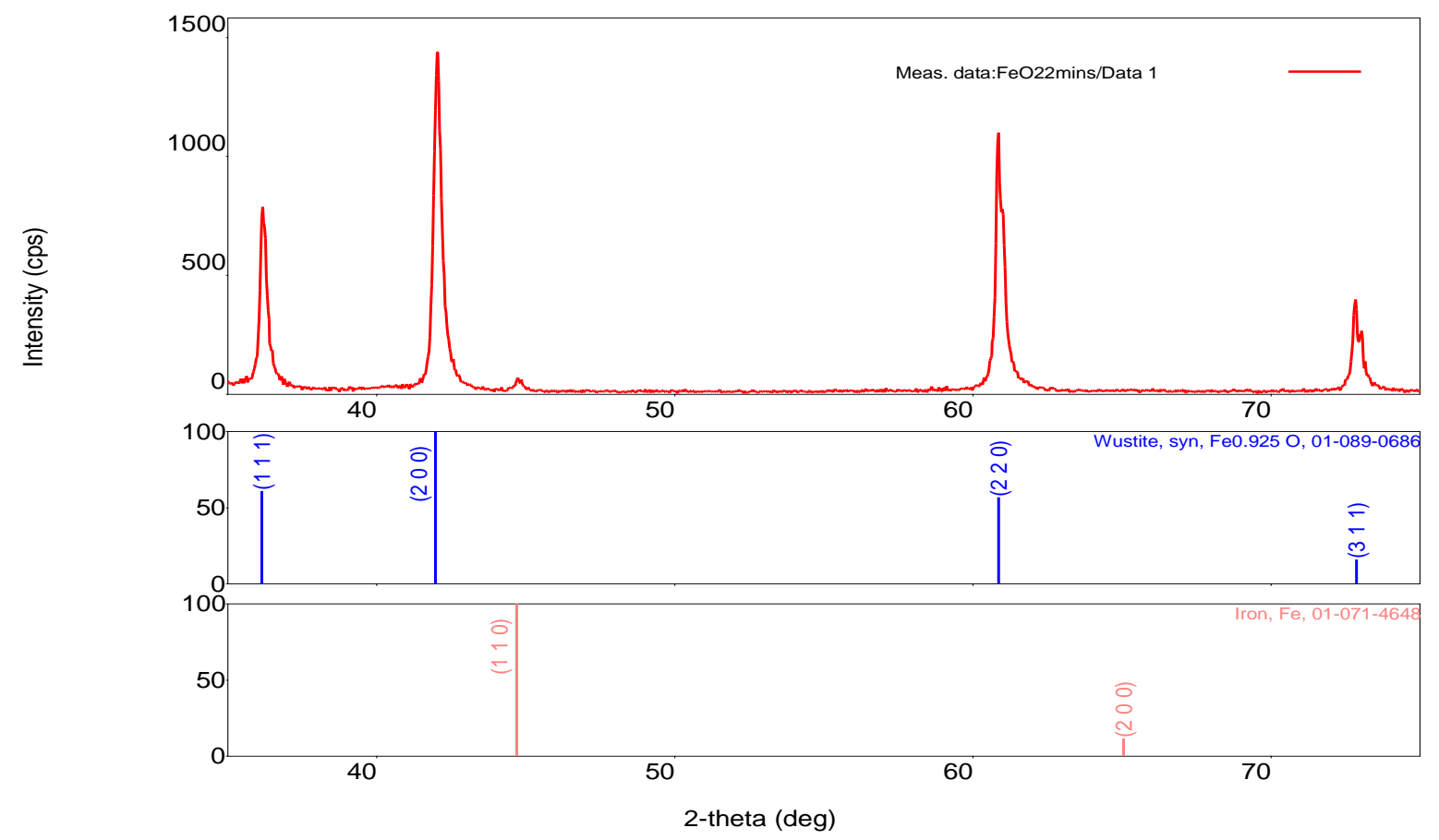

Figure 4-19: Diffraction pattern of synthetic wustite

\subsubsection{Phosphorus distribution ratio between red mud based fluxes and hot metal}

\subsubsection{Principles of Calculation}

The phosphorus distribution was measured by analyzing the flux, $(\% \mathrm{P})$, and iron foil, $[\% \mathrm{P}]^{\mathrm{Fe}-\gamma}$.

$\mathrm{L}_{\mathrm{P}}^{\mathrm{Fe}-\gamma}=\frac{(\% \mathrm{P})}{[\% \mathrm{P}]^{\mathrm{Fe}-\gamma}}$

Im et al. [107] reported that in dilute solution of phosphorus and temperature of $1300{ }^{\circ} \mathrm{C}$ the equilibrium between carbon saturated iron and solid iron dictates the following distribution of P: 
$\frac{[\% \mathrm{P}]^{\mathrm{Fe}-\gamma}}{[\% \mathrm{P}]^{\mathrm{Fe}-\mathrm{C}}}=0.413$

Consequently, the phosphorus distribution between red mud based fluxes and carbon saturated iron can be obtained as follows:

$\mathrm{L}_{\mathrm{P}}^{\mathrm{Fe}-\mathrm{C}}=\frac{(\% \mathrm{P})}{[\% \mathrm{P}]^{\mathrm{Fe}-\mathrm{C}}}=\mathrm{L}_{\mathrm{P}}^{\mathrm{Fe}-\gamma} \cdot \frac{[\% \mathrm{P}]^{\mathrm{Fe}-\gamma}}{[\% \mathrm{P}]^{\mathrm{Fe}-\mathrm{C}}}=\mathrm{L}_{\mathrm{P}}^{\mathrm{Fe}-\gamma} \times 0.413$

4-17

Details of the method of calculation of phosphorus partition ratio are provided in Appendix 5.

\subsubsection{Equilibrium time}

Preliminary experiments were performed to determine the time required to reach equilibrium. A range of dwelling time from 10 to $35 \mathrm{hrs}$ was applied to similar samples at $1350{ }^{\circ} \mathrm{C}$. Table $4-9$ shows the variation with time of phosphorus distribution in carbon saturated iron for flux composition SRM-3. As seen in Figure 4-5, the phosphorus distribution reaches a steady state value, here defined as equilibrium holding time after $\sim 30$ hours. Therefore, for subsequent experiments the holding time was set to $35 \mathrm{~h}$ to ensure equilibrium is reached under various conditions for all fluxes in Table 4-11.

Table 4-9: Results of the equilibrium time study

\begin{tabular}{cccccc}
\hline Flux & $\begin{array}{c}\text { Temperature } \\
\left({ }^{\circ} \mathrm{C}\right)\end{array}$ & Time $(\mathrm{h})$ & {$[\mathrm{P}], \mathrm{wt} . \%$} & $(\mathrm{P}), \mathrm{wt} . \%$ & $\mathrm{~L}_{\mathrm{P}}$ \\
\hline SRM-3 & 1350 & 10 & 0.003 & 5.56 & 765 \\
SRM-3 & 1350 & 15 & 0.006 & 5.53 & 380 \\
SRM-3 & 1350 & 25 & 0.007 & 5.09 & 300 \\
SRM-3 & 1350 & 30 & 0.008 & 5.29 & 272 \\
SRM-3 & 1350 & 35 & 0.006 & 4.21 & 271 \\
\hline
\end{tabular}




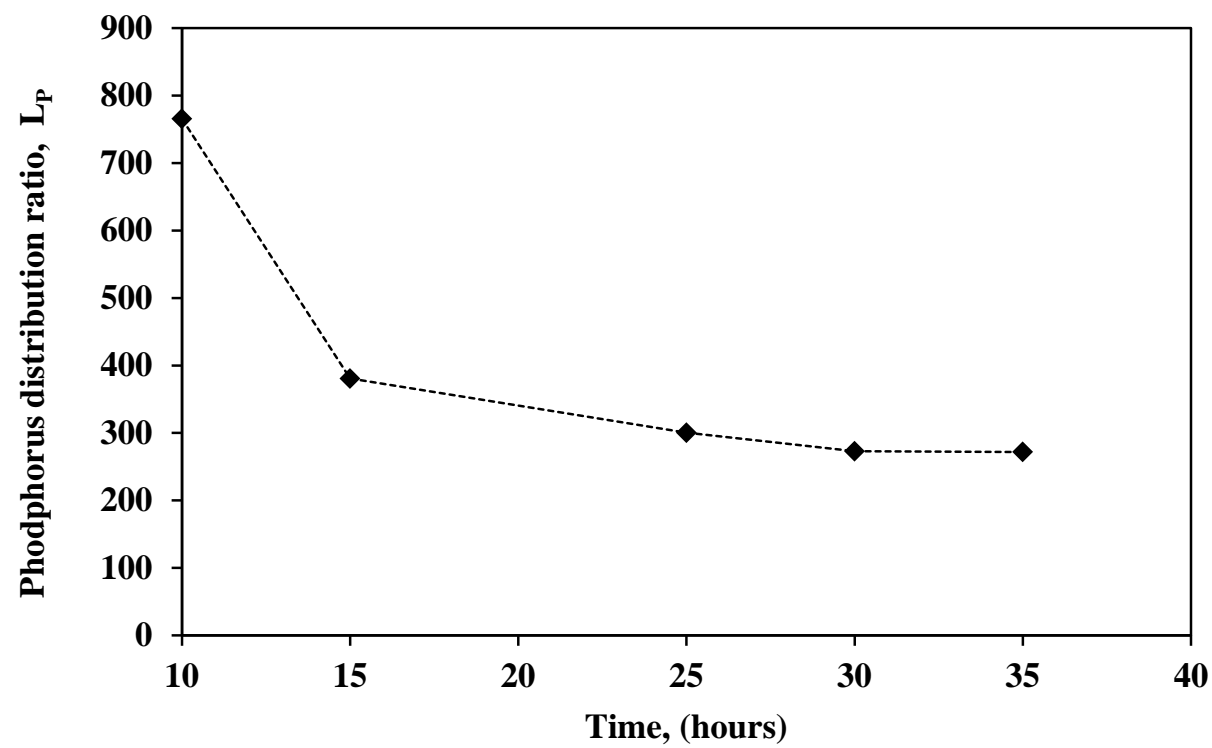

Figure 4-20: Time required to reach equilibrium at $1350{ }^{\circ} \mathrm{C}$

\subsubsection{Phosphate capacity of red mud based fluxes}

A convenient measure for comparing dephosphorization properties of different fluxes is phosphate capacity as mentioned previously in Chapter 2 . The phosphate capacity of the slags used in this study was calculated using Equation 2-56 and can be expressed as a function of temperature, distribution ratio, oxygen potential, and activity coefficient of phosphorus as follows:

$$
\log \mathrm{C}_{\mathrm{PO}_{4}^{3-}}=\log \mathrm{L}_{\mathrm{P}}-\log \mathrm{f}_{\mathrm{P}}-\frac{5}{4} \log \mathrm{P}_{O_{2}}+\frac{6392}{\mathrm{~T}}+1.475
$$

where $L_{P}$ can be obtained from the slag-metal equilibrium results (experimental) and the oxygen partial pressure is calculated from iron oxide activity data by considering the reaction of $\gamma-\mathrm{Fe}$ (gamma iron) and liquid iron oxide as follows:

$$
\begin{aligned}
& \mathrm{Fe}_{(\mathrm{S})}+\frac{1}{2} \mathrm{O}_{2}=\mathrm{FeO}_{(\mathrm{L})} \\
& \frac{1}{2} \log \mathrm{P}_{\mathrm{O}_{2}}=\log \mathrm{a}_{\mathrm{FeO}}-\log \mathrm{F}_{\mathrm{Fe}}+\frac{\Delta \mathrm{G}}{19.44 \times \mathrm{T}}
\end{aligned}
$$

where $a_{F e}=1$ for the pure solid iron strip. 
The Gibbs free energy of formation of $\mathrm{FeO}$, which was extracted from FactSage®, thermodynamic database for different temperatures is provided in Table 4-10.

Table 4-10: Estimated energy of formation of FeO from FactSage

\begin{tabular}{|c|c|}
\hline Temperature, ${ }^{\circ} \mathrm{C}$ & $\Delta \mathrm{G}^{\mathrm{o}} \mathrm{J} / \mathrm{mol}$ \\
\hline 1300 & -161653 \\
\hline 1350 & -159442 \\
\hline 1400 & -157245 \\
\hline
\end{tabular}

Activity of $\mathrm{FeO}$ was also calculated using appropriate slag models of FactSage ${ }^{\circ}$

The activity coefficient of phosphorus was calculated using interaction parameters, considering a binary Fe-P alloy as following.

$\log \mathrm{f}_{\mathrm{P}}=\mathrm{e}_{\mathrm{P}}^{\mathrm{P}} \cdot \mathrm{wt} \% \mathrm{P} \quad e_{\mathrm{P}}^{P}=0.062[104]$

\subsubsection{Dephosphorization results and discussion}

Table 4-11 shows the composition of each flux after equilibrium and phosphorus content in iron strip, along with the measured phosphorus distribution ratio between synthetic red mud flux and iron strip and the calculated ratio for hot metal. In addition, the calculated phosphate capacity and optical basicity values in the temperature range of $1300-1400{ }^{\circ} \mathrm{C}$ are listed in Table $4-11$. The final flux composition is comparable with the original blend, except $\mathrm{Na}_{2} \mathrm{O}$ content that has dropped noticeably. 
Table 4-11: Experimental results of phosphorus equilibrium between synthetic red mud flux and pure iron

\begin{tabular}{|c|c|c|c|c|c|c|c|c|c|c|c|c|c|c|c|}
\hline \multirow{2}{*}{ Heat No. } & \multirow{2}{*}{$\mathrm{T}^{\circ} \mathrm{C}$} & \multicolumn{7}{|c|}{ Flux compositions in after equilibrium (wt $\%$ ) } & \multirow{2}{*}{$\begin{array}{c}(\% \mathrm{P}) \\
(\mathrm{wt} \%)\end{array}$} & \multirow{2}{*}{$\begin{array}{r}{[\% \mathrm{P}]} \\
(\mathrm{wt} \%)\end{array}$} & \multirow{2}{*}{$\mathrm{OB}$} & \multirow{2}{*}{$\mathrm{L}_{\mathrm{p}}^{\mathrm{Fe}-\mathrm{\gamma}}$} & \multirow{2}{*}{$\mathrm{L}_{\mathrm{P}}^{\mathrm{Fe}-\mathrm{C}}$} & \multirow{2}{*}{$a_{\mathrm{FeO}}$} & \multirow{2}{*}{$\log \mathrm{C}_{\mathrm{PO}_{4}^{3-}}$} \\
\hline & & $\mathrm{CaO}$ & $\mathrm{Al}_{2} \mathrm{O}_{3}$ & $\mathrm{SiO}_{2}$ & $\mathrm{P}_{2} \mathrm{O}_{5}$ & $\mathrm{FeO}$ & $\mathrm{TiO}_{2}$ & $\mathrm{Na}_{2} \mathrm{O}$ & & & & & & & \\
\hline SRM-1 & 1300 & 8.77 & 17.03 & 9.19 & 9.89 & 42.42 & 7.95 & 4.76 & 4.30 & 0.022 & 0.71 & 199.02 & 82.20 & 0.79 & 21.31 \\
\hline SRM-2 & 1300 & 14.92 & 15.20 & 7.88 & 11.64 & 38.54 & 6.34 & 4.48 & 5.06 & 0.022 & 0.71 & 234.30 & 96.76 & 0.68 & 21.54 \\
\hline SRM-3 & 1300 & 24.08 & 14.13 & 6.73 & 12.31 & 33.50 & 5.19 & 4.07 & 5.35 & 0.020 & 0.73 & 270.25 & 111.61 & 0.54 & 21.84 \\
\hline SRM-4 & 1300 & 31.59 & 10.59 & 6.26 & 11.51 & 31.49 & 5.31 & 3.26 & 5.00 & 0.018 & 0.75 & 277.93 & 114.78 & 0.39 & 22.22 \\
\hline SRM-5 & 1300 & 39.39 & 8.98 & 6.10 & 10.84 & 26.67 & 4.77 & 3.25 & 4.72 & 0.016 & 0.77 & 291.05 & 120.20 & 0.27 & 65 \\
\hline SRM-6 & 1300 & 47.08 & 8.15 & 5.26 & 10.77 & 21.34 & 4.09 & 2.32 & 4.68 & 0.018 & 0.78 & 260.03 & 107.39 & 0.24 & 22.71 \\
\hline SRM-7 & 1300 & 39.12 & 15.10 & 5.13 & 10.27 & 23.39 & 4.62 & 2.37 & 4.46 & 0.021 & 0.76 & 215.68 & 89.08 & 0.24 & 22.61 \\
\hline SRM-8 & 1300 & 38.59 & 19.29 & 5.08 & 10.69 & 22.35 & 3.02 & 1.97 & 4.65 & 23 & 0.76 & 202.14 & 83.48 & 0.26 & 2.51 \\
\hline SRM-9 & 1300 & 36.37 & 22.95 & 4.98 & 9.55 & 21.51 & 2.77 & 1.88 & 4.15 & 0.023 & 0.75 & 180.46 & 74.53 & 0.39 & 22.04 \\
\hline SRM-10 & 1300 & 36.56 & 24.03 & 3.76 & 9.65 & 20.27 & 3.11 & 2.62 & 4.20 & 0.023 & 0.75 & 182.45 & 75.35 & 0.36 & 22.13 \\
\hline SRM-11 & 1300 & 39.51 & 8.12 & 5.15 & 11.40 & 25.71 & 6.90 & 3.22 & 4.95 & 0.018 & 0.77 & 275.27 & 113.69 & 0.25 & 22.68 \\
\hline SRM-12 & 1300 & 38.09 & 7.80 & 4.10 & 11.47 & 26.67 & 9.73 & 2.13 & 4.99 & 0.018 & 0.76 & 277.01 & 114.41 & 0.27 & 22.60 \\
\hline SRM-13 & 1300 & 38.39 & 8.46 & 5.43 & 10.90 & 23.49 & 11.04 & 2.30 & 4.74 & 0.024 & 0.76 & 197.38 & 81.52 & 0.26 & 22.51 \\
\hline SRM-14 & 1300 & 37.90 & 6.21 & 4.22 & 9.97 & 24.93 & 14.00 & 2.77 & 4.33 & 0.024 & 0.77 & 180.62 & 74.60 & 0.28 & 22.41 \\
\hline SRM-15 & 1300 & 39.97 & 6.29 & 11.11 & 10.78 & 24.08 & 3.55 & 2.21 & 4.69 & 0.023 & 0.74 & 208.31 & 86.03 & 0.27 & 22.48 \\
\hline SRM-16 & 1300 & 38.93 & 7.57 & 13.33 & 10.62 & 22.52 & 3.19 & 2.83 & 4.62 & 0.025 & 0.73 & 184.74 & 76.30 & 0.38 & 22.06 \\
\hline SRM-17 & 1300 & 37.98 & 5.94 & 18.62 & 11.22 & 21.25 & 2.86 & 2.14 & 4.88 & 0.028 & 0.71 & 177.35 & 73.25 & 0.56 & 21.63 \\
\hline
\end{tabular}




\begin{tabular}{|c|c|c|c|c|c|c|c|c|c|c|c|c|c|c|c|}
\hline SRM-18 & 1300 & 37.13 & 6.07 & 21.50 & 10.42 & 20.20 & 3.51 & 1.17 & 4.53 & 0.030 & 0.70 & 151.06 & 62.39 & 0.52 & 21.64 \\
\hline SRM-1 & 1350 & 7.79 & 18.78 & 7.01 & 10.51 & 43.67 & 8.27 & 3.97 & 4.57 & 0.025 & 0.71 & 180.12 & 74.39 & 0.69 & 20.87 \\
\hline SRM-2 & 1350 & 15.95 & 16.58 & 6.06 & 11.33 & 38.54 & 7.28 & 4.27 & 4.94 & 0.022 & 0.72 & 224.73 & 92.81 & 0.62 & 21.09 \\
\hline SRM-3 & 1350 & 24.23 & 14.50 & 6.15 & 11.70 & 33.71 & 5.80 & 3.89 & 5.10 & 0.020 & 0.73 & 257.13 & 106.20 & 0.53 & 21.31 \\
\hline SRM-4 & 1350 & 31.91 & 12.43 & 6.43 & 11.50 & 28.90 & 5.12 & 3.71 & 5.01 & 0.018 & 0.75 & 284.86 & 117.65 & 0.41 & 21.64 \\
\hline SRM-5 & 1350 & 41.18 & 10.45 & 6.51 & 9.66 & 24.30 & 4.80 & 3.10 & 4.21 & 0.015 & 0.77 & 273.55 & 112.97 & 0.23 & 22.23 \\
\hline SRM-6 & 1350 & 49.40 & 8.59 & 5.00 & 10.04 & 19.97 & 4.20 & 2.79 & 4.38 & 0.018 & 0.79 & 241.13 & 99.59 & 0.22 & 22.24 \\
\hline SRM-7 & 1350 & 39.60 & 13.71 & 5.06 & 11.87 & 22.39 & 3.68 & 1.69 & 5.18 & 0.024 & 0.74 & 215.43 & 88.97 & 0.22 & 22.22 \\
\hline SRM-8 & 1350 & 38.89 & 15.27 & 5.75 & 10.27 & 22.39 & 3.31 & 2.13 & 4.48 & 0.024 & 0.74 & 186.49 & 77.02 & 0.23 & 22.10 \\
\hline SRM-9 & 1350 & 38.65 & 17.90 & 4.95 & 11.82 & 21.20 & 3.34 & 2.15 & 5.15 & 0.029 & 0.75 & 179.90 & 74.30 & 0.24 & 22.02 \\
\hline SRM-10 & 1350 & 37.18 & 22.27 & 4.92 & 11.30 & 19.22 & 3.36 & 1.75 & 4.93 & 0.031 & 0.74 & 160.77 & 66.40 & 0.32 & 21.66 \\
\hline SRM-11 & 1350 & 39.16 & 10.04 & 5.46 & 11.39 & 23.73 & 8.04 & 2.17 & 4.97 & 0.020 & 0.75 & 243.10 & 100.40 & 0.23 & 22.20 \\
\hline SRM-12 & 1350 & 40.11 & 9.11 & 4.46 & 11.22 & 23.83 & 9.38 & 1.89 & 4.89 & 0.024 & 0.76 & 207.91 & 85.87 & 0.24 & 22.08 \\
\hline SRM-13 & 1350 & 39.22 & 7.99 & 5.42 & 11.13 & 23.70 & 11.49 & 1.06 & 4.85 & 0.024 & 0.75 & 202.11 & 83.47 & 0.25 & 22.03 \\
\hline SRM-14 & 1350 & 38.71 & 7.62 & 4.16 & 9.95 & 22.74 & 14.76 & 2.05 & 4.34 & 0.026 & 0.76 & 166.23 & 68.65 & 0.25 & 21.96 \\
\hline SRM-15 & 1350 & 40.01 & 9.42 & 13.10 & 10.59 & 22.30 & 2.15 & 2.42 & 4.62 & 0.026 & 0.74 & 175.51 & 72.48 & 0.35 & 21.61 \\
\hline SRM-16 & 1350 & 37.69 & 9.33 & 16.02 & 10.13 & 21.12 & 2.85 & 2.86 & 4.42 & 0.027 & 0.72 & 165.83 & 68.49 & 0.47 & 21.25 \\
\hline SRM-17 & 1350 & 38.64 & 8.47 & 19.15 & 9.47 & 19.55 & 2.89 & 1.84 & 4.13 & 0.031 & 0.71 & 134.09 & 55.38 & 0.48 & 21.14 \\
\hline SRM-18 & 1350 & 37.85 & 7.70 & 21.50 & 10.00 & 19.82 & 2.78 & 1.35 & 4.36 & 0.036 & 0.70 & 121.73 & 50.28 & 0.50 & 21.06 \\
\hline SRM-1 & 1400 & 8.86 & 17.62 & 11.67 & 9.69 & 41.96 & 6.42 & 3.78 & 4.21 & 0.023 & 0.70 & 184.86 & 76.35 & 0.849 & 20.16 \\
\hline
\end{tabular}




\begin{tabular}{|c|c|c|c|c|c|c|c|c|c|c|c|c|c|c|c|}
\hline SRM-2 & 400 & 15.19 & 16.50 & 7.53 & 10.53 & 40.35 & 6.46 & 3.43 & 4.59 & 0.025 & 0.72 & 185.89 & 76.77 & 0.645 & 20.46 \\
\hline SRM-3 & 1400 & 23.62 & 14.99 & 7.19 & 10.78 & 34.80 & 5.50 & 3.11 & 4.70 & 021 & .73 & 224.95 & 2.90 & .555 & 20.71 \\
\hline SRM-4 & 1400 & 32.15 & 10.68 & 6.12 & 11.17 & 31.81 & 5.18 & 2.89 & 4.87 & 0.019 & .75 & 256.35 & 105.87 & 0.37 & 21.20 \\
\hline SRM-5 & 1400 & 41.99 & 8.00 & 6.40 & 11.04 & 25.28 & 4.92 & 2.37 & 4.81 & 0.019 & 0.77 & 253.23 & 104.59 & 0.229 & 21.72 \\
\hline SRM-6 & 1400 & 49.32 & 8.01 & 3.54 & 11.05 & 21.76 & 3.37 & 2.96 & 4.82 & 0.023 & 0.80 & 211.27 & 87.25 & 0.216 & 21.70 \\
\hline SRM-7 & 1400 & 40.66 & 12.51 & 6.44 & 10.05 & 23.93 & 3.59 & 2.82 & 4.38 & 0.024 & 0.77 & 180.30 & 74.46 & 0.214 & 21.65 \\
\hline SRM-8 & 1400 & 39.24 & 16.32 & 5.19 & 10.30 & 23.32 & 2.85 & 2.78 & 4.49 & 0.027 & 0.76 & 166.40 & 68.72 & 0.209 & 21.64 \\
\hline SRM-9 & 1400 & 37.89 & 19.34 & 4.68 & 9.79 & 22.66 & 3.72 & 1.93 & 4.27 & 0.024 & 0.75 & 175.57 & 72.51 & 0.257 & 21.43 \\
\hline SRM-10 & 1400 & 37.55 & 23.15 & 3.62 & 10.24 & 20.85 & 2.66 & 1.94 & 4.46 & 0.030 & 0.75 & 150.26 & 62.06 & 0.258 & 21.36 \\
\hline SRM-11 & 1400 & 40.79 & 9.98 & 5.83 & 10.50 & 22.84 & 8.16 & 1.91 & 4.58 & 0.027 & 0.76 & 171.39 & 70.78 & 0.214 & 21.62 \\
\hline SRM-12 & 1400 & 39.53 & 9.22 & 4.78 & 10.66 & 22.45 & 10.77 & 2.60 & 4.65 & 0.030 & 0.76 & 154.91 & 63.98 & 0.214 & 21.58 \\
\hline SRM-13 & 1400 & 37.80 & 8.76 & 4.99 & 9.65 & 23.04 & 13.82 & 1.94 & 4.21 & 0.030 & 0.76 & 140.25 & 57.92 & 0.263 & 21.31 \\
\hline SRM-14 & 1400 & 39.43 & 7.60 & 4.35 & 8.81 & 21.39 & 16.47 & 1.97 & 3.84 & 0.039 & 0.77 & 98.47 & 40.67 & 0.23 & 21.30 \\
\hline SRM-15 & 1400 & 40.60 & 8.94 & 12.05 & 10.07 & 22.55 & 3.80 & 1.98 & 4.39 & 0.027 & 0.74 & 162.58 & 67.15 & 0.308 & 21.20 \\
\hline SRM-16 & 1400 & 39.76 & 7.50 & 14.61 & 10.33 & 22.28 & 3.79 & 1.73 & 4.50 & 0.030 & 0.73 & 150.09 & 61.99 & 0.373 & 20.96 \\
\hline SRM-17 & 1400 & 37.83 & 8.34 & 17.62 & 9.28 & 22.29 & 3.02 & 1.62 & 4.04 & 0.033 & 0.72 & 122.57 & 50.62 & 0.499 & 20.56 \\
\hline SRM-18 & 1400 & 38.31 & 7.10 & 19.80 & 9.96 & 20.12 & 3.72 & 0.98 & 4.34 & 0.036 & 0.71 & 120.65 & 49.83 & 0.469 & 20.62 \\
\hline
\end{tabular}




\subsubsection{Effect of iron oxide on the phosphorus distribution ratio and phosphate capacity}

The effect of iron oxide content on the phosphorus distribution ratio and the phosphate capacity of the synthetic red mud based fluxes (SRM-1 through SRM-6) at different temperatures from 1300 to $1400{ }^{\circ} \mathrm{C}$ are plotted in Figure 4-21 and Figure 4-23.It can be seen that the phosphorus distribution ratio first increases with increasing iron oxide concentration to reach a maximum around 30 wt pet $\mathrm{FeO}$ and then drops. In term of repeatability of the experiments samples (SRM-1 through SRM-6) were chosen to repeat the experiment three times at $1400{ }^{\circ} \mathrm{C}$. The resulting experiments had a standard deviation approximately ${ }_{ \pm} 7 \%$ of the calculated phosphorus distribution ratios at $1400{ }^{\circ} \mathrm{C}$ for each sample.

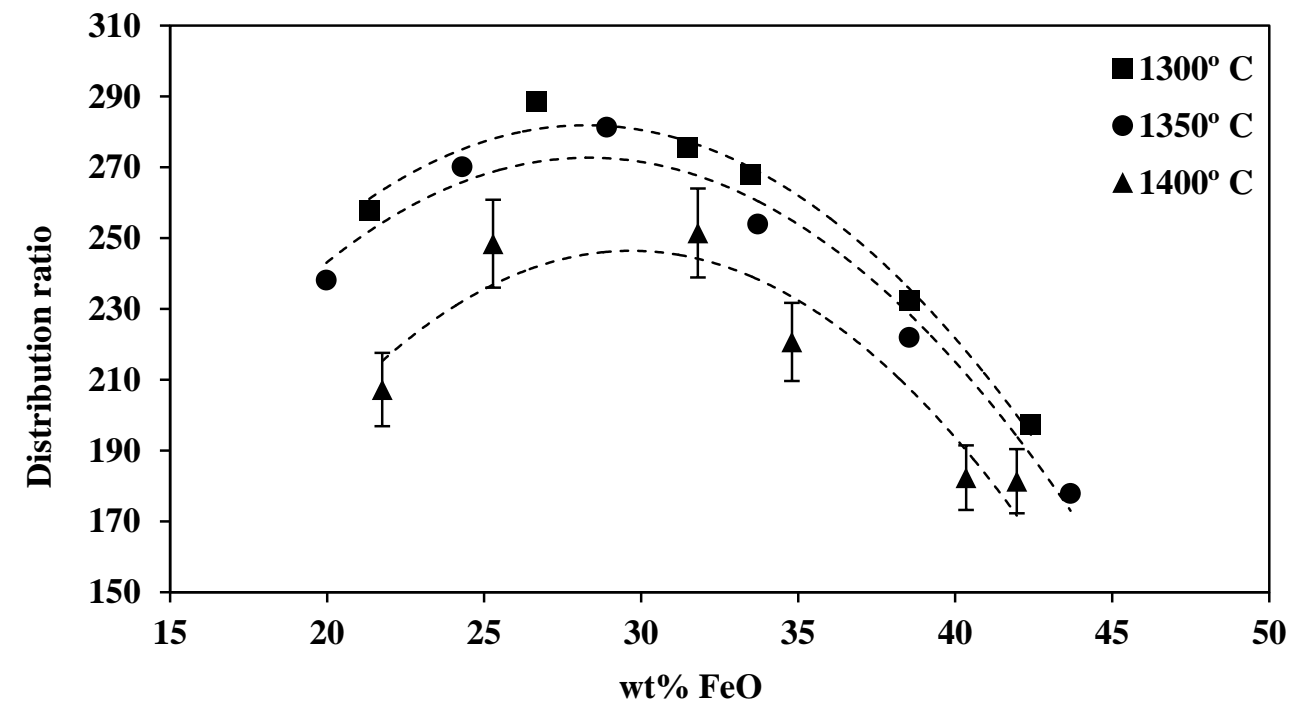

Figure 4-21: Effect of iron oxide content on the phosphorus distribution ratio $\left(\mathrm{L}_{\mathrm{P}}^{\mathrm{Fe}-\mathrm{C}}\right)$ Error bars were determined for $1400^{\circ} \mathrm{C}$ only.

The results show similar variation in the temperature range of $1300{ }^{\circ} \mathrm{C}-1400{ }^{\circ} \mathrm{C}$. The maximum distribution ratios are $\mathrm{L}_{\mathrm{P}}{ }^{\mathrm{Fe}-\mathrm{C}}=288, \mathrm{~L}_{\mathrm{P}}^{\mathrm{Fe}-\mathrm{C}}=281$ and $\mathrm{L}_{\mathrm{P}}^{\mathrm{Fe}-\mathrm{C}}=251$ corresponding to $26.6 \mathrm{wt} \%$, $28.9 \mathrm{wt} \%$ and $31.8 \mathrm{wt} \%$ iron oxide at $1300{ }^{\circ} \mathrm{C}, 1350{ }^{\circ} \mathrm{C}$ and $1400{ }^{\circ} \mathrm{C}$ respectively.

Mohassab et al.[108] reported the same tendency between $\mathrm{FeO}$ concentration and phosphorus distribution, Figure 4-22. As seen, $\mathrm{L}_{\mathrm{P}}$ increases with $\mathrm{FeO}$ content up to 20-30 wt pct, and then begins to decrease as $\mathrm{FeO}$ content is raised. They attributed this trend to the variation of the 
activity coefficient of $\mathrm{P}_{2} \mathrm{O}_{5}\left(\gamma_{P_{2} O_{5}}\right)$ with $\mathrm{FeO}$ content; $\gamma_{P_{2} O_{5}}$ was decreased with increasing $\mathrm{FeO}$ when $\mathrm{FeO}<20-30$ wt $\%$ and increased afterwards.

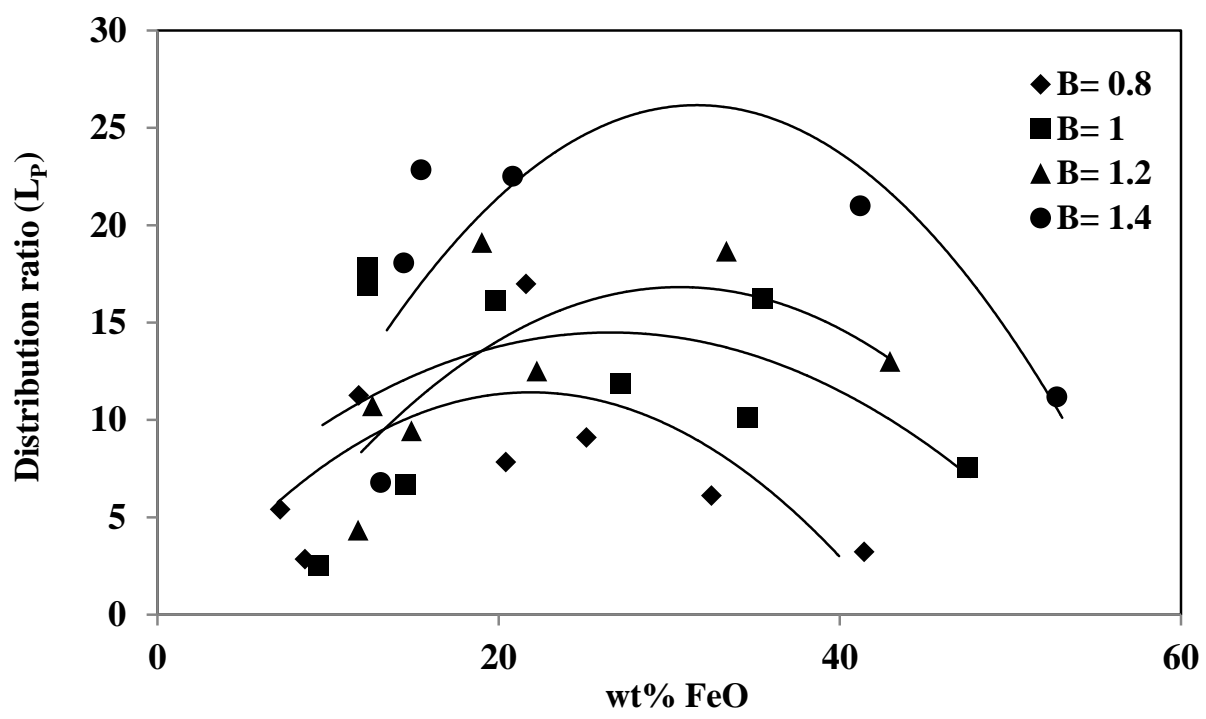

Figure 4-22: Effect of FeO content on $\mathrm{L}_{\mathrm{P}}$ at different basicity [108]

Figure 4-23 shows the effect of FeO content on the phosphate capacity. It can be seen that $\log \mathrm{C}_{\mathrm{PO}_{4}^{3-}}$ increases when the $\mathrm{FeO}$ concentration decreases to $\sim 25-28 \mathrm{wt}$ pct for different temperatures and then becomes more or less stable at lower FeO contents.

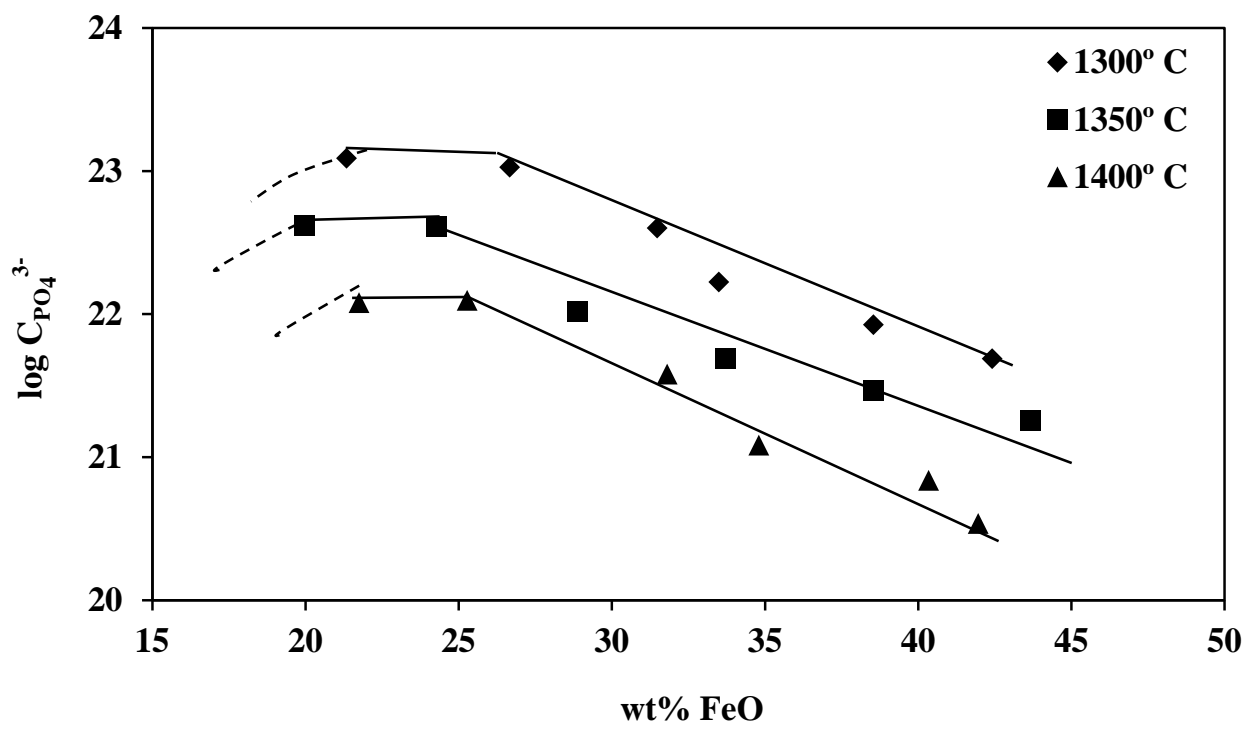

Figure 4-23: Effect of iron oxide content on the phosphate capacity 
The variations in phosphate capacity or phosphorus distribution can be explained by looking into the reaction of dephosphorization as follows:

$[\mathrm{P}]+\frac{5}{4} \mathrm{O}_{2}(\mathrm{~g})+\frac{3}{2}\left(\mathrm{O}^{2-}\right)=\left(\mathrm{PO}_{4}^{3-}\right)$

Increasing $\mathrm{FeO}$ content leads to higher $\mathrm{FeO}$ activity and consequently increases the oxygen partial pressure of the system, shifting the reaction to the right side; the effect is larger $\mathrm{P}$ incorporation in the slag phase. Even though the phosphorus removal is favored with increase in oxygen partial pressure, high iron oxide content would reduce the distribution ratio or dephosphorization capacity due to decreasing the $\mathrm{CaO}$ content or basicity.

Equation 4-22 suggests that both oxygen potential and basicity $\left(\mathrm{O}^{2-}\right)$ are desired for dephosphorization. Larger $\mathrm{FeO}$ on one hand leads to higher oxygen potential and on the other hand results in lower $\mathrm{CaO}$ concentration, hence the reduced basicity. One therefore expects that maximum $\mathrm{L}_{\mathrm{P}}$ is obtained at certain $\mathrm{FeO}$ content, as Figure 4-21 demonstrates.

Figure 4-24 compares the calculated distribution ratio in this study along with other results [85, 87]. The trend of experimental results in the present study is similar to that reported by Werme and Lundh $[85,87]$ even though the absolute values are different. In the present study iron oxide concentration higher than $44 \mathrm{wt} \%$ or below $20 \mathrm{wt} \%$ were not investigated because of the limited range of iron oxide content in the original red mud based slag. The reason for not seeing a maximum clearly in the results of this study is that lower iron oxide contents $(<20 \mathrm{wt} \%)$ would be required to drive the curve down.

Phosphorus oxidation is strongly exothermic and is favored at lower temperature. The effect of temperature on the phosphorus distribution ratio and phosphate capacity is shown in Figure 4-21 and Figure 4-23, respectively. It can be noticed that both $\mathrm{L}_{\mathrm{P}}$ and $\mathrm{C}_{\mathrm{PO}_{4}^{3-}}$ decrease with increasing temperature in the range of $1300-1400{ }^{\circ} \mathrm{C}$. This finding is consistent with the previously reported results by Mohassab et al. [108] Figure 4-25. 


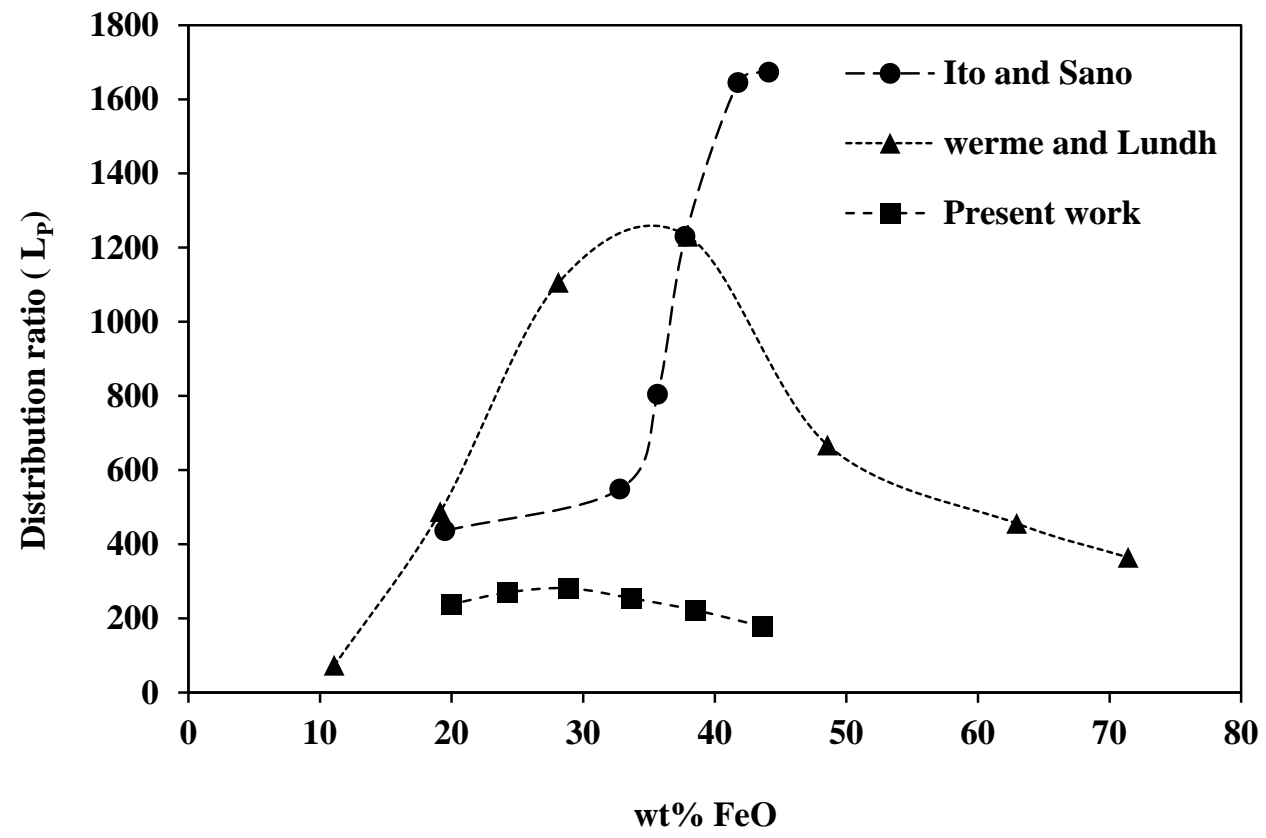

Figure 4-24: Equilibrium phosphorus distribution between various fluxes and carbon-saturated iron at $1300{ }^{\circ} \mathrm{C}$

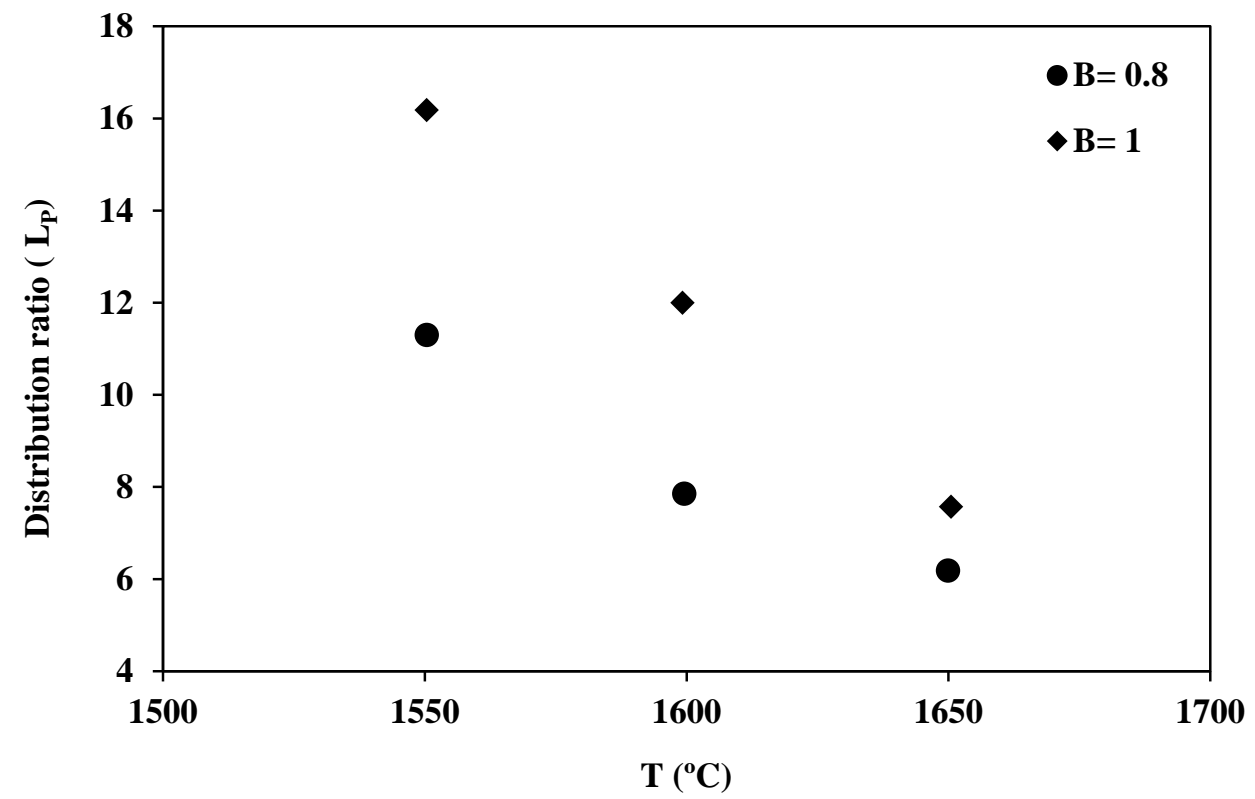

Figure 4-25: Effect of temperature on $L_{P}$ at different basicities [108] 


\subsubsection{Effect of $\mathrm{CaO}$ content on the phosphorus distribution ratio}

Lime is a very effective fluxing agent for dephosphorization of liquid iron due to the strong interaction and formation of stable compounds between the $\mathrm{CaO}$ and $\mathrm{P}_{2} \mathrm{O}_{5}$, namely $3 \mathrm{CaO} \cdot \mathrm{P}_{2} \mathrm{O}_{5}$. It is of significant interest to understand the optimum amount of lime required to make red mud an effective flux, because the initial $\mathrm{CaO}$ content of red mud is not large, and the lime addition affects the flux cost. The dependence of phosphorus distribution ratio and phosphate capacity on $\mathrm{CaO}$ content in the synthetic red mud fluxes are shown in Figure 4-26 and Figure 4-27, respectively. As seen, the phosphorus distribution ratio reaches a maximum at about $32 \mathrm{wt} \% \mathrm{CaO}$ for all temperatures. Larger $\mathrm{CaO}$ amounts show a negative impact on $\mathrm{L}_{\mathrm{P}}$. Again, it can be explained that an optimum balance of oxygen potential (determined by $\mathrm{FeO}$ activity) and basicity is required for maximum $\mathrm{L}_{\mathrm{P}}$. Clearly, the above $\mathrm{CaO}$ content is where this balance is maintained for the current fluxes.

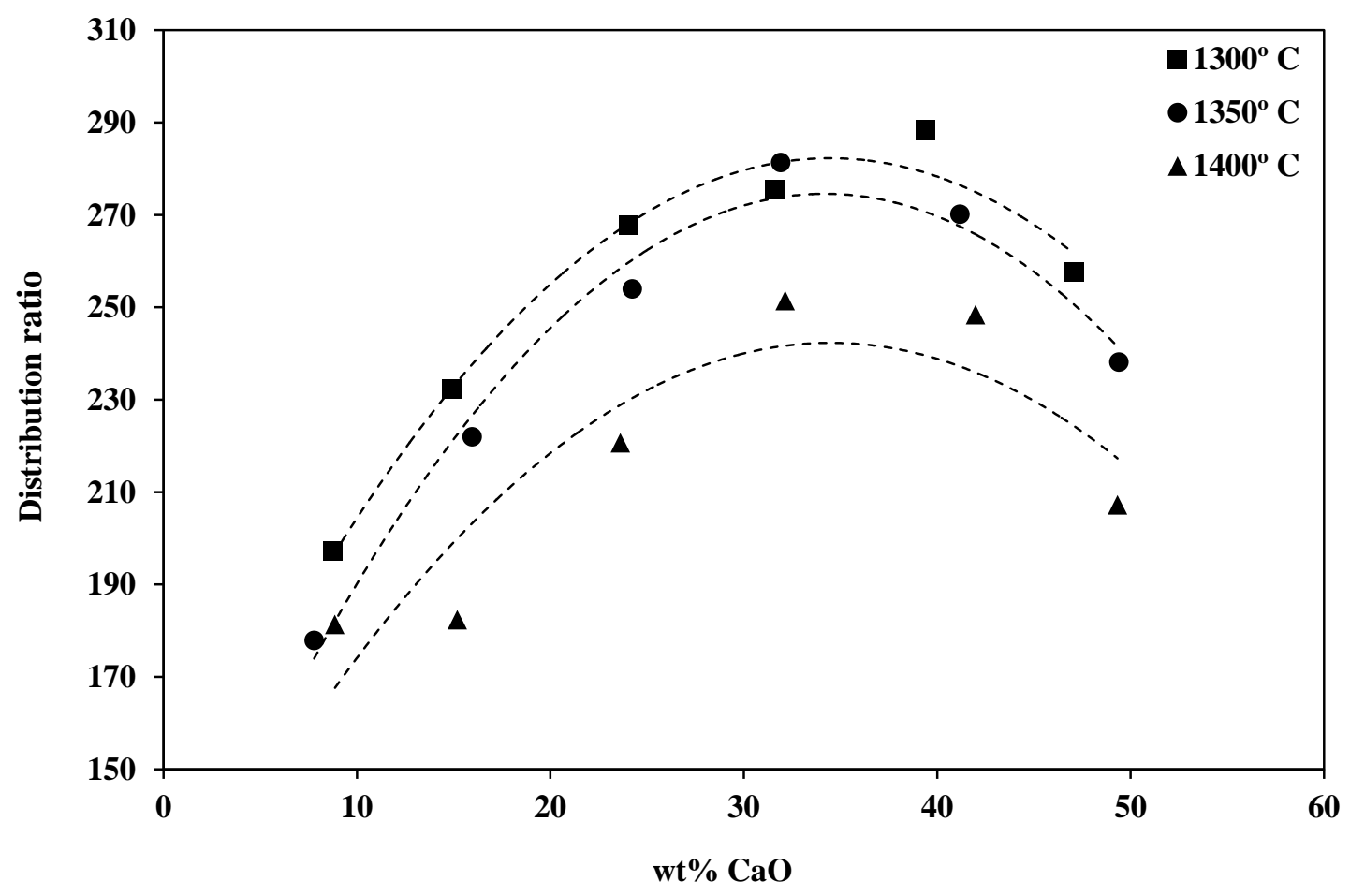

Figure 4-26: Relationship between the phosphorus distribution ratio $\left(\mathrm{L}_{\mathrm{P}}^{\mathrm{Fe}-\mathrm{C}}\right)$ and lime content 


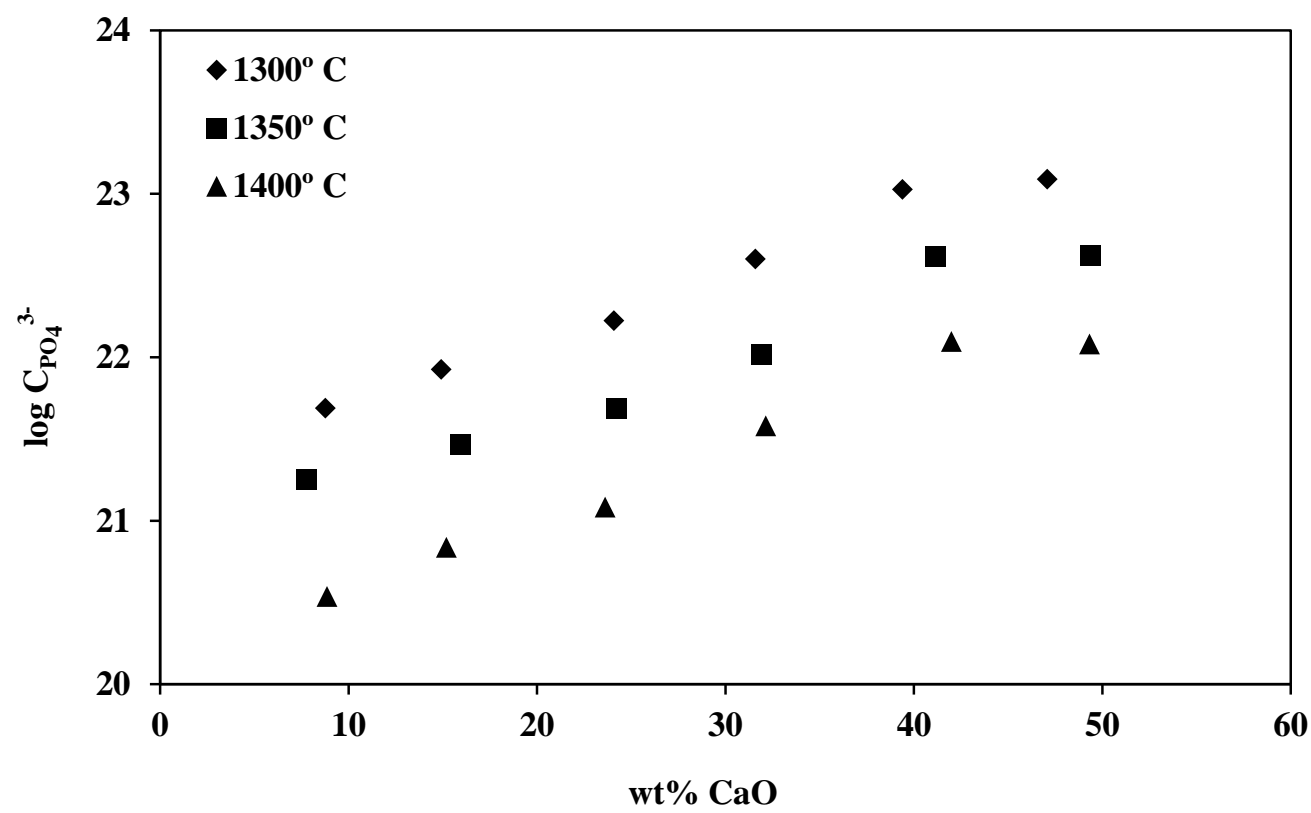

Figure 4-27: Effect of lime content on the phosphate capacity

\subsubsection{Optical basicity}

The optical basicities of synthetic red mud based fluxes were calculated using the method and values discussed earlier, Table 4-4. The results are provided in Table 4-11.

Figure 4-28 and Figure 4-29 show the relationship between the phosphorus distribution ratio and phosphate capacities with the optical basicity of synthetic red mud based fluxes (fluxes SRM-1 through SRM-6) at different temperature.

It is evident from Figure 4-28 that the phosphorus distribution ratio increased when the optical basicity was increased to $\sim 0.75$ in the temperature range of $1300{ }^{\circ} \mathrm{C}-1400{ }^{\circ} \mathrm{C}$ and decreases with further increase in the optical basicity. An increase in the basicity is generally expected to increase the phosphorus distribution ratio and phosphate capacity [31, 109], unless as stated earlier it operates against oxygen potential, which is the case here, hence a maximum in the curves.

Figure 4-30 shows the variation of the phosphate capacity with optical basicity, obtained by Yang et al. [44] along with the results of the present study. 


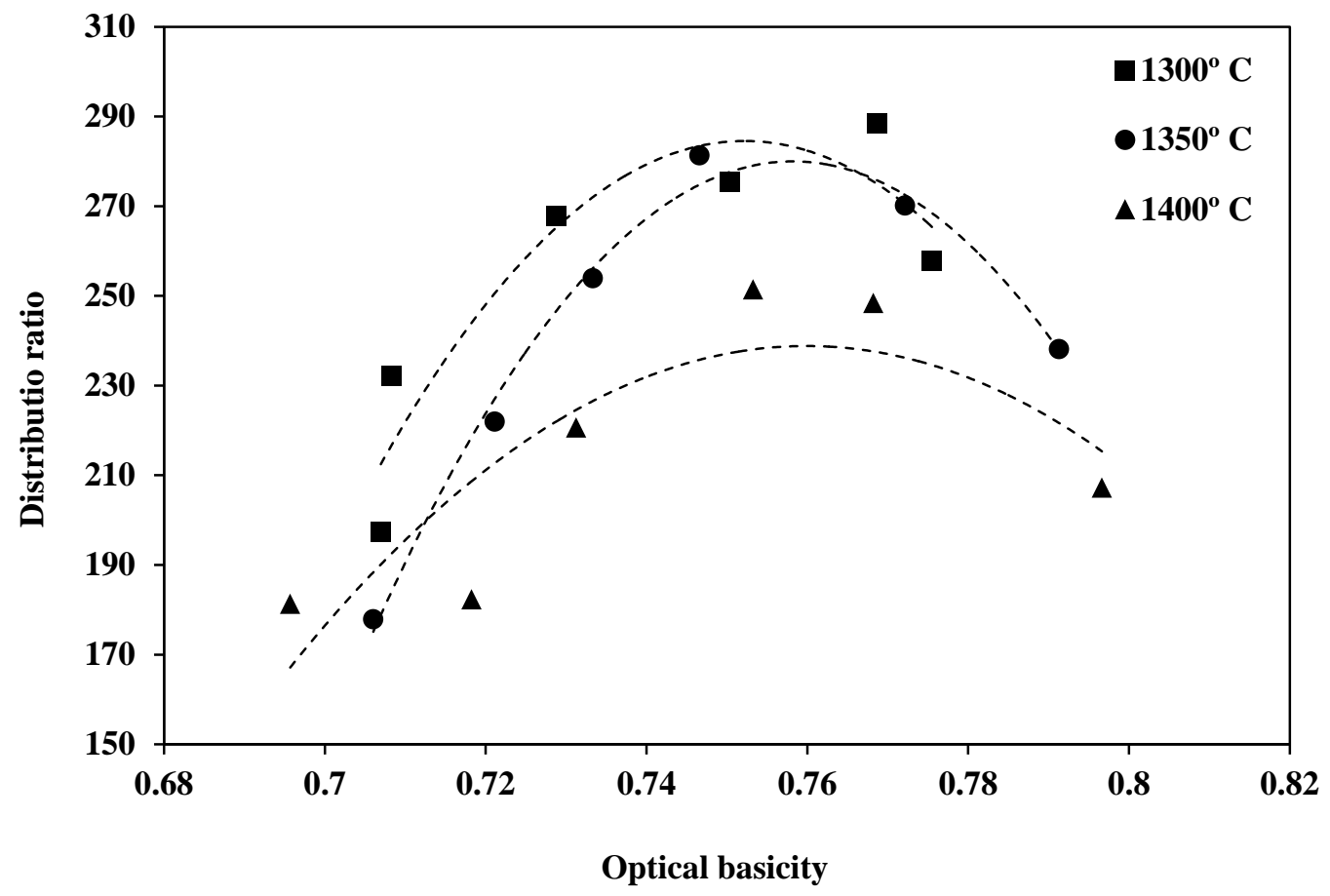

Figure 4-28: Correlation between the phosphorus distribution ratio $\left(\mathrm{L}_{\mathrm{P}}^{\mathrm{Fe}-\mathrm{C}}\right)$ and optical basicity

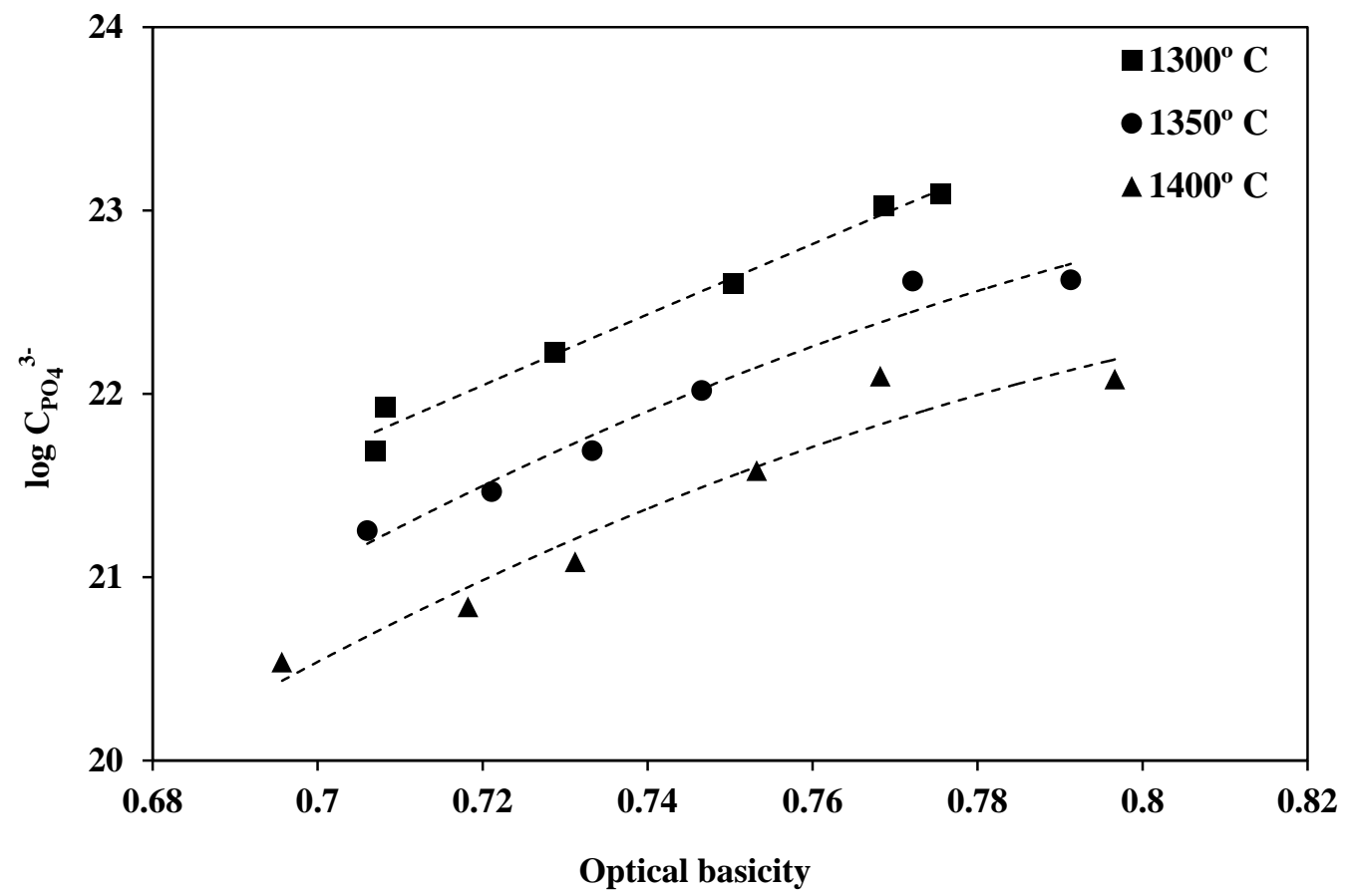

Figure 4-29: Correlation between phosphate capacity and optical basicity 


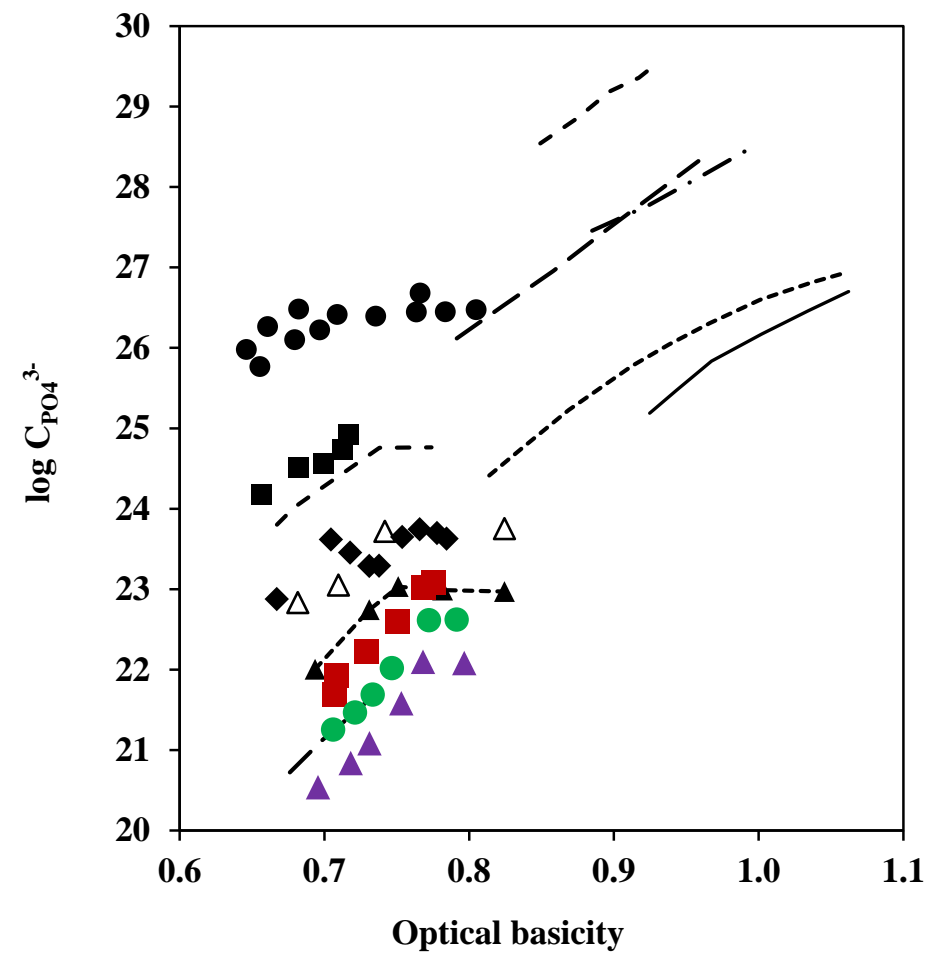

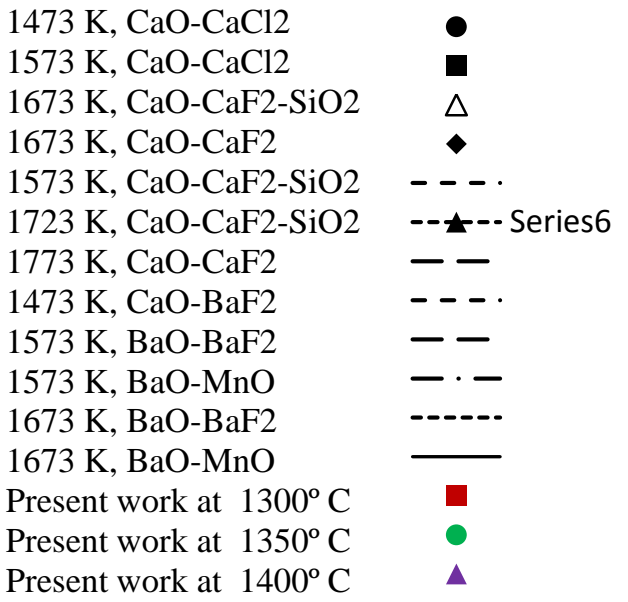

Figure 4-30: Comparison of the phosphate capacities of different slags and present study

\subsubsection{Effect of acidic oxides on the phosphorus distribution ratio and phosphate capacity of the synthetic red mud based fluxes}

The results presented earlier showed that fixed flux SRM-5 offers the highest $\mathrm{P}$ absorption when $\mathrm{FeO}$ is varied and the composition of the remaining flux is fixed. Red mud is essentially the alumina-free bauxite ore and its composition widely varies, particularly the amounts of acidic oxides $\mathrm{Al}_{2} \mathrm{O}_{3}, \mathrm{TiO}_{2}$ and $\mathrm{SiO}_{2}$. In order to investigate the effect of these oxides different amounts of each were added to flux SRM-5. Table 4-11 shows the final compositions, distribution ratio, and phosphate capacity for the new compositions (SRM-7 through SRM-18).

The obtained results are plotted versus $\mathrm{Al}_{2} \mathrm{O}_{3}$ (SRM-7 through SRM-10) and $\mathrm{TiO}_{2}$ (SRM-11 through SRM-14) content in the range of $1300{ }^{\circ} \mathrm{C}-1400^{\circ} \mathrm{C}$ in Figure 4-31 - Figure 4-34.

The results indicate that phosphorus partition ratio and phosphate capacity decrease with increasing $\mathrm{Al}_{2} \mathrm{O}_{3}$ and $\mathrm{TiO}_{2}$ contents. This is expected as addition of these oxides decreases both the basicity and oxygen potential (due to the decrease in $\mathrm{FeO}$ ). 


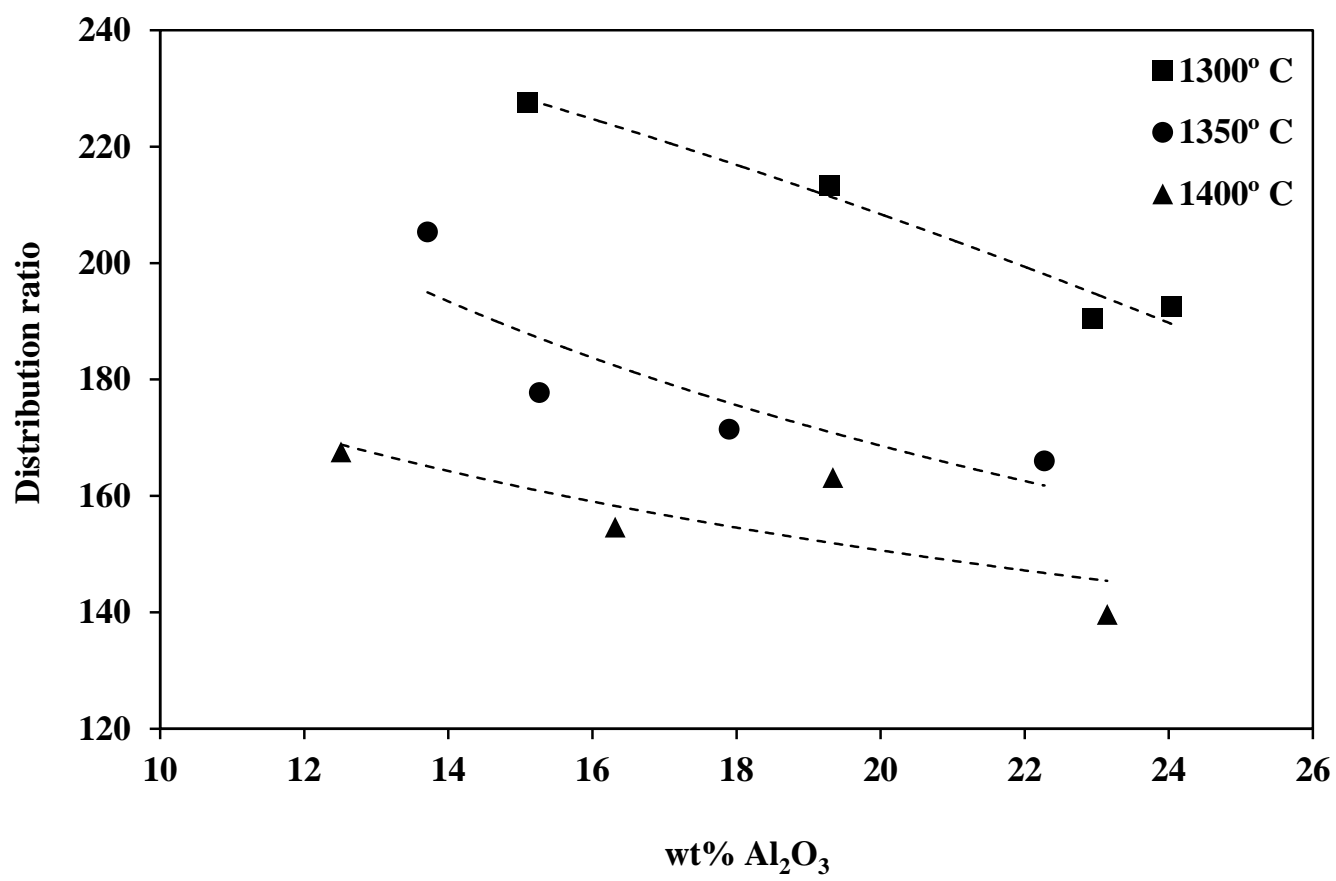

Figure 4-31: Relationship between the phosphorus distribution ratio ( $\mathrm{LP}_{\mathrm{P}}^{\mathrm{Fe}-\mathrm{C}}$ ) and wt $\% \mathrm{Al}_{2} \mathrm{O}_{3}$

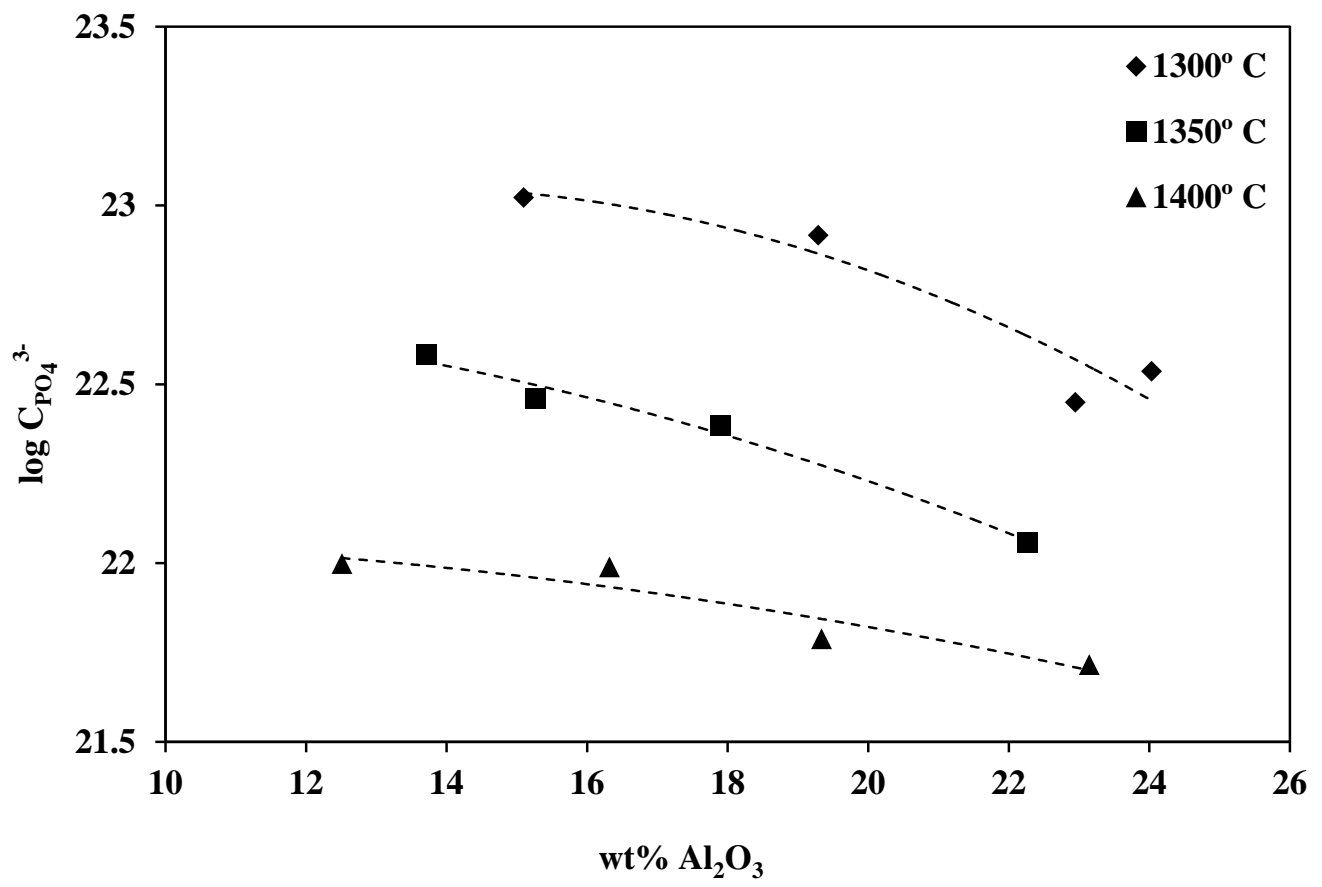

Figure 4-32: Relationship between the phosphate capacity and wt $\% \mathrm{Al}_{2} \mathrm{O}_{3}$ 


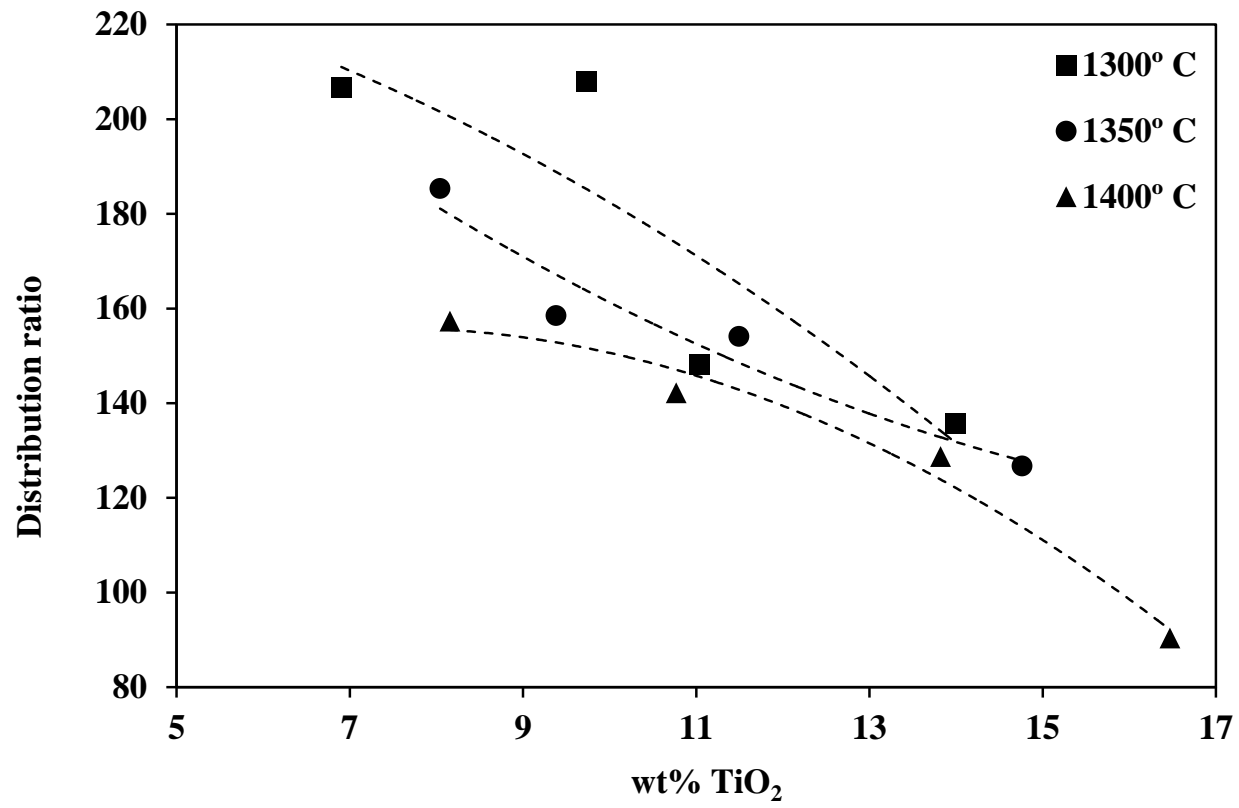

Figure 4-33: Relationship between the phosphorus distribution ratio $\left(\mathrm{L}_{\mathrm{P}}{ }^{\mathrm{Fe}-\mathrm{C}}\right)$ and wt $\% \mathrm{TiO}_{2}$

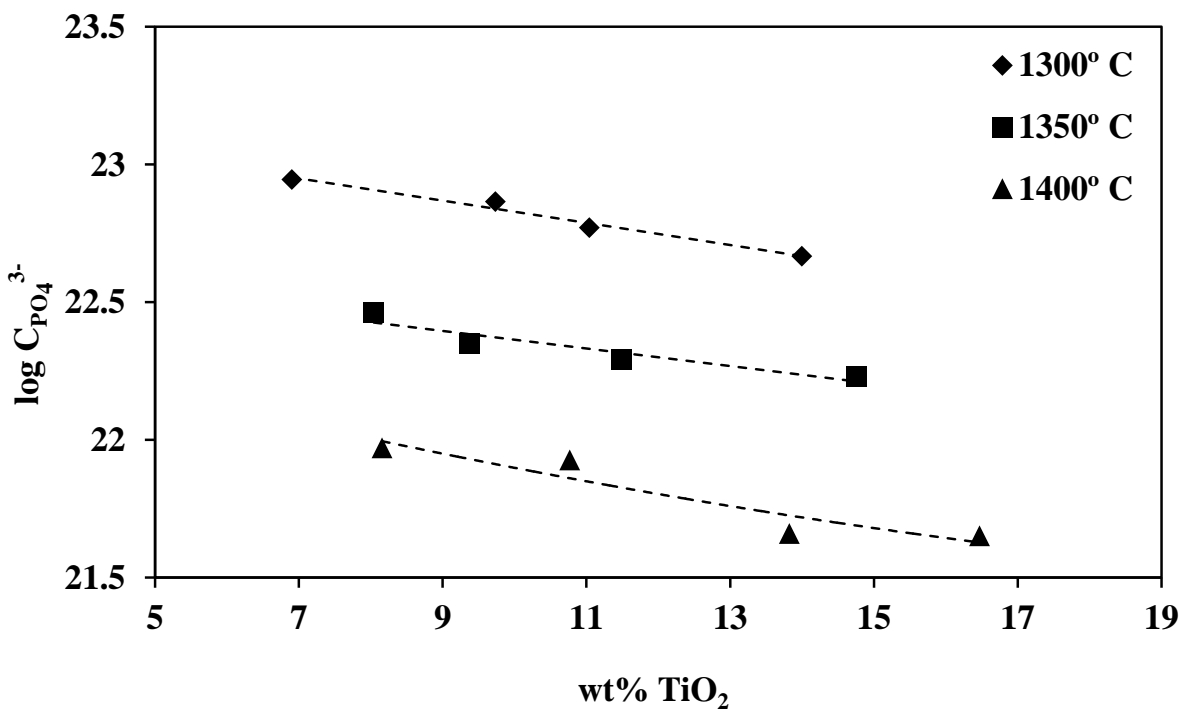

Figure 4-34: Relationship between the phosphate capacity and $\mathrm{wt} \% \mathrm{TiO}_{2}$

It is well known that during dephosphorization, phosphate ions $\mathrm{PO}_{4}{ }^{3-}$ replace $\mathrm{SiO}_{4}{ }^{4-}$ and participate in $2 \mathrm{CaO} . \mathrm{SiO}_{2}$ solid solution[87]. On the other hand, in the network structure of silicate slag some cations such as $\mathrm{Al}^{3+}$ and $\mathrm{Ti}^{4+}$ can form tetrahedral units that are incorporated into the silicate network like $\mathrm{AlO}_{4}{ }^{5-}$ and $\mathrm{TiO}^{4-}$ [34]. Thus increasing $\mathrm{Al}_{2} \mathrm{O}_{3}$ or $\mathrm{TiO}_{2}$ content prevents the ions $\mathrm{PO}_{4}{ }^{3-}$ to participate in $2 \mathrm{CaO} . \mathrm{SiO}_{2}$ and decreases the holding capacity of slag for 
phosphorus or in other words decreasing the phosphate capacity. Consequently, increasing $\mathrm{Al}_{2} \mathrm{O}_{3}$ and $\mathrm{TiO}_{2}$ content show a decreasing effect on dephosphorization. The same tendency was observed by Jiang [110] as depicted in Figure 4-35 and Figure 4-36.

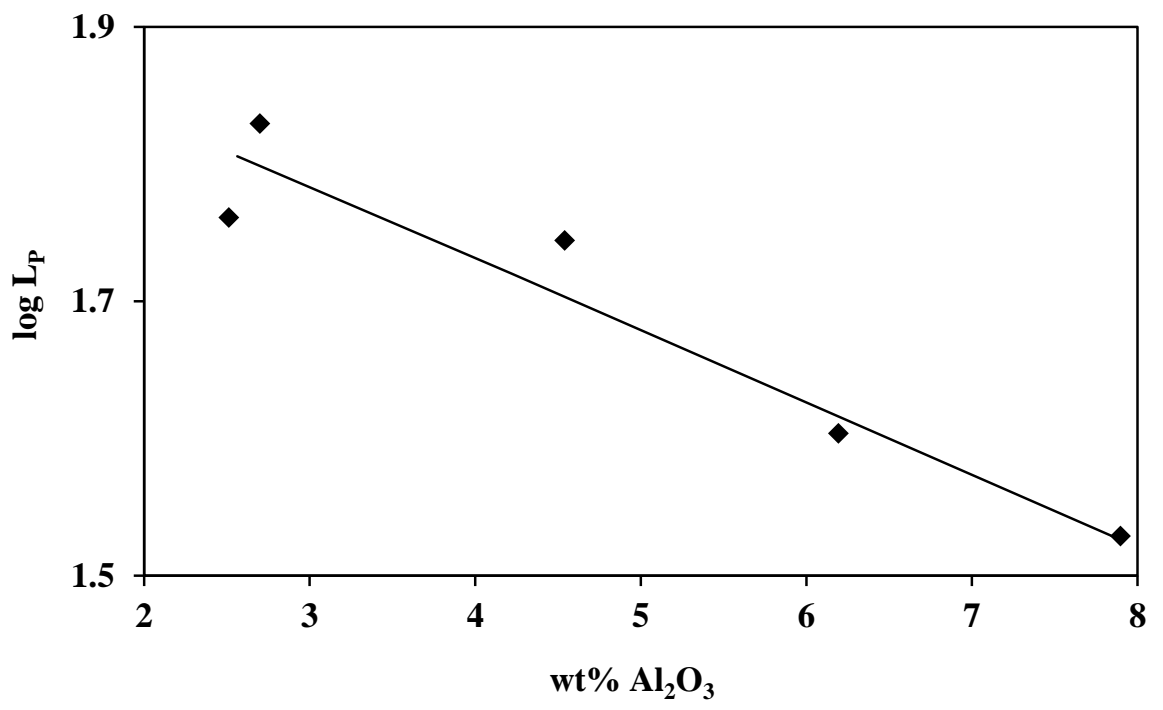

Figure 4-35: Effect of $\mathrm{Al}_{2} \mathrm{O}_{3}$ on the phosphorus distribution ratio at $1350{ }^{\circ} \mathrm{C}$ [110]

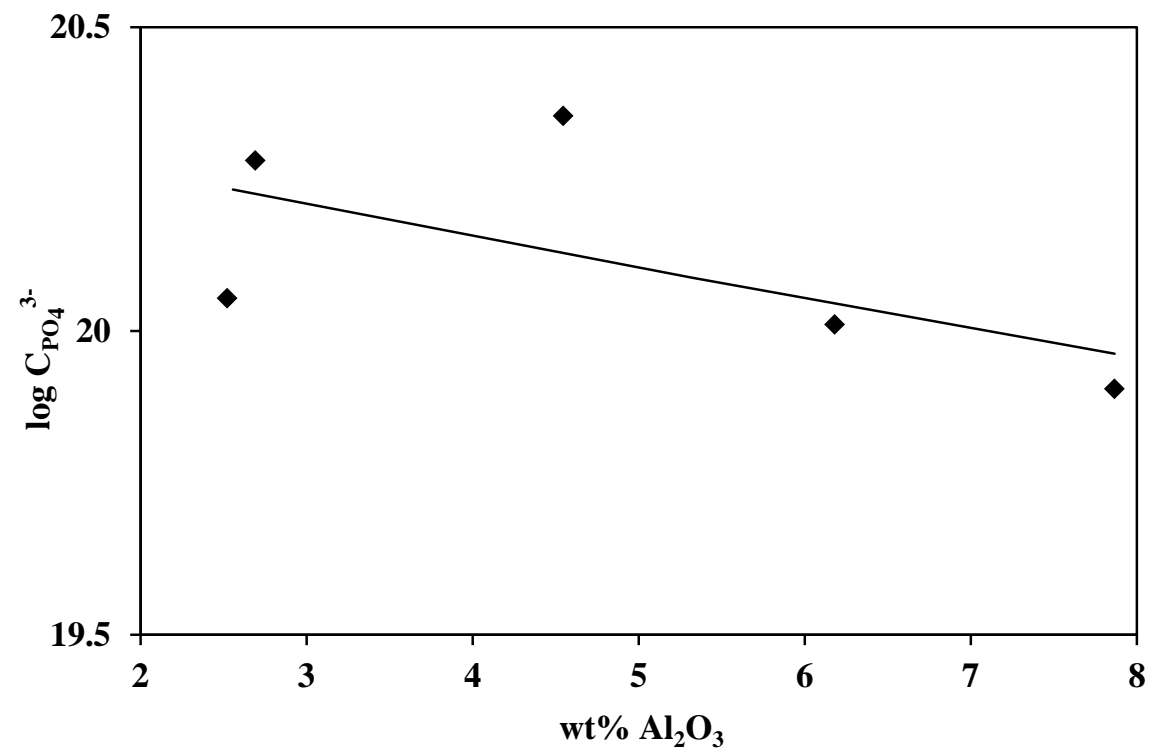

Figure 4-36: Effect of $\mathrm{Al}_{2} \mathrm{O}_{3}$ on the phosphate capacity at $1350{ }^{\circ} \mathrm{C}$ [110] 
The activity coefficient of $\mathrm{P}_{2} \mathrm{O}_{5}\left(\gamma_{P_{2} O_{5}}\right)$ in slag is an important thermodynamic parameter that affects its behavior in hot metal pre-treatment [81, 111, 112]. According to Jiang, [110] $\mathrm{Al}_{2} \mathrm{O}_{3}$ addition increases the activity coefficient of $\mathrm{P}_{2} \mathrm{O}_{5}$ (Figure 4-37), which increases the activity of $\mathrm{P}_{2} \mathrm{O}_{5}$ at constant mole fraction and consequently gives rise to lower phosphate capacity.

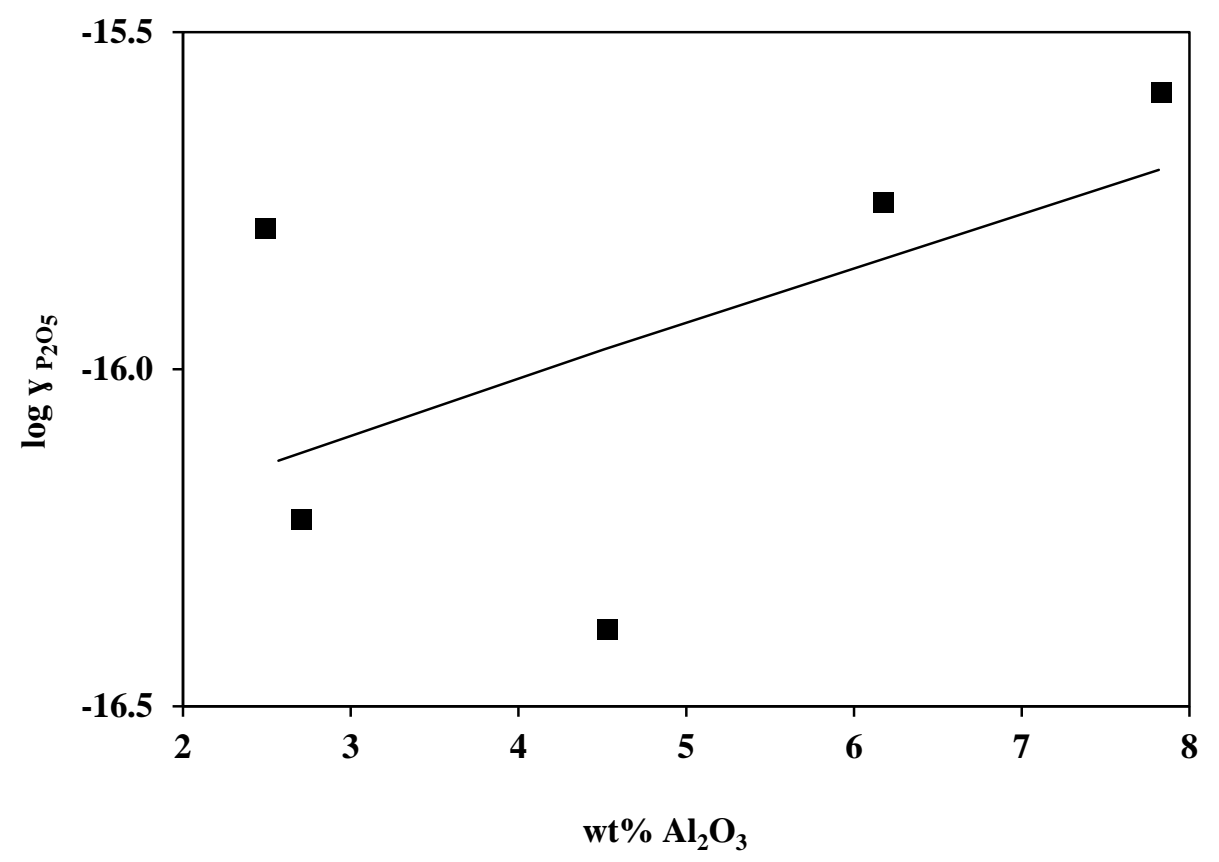

Figure 4-37: Effect of $\mathrm{Al}_{2} \mathrm{O}_{3}$ on the activity coefficient of $\mathrm{P}_{2} \mathrm{O}_{5}$ at $1350^{\circ} \mathrm{C}[110]$

\subsubsection{Effect of $\mathrm{SiO}_{2}$ on the phosphorus distribution ratio and phosphate capacity}

The effect of $\mathrm{SiO}_{2}$ on the phosphorus partition ratio and phosphate capacity of synthetic red mud based fluxes (SRM-15 through SRM-18) in the range of $1300-1400{ }^{\circ} \mathrm{C}$ are plotted in Figure 4-38 and Figure 4-39. It can be observed that $\mathrm{LP}_{\mathrm{P}}$ and $\mathrm{C}_{\mathrm{PO}_{4}^{3-}}$ decreases with increasing $\mathrm{SiO}_{2}$ content.

This tendency can be attributed to the variation of basicity with the addition of an acidic oxide such as $\mathrm{SiO}_{2}$. The activity coefficient of $\mathrm{P}_{2} \mathrm{O}_{5}$ is increased with the addition of acidic oxides, resulting in reduced phosphate capacity of slag $[81,111,112]$. 


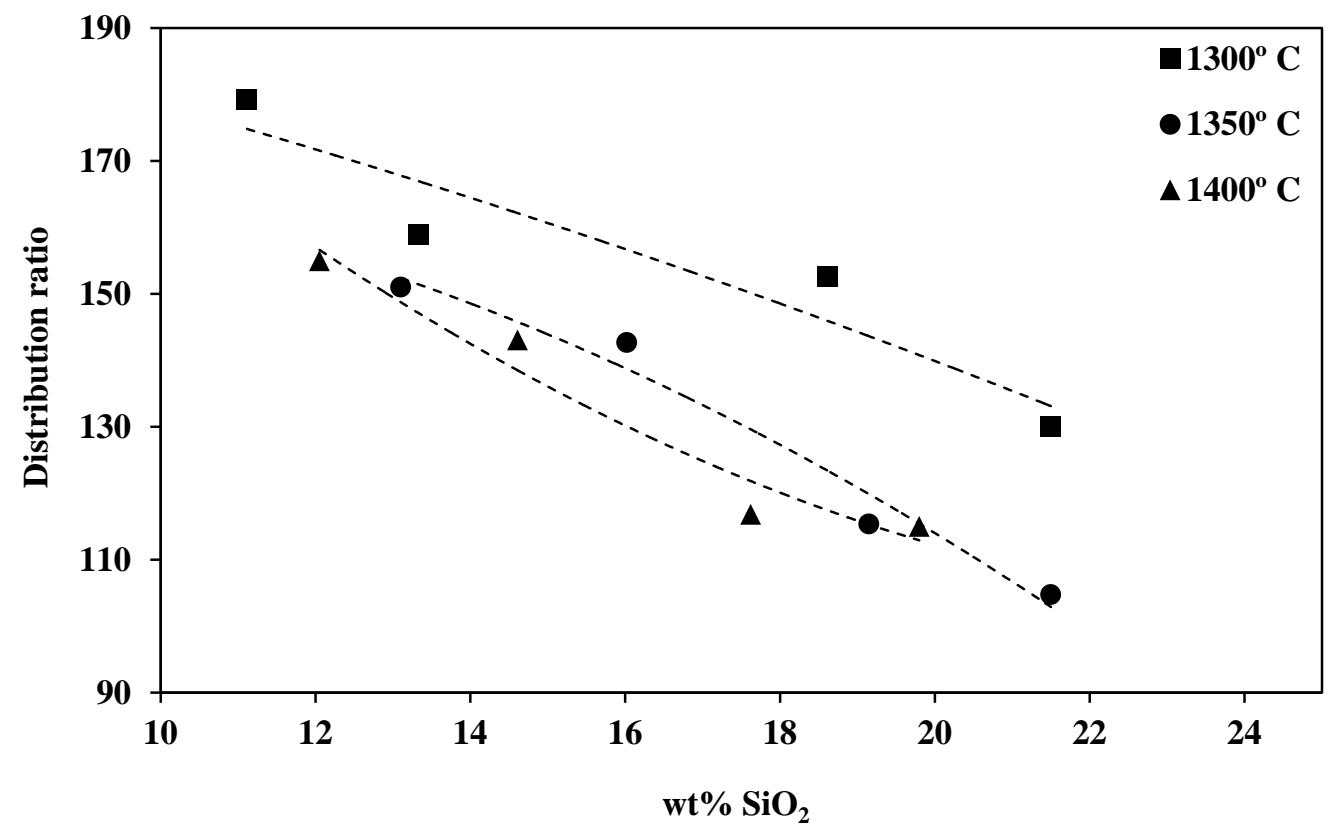

Figure 4-38: Relationship between the Phosphorus distribution ratio $\left(\mathrm{L}_{\mathrm{P}}{ }^{\mathrm{Fe}-\mathrm{C}}\right)$ and $\mathrm{wt} \% \mathrm{SiO}_{2}$

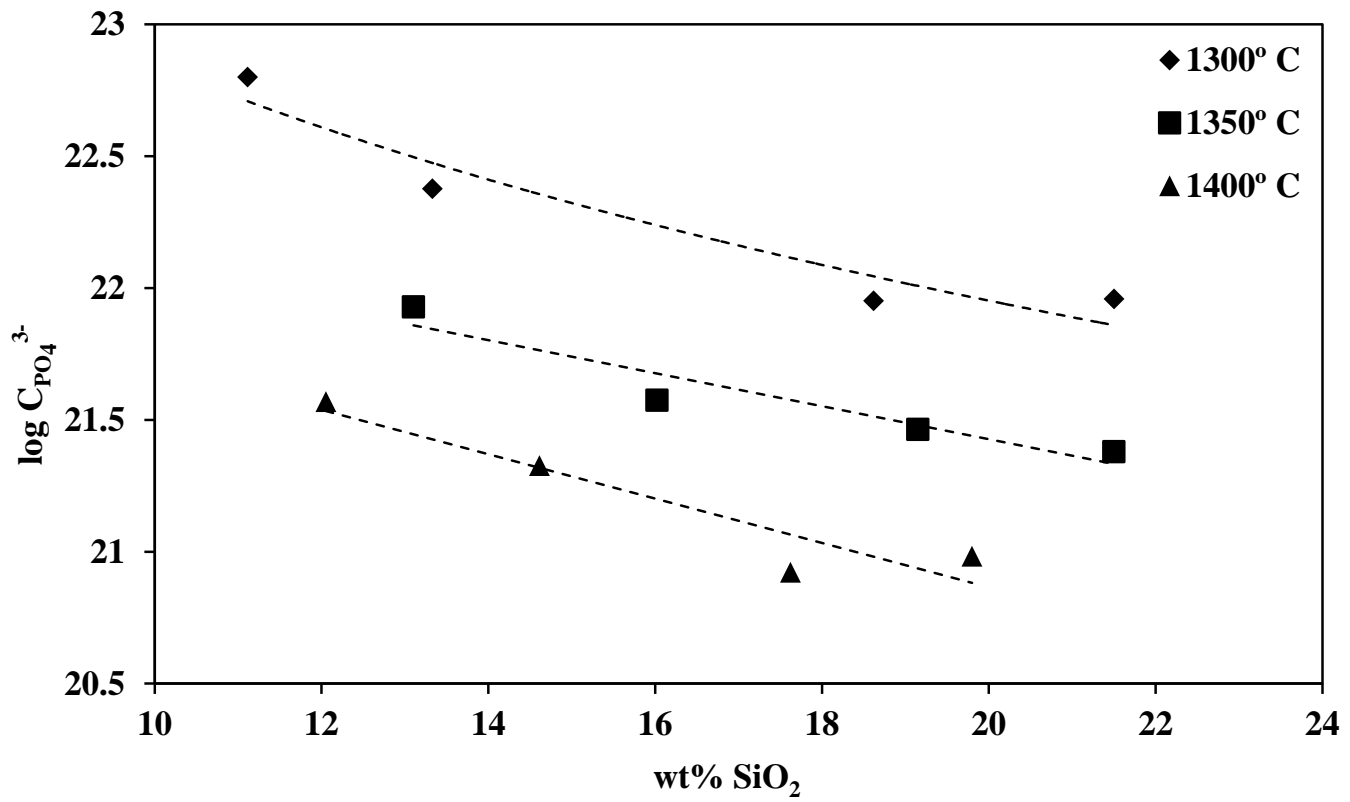

Figure 4-39: Relationship between the Phosphate capacity and wt $\% \mathrm{SiO}_{2}$ 


\subsection{Melting behaviour}

The melting behaviour of the red mud samples RMF1-RMF18 (Table 3-2) was determined using a high temperature microscopy method, and the average values of the characteristic temperatures, standard deviations and standard errors based on three repeats for each composition are presented in Table 4-12. The typical recorded image of the sample RMF4 corresponding to the characteristic temperatures are illustrated in Figure 4-40.

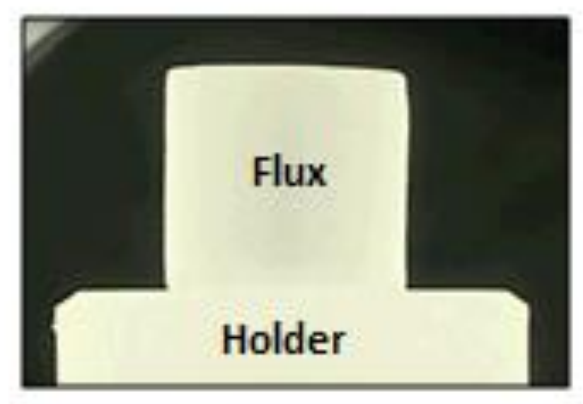

(a) Initial shape

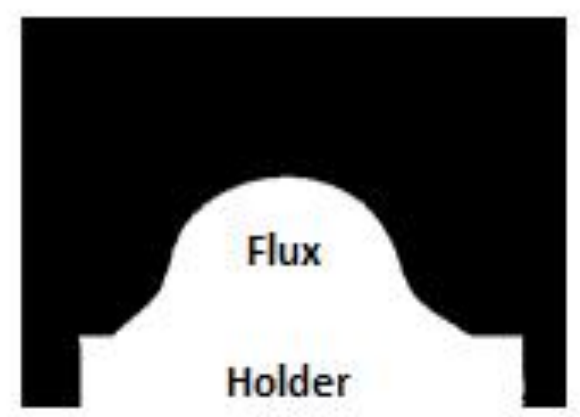

(c) Hemispherical temperature

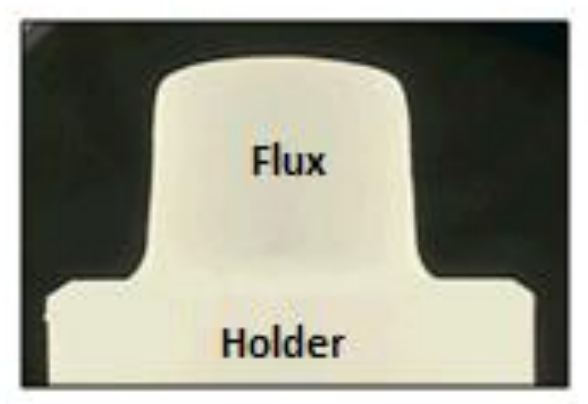

(b) Deformation temperature

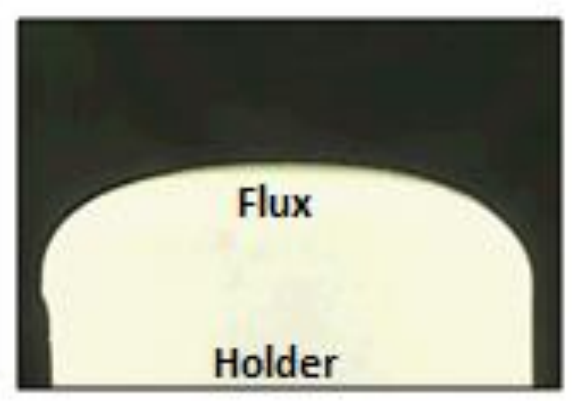

(d) Flowing temperature

Figure 4-40: Typical captured image of characteristic temperatures belong to sample RMF4

Upon heating the compacts, a slight expansion was observed in some samples. This can be due to the release of water vapor and other gases formed during the decomposition of goethite, gibbsite, and calcite. This early swelling was followed by shrinkage and corresponds to the deformation temperature and initial melting of the flux. Subsequently, the sample melted partially with the 
formation of a cap on top of the compact (hemispherical temperature). Finally, on full melting, the flux became fluid and spread over the sample holder (flowing temperature).

Table 4-12: The average characteristic temperatures, standard deviations and standard errors for red mud based fluxes

\begin{tabular}{|c|c|c|c|c|c|c|c|c|c|}
\hline \multirow{2}{*}{ Sample } & \multicolumn{3}{|c|}{$\begin{array}{l}\text { Deformation Temperature } \\
\text { (DT) }\end{array}$} & \multicolumn{3}{|c|}{$\begin{array}{l}\text { Hemispherical Temperature } \\
\text { (HT) }\end{array}$} & \multicolumn{3}{|c|}{$\begin{array}{l}\text { Flowing Temperature } \\
\text { (FT) }\end{array}$} \\
\hline & ${ }^{\circ} \mathrm{C}$ & $\mathrm{SD}^{*}$ & $\mathrm{SE}^{* *}$ & ${ }^{\circ} \mathrm{C}$ & $\mathrm{SD}^{*}$ & $\mathrm{SE}^{* *}$ & ${ }^{\circ} \mathrm{C}$ & $\mathrm{SD}^{*}$ & $\mathrm{SE}^{* *}$ \\
\hline RMF1 & 1264 & 10 & 6 & 1274 & 6 & 3 & 1280 & 9 & 5 \\
\hline RMF2 & 1227 & 6 & 3 & 1234 & 9 & 5 & 1257 & 7 & 4 \\
\hline RMF3 & 1163 & 11 & 7 & 1172 & 13 & 7 & 1176 & 12 & 7 \\
\hline RMF4 & 1154 & 9 & 5 & 1163 & 9 & 5 & 1170 & 8 & 5 \\
\hline RMF5 & 1214 & 9 & 5 & 1224 & 10 & 6 & 1232 & 8 & 5 \\
\hline RMF6 & 1235 & 11 & 6 & 1259 & 10 & 6 & 1288 & 8 & 4 \\
\hline RMF7 & 1147 & 8 & 5 & 1174 & 11 & 6 & 1193 & 11 & 6 \\
\hline RMF8 & 1156 & 10 & 6 & 1184 & 14 & 8 & 1207 & 13 & 8 \\
\hline RMF9 & 1172 & 9 & 5 & 1193 & 11 & 6 & 1222 & 11 & 6 \\
\hline RMF10 & 1184 & 9 & 5 & 1223 & 10 & 6 & 1237 & 11 & 6 \\
\hline RMF11 & 1164 & 13 & 8 & 1212 & 13 & 7 & 1250 & 11 & 6 \\
\hline RMF12 & 1224 & 10 & 6 & 1276 & 9 & 5 & 1293 & 7 & 4 \\
\hline RMF13 & 1263 & 9 & 5 & 1308 & 8 & 5 & 1350 & 8 & 5 \\
\hline RMF14 & 1288 & 9 & 5 & 1349 & 15 & 8 & 1411 & 12 & 7 \\
\hline RMF15 & 1218 & 12 & 7 & 1235 & 9 & 5 & 1250 & 7 & 4 \\
\hline RMF16 & 1214 & 9 & 5 & 1223 & 8 & 5 & 1233 & 7 & 4 \\
\hline RMF17 & 1205 & 9 & 5 & 1212 & 9 & 5 & 1225 & 10 & 6 \\
\hline RMF18 & 1200 & 12 & 7 & 1211 & 9 & 5 & 1221 & & 5 \\
\hline
\end{tabular}

SD*: Standard deviation

SE**: Standard error 


\subsubsection{The relationship between flux components and melting behavior}

\subsubsection{Effect of $\mathrm{CaO}$ on the melting behavior}

The effect of lime content on the characteristic temperatures of fluxes RMF1 through RMF6 is shown in Figure 4-41 with increasing lime content all three temperatures decrease to a minimum, corresponding to a mass content of $33 \mathrm{wt} \% \mathrm{CaO}$. The phase diagram of $\mathrm{CaO}-\mathrm{SiO}_{2}$ system is shown in Figure 4-42.

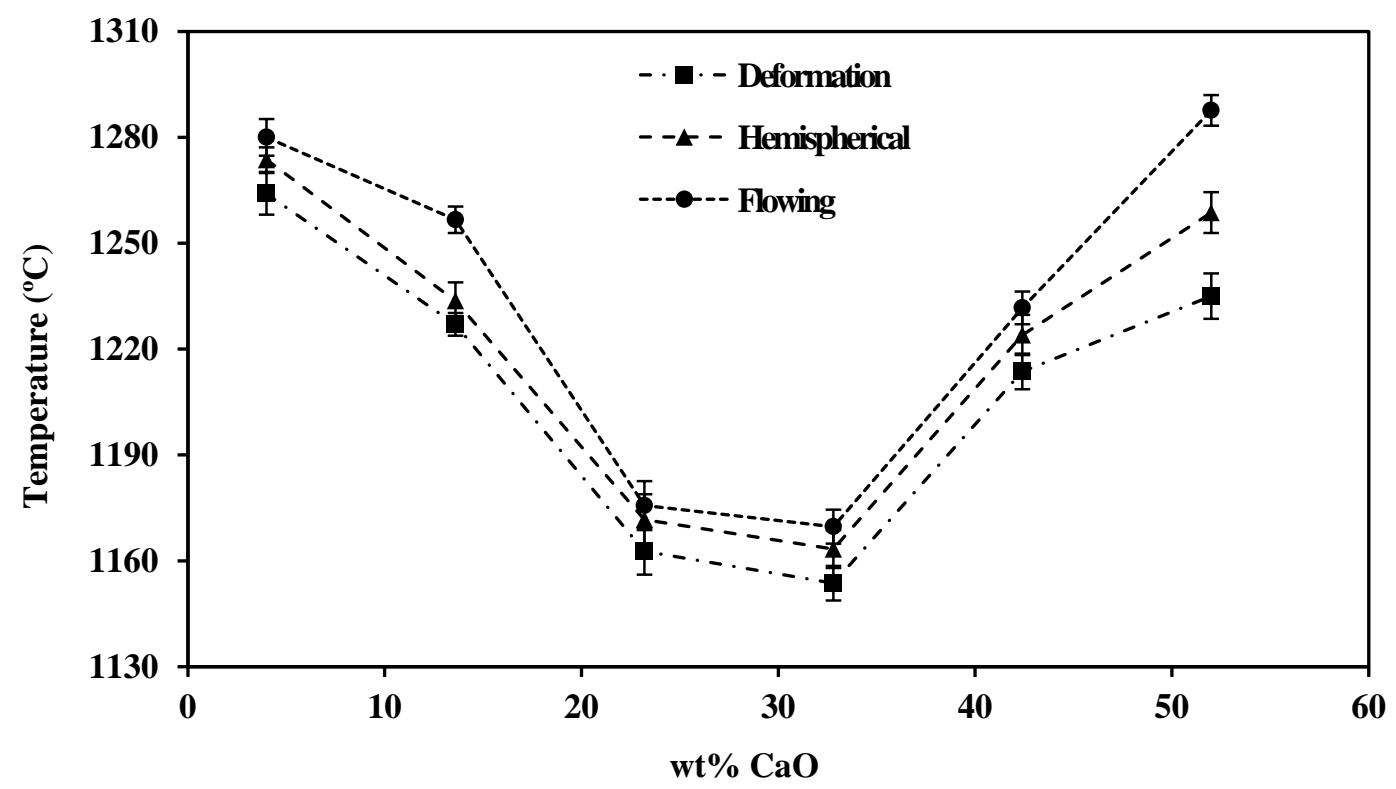

Figure 4-41: Effect of lime on characteristic temperatures of fluxes RMF1 through RMF6

As seen, addition of lime, a basic component, to an acidic flux such as silica leads to the formation of phases with melting point lower than the melting point of individual components. Addition of excess lime, over 33\% in this case, results in over-saturating the liquid and formation of undissolved lime that raises the characteristic temperatures. Although the flux system here is more complex than the binary $\mathrm{CaO}-\mathrm{SiO}_{2}$ system, the same trends can take place, as commonly seen in ternary or higher order systems.

A secondary reason for the variations of the characteristic temperatures, the FT in particular, is the change in slag structure with composition. From a fundamental point of view, the building unit in molten silicates is the tetrahedron $\mathrm{SiO}_{4}{ }^{4-}$. $\mathrm{The}_{\mathrm{SiO}}{ }_{4}{ }^{4-}$ tetrahedra are joined together in three 
dimensional silicate networks. The addition of a basic oxide such as lime breaks down the silicate structure and depolymerizes the network, lowering the characteristic temperatures.

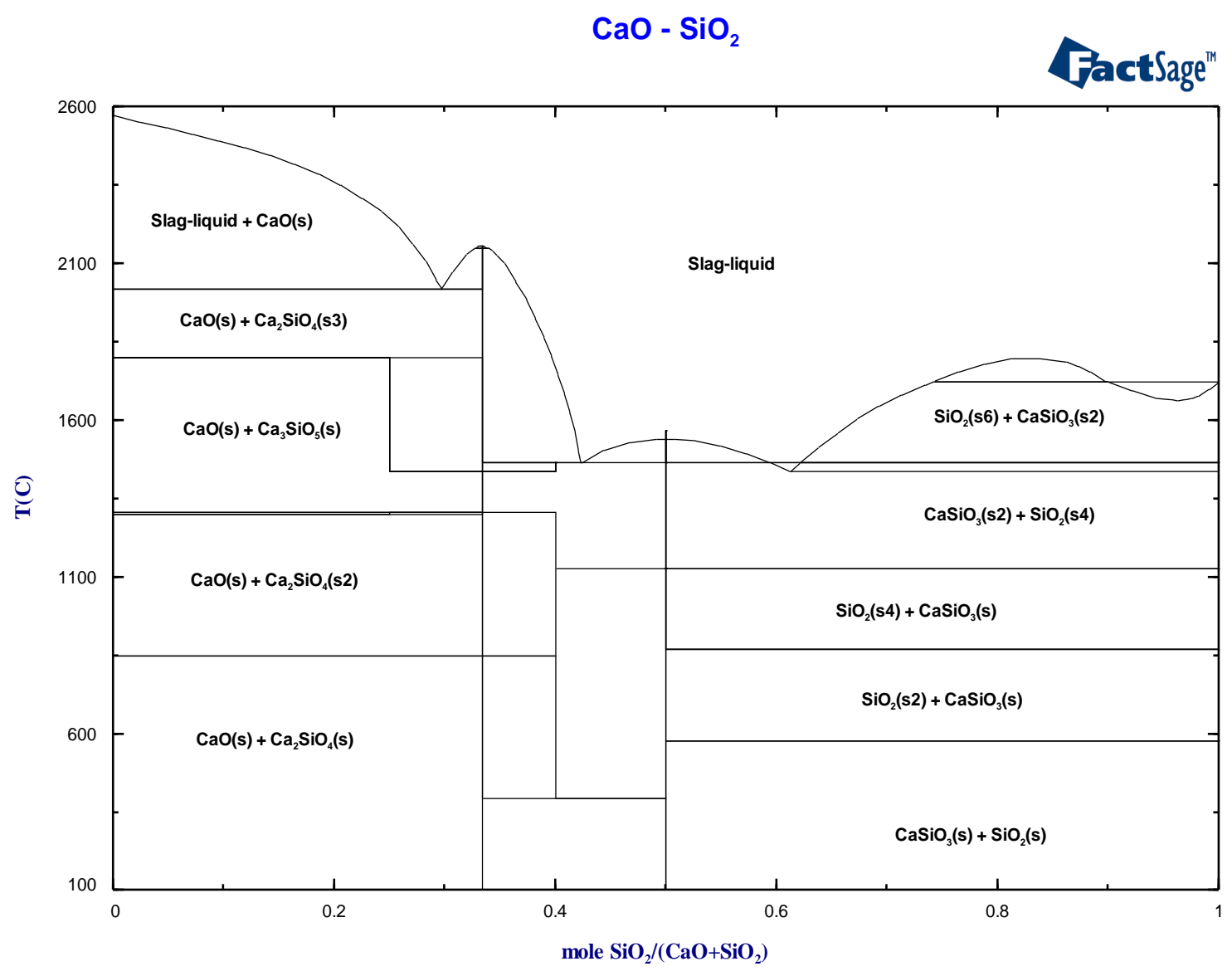

Figure 4-42: Phase diagram of $\mathrm{CaO}-\mathrm{SiO}_{2}$ system [113]

\subsubsection{Effect of $\mathrm{Al}_{2} \mathrm{O}_{3}, \mathrm{TiO}_{2}$ and $\mathrm{SiO}_{2}$ on the melting behavior}

In order to investigate the effect of chemical composition on the characteristic temperatures, different amounts of $\mathrm{Al}_{2} \mathrm{O}_{3}, \mathrm{TiO}_{2}$ and $\mathrm{SiO}_{2}$ were added to the flux RMF4 (Table 3-2) which was found to exhibit the lowest characteristic temperatures. The results in Figure 4-43 (RMF7 through RMF10) and Figure 4-44 (RMF11 through RMF14) indicate that the characteristic temperatures of the fluxes all increase with the addition of alumina and titania, an indication that they act as network formers for the composition range covered. 


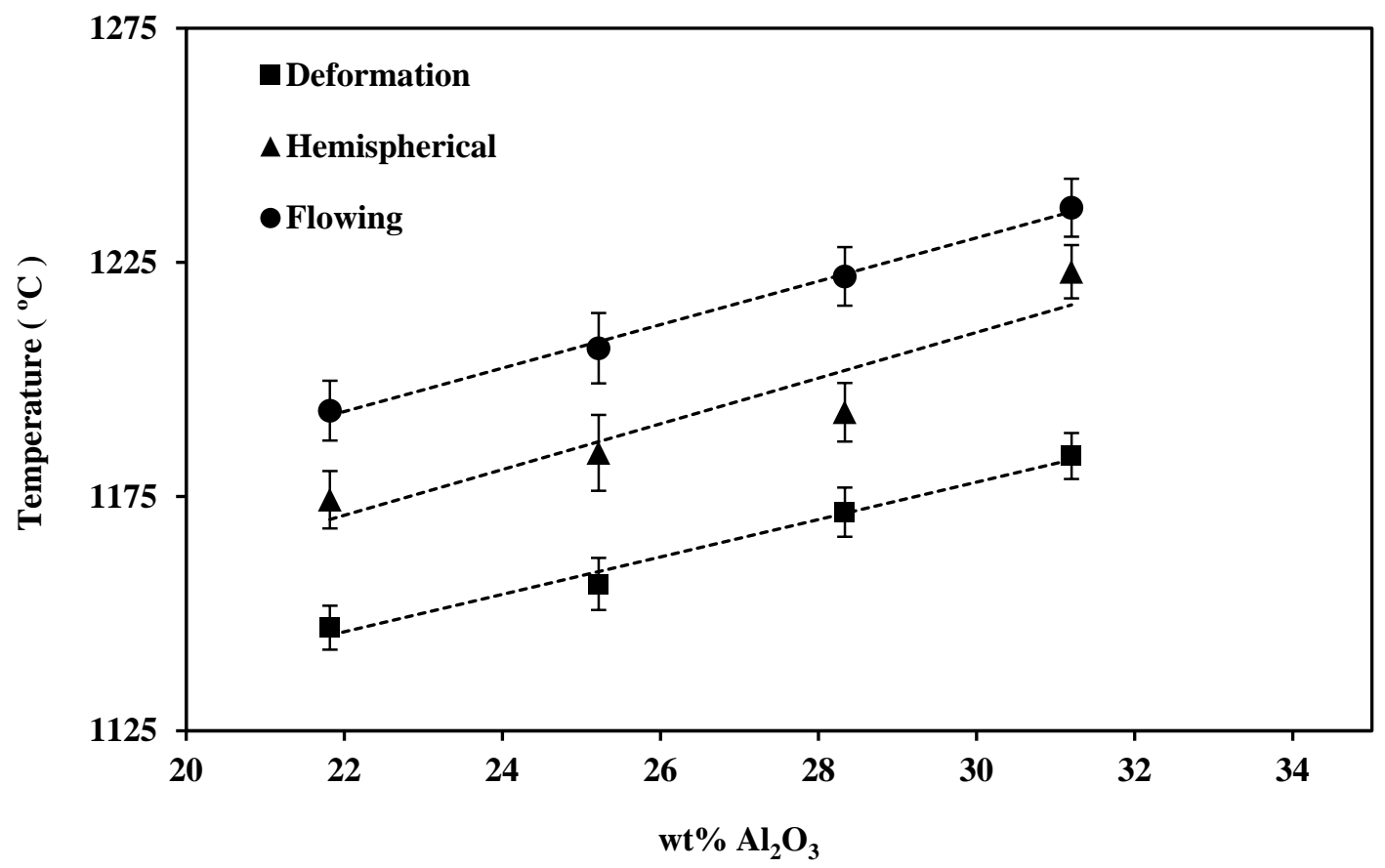

Figure 4-43: Effect of alumina on characteristic temperatures of fluxes RMF7 through RMF10

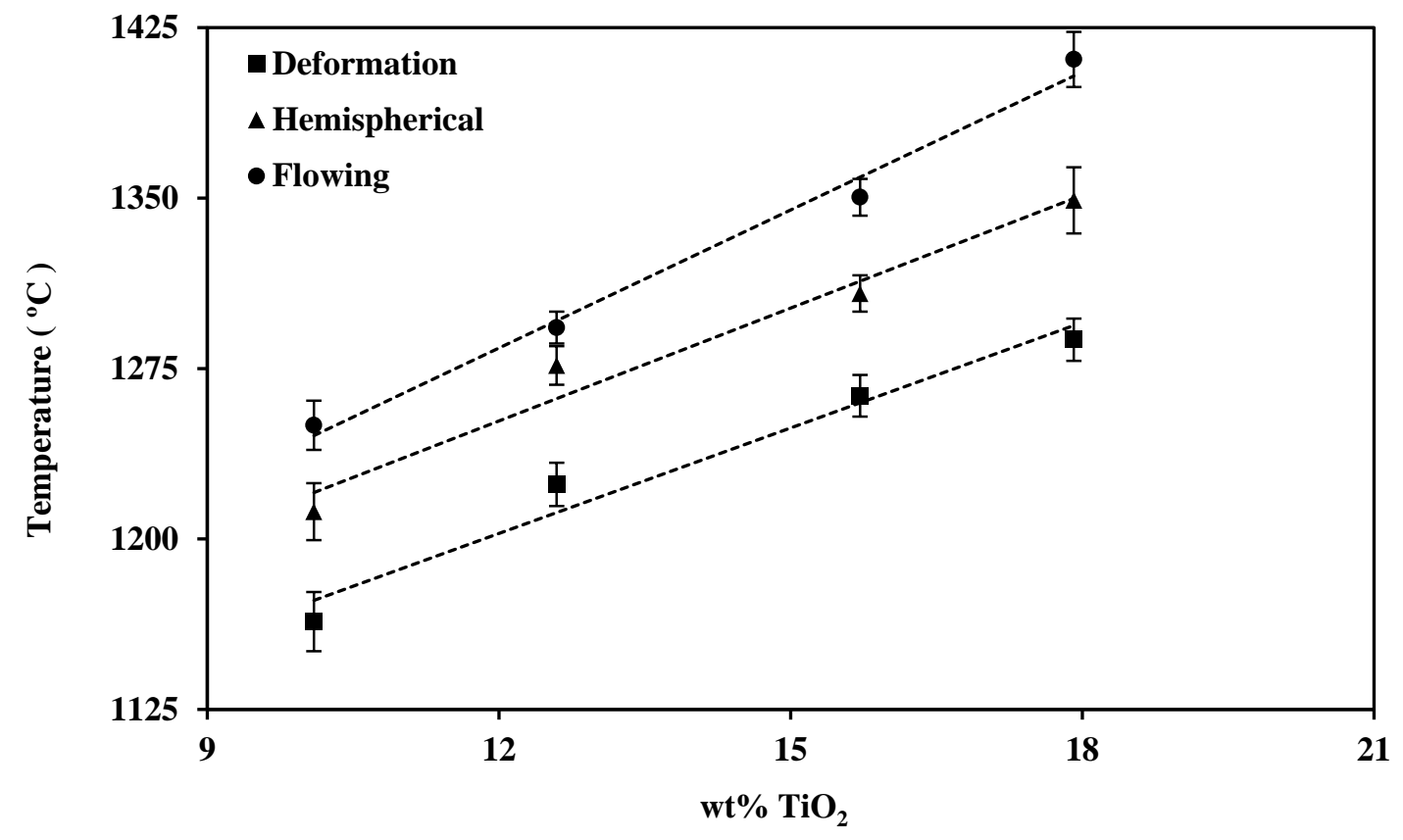

Figure 4-44: Effect of titanium oxide on characteristic temperatures of fluxes RMF11 through RMF14 
The relationship between characteristic temperatures of fluxes RMF15 through RMF18 and silica content is presented in Figure 4-45. As seen, the characteristic temperatures gradually decrease with increasing the silica content. Again, the trend can be explained by the phase diagram of $\mathrm{CaO}-\mathrm{SiO}_{2}$, in which addition of silica to a highly basic system should decrease the melting point.

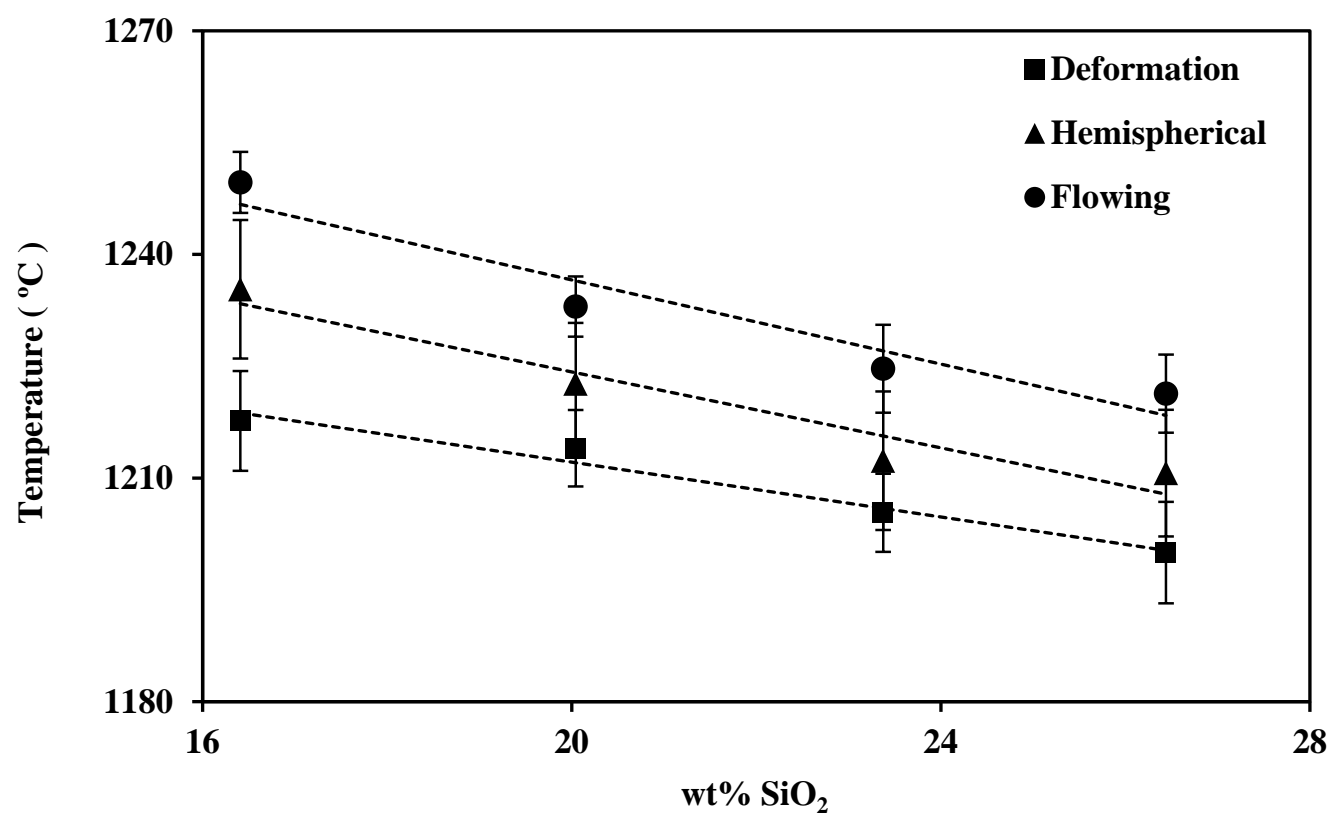

Figure 4-45: Effect of silica on characteristic temperatures of fluxes RMF15 through RMF18

FactSage $^{\text {TM }}$ thermodynamic package was used to determine the amount of liquid phase at high temperatures for different compositions (RMF7 through RMF18). The mass percentage of liquid phase as a function alumina, titanium oxide and silicon oxide at different temperatures is plotted in Figure 4-46, Figure 4-47 and Figure 4-48 respectively. It can be seen that the experimental findings are in agreement with the results of the calculations.

In Figure 4-46 and Figure 4-47 with increasing alumina and titanium oxide, the amount of high melting point phases such as Gehlenite $\left(\mathrm{Ca}_{2} \mathrm{Al}_{2} \mathrm{SiO}_{7}\right)$ and perovskite $\left(\mathrm{CaTiO}_{3}\right)$ increases respectively. As a result, the portion of liquid slag at a constant temperature decreases, raising the characteristic temperatures that were observed in Figure 4-43 and Figure 4-44. 


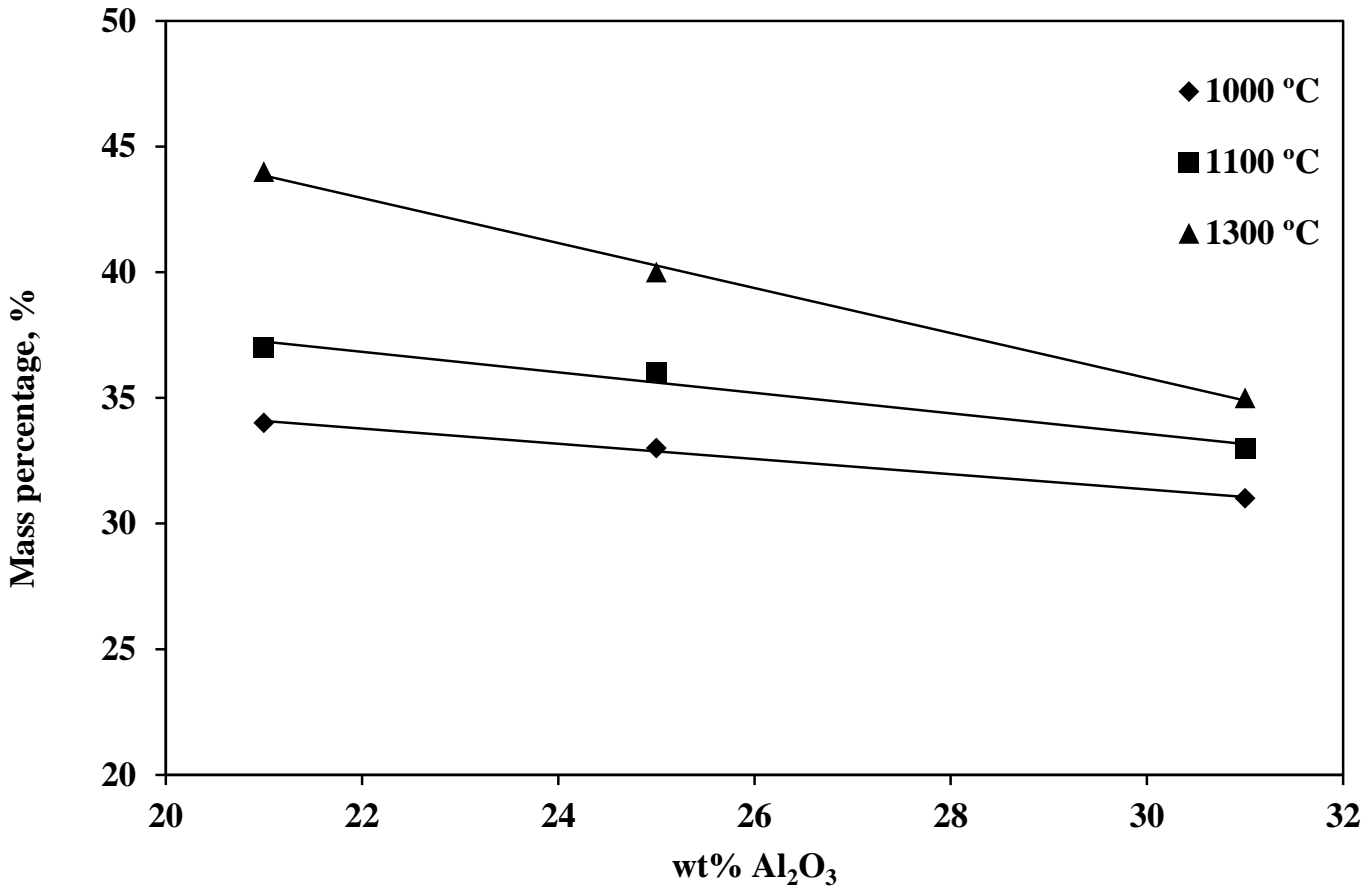

Figure 4-46: Mass percentage of liquid phase in slag vs. alumina content at different temperatures

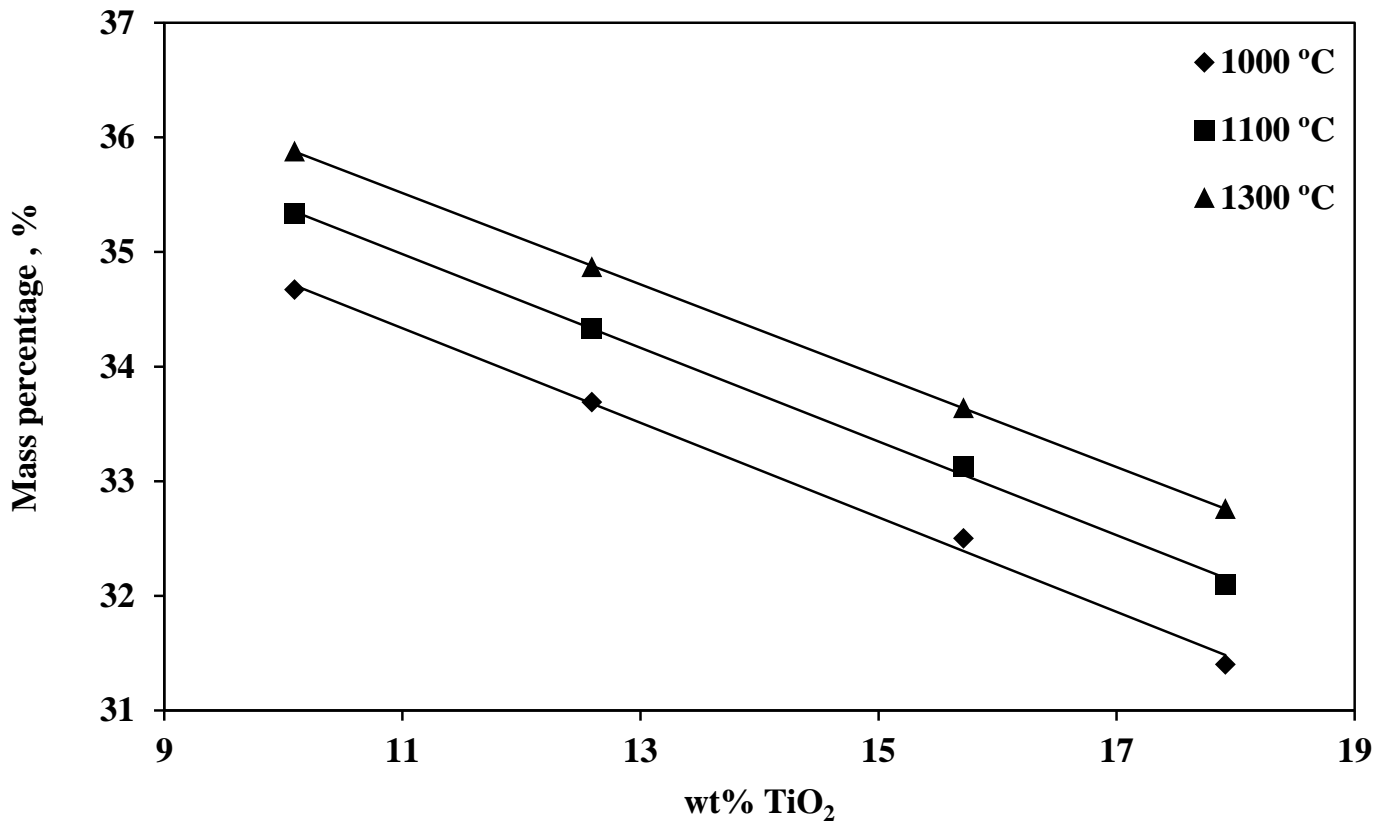

Figure 4-47: Mass percentage of liquid phase in slag vs. titania content at different temperatures 
In Figure 4-48 with increasing $\mathrm{SiO}_{2}$ the percentage of the liquid phase increases. This can be related to forming low melting point phases and decreasing the high melting point phase such as Gehlenite $\left(\mathrm{Ca}_{2} \mathrm{Al}_{2} \mathrm{SiO}_{7}\right)$.

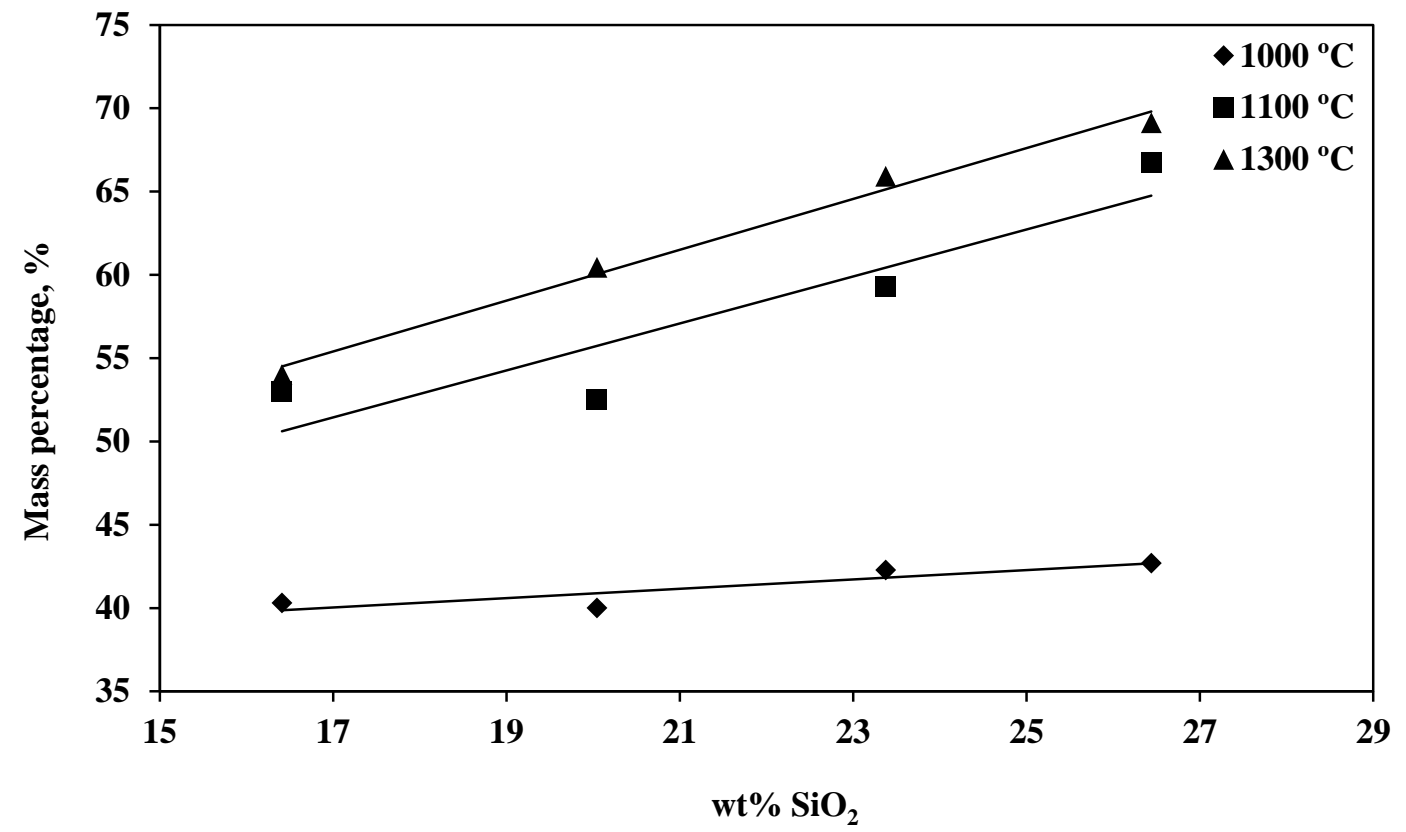

Figure 4-48: Mass percentage of liquid phase in slag vs. silica content at different temperatures

\subsubsection{Effect of Basicity}

Traditionally, the ratio of basic oxides to acidic oxides is used as a measure of slag basicity. The effect of basicity on the characteristic temperatures of mold fluxes for continuous casting is illustrated in Figure 4-49 [114]. Basicity ratios between 1.0 and 1.1 correspond to the lowest characteristic temperatures. Increasing the $\mathrm{CaO}$ or $\mathrm{SiO}_{2}$ contents beyond this optimum ratio results in higher temperatures. Thus, to have a flux with relatively low characteristic temperatures, basic and acidic components should be mixed in appropriate amounts.

For multi-component fluxes with constituents that possess different basic strengths, the simple $\left(\mathrm{CaO} / \mathrm{SiO}_{2}\right)$ ratio does not provide a true measure of the flux basicity. In this work, the optical basicity is used as a more appropriate indicator to correlate different flux compositions with the corresponding melting characteristics. 


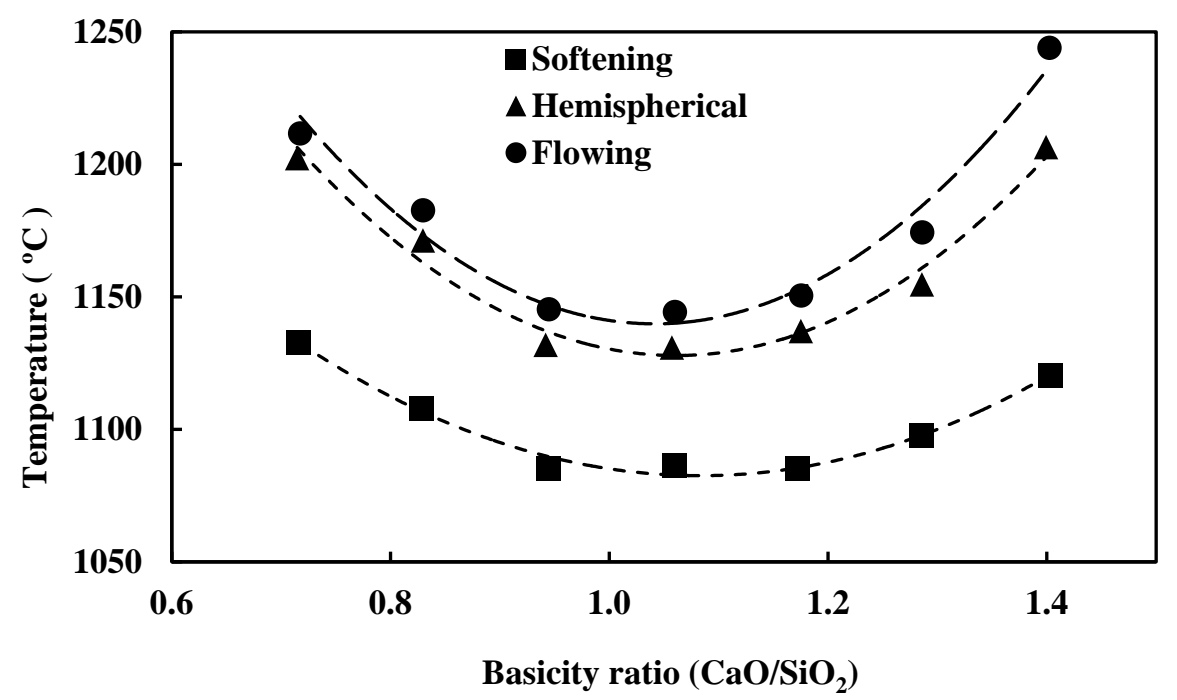

Figure 4-49: Characteristic temperatures of mold fluxes as a function of the $\mathrm{CaO} / \mathrm{SiO}_{2}$ ratio[114]

Table 3-2 presents the values of optical basicity for the flux compositions studied here. The variation in the characteristic temperatures of fluxes RMF1 through RMF6 as a function of the optical basicity is shown in Figure 4-50. It can be seen that with an increase in optical basicity, the characteristic temperatures approach a minimum, indicating optimum flux composition for better fluidity. The minimum appears to occur at optical basicity of $\sim 0.77$, corresponding to a mass content of $33 \mathrm{wt} \% \mathrm{CaO}$. This is expected as discussed earlier based on the effect of lime content on the melting properties.

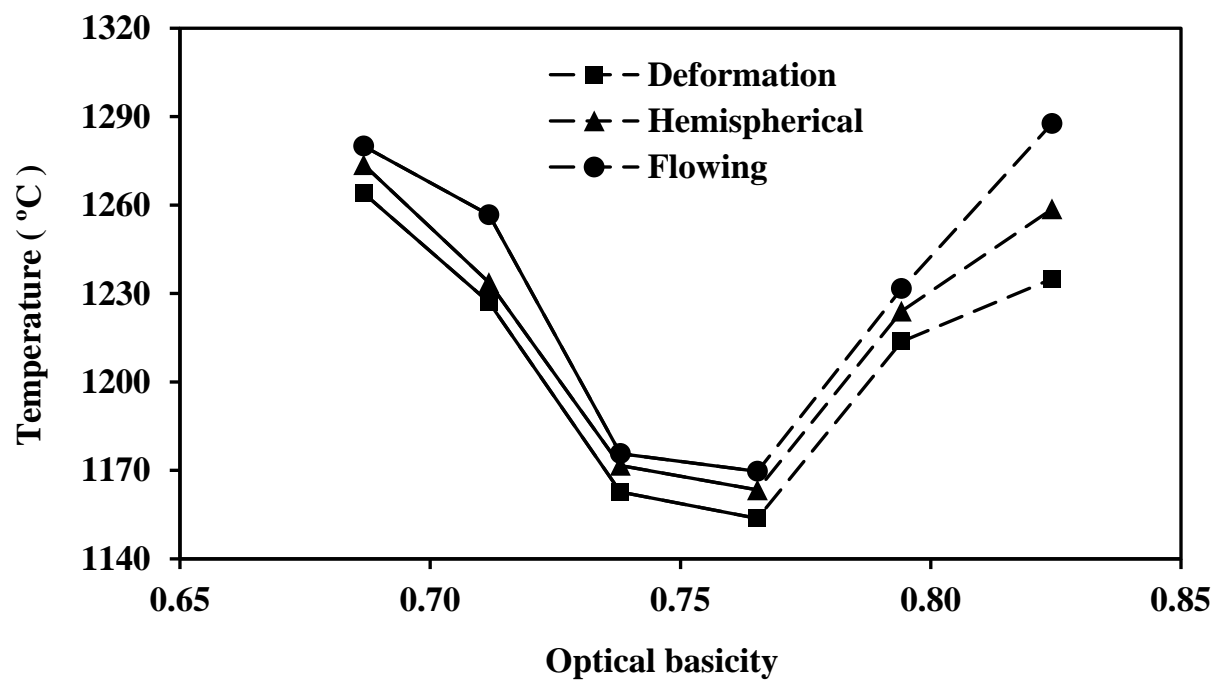

Figure 4-50: Characteristic temperatures as a function of the optical basicity for RMF1 through RMF6 fluxes 


\section{Chapter 5}

\section{Conclusions and Impact of Research}

\subsection{Conclusions}

The overall objective of this work was to evaluate the potential use of red mud, a waste material, as a refining flux with high capacity for removal of sulphur and phosphorus from hot metal in the steel manufacturing process. This section summarizes the major findings.

\section{1- Characterization of red mud}

The results from XRD and XRF analyses of red mud show that it contains a number of different constituents in the form of oxides or hydroxides of iron, aluminum, silicon, sodium, and titanium.

The thermal events observed by TGA-DSC curves up to $1400{ }^{\circ} \mathrm{C}$ were explained in detail. Mass loss up to $\sim 720{ }^{\circ} \mathrm{C}$ indicated decomposition of various hydrated phases including gibbsite, goethite and calcite. This was consistent with DSC results, showing the endothermic nature of these reactions.

\section{2- Sulphide capacity of red mud based fluxes}

Desulphurization experiments were carried out using a slag - metal equilibrium technique in graphite crucibles under carbon monoxide atmosphere in the temperature range 1300 to $1400^{\circ} \mathrm{C}$ to investigate the capability of the red mud based fluxes as a desulphurization refining agent in hot metal pretreatment. The results indicate that the sulphide capacity is influenced by the chemical composition and temperature. The sulphide capacity is found to increase with lime content for all temperatures, and reaches a maximum at $\sim 46-49 \% \mathrm{CaO}$. Further increase in lime did not improve the sulphide capacity. Addition of $\mathrm{Al}_{2} \mathrm{O}_{3}, \mathrm{TiO}_{2}$ and $\mathrm{SiO}_{2}$ showed a continuous decrease in the sulphide capacity. The effect of various oxides on the sulphide capacity was attributed to the nature (acid vs base) of the oxide so that basic oxides favour $\mathrm{S}$ removal. Oversaturating the slag with $\mathrm{CaO}$ however offers no benefit as it precipitates as solid phases that have little to no effect on $\mathrm{S}$ absorption. 
It was shown that the sulphide capacity increases with increasing temperature from $1300{ }^{\circ} \mathrm{C}$ to $1400{ }^{\circ} \mathrm{C}$ at fixed slag basicity (i.e. optical basicity). An optimum flux composition could be determined for maximum sulphide capacity with the aid of the optical basicity concept.

\section{3- Phosphate capacity of red mud based fluxes}

The phosphorus distribution ratios and phosphate capacity were measured by equilibrating the synthetic red mud fluxes with solid iron foil under an argon atmosphere at temperatures ranging from 1300 to $1400^{\circ} \mathrm{C}$. The results led to the following conclusions.

The equilibrium phosphorus distribution ratio initially increases with increasing $\mathrm{FeO}$ or $\mathrm{CaO}$ concentration in fluxes then change to a negative trend at higher concentrations of $\mathrm{FeO}$ or $\mathrm{CaO}$.

The maximum phosphorus distribution ratios were obtained at $26 \% \mathrm{FeO}(39 \% \mathrm{CaO}), 28$ wt $\%$ $\mathrm{FeO}(32 \mathrm{wt} \% \mathrm{CaO})$ and $25 \% \mathrm{FeO}(41 \mathrm{wt} \% \mathrm{CaO})$ at $1300{ }^{\circ} \mathrm{C}, 1350{ }^{\circ} \mathrm{C}$ and $1400{ }^{\circ} \mathrm{C}$ respectively.

The phosphate capacity was found to decrease with increasing $\mathrm{Al}_{2} \mathrm{O}_{3}$, and $\mathrm{TiO}_{2}$, and $\mathrm{SiO}_{2}$.

\section{4- Melting behaviour study}

A high temperature microscopy technique was applied to investigate the melting behavior of red mud based fluxes. The results indicate that additions of lime from $10 \%$ to $32 \%$, lowered the characteristic melting/softening temperatures of red mud based fluxes while additions of $\mathrm{Al}_{2} \mathrm{O}_{3}$ and $\mathrm{TiO}_{2}$ had an opposite effect. Addition of lime over $32 \%$, corresponding to the saturation limit, increased the melting temperature of the flux. It was found that the flux has the lowest softening and flowing temperatures when the optical basicity is around 0.73 . This provides a foundation for engineering a flux which exhibits optimum melting characteristics as well as appropriate refining capabilities for the removal of impurities such as sulphur and phosphorus during metal processing operations. 


\subsection{Major contributions and potential impact}

The scientific significance of the present research lies in the generation of fundamental knowledge of the physical and chemical properties of red mud. The obtained results on refining characteristics of slags/fluxes provide a basis for not only utilization of red mud as the base material for a flux, but also improving current hot metal treatment practices.

This research can enable development of laboratory models that can be scaled up for red mud applications.

From a practical point of view, as the utilization of red mud based fluxes is implemented, significant benefits can be realized; reduced environmental footprint of aluminum production, effective utilization of a waste thereby reducing demand on the earth's resources, and economic benefits for the aluminum and steel industries. 


\section{Chapter 6}

\section{$6 \quad$ Future work}

The results of this study indicated that a suitable hot metal refining flux can be prepared based on the use of red mud. However, the following aspects are also of importance from both fundamental and practical viewpoints and need to be studied.

1- Kinetic study of S and P pick-up by slag

The present study was conducted from a thermodynamic perspective. It would be worthwhile to study the kinetics of desulphurization and dephosphorization of hot metal using the red mud based flux. The results would be particularly interesting as they would show the variation of the flux performance with time, as the composition changes due to decomposition of sodium oxide.

2- Effect of sodium oxide on refractory and off-gas

Since red mud contains a considerable amount of sodium oxide, the impact on the degradation of refractory materials should be investigated. Further, the rate of sodium oxide loss from slag, and possible complications in the off-gas handling system, such as condensation on the duct walls need to be evaluated.

3- Viscosity of red mud fluxes

The effectiveness of any flux under the limited treatment time of industrial processes is highly dependent on the rate of the reactions, which in part is determined by the viscosity $(\mu)$ and hence mass transport within the slag phase. Also, tapping of the slag and refractory erosion are strongly dependent on the viscosity. These aspects need to be quantified.

4- Melting rate

It is known that fluidity of the flux is important for good desulphurization and dephosphorization kinetics. Therefore, additional work could be conducted with different 
slag systems to examine the relationship between the desulphurization and dephosphorization rates and the melting rate of the slag.

\section{5- Characteristics of post-refining flux}

The chemical composition, mineralogy, microstructure (phases and their segregation), and leaching behavior of the constituents are of interest for determining the fate of the slag after its use in hot metal treatment. The information is essential in order to determine potential applications (e.g. cement feedstock, construction material, etc) or safe disposal strategies for the material. 


\section{Appendices}

\section{Appendix 1: Inductively coupled plasma (ICP)}

Inductively Coupled Plasma Optical Emission Spectroscopy ICP-OES is one of the common methods for analysis of trace elements and impurities in a variety of different sample materials. With this technique, an aqueous sample is converted to aerosol using a nebulizer and injected into to the inductively coupled plasma which sustains a temperature of approximately (8000$10000 \mathrm{~K}$ ), so the sample mist reaching the plasma is quickly vaporized. The plasma source dissociates the sample into its constituent atoms and promoting them to excited states. The atoms emit photons of characteristic wavelength while returning to their original state.

These emissions are separated based on their intensities and wavelength and a spectrometer records the light and quantification is achieved by comparing the intensity of emission from an unknown sample with that of a standard sample. Thus the wavelength of the photons can be used to identify the elements from which they originated. Up to 70 elements can be determined simultaneously in a single analysis. Even though, inter element interferences are possible if the wavelength of the element of interest is near the wavelength of another element. The internal standard such as yttrium (Y) is most widely used to manage interferences in ICP.

\section{A1 Sample Preparation}

The ICP-OES samples require acid digestion for the most analysis. The solid sample is dissolved in the appropriate medium and injected into the instrument.

\section{A1.1 Carbon saturated iron digestion}

A 0.15 gram sample of the carbon saturated iron was digested in a glass beaker with $15 \mathrm{ml}$ of concentrated nitric acid $\left(\mathrm{HNO}_{3}, 70 \mathrm{wt} \%\right)$ and deionized water in the volume ratio of 2:1 respectively.

The glass beaker and content was heated to a temperature of $60-80{ }^{\circ} \mathrm{C}$ for half an hour. The digested solution was filtered through a filter. The filtrate was made up to the $50 \mathrm{ml}$ into a volumetric flask by adding deionized water. A $50 \mathrm{ml}$ blank sample was also prepared with the exact same ratios of the acids used for digestion. 


\section{A1.2 Flux sample digestion}

Aqua regia (royal water) or nitro-hydrochloric acid was used for red mud/flux digestion. The mixture is prepared by mixing concentrated nitric acid and hydrochloric acid in a volume ratio of 1:3. A 0.1 gram of flux sample was digested into $20 \mathrm{ml}$ of the acid mixture. The digestion was carried out at $90{ }^{\circ} \mathrm{C}$ for 60 minutes. The solution was filtered and diluted to volume with deionized water. 


\section{Appendix 2: Raw materials for research}

The chemicals used and their purity grades for desulphurization, dephosphorization and melting behaviour experiments are shown in Table A2-1, Table A2-2 and Table A-2-4 respectively. Lime, alumina, titania, silica and dicalcium phosphate were calcined at $800{ }^{\circ} \mathrm{C}$ for $3 \mathrm{~h}$ to remove any moisture.

Table A2- 1: Characteristics of the materials used for desulphurization experiments

\begin{tabular}{|c|c|c|}
\hline Material & Purity, wt $\%$ & Supplier \\
\hline Red mud $(\mathrm{RM})$ & NA & Alcoa Co. \\
\hline Calcium oxide $(\mathrm{CaO})$ & 99.98 & Alfa Aesar \\
\hline Silicon oxide $\left(\mathrm{SiO}_{2}\right)$ & 99.95 & Alfa Aesar \\
\hline Aluminum oxide $\left(\mathrm{Al}_{2} \mathrm{O}_{3}\right)$ & 99.98 & Alfa Aesar \\
\hline Titanium oxide $\left(\mathrm{TiO}_{2}\right)$ & 99.95 & Sigma Aldrich \\
\hline Sodium carbonate $\left(\mathrm{Na}_{2} \mathrm{CO}_{3}\right)$ & 99.98 & Sigma Aldrich \\
\hline Ferrous sulphide $(\mathrm{FeS})$ & 99.95 & Sigma Aldrich \\
\hline Electrolytic iron & 99.90 & Allied Metals Corporation \\
\hline Graphite powder & 99.99 & GraphiteStore.com \\
\hline Purified graphite rod & 99.99 & GraphiteStore.com \\
\hline Alumina tube & 99.80 & McDaniel Refractory Co \\
\hline Carbon monoxide $(\mathrm{CO})$ & 99.99 & Linde \\
\hline
\end{tabular}


Table A2- 2: Characteristics of the materials used in dephosphorization experiments

\begin{tabular}{|c|c|c|}
\hline Material & Purity wt $\%$ & Supplier \\
\hline Calcium oxide $(\mathrm{CaO})$ & 99.98 & Alfa Aesar \\
\hline Silicon oxide $\left(\mathrm{SiO}_{2}\right)$ & 99.95 & Alfa Aesar \\
\hline Aluminum oxide $\left(\mathrm{Al}_{2} \mathrm{O}_{3}\right)$ & 99.98 & Alfa Aesar \\
\hline Titanium oxide $\left(\mathrm{TiO}_{2}\right)$ & 99.95 & Sigma Aldrich \\
\hline Sodium carbonate $\left(\mathrm{Na}_{2} \mathrm{CO}_{3}\right)$ & 99.98 & Sigma Aldrich \\
\hline Iron (III) oxide (Fe2O3) & 99.98 & Sigma Aldrich \\
\hline Fe powder $(\mathrm{Fe})$ & 99.99 & Alfa Aesar \\
\hline Dicalcium phosphate $\left(\mathrm{CaHPO}_{4}\right)$ & 99.98 & Sigma Aldrich \\
\hline High purity iron foil thickness $100 \mu \mathrm{m}$ & $\geq 99.98$ & Sigma Aldrich \\
\hline Armco iron & 99.95 & Goodfellow \\
\hline Alumina tube & 99.80 & McDaniel Refractory Co \\
\hline Zirconium dioxide rod & 99.20 & Goodfellow \\
\hline Argon gas & 99.99 & Linde \\
\hline
\end{tabular}

Table A2- 3: Composition of Armco iron and iron foil

\begin{tabular}{|c|c|c|c|c|c|c|c|}
\hline Material & $\mathrm{C}$ & $\mathrm{Mn}$ & $\mathrm{Si}$ & $\mathrm{Cu}$ & $\mathrm{P}$ & $\mathrm{S}$ & $\mathrm{Fe}$ \\
\hline Armco iron & 0.013 & 0.009 & 0.009 & 0.01 & 0.006 & 0.005 & 99.95 \\
\hline High purity iron foil & 0.005 & 0.006 & 0.001 & 0.001 & 0.002 & 0.005 & 99.98 \\
\hline
\end{tabular}


Table A2- 4: Characteristics of the materials used for the melting behavior experiments

\begin{tabular}{|c|c|c|}
\hline Material & Purity, $\%$ & Supplier \\
\hline Red mud & NA & Alcoa Co. \\
\hline Calcium oxide $(\mathrm{CaO})$ & 99.98 & Alfa Aesar \\
\hline Silicon oxide $\left(\mathrm{SiO}_{2}\right)$ & 99.95 & Alfa Aesar \\
\hline Aluminum oxide $\left(\mathrm{Al}_{2} \mathrm{O}_{3}\right)$ & 99.98 & Alfa Aesar \\
\hline Titanium oxide $\left(\mathrm{TiO}_{2}\right)$ & 99.95 & Sigma Aldrich \\
\hline Sodium carbonate $\left(\mathrm{Na}_{2} \mathrm{CO}_{3}\right)$ & 99.98 & Sigma Aldrich \\
\hline
\end{tabular}




\section{Appendix 3: Scanning electron microscopy of red mud}

The Hitachi S2500 scanning electron microscope was used to characterize the particle morphologies of the red mud sample.

The scanning electron microscopy image Figure A3-1(A) shows red mud powder is constituted by agglomerates which formed by very fine particles of different sizes. The presence of agglomerated particles can be seen in Figure A3-1(B). The results indicate that the red mud particles are polygonal in shape and $90 \%$ of the particles are $55 \mu \mathrm{m}$ or smaller.

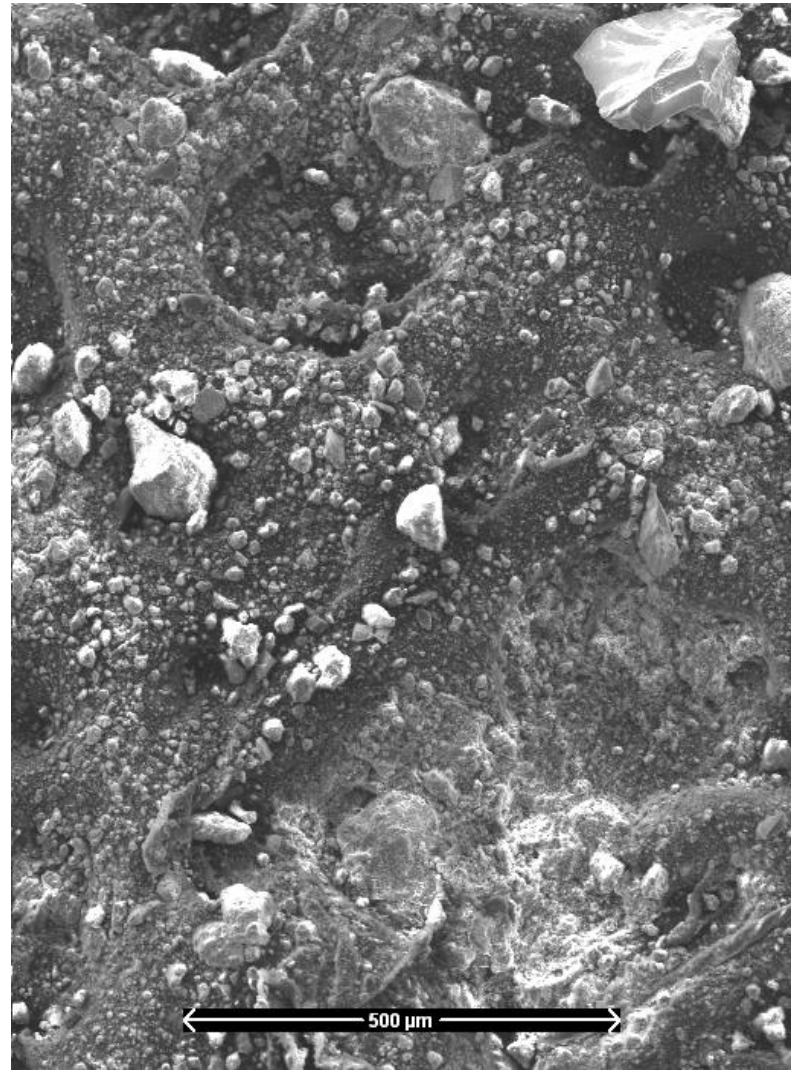

(A)

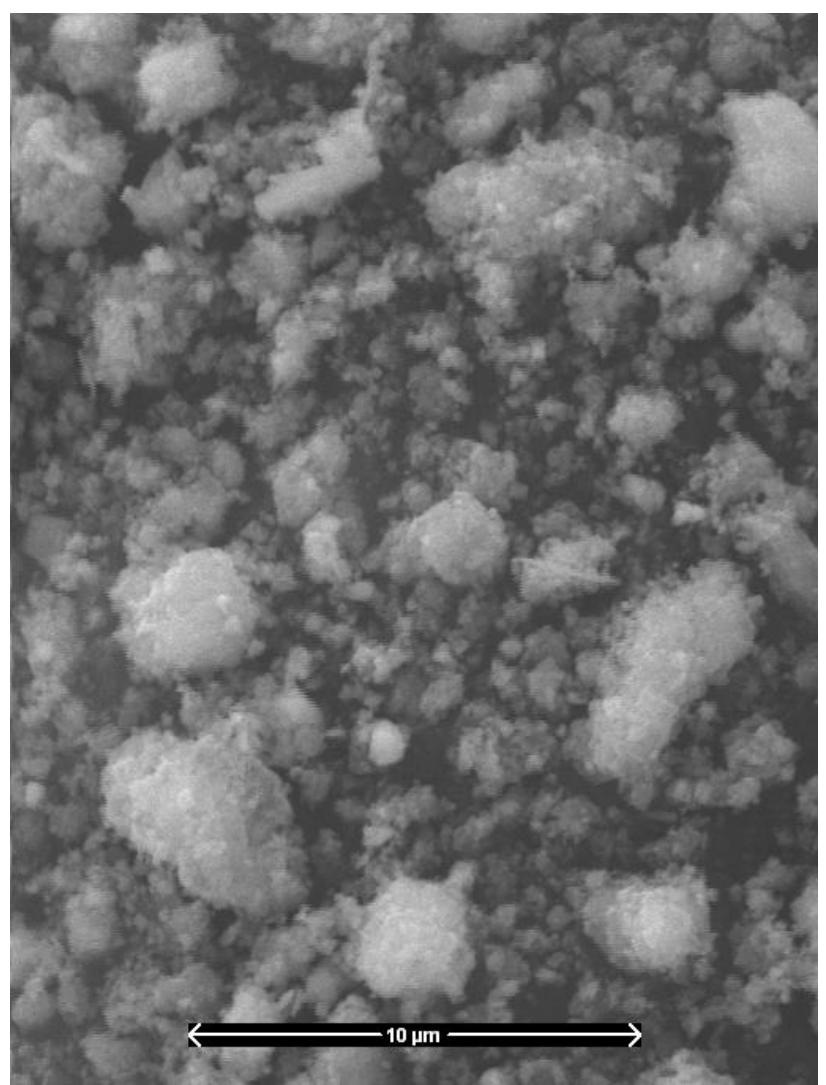

(B)

Figure A3- 1: Scanning electron microscopy of red mud 


\section{Appendix 4: XRD results of red mud fluxes}

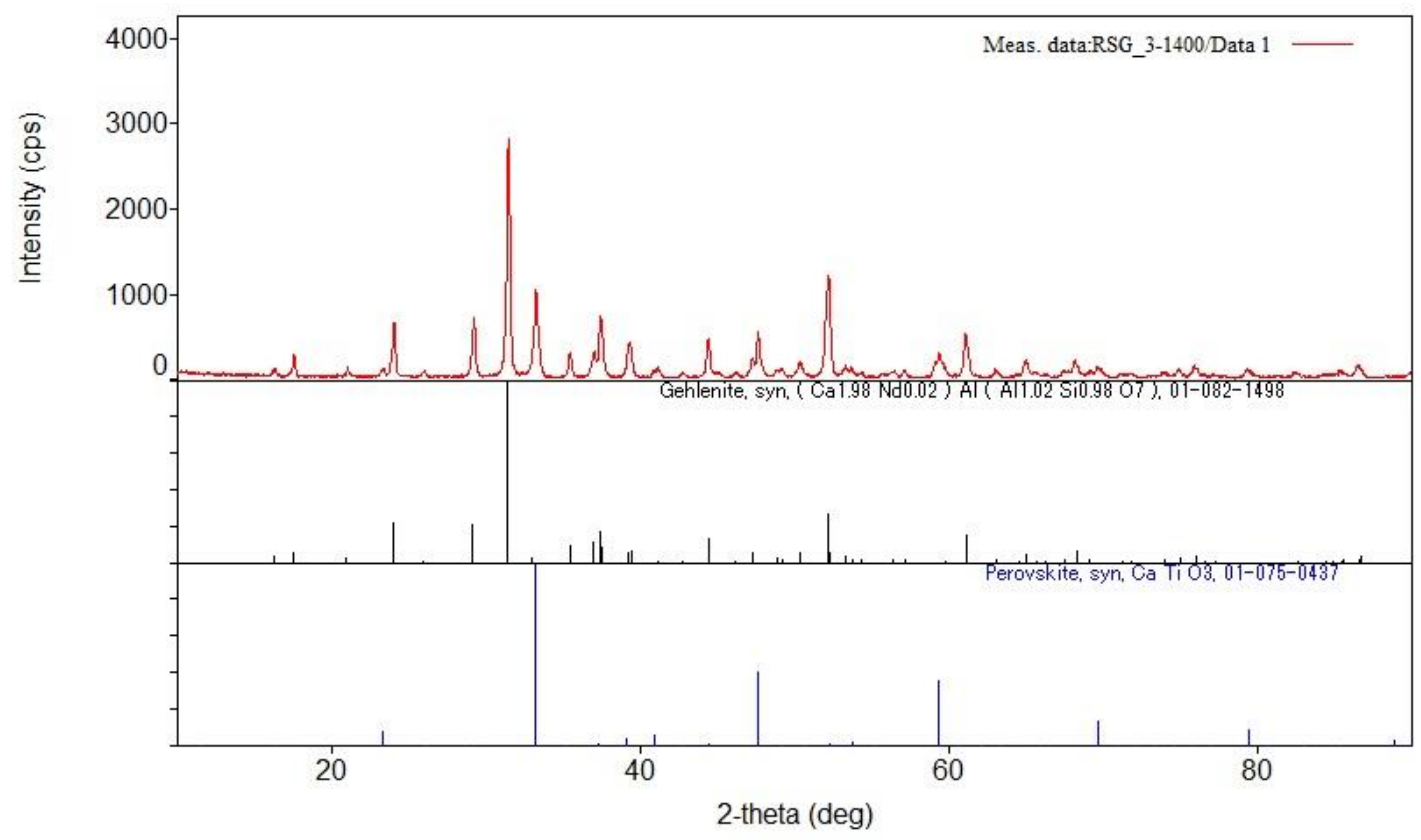

Figure A4- 2: XRD pattern of RMF3

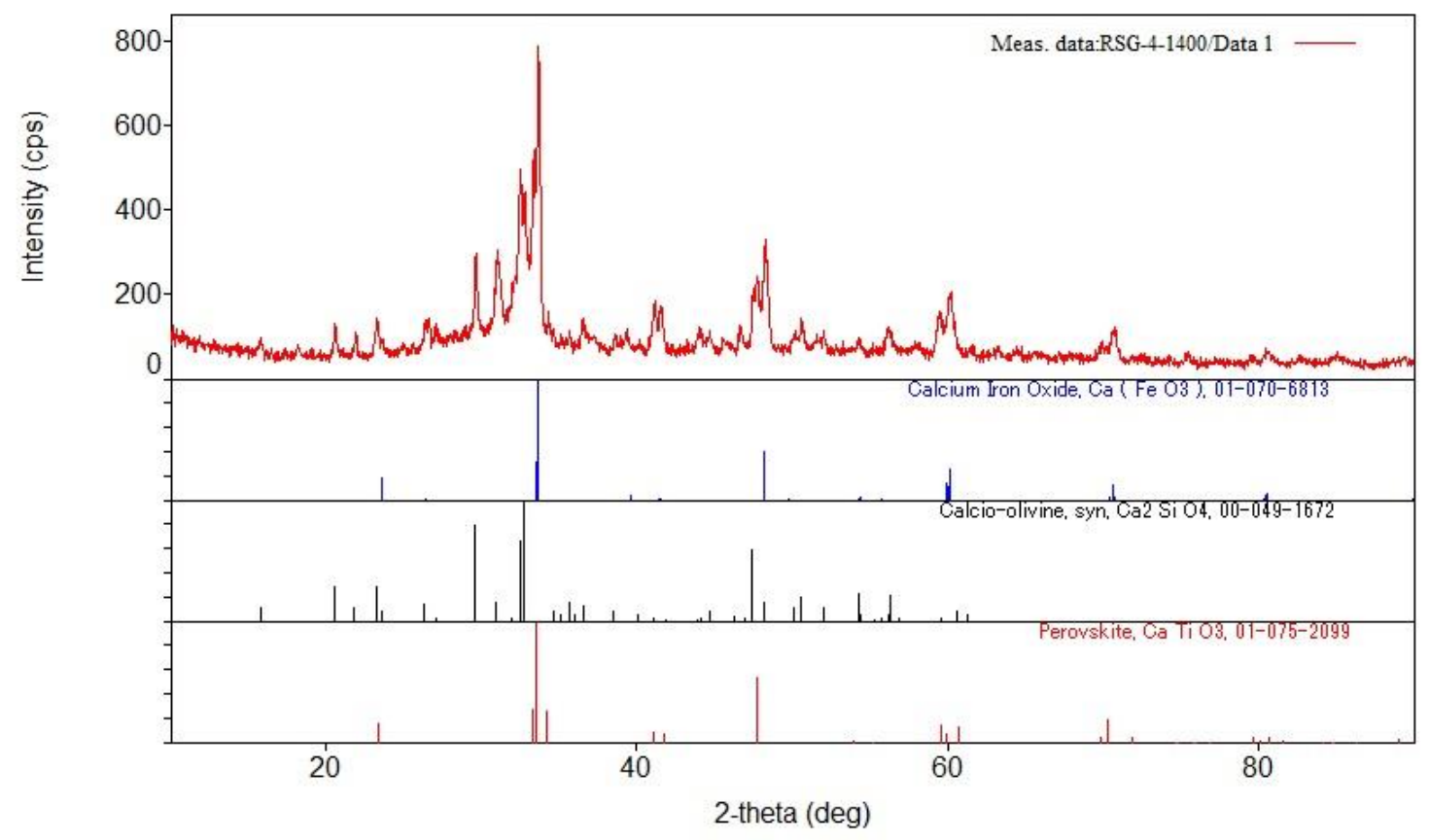

Figure A4- 3: XRD pattern of RMF4 


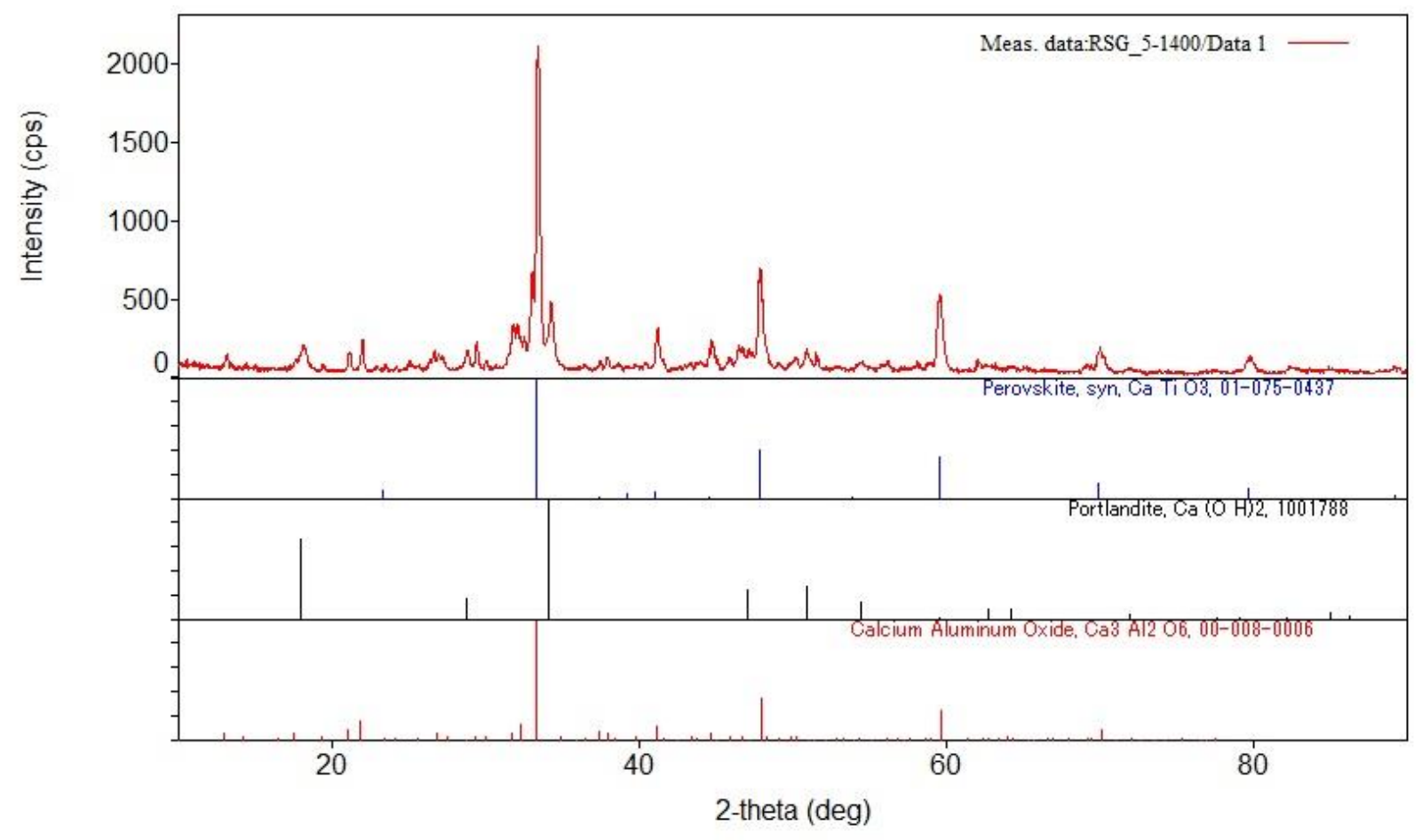

Figure A4- 4: XRD pattern of RMF5

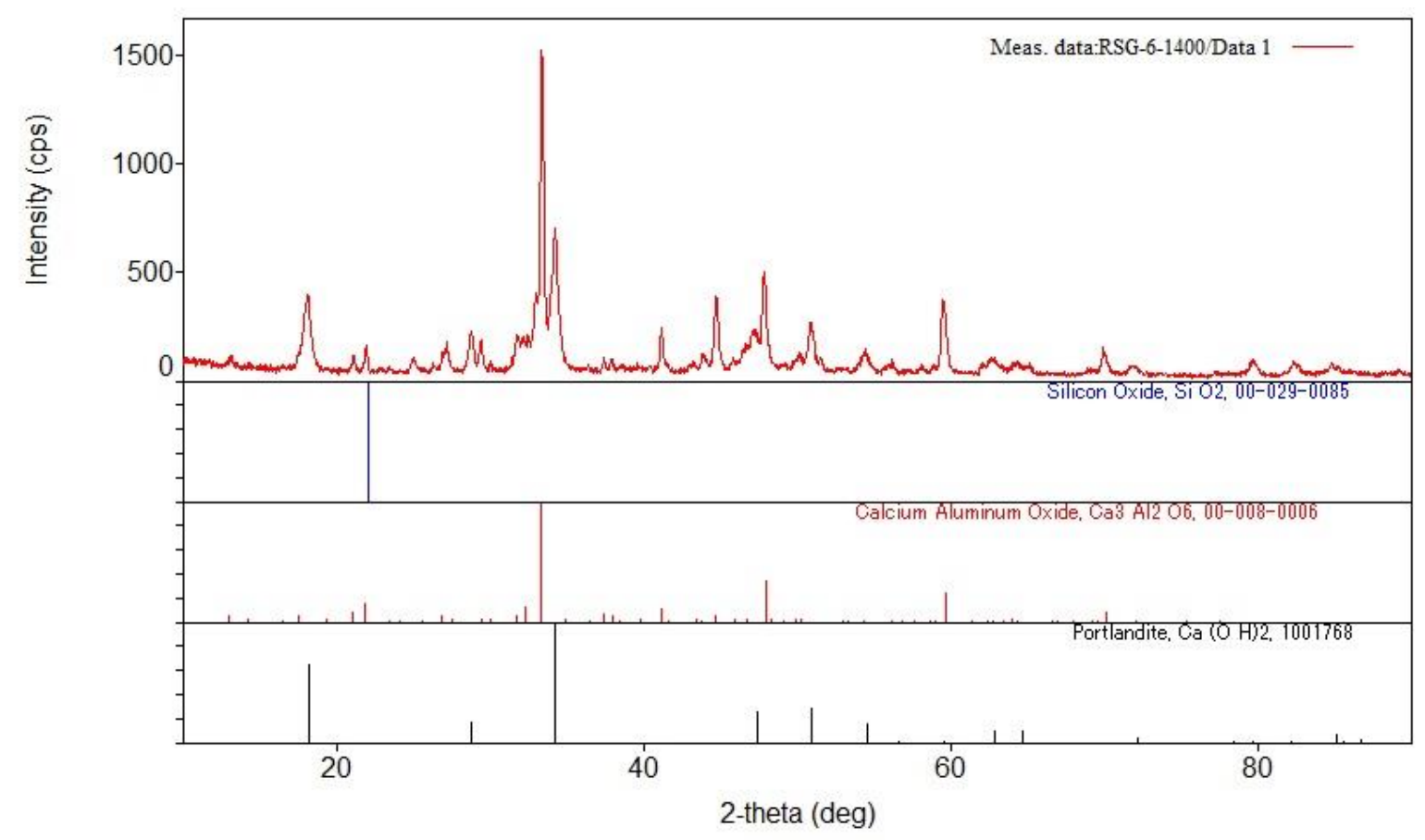

Figure A4- 5: XRD pattern of RMF6 


\section{Appendix 5: Calculation of phosphorus partition ratio}

Spencer and Kubaschewski [115] stated the chemical potential of phosphorus in $\mathbf{F e}-\boldsymbol{\gamma}$ relative to a standard state of superheated liquid phosphorus can be defined as follow:

$$
\mu_{\mathrm{P}}^{\gamma}=\mu_{\mathrm{P}(\mathrm{l})}^{\circ}+\mathrm{RT} \ln \gamma_{\mathrm{P}}^{\gamma} \cdot \mathrm{X}_{\mathrm{P}}^{\gamma}
$$

where:

$$
\mathrm{RT} \ln \gamma_{\mathrm{P}}^{\gamma}=-128519+32.67 \mathrm{~T} \quad\left(1184 \text { to } 1665 \mathrm{~K}, \mathrm{~J} \cdot \mathrm{mol}^{-1}\right)
$$

On the other hand, the chemical potential of phosphorus in carbon saturated liquid iron relative to a standard state of $1 \%$ solution of phosphorus in liquid iron can be determined [116]

$$
\begin{gathered}
\mu_{\mathrm{P}}^{\mathrm{Fe}-\mathrm{C}}=\mu_{\mathrm{P}(1 \%)}^{\circ}+\mathrm{RT} \ln \gamma_{\mathrm{P}}^{\mathrm{Fe}-\mathrm{C}} \cdot \mathrm{X}_{\mathrm{P}}^{\mathrm{Fe}-\mathrm{C}} \\
\mu_{\mathrm{P}(1 \%)}^{\circ}=\left(\frac{1}{2}\right) \mu_{\mathrm{P} 2(\mathrm{~g})}^{\circ}-122172-19.25 \mathrm{~T} \quad \mathrm{~J} . \mathrm{mol}^{-1}
\end{gathered}
$$

By substituting Equation 4 into Equation 3:

$$
\mu_{\mathrm{P}}^{\mathrm{Fe}-\mathrm{C}}=\left(\frac{1}{2}\right) \mu_{\mathrm{P} 2(\mathrm{~g})}^{\circ}-122172-19.25 \mathrm{~T}+\mathrm{RT} \ln \gamma_{\mathrm{P}}^{\mathrm{Fe}-\mathrm{C}} \cdot \mathrm{X}_{\mathrm{P}}^{\mathrm{Fe}-\mathrm{C}} \quad \mathrm{J} \cdot \mathrm{mol}^{-1}
$$

Barin et al. [117] suggested the term $\mu_{\mathrm{P}(\mathrm{l})}^{\circ}$ in Equations 1 and 3 and $\mu_{\mathrm{P} 2(\mathrm{~g})}^{\circ}$ in Equation 7 can be rewritten relative to a standard state of white phosphorus at $298.15 \mathrm{~K}$ as follows:

$$
\begin{array}{ccc}
\mu_{\mathrm{P}(\mathrm{l})}^{\circ}=-7238+133.30 \mathrm{~T}-26.33 \mathrm{TlnT} \quad \mathrm{J} . \mathrm{mol}^{-1} & 6 \\
\mu_{\mathrm{P} 2(\mathrm{~g})}^{\circ}=131428+27.75 \mathrm{~T}-39.96 \cdot 10^{-5} \mathrm{~T}^{2}+20.79 \cdot \frac{10^{4}}{\mathrm{~T}}-18.15 \mathrm{~T} \ln \mathrm{T} & \mathrm{J} . \mathrm{mol}^{-1} & 7
\end{array}
$$

The quotient of the phosphorus concentration in solid iron $(\mathbf{F e}-\boldsymbol{\gamma}$ ) and liquid $\mathrm{Fe}-\mathrm{C}$ (carbon saturated iron whereas $\mathrm{a}_{\mathrm{C}}=1$ ) can be explained in term of $\% \mathrm{P}$. The following relation is given for dilute solutions of phosphorus in iron:

$$
\mathrm{X}_{\mathrm{P}} \approx \frac{[\% \mathrm{P}] \cdot \mathrm{M}_{\mathrm{Fe}}}{\mathrm{M}_{\mathrm{p}} \cdot 100}
$$

Therefore when a solid iron has the same chemical potential for phosphorus as that of a carbon saturated iron the following quotients can be constructed by combining Equations 6 and 1and Equations7 with 5 as follow:

$$
\ln \frac{[\% \mathrm{P}]^{\mathrm{Fe}-\gamma}}{[\% \mathrm{P}]^{\mathrm{Fe}-\mathrm{C}}}=-69.43-10.05 \cdot 10^{-5} \mathrm{~T}+\frac{39906}{\mathrm{~T}}+\frac{52320}{\mathrm{~T}^{2}}+4.12 \ln \mathrm{T}+\ln \gamma_{\mathrm{P}}^{\mathrm{Fe}-\mathrm{C}}
$$


Activity coefficient of phosphorus in carbon saturated iron at $1600{ }^{\circ} \mathrm{C}$ is given by [68]:

$$
\ln \gamma_{\mathrm{P}}^{\mathrm{Fe}-\mathrm{C}}=1.8+3.5 \mathrm{X}_{\mathrm{P}}
$$

In dilute solution while $X_{P} \rightarrow 0$ thus $\ln \gamma_{P}^{\mathrm{Fe}-\mathrm{C}}=1.8$

By considering the regular solution model the value of the activity coefficient cab be corrected to $1300^{\circ} \mathrm{C}$ instead of $1600^{\circ} \mathrm{C}$ as follow :

$$
\ln \gamma_{\mathrm{P}}^{\mathrm{Fe}-\mathrm{C}}=1.8 \times \frac{1873}{1573}=2.14
$$

Consequently, Im et al. [107] reported that in dilute solution of phosphorus at $1300^{\circ} \mathrm{C}$ :

$\frac{[\% \mathrm{P}]^{\gamma}}{[\% \mathrm{P}]^{\mathrm{Fe}-\mathrm{C}}}=0.413$ 


\section{Bibliography}

1. M. Grafe, G. Power and C. Klauber, "Review of bauxite residue alkalinity and associated chemistry", Commonwealth Scientific and Industrial Research Organization (CSIRO), Australian Government, 2009.

2. C. Wenzhong, T. Weiwei, and Z. Hong, "Bayer process and soda-lime sintering process of special diasporic bauxite with high silica", Light Metals 2010, TMS 2010 Annual Meeting and Exhibition, Seattle, WA, United states, 2010, pp.149-155.

3. A. Danaei, C. Ravindran, Y. D. Yang, M. Barati, and A. McLean, "Effects of lime additions on the sulphur distribution between red mud based fluxes and carbon saturated liquid iron, 4th International Symposium on High-Temperature Metallurgical Processing, TMS Annual Meeting \& Exhibition, San Antonio, Texas, USA, 2013, p. 213.

4. G. Power, M. Gräfe, and Craig Klauber. "Bauxite residue issues: I. Current management, disposal and storage practices" Hydrometallurgy, Vol. 108, No. 1, 2011, pp. 33-45.

5. K. Snars, and R. J. Gilkes, "Evaluation of bauxite residues (red muds) of different origins for environmental applications" Applied Clay Science, Vol. 46, No. 1, 2009, pp. 13-20.

6. J. N. Gordon, W. R. Pinnock, and M. M. Moore, "A preliminary investigation of strength development in Jamaican red mud composites", Cement and Concrete Composites, Vol. 18, No. 6, 1996, pp. 371-379.

7. P. Vachon, R. D. Tyagi, J. C. Auclair, and K. J. Wilkinson. "Chemical and biological leaching of aluminum from red mud", Environmental science \& technology, Vol. 28, No. 1, 1994, pp. 26-30.

8. V. M. Sglavo, et al., "Bauxite 'Red mud' in the ceramic industry. Part 2: production of clay-based ceramics" Journal of the European Ceramic Society, Vol. 20, No. 3, 2000, pp. 245-252.

9. W. Liu, J. Yang, and B. Xiao, Application of Bayer red mud for iron recovery and building material production from alumosilicate residues " Journal of Hazardous Materials, Vol. 161, No. 1, 2009, pp. 474-478. 
10. N. Zhang, H. Sun, X. Liu, and J. Zhang, "Early - age characteristics of red mud-coal gangue cementitious material. Journal of Hazardous Materials, Vol. 167, No. 1-3, 2009, pp. 927-932.

11. Y. Yang, P. Wu, G. Men, and A. McLean "Hot metal desulphurization using waste residues from the aluminum industry, High Temperature Materials and Processes, Vol. 31, No. 4-5, 2012, pp. 519-528.

12. V. Feigl, A. Anton, N. Uzigner, and K. Gruiz, "Red mud as a chemical stabilizer for soil contaminated with toxic metals", Water, Air and Soil Pollution, Vol. 223, No. 3, 2012, pp. 1237-1247.

13. Y. Liu, and L. Luo, " Effects of granulated red mud on Lead-Zinc waste soil remediation and leeks growth", International Conference on Computer Distributed Control and Intelligent Environmental Monitoring, Changsha, Hunan China, IEEE, 2011, pp. 1202 1206.

14. C. Klauber, M. Graf, and G. Power, "Review of bauxite residue 'Re-use' options", Australian Government, Department of Resources, Energy and Tourism, 2009. p. 1-77.

15. P.E. Tsakiridis, S. Agatzini-Leonardou, and P. Oustadakis, " Red mud addition in the raw meal for the production of portland cement clinker", Journal of Hazardous Materials, Vol. 116, No. 1-2, 2004, pp. 103-110.

16. M. Singh, S. N. Upadhayay, and P. M. Prasad, " Preparation of iron rich cements using red mud", Cement and Concrete Research, Vol. 27, No. 7, 1997, pp. 1037-1046.

17. I. Vangelatos, G. N. Angelopoulos, and D. Boufounos, "Utilization of ferroalumina as raw material in the production of ordinary portland cement", Journal of Hazardous Materials, Vol. 168, No. 1, 2009, pp. 473-478

18. T. Kavas, "Use of boron waste as a fluxing agent in production of red mud brick", Building and Environment, Vol. 41, No. 12, 2006, pp. 1779-1783. 
19. J. Yang, D. Zhang, J. Hou, B. He, and B. Xiao, "Preparation of glass-ceramics from red mud in the aluminum industries", Ceramics International, Vol. 34, No. 1, 2008, pp. 125 130.

20. M. Erol, S. Küçükbayrak, and A. Ersoy-Mericboyu, "Production of glass-ceramics obtained from industrial wastes by means of controlled nucleation and crystallization", Chemical Engineering Journal, Vol. 132, No. 1-3,2007, pp. 335-343.

21. F. Peng, K.M. Liang, H. Shao, and A.M. Hu, "Nano-crystal glass-ceramics obtained by crystallization of vitrified red mud", Chemosphere, Vol. 59, No. 6, 2005, pp. 899-903.

22. H. Yang, C. Chen, L. Pan, H. Lu, H. Sun, and X. Hu, "Preparation of double-layer glass-ceramic/ceramic tile from bauxite tailings and red mud", Journal of the European Ceramic Society, Vol. 29, No. 10, 2009, pp. 1887-1894.

23. E. Erçagğ, and R Apak, "Furnace smelting and extractive metallurgy of red mud: Recovery of $\mathrm{TiO}_{2}, \mathrm{Al}_{2} \mathrm{O}_{3}$ and pig iron", Journal of Chemical Technology and Biotechnology, Vol. 70, No. 3, 1997, pp. 241-246.

24. E. Şayan and M. Bayramoğlu, "Statistical modelling of sulphuric acid leaching of $\mathrm{TiO}_{2}$, $\mathrm{Fe}_{2} \mathrm{O}_{3}$ and $\mathrm{Al}_{2} \mathrm{O}_{3}$ from red mud", Process Safety and Environmental Protection, Vol. 79, No. 5, pp. 291-296.

25. Q. Xiang, X. Liang, M. E. Schlesinger, and J.L. Watson, "Low temperature reduction of ferric iron in red mud", Light Metals: Proceedings of Sessions, TMS Annual Meeting, Warrendale, Pennsylvania, New Orleans, LA, 2001, pp. 157-162.

26. W. Huang, S. Wang, Z. Zhu, L. Li, X. Yao, V. Rudolph, and F. Haghseresht, "Phosphate removal from wastewater using red mud" Journal of Hazardous Materials, Vol. 158, No. 1, 2008, pp. 35-42.

27. W. Liu, J. Yang, and B. Xiao, "Review on treatment and utilization of bauxite residues in China", International Journal of Mineral Processing, Vol. 93, No. 3-4, 2009, pp. 220231. 
28. C. Namasivayam and D. J. S. E, Arasi, "Removal of congo red from wastewater by adsorption onto waste red mud", Chemosphere, Vol. 34, No. 2, 1997, pp. 401-417.

29. E. E. Shannon and K. I. Verghese, "Utilization of aluminized red mud solid (ARMS) for phosphorus removal", Water Pollution Control Federation, Vol. 48, No. 8, 1976, pp. 1948-1954.

30. Metals Handbook Vol. 15, Casting, American Society for Metals, Materials Park, Ohio, 1988.

31. E. T. Turkdogan, "Fundamentals of steelmaking", The Institute of Materials, London, 1996.

32. S. Basu, S. Seetharaman, and A.K. Lahiri, "Thermodynamics of phosphorus and sulphur removal during basic oxygen steelmaking”, Steel Research International, Vol. 81, No. 11, 2010, pp. 932-939.

33. Britannica, Encyclopædia. "Encyclopædia Britannica Online. Encyclopædia Britannica, 2011." Web. Apr 6, 2011.

34. Slag Atlas, Edited by VDEh, Verlag Stahleisen GmbH, 2nd edition, 1995.

35. T. Nakamura, T. Yokoyama, and J. M. Toguri, "Limitations in the metallurgical application of optical basicity”, ISIJ International, Vol. 33, No. 1, 1993, pp. 204-209.

36. J.A. Duffy and M. D. Ingram, "An interpretation of glass chemistry in terms of the optical basicity concept", Journal of Non-Crystalline Solids, Vol. 21, No. 3, 1976, pp. 373-410.

37. J.A. Duffy, M. D. Ingram and I. D. Sommerville, “Acid/Basic properties of molten oxides and metallurgical slags, J. Chem. Soc. Faraday Trans., Vol. 74, No. 6, 1978, pp. 14101419. 
38. T. Nakamura, Y. Ueda, and F. Noguchi, "The characterization of slags using photoacoustic spectroscopy", Journal of the Japan Institue of Metals, Vol. 48, No. 4, 1984, pp. 391-396.

39. T. Nakamura, Y. Ueda, and J. M. Toguri, "Development of the optical basicity”, Journal of the Japan Institute of Metals, Vol. 50, No. 5, 1986, pp. 456-461.

40. I. D. Sommerville and Y. Yang, "Basicity of metallurgical slags", AusIMM Proceedings (Australia), Vol. 306, No. 1, 2001, pp. 71-77.

41. D. J. Sosinsky and I. D. Sommerville, "Composition and temperature dependence of the sulphide capacity of metallurgical slags", Metall. Trans. B, Vol. 17B, 1986, pp. 331337.

42. K. Karsrud, "Alkali capacities of synthetic blast furnace slags at $1500^{\circ} \mathrm{C}$ ", Scandinavian J. of Metallurgy, Vol.13, 1984, pp. 98-106.

43. A. Bergman, "A new model on $\mathrm{K} 2 \mathrm{O}$ solubility in blast-furnace slags", Steel Research, Vol. 60, 1989, pp. 383-386

44. Y. Yang, I. D. Sommerville and A. McLean, "Some fundamental considerations pertaining to oxide melt interactions and their influence on steel quality", Transactions of the Indian Institute of Metals, Vol. 59, No. 5, 2006, pp. 655-669.

45. F. D. Richardson, "Physical chemistry of metals in metallurgy", Academic press, London, 1974.

46. C. J. B. Fincham and F. D. Richardson, "The behaviour of sulphur in silicate and aluminate melts", Proceedings of the Royal Society of London. Series A, Mathematical and Physical Sciences, Vol. 223, No. 1152, 1954, pp. 40 - 62.

47. A. Shankar, M. Görnerup, S. Seetharaman, and A. K. Lahiri, "Sulphide capacity of high alumina blast furnace slags", Metallurgical and Materials Transactions B, Vol. 37, No. 6, 2006, pp. 941-947. 
48. M. M. Nzotta, D. Sichen, and S. Seetharaman, "Sulphide capacities in some multi component slag systems”, ISIJ International, Vol.38, No. 11, 1998, pp. 1170-1179.

49. Y. Taniguchi, N. Sano, and S. Seetharaman, "Sulphide capacities of $\mathrm{CaO}-\mathrm{Al}_{2} \mathrm{O}_{3}-\mathrm{SiO}_{2}$ $\mathrm{MgO}-\mathrm{MnO}$ slags in the temperature range 1673-1773 K”, ISIJ International, Vol. 49, No. 2, 2009. pp. 156-163.

50. H. Hayakawa, M. H. K.Ohnuki, T. Sawai and M. Iwase, "Sulphide capacities of CaO$\mathrm{SiO}_{2}-\mathrm{Al}_{2} \mathrm{O}_{3}-\mathrm{MgO}$ slags", Steel Research International, Vol.77, No. 1, 2006, pp. 14-20.

51. I. D. Sommerville and D. J. Sosinsky, "The application of the optical basicity concept to metallurgical slags", Second International Symposium on Metallurgical Slags and Fluxes, The Metallurgical Society, AIME, Warrendale, PA 1015, 1984, pp. 119-23.

52. Y. Taniguchi, N. Sano, and $\mathrm{S}$. Seetharaman, "Sulphide capacities of $\mathrm{CaO}-\mathrm{Al}_{2} \mathrm{O}_{3}-\mathrm{SiO}_{2-}$ MgO-MnO slags in the temperature range 1673-1773 K”, ISIJ International, Vol. 49, 2009, pp. 156-163.

53. R.W. Young, J. A. Duffy, G. J. Hassall, and Z. Xu, "Use of optical basicity concept for determining phosphorus and sulphur slag-metal partitions", Ironmaking Steelmaking, Vol. 19, No. 3, 1992, pp. 201-219.

54. R. Inoue and H. Suito, "Sulphur distribution between carbon-saturated iron melt and $\mathrm{Na}_{2} \mathrm{O}-\mathrm{SiO}_{2}$ slags", Transactions of the Iron and Steel Institute of Japan, Vol. 22, No. 7, 1982, pp. 514-523.

55. S. Nagashima, and T. Katsura, "The solubility of sulphur in $\mathrm{Na}_{2} \mathrm{OSiO}_{2}$ melts under various oxygen partial pressures at $1100^{\circ} \mathrm{C}, 1250^{\circ} \mathrm{C}$ and $1300^{\circ} \mathrm{C}$ ", Bull. Chem. Soc. Jpn, Vol. 46, 1973, pp. 3099-3103.

56. A. H. Chan and R. J. Fruehan, "The sulphur partition ratio and the sulphide capacity of $\mathrm{Na}_{2} \mathrm{O}-\mathrm{SiO}_{2}$ Slags at $1200^{\circ} \mathrm{C}$ ", Metallurgical and Materials Transactions B, Vol. 17, No. 3, 1986, pp.491-496. 
57. K. Kunisada and H. Iwai, "Effect of $\mathrm{Na}_{2} \mathrm{O}$ in phosphorus distribution between liquid iron and CaO-based slags", Transactions of the Iron and Steel Institute of Japan, Vol. 27, No. 4, 1987, pp. 263-269.

58. A. M. Cameron, J. Cook and P. Grieveson, "Some problems of sulphur reaction with aluminate melts", International Symposium on the Physical Chemistry of Iron and Steelmaking, CIM, Toronto, 1982, pp. 1.3-1.17.

59. A. H. Chan and R. J. Fruehan, "The sulphur partition ratio with $\mathrm{Fe}$-C melts and the sulphide capacity of $\mathrm{CaO}-\mathrm{SiO}_{2}-\mathrm{Na}_{2} \mathrm{O}-\left(\mathrm{Al}_{2} \mathrm{O}_{3}\right)$ slags", Metallurgical and Materials Transactions B, Vol. 20, No. 1, 1989, pp. 71-76.

60. P.T. Carter and T.G. Macfarlane, "Thermodynamics of slag systems, Part I - The thermodynamic properties of $\mathrm{CaO}-\mathrm{Al}_{2} \mathrm{O}_{3}$ slags", Journal of the Iron and Steel Institute, Vol. 185, 1957, pp. 54-66.

61. R.A. Sharma and F.D. Richardson, “Activities in lime-alumina melts”, Journal of the Iron and Steel Institute, Vol. 198, 1961, pp. 386-390.

62. G.J.W. Kor and F.D. Richardson, "Sulphur in lime-alumina mixtures", Journal of the Iron and Steel Institute, Vol. 206, 1968, pp. 700-704.

63. J. Cameron, T.B. Gibbons and J. Taylor, "Calcium sulphide solubilities and lime activities in the lime-alumina-silica system", Journal of the Iron and Steel Institute, Vol. 204, 1966, pp. 1223-1228.

64. Y. Yang, A. McLean, I. D. Sommerville, and A. R. McKague, "Study on phosphate and

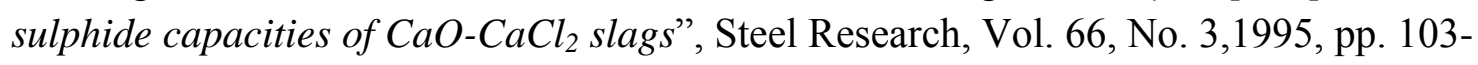
109.

65. C. Wagner, "The concept of the basicity of slags", Metallurgical and Materials Transactions B, Vol. 6, No. 3, 1975, pp. 405-409.

66. E T. Turkdogan, "Physical chemistry of high temperature technology”, 1980, New York, Academic Press. 
67. W. H. Van Niekerk and R.J. Dippenaar, "Phosphorus distribution between carbonsaturated iron at $1350^{\circ} \mathrm{C}$ and lime-based slags containing $\mathrm{Na}_{2} \mathrm{O}$ and $\mathrm{CaF}_{2}$ ", Metallurgical and Materials Transactions B, Vol. 29, No. 1, 1998, pp. 147-153.

68. H. G. Hadrys, M. G. Frohberg and J. F. Elliott, "Activities in the liquid Fe-Cr-C (sat), Fe$P$-C (sat), and $\mathrm{Fe}-\mathrm{Cr}-\mathrm{P}$ systems at $1600^{\circ} \mathrm{C}$ ', Metallurgical and Materials Transactions B, Vol. 1, No. 7, 1970, pp. 1867-1874.

69. D. R. Gaskell, "On the correlation between the distribution of phosphorus between slag and metal and the theoretical optical basicity of the slag", Transactions of the Iron and Steel Institute of Japan, Vol. 22, No. 12, 1982, pp. 997-1000.

70. H. Suito, R. INOUE and M. Takada, "Phosphorus distribution between Liquid Iron and $\mathrm{MgO}$ saturated slags of the system $\mathrm{CaO}-\mathrm{MgO}-\mathrm{FeOx}-\mathrm{SiO}_{2}$ ”, Transactions of the Iron and Steel Institute of Japan, Vol. 21, No. 4, 1981, pp. 250-259.

71. T. Mori, "On the phosphorus distribution between slag and metal”, Transactions of the Japan Institute of Metals, Vol. 25,No.11, 1984, pp. 761-771.

72. A. Bergman and A. Gustafsson, "On the relation between optical basicity and phosphorus capacity of complex slags", Steel Research, Vol. 59, No. 7, 1988, pp. 281288.

73. A. McKague, A. McLean and I.D. Sommerville, "The dephosphorization of carbon saturated iron using lime calcium halide slags", Process Technology Proceedings, Washington, D.C., Vol. 6, 1986, pp. 493497.

74. W. R. Maddocks and E. T. Turkdogan, "The effect of sodium oxide additions to steelmaking slags. Part I. Use of soda to dephosphorize pig iron at $1400^{\circ} C^{\prime \prime}$, J. Iron and Steel Inst., London, Vol. 162. 1949, pp. 25-31.

75. J. J. Pak and R. J. Fruehan, "Dynamics of the hot metal dephosphorization with $\mathrm{Na}_{2} \mathrm{O}$ slags", Metallurgical Transactions B , Vol. 18, No. 4, 1987, pp 687-693. 
76. W. R. Maddocks and E. T. Turkdogan, "The Effect of Sodium Oxide Additions to Steelmaking Slags. Part I. use of soda to dephosphorize pig iron at 1400 C", J. Iron and Steel Inst., London, Vol. 162. 1949, pp. 249-264.

77. W. Oelsen, "The dephosphorization and desulphurization of high-carbon iron melts with the production of water- soluble, high phosphorus slags", Arch Eisenhuttenw, Vol. 36, No. 12, 1965, pp. 861-871.

78. R. Inoue and H. Suito, "Phosphorus distribution between soda- and lime-based fluxes and carbon-saturated iron melts", Tetsu-To-Hagane, Vol. 71, No. 2, 1985, pp. 212-219.

79. R. Inoue and H. Suito, "Dephosphorization of molten iron by sodium carbonate and sodium sulfate”, ISIJ International, Vol. 21, No. 8, 1981, pp. 545-553.

80. H. Suito, Hideaki, A. Ishizaka, R. Inoue, and Y. Takahashi, "Simultaneous dephosphorization and desulphurization of carbon-saturated iron by sodium carbonatesodium sulfate flux", Transactions of the Iron and Steel Institute of Japan, Vol. 21, No. 3, 1981, pp. 156-164.

81. J. J. Pak and R. J. Fruehan, "Soda slag system for hot metal dephosphorization", Metallurgical Transactions B, Vol. 17, No. 4, 1986, pp. 797-804.

82. J. Borode, "Phosphorus partition ratio and phosphate capacity of $\mathrm{Na}_{2} \mathrm{O}-\mathrm{SiO}_{2}$ at $1400{ }^{\circ} \mathrm{C}$ ”, Ironmaking \& Steelmaking, Vol. 25, No. 2, 1998, pp. 144-149.

83. K. Sasaki, "Dephosphorization of hot metal in the ladle", Tetsu-to-Hagane, Vol. 63, No. 12, 1977, pp. 1801-1808.

84. K. Iwasaki, N. Sano, and Y. Matsushita, "The distribution of phosphorus between hot metal and slag at hot metal temperatures", Tetsu-to-Hagane, Vol. 67, No. 3, 1981, pp. 536-540.

85. K. Ito and N. Sano, "Phosphorus distribution between CaO-containing slag and carbonsaturated iron at hot metal temperatures", Tetsu-To-Hagane (Journal of the Iron and Steel Institute of Japan), Vol. 69, No. 15, 1983, pp. 1747-1754. 
86. M. Muraki, H. Fukushima, and N. Sano, "Phosphorus distribution between $\mathrm{CaO}-\mathrm{CaF}_{2}$ $\mathrm{SiO}_{2}$ melts and carbon-saturated iron", Transactions of the Iron and Steel Institute of Japan, Vol. 25, No. 10, 1985, pp. 1025-1030.

87. A. Werme and P. A. Lundh, "Distribution of phosphorus between some $\mathrm{CaO}-\mathrm{FeO}-\mathrm{SiO}$ P2O5 (10\%) slags and C-saturated liquid iron at $1300{ }^{\circ} \mathrm{C}$ ”, Scandinavian Journal of Metallurgy, Vol. 16, 1987, pp. 33-41.

88. U. K. Mohanty and R. C. Behera " Fusion behaviour of synthetic aluminothermic ferrochrome slags", ISIJ international 43, No. 12, 2003, pp. 1875-1881.

89. H. Li, Y. Ninomiya, D. Zhongbing, and M. Zhang, "Application of the FactSage to predict the ash melting behavior in reducing conditions", Chinese Journal of Chemical Engineering, Vol 14, No. 6, 2006, pp.784-789.

90. En-Fa Wei, Y. Yang, C. Lin Feng, I. D. Sommerville, and A. McLean, "Effect of carbon properties on melting behavior of mold fluxes for continuous casting of steels", Journal of Iron and Steel Research International, Vol. 13, No. 2, 2006, pp. 22-26.

91. H. Chuang, W. Hwang, and S. Liu, "Effects of basicity and FeO content on the softening and melting temperatures of the $\mathrm{CaO}-\mathrm{SiO}_{2}-\mathrm{MgO}-\mathrm{Al}_{2} \mathrm{O}_{3}$ slag system", Materials Transactions, Vol. 50, No. 6, 2009, pp. 1448-1456.

92. A. P. Luz, S. Ribeiro, V. G. Domiciano, M. A. M. Brito, and V. C. Pandolfelli, "Slag melting temperature and contact angle on high carbon containing refractory substrates", Cerâmica, Vol. 57, No. 342, 2011, pp. 140-149.

93. B. Nandy, S. Chandra, D. Bhattacharjee, and D. Ghosh, "Assessment of blast furnace behaviour through softening-melting test”, Ironmaking \& Steelmaking, Vol. 33, No. 2, 2006, pp. 111-119.

94. R. V. Branion, and D. Dukelow, "Standardized testing of mold powder properties", In Steelmaking Conference Proceedings., Vol. 78, 1995, pp. 647-653.

95. German Standard, D.I.N., Testing of solid fuels-determination of fusibility of fuel ash, Berlin, Germany: Germany Institute for Standardization, 51730, 1984. 
96. Metals Handbook, Vol. 2, "Properties and selection: nonferrous alloys and specialpurpose materials", 10th ed., American Society for Metals: Materials Park, Ohio, 1992, p. 1111 and p. 1116.

97. J. M. Rivas Mercury, et al., "Thermal behavior and evolution of the mineral phases of Brazilian red mud", Journal of Thermal Analysis and Calorimetry, Vol. 104, No. 2, 2011, pp. 635-643.

98. J. Pascual, et al., "Thermal characterization of a spanish red mud", Journal of Thermal Analysis and Calorimetry, Vol. 96, No. 2, 2009, pp. 407-412.

99. A., Atasoy, "An investigation on characterization and thermal analysis of the Aughinish red mud", Journal of Thermal Analysis and Calorimetry, Vol. 81, No. 2, 2005, pp. 357361.

100. S. Mehta, A. Kalsotra and M. Murat, "A new approach to phase transformations in gibbsite: the role of the crystallinity", Thermochimica Acta, Vol. 205, 1992, pp. 191203.

101. V. M. Sglavo, et al., "Bauxite 'Red mud' in the ceramic industry. Part 2: production of clay-based ceramics" Journal of the European Ceramic Society, Vol. 20, No. 3, 2000, pp. 245-252.

102. A. Alp, and M. S. Goral, "The influence of soda additive on the thermal properties of red mud", Journal of Thermal Analysis and Calorimetry, Vol. 73, No. 1, 2003, pp. 201207.

103. G. I. D. Roach, E. Jamieson, N. Pearson, and A. B. Yu, "Effect of particle characteristics on the solids density of Bayer mud slurries", Essential Readings in Light Metals:

Alumina and Bauxite, Vol. 1, 2013, pp. 417-424.

104. G. K. Sigworth and J.F. Elliott, "The thermodynamicsof liquid dilute iron alloys" Metal Science, Vol. 6, 1974, pp. 298-310.

105. J. H. Park and P. C. Hee Rhee, "Ionic properties of oxygen in slag", Journal of NonCrystalline Solids, Vol. 282, 2001, pp. 7-14. 
106. F. D. Richardson and C. J. B. Fincham, "Sulfur in silicate and aluminate slags", Journal of the Iron and Steel Institute, Vol. 178, 1954, pp. 4-15.

107. J. Im, K. Morita, and N. Sano, "Phosphorus distribution ratios between $\mathrm{CaO}-\mathrm{SiO}_{2}-\mathrm{Fe}_{t} \mathrm{O}$ slags and carbon-saturated iron at 1573 K”, ISIJ International, Vol. 36, No. 5, 1996, pp. 517-521.

108. M. Y. Mohassab-Ahmed, H. Y. Sohn, and H. G. Kim, "Phosphorus Distribution between Liquid Iron and Magnesia-Saturated Slag in H2/H2O Atmosphere Relevant to a Novel Ironmaking Technology", Industrial \& Engineering Chemistry Research, Vol. 51, No. 20, 2012, pp. 7028-7034.

109. S. Basu, A.K. Lahiri, and S. Seetharaman, "Phosphorus partition between liquid steel and $\mathrm{CaO}-\mathrm{SiO}_{2}-\mathrm{FeO}_{X}-\mathrm{P}_{2} \mathrm{O}_{5}-\mathrm{MgO}$ slag containing 15 to $25 \mathrm{Pct} \mathrm{FeO”,} \mathrm{Metallurgical} \mathrm{and}$ Materials Transactions B, Vol.38, No. 4, 2007, pp. 623-630.

110. D. Jiang, "Effect of $\mathrm{Al}_{2} \mathrm{O}_{3}$ and $\mathrm{Na}_{2} \mathrm{O}$ on Dephosphorization of High Phosphorus Hot Metal", Journal of Iron and Steel Research, Vol. 25, No. 2, 2013, pp. 9-13.

111. S. R. Simeonov and N. Sano, "Phosphorus equilibrium distribution between slags containing $\mathrm{MnO}, \mathrm{BaO}$ and $\mathrm{Na}_{2} \mathrm{O}$ and carbon-saturated iron for hot metal pretreatment", Transactions of the Iron and Steel Institute of Japan, Vol. 25, 1985. pp. 1031-1035.

112. E. T. Turkdogan and J. Pearson, Activities of constituents of iron and steelmaking slags. J. Iron Steel Institute, Vol. 175, 1953, pp. 398-401.

113. C. W. Bale, et al., "FactSage thermochemical software and databases - recent developments", Calphad, vol. 33, pp. 295-311, 2009.

114. R. Scheel and W. Korte, "Effect of different flux powder compositions on continuous casting slags and casting practice”, Stahl Eisen, Vol. 107, No. 17, 1987, pp. 781-787.

115. P. Spencer and O. Kubaschewski, "Thermodynamic assessment of the iron-phosphorus system”, Arch. Eisenhuttenwes, Vol. 4, No. 5, 1978, pp. 225-228. 
116. J. B. Bookey, "The free energies of formation of tricalcium and tetracalcium phosphates", Journal of the Iron and Steel Institute, Vol. 172, No. 1, pp.61-66.

117. I. Barin, O. Knacke and O. Kubaschewski, "Thermodynamic Properties of Inorganic Substances (Supplement)", Verlag Stahleisen, Vol. 340, 1977. 